\title{
Decadal shoreline stability in Eastbourne, Wellington Harbour
}

\author{
David Olson
}

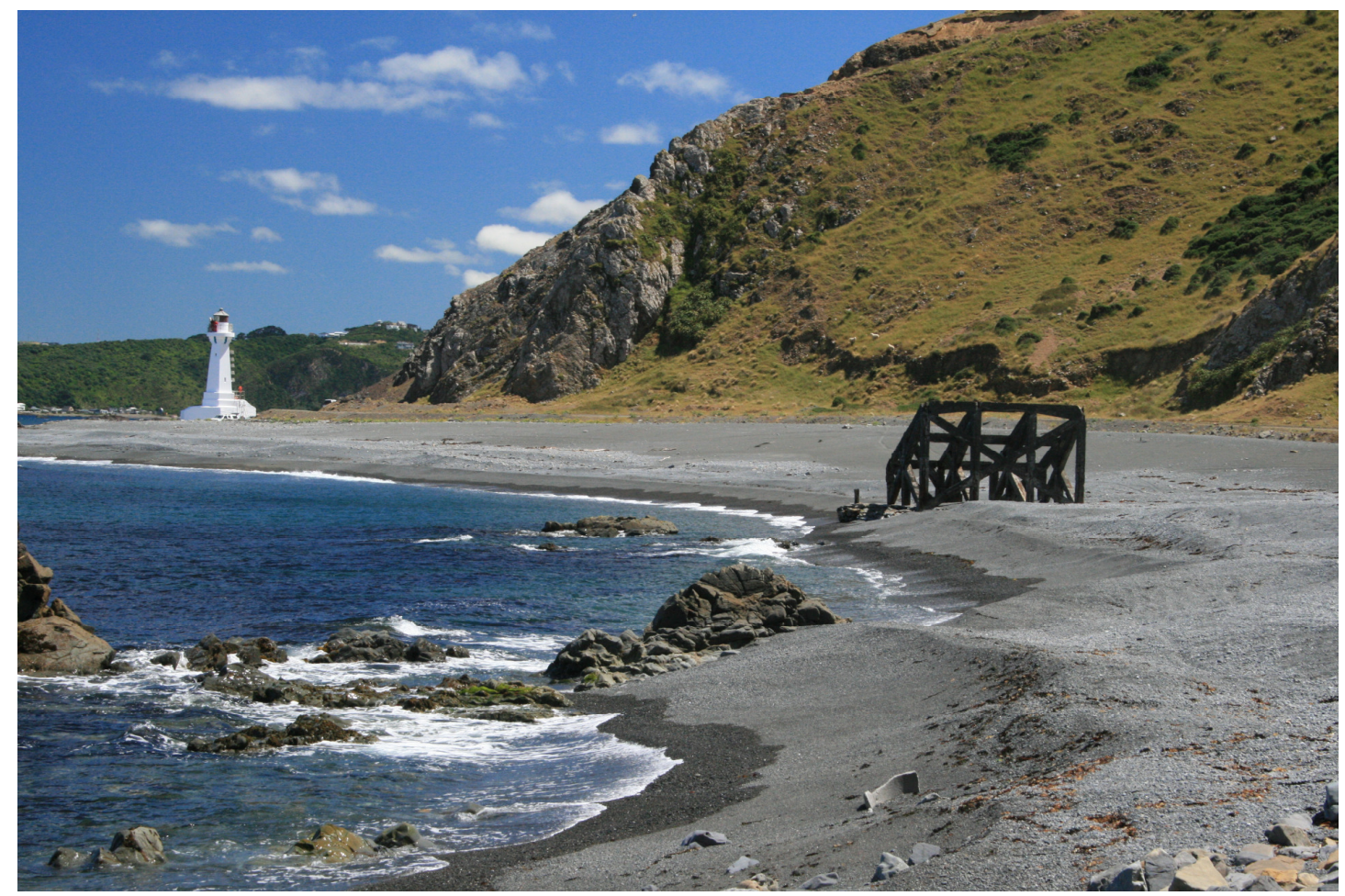

A thesis submitted to Victoria University of Wellington, in partial fulfillment of the requirements for the degree of Master of Science in Physical Geography

School of Geography, Environmental and Earth Sciences

Victoria University of Wellington

December 2009 


\begin{abstract}
Mixed Sand and Gravel (MSG) Beach research in recent decades has overwhelmingly focussed on open-oceanic environments, however, those found in fetch limited settings remain poorly understood. This thesis has examined spatial and temporal morphological change through such a system in Eastbourne, Wellington Harbour, New Zealand. This site has only recently prograded following several decades of erosion. This accretion has been the result of a northward migrating gravel front, which is introducing gravel sized sediment into the previously sandy system resulting in significant changes in beach morphology and volume.
\end{abstract}

The aim of this study is to quantify these spatial and temporal changes and to assess shoreline stability on a decadal timescale. Additionally it aims to ascertain whether the current progradation is a long term change to the system or the result of a short term sediment increase.

This assessment has been conducted in the form of topographic surveying, grain size and aerial photograph analysis. The topographic surveying and grain size analysis provides an accurate description of beach morphology. This is compared to the established MSG beach morphology models for the open coast, but operating on a smaller scale because of the lower energy fetch-limited environment of the study area. Aerial photograph analysis is used to show the longer term changes in beach width and the northern migration of the gravel fraction of the sediment supply regime.

The spatial analysis results show that the beach morphology is highly variable. In the embayments that are more exposed to oceanic swell waves beach profiles are broad and steep, and in the beaches in the northern sections of the coastline which are more sheltered from oceanic swell waves, profiles are flat and narrow. The temporal results show that the coastal accretion observed through the study area has been initially rapid, followed by sustained increased beach width.

These results suggest that the morphological variation on this coastline is part of a long term adjustment to a change in sediment supply, initiated by tectonic uplift and subsequently driven by longshore sediment transport. The observed mechanism of longshore transport has been suggested to be a function of sediment properties, relative wave energy and bathymetry/topography. The findings of this research are used to develop a conceptual model of shoreline evolution for the study area in response to changes that have occurred over the last 154 years. 


\section{Acknowledgements}

This thesis has certainly been a learning experience on many levels. At times it has been extremely taxing, testing the limits of my patience, and at times it has been thoroughly rewarding. The one constant however, is that it has been a challenge, and a challenge that would not have been completed had it not been for the help and support of the following people, who I would now like to thank.

Firstly, my primary and secondary supervisors Dr. David Kennedy and Dr. Iain Dawe for all their help and guidance throughout this project. Thank you Dr. Kennedy for your guidance through all stages of the project and for your excellent feedback and support when problems were encountered. Thank you Dr. Dawe for your MSG beach expertise and feedback, the supply of reports and other resources, assistance with fieldwork, and further thanks to you and GWRC for supplying funding towards the completion of this research.

I would also like to thank the other academic staff from the VUW Physical Geography Department, particularly Professor Michael Crozier and Dr. Nick Preston for maintaining my interest in geomorphology, and my office crew Katie Jones, Helene Marsters and Erin Baylis for providing me with laughs and sharing the burden of being in the same situation.

The vast array of field equipment, software and other resources used in the completion of this project would have undoubtedly overwhelmed me if it were not for the technical guidance of Andrew Rae, Hamish McKoy and Josephine 'Gigi' Woods. Additionally, no fieldwork would have been conducted had it not been for the fearless dedication of my squadron of field assistants, so a big thank you to Louise Odlin, lain, Hamish McKoy, Nick Mulcahay, Helene Marsters and Liz Stichbury for their assistance in surveying Eastbourne's coastline.

I would like to thank my sister Rachel and her boyfriend David 'Kartron Malfunction' Katz for being so understanding and not kicking me out into the street despite my steady decline in housework contribution over the last 18 months. Many thanks to my parents Bob and Mandy for all their support over the last 27 years and for being awesome parents and role models to my siblings and me.

I would like to emphasize how grateful I am to my last minute support crew, who stepped in at the $11^{\text {th }}$ hour and all contributed to the completion of this project. This includes Alexa Van Eaton and James Muirhead, Louise Odlin and Rajarshi Dasgupta. Your collective generosity has overwhelmed me, and I hope that in time I am able to repay your kindness in one way or another.

And most importantly, a very special thank you Evelien van de Ven for your help and support in the final stages of this process. Thank you for your relentless proofreading and inspirational words of wisdom, and thanks for being a calming influence during those last frantic weeks. Your help over the last two months has been invaluable and I feel blessed to have had the privilege of meeting you. 


\section{Table of Contents}

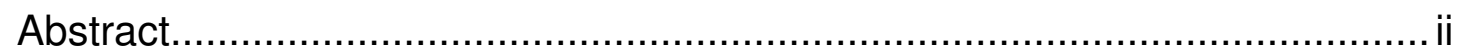

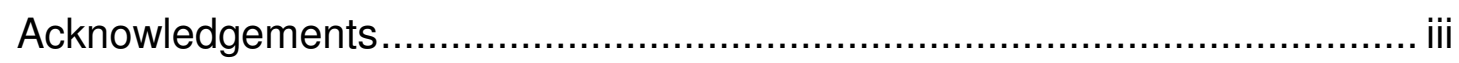

Table of Contents ….............................................................................. iv

List of Figures ............................................................................. vii

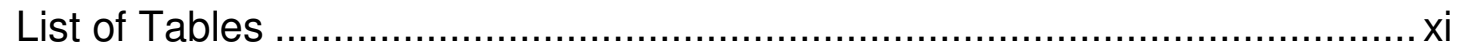

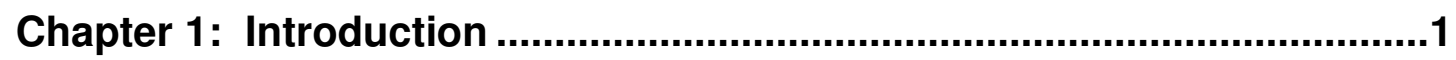

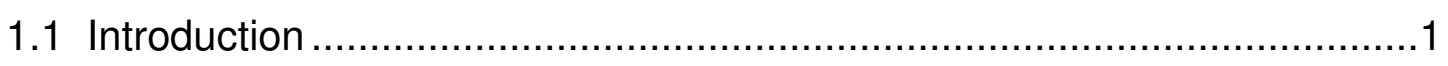

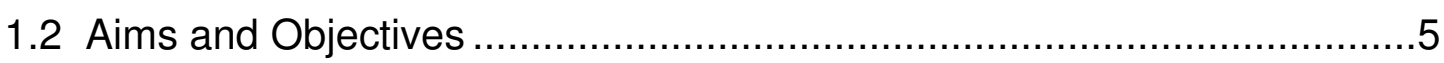

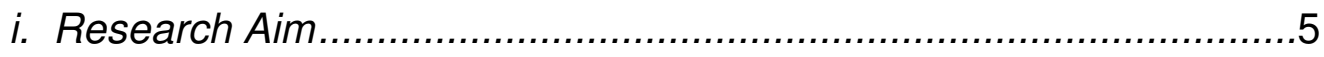

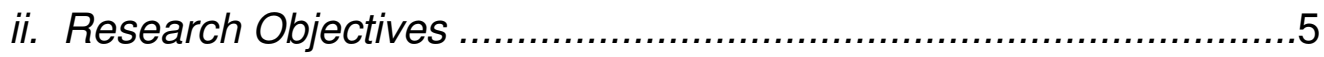

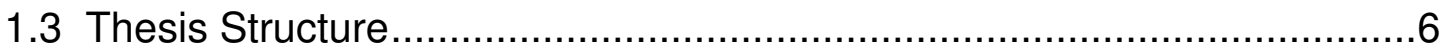

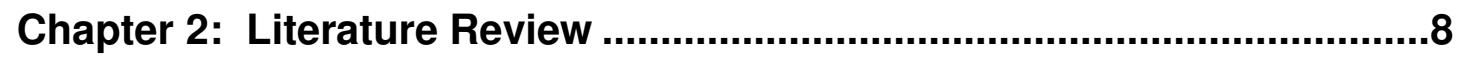

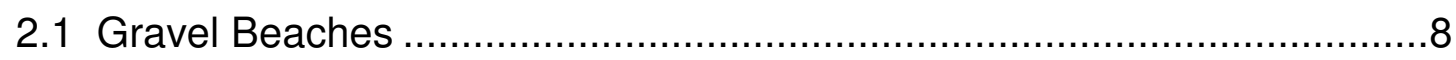

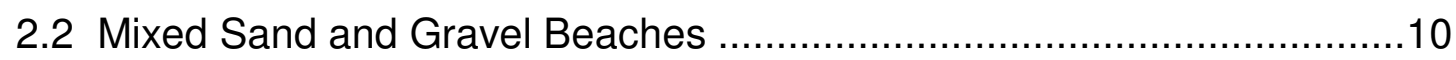

2.2.1 MSG Beach Morphology and Sedimentology..........................11

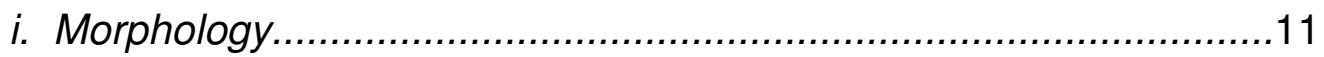

ii. Morphological Adjustment ...........................................................15

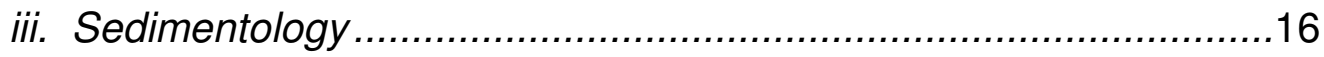

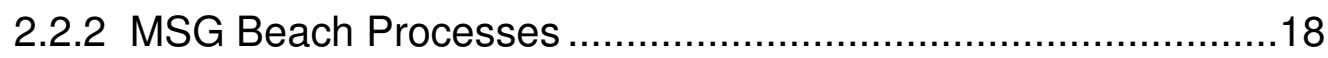

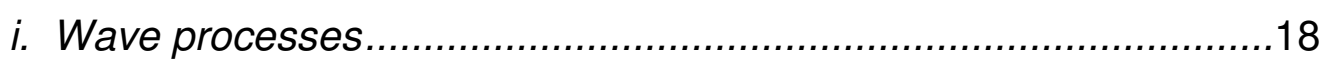

ii. Factors influencing transport processes ......................................19

2.3 Sediment transport in a fetch-limited setting ......................................20

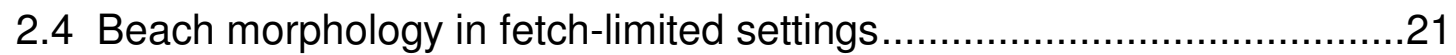

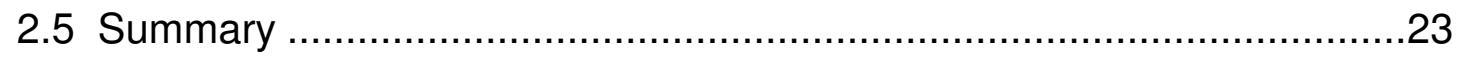

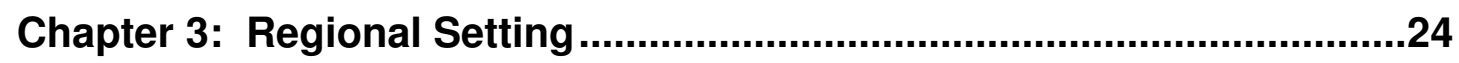

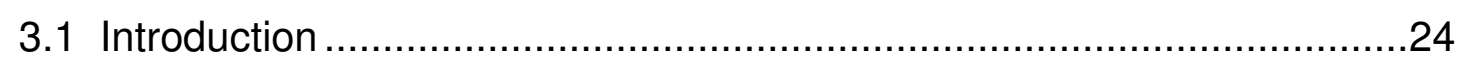

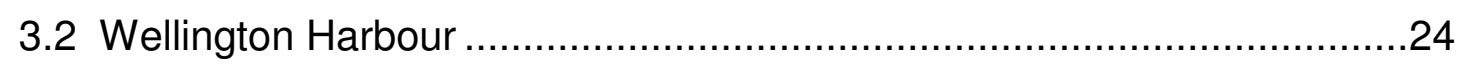

3.3 Geological setting of the Wellington Region .....................................28 


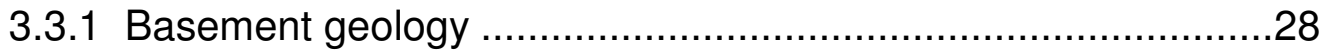

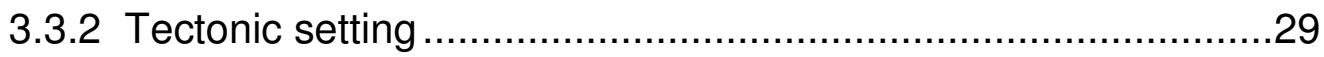

3.4 Geomorphology of Eastbourne and Pencarrow Coast............................30

i. Eastbourne and the Northern Bays ..............................................

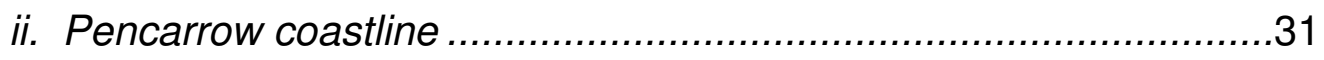

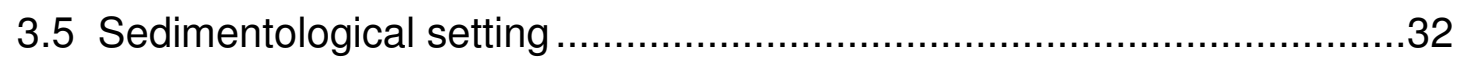

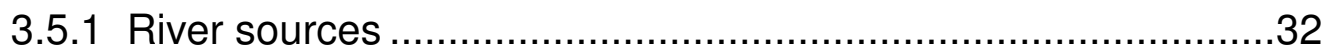

3.5.2 Re-deposition from offshore sources .....................................32

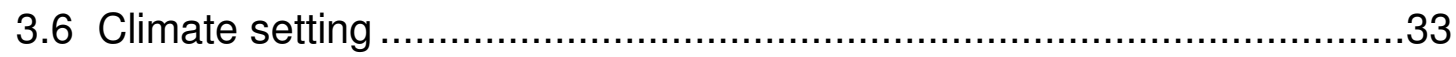

3.6.1 Climate overview.............................................................. 33

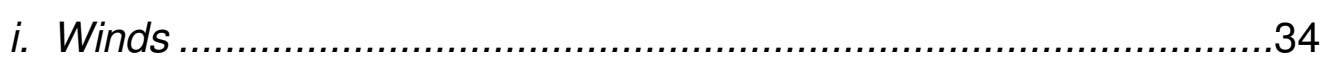

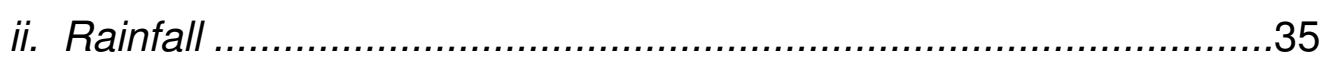

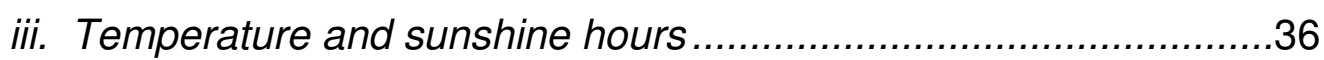

3.6.2. Low frequency high magnitude (LFHM) meteorological events

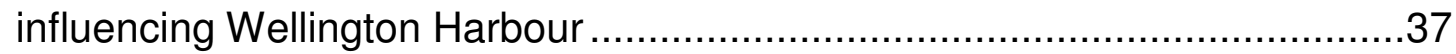

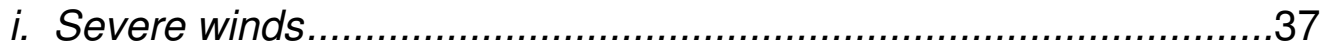

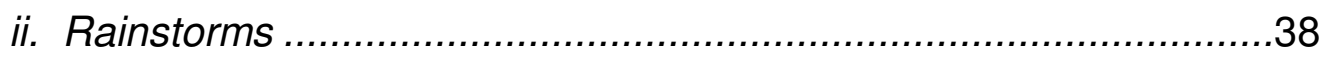

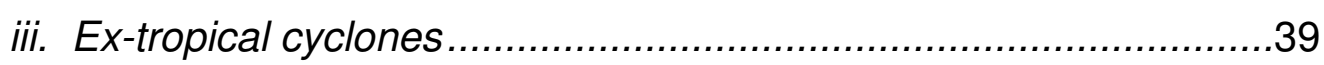

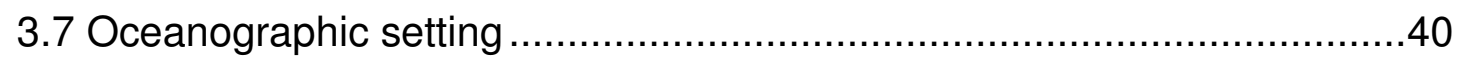

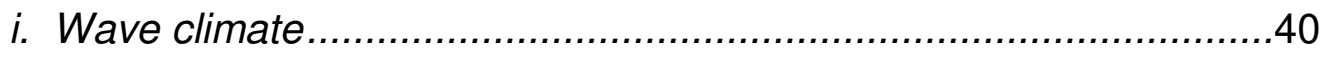

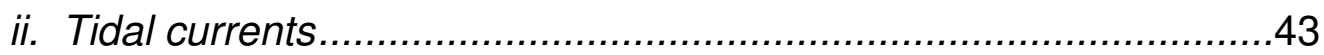

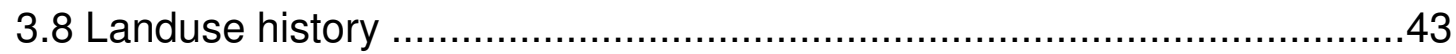

i. Settlement and development....................................................... 43

ii. Coastal modification and erosion mitigation .................................43

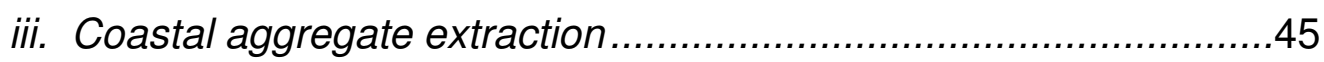

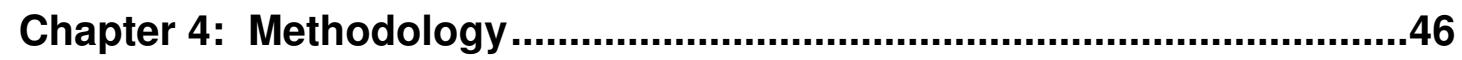

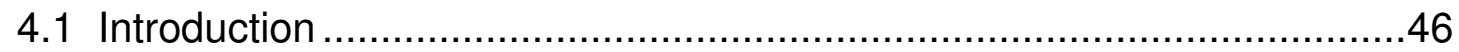

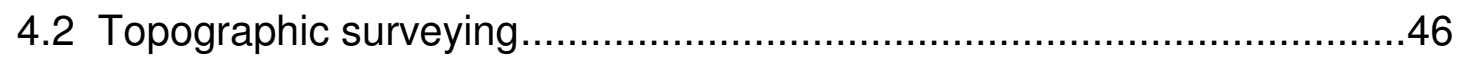

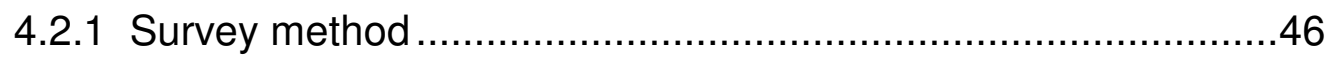

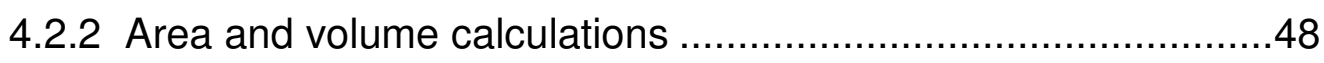

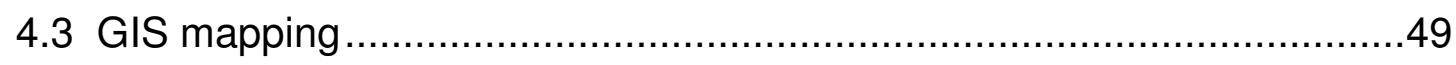

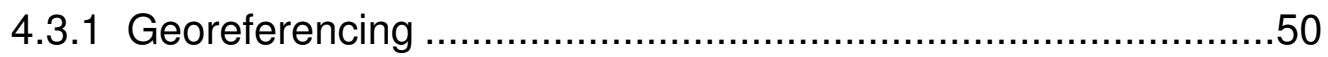


4.3.2 Digitising features and the calculation of historical shoreline

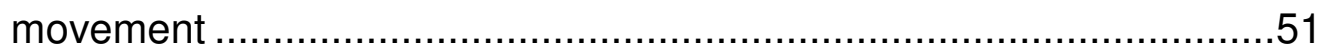

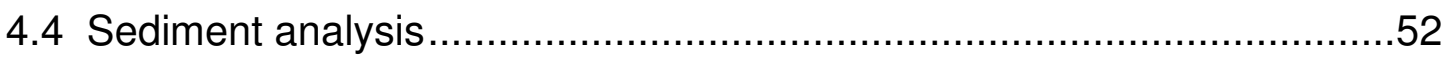

4.4.1 Surface sediment collection ..............................................53

4.4.2 Calliper measurements ...........................................55

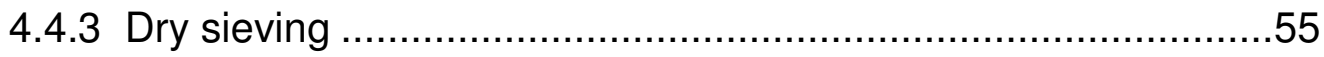

4.4.4 Laser diffraction analysis ................................................57

Chapter 5: Results .........................................................................61

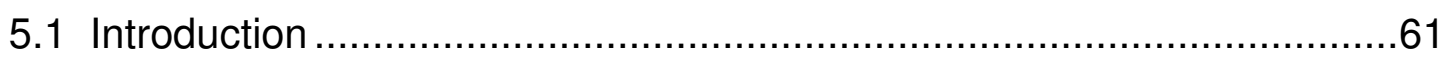

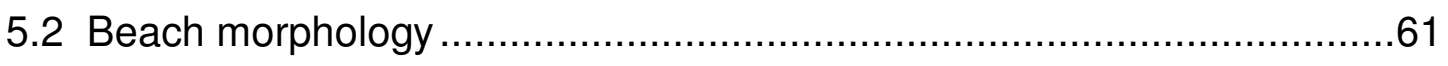

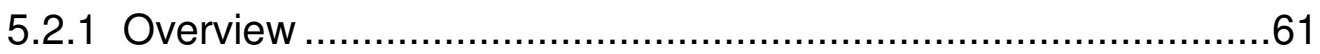

5.2 .2 Longshore variation in beach width ..................................62

5.2.3 Cross sectional morphology .............................................

i. Days Bay...................................................................... 71

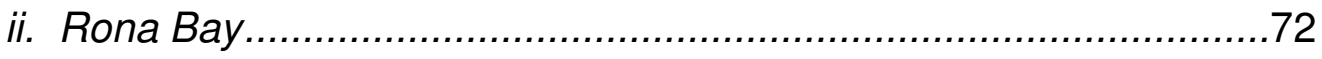

iii. Robinson Bay ................................................................ 73

iv. Burdens Gate - Pencarrow ............................................... 75

v. Cross sectional area and beach volumes.................................76

5.3 Temporal changes ......................................................................... 79

5.3.1 Short term and seasonal variation......................................79

5.3.2 Decadal scale shoreline position.........................................80

i. Historic beach width - Days Bay ........................................ 81

ii. Historic beach width - Rona Bay ...................................... 82

iii. Historic beach width - Robinson Bay .................................... 83

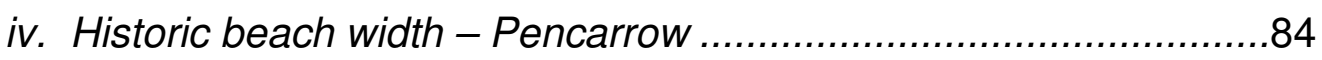

5.3.3 Historic beach erosion / accretion .......................................85

5.3.4 Gravel front northern migration rates ................................. 88

5.3.5 Temporal changes in beach area .....................................90

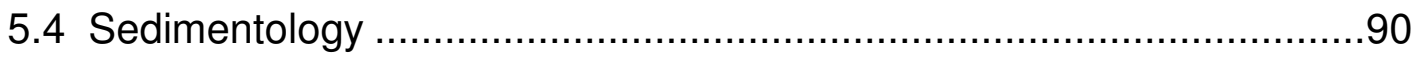

5.4.1. Grain size analysis ............................................... 90

i. Overview.............................................................. 90

ii. Mean grain size ........................................................ 92 
Chapter 6: Discussion

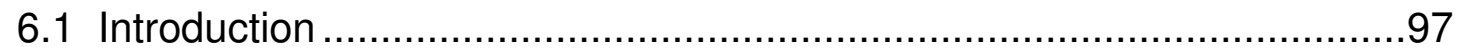

6.2 Observed morphological adjustment of the coastline ..........................98

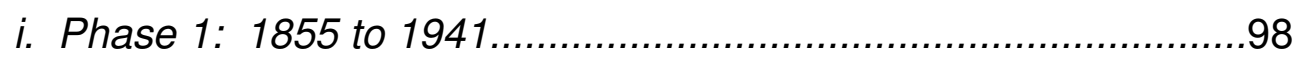

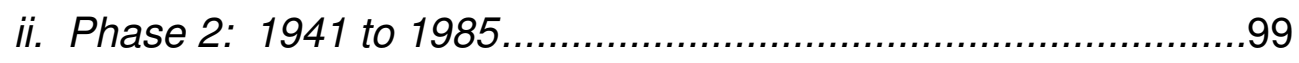

iii. Phase 3: 1985 to Present..................................................100

6.3 Evidence for permanent change on the Eastbourne coastline ..............101

6.4 Drivers of coastal change in Eastbourne ........................................103

6.4.1 Tectonic uplift and shoreline advance .................................103

6.4.2 Longshore sediment transport processes ..............................105

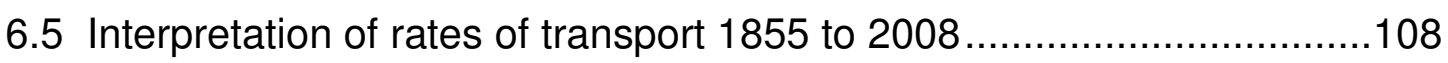

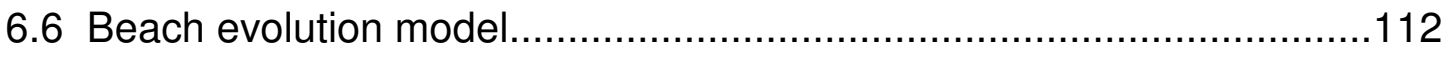

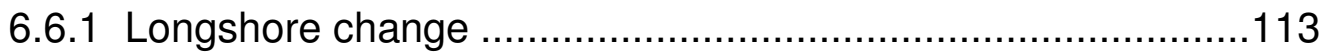

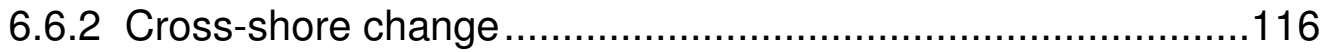

6.7 Significance of gravel on beach stability ………...........................118

6.8 Stability and sea level change ……………..............................119

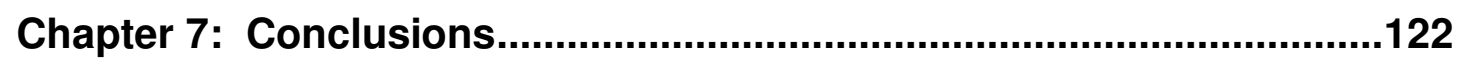

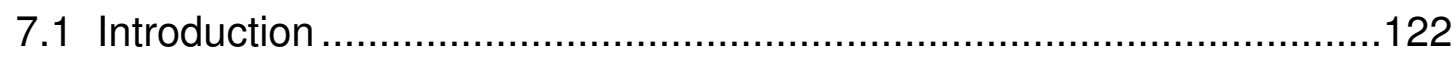

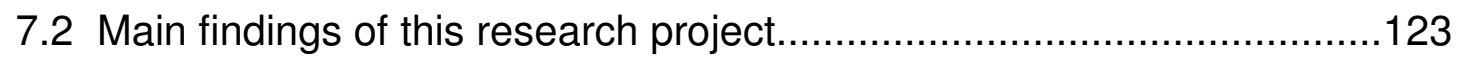

7.2.1 Permanence of the coastal changes at Eastbourne ................123

7.2.2 Shoreline evolution model ...............................................123

7.2.3 Northern migration rates of the gravel front............................124

7.2.4 Shoreline accretion quantities and rates of movement............124

7.2.5 Beach morphological variation ...........................................124

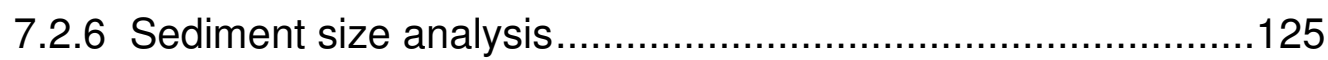

7.2.7 Drivers of change and future predictions...............................126

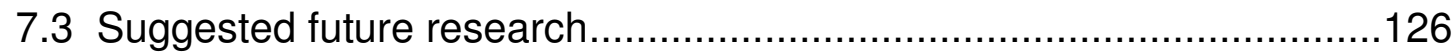

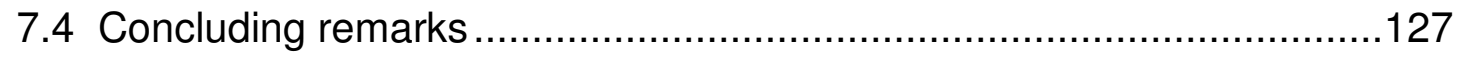

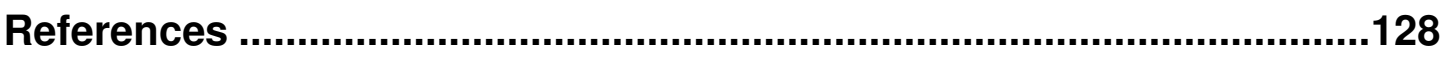

Appendices …….......................................................................136 


\section{List of Figures}

1.1 Photograph of erosion at the H.W. Shortt Recreation Ground of northern Robinson Bay, Eastbourne, following the stormy period of 1968 .

1.2 Photograph of northern Robinson Bay in 2009. 4

2.1 Coarse beach classifications in profile and plan views. 10

2.2 Mixed sand and gravel beach morphology in profile with principle elements

2.3 Cusp parameters showing the relationships between cusp elevation, depth, spacing and amplitude.

2.4 Low energy beach morphotypes 22

3.1 General location map of Wellington Harbour .................................25

3.2 Map of central Eastbourne and the Northern Bays..........................26

3.3 Location map of the Pencarrow Coast .........................................27

3.4 Sun-illuminated bathymetry grid of Wellington Harbour combined with $1 \mathrm{~m}$ contours

3.5 Wellington Airport Wind direction and wind speed from 1Jan-1960 to 25-Aug-2009.

3.6 Annual rainfall for Wellington Airport 1960-2008. ...........................36

3.7 Annual Rainfall for the Orongorongo Valley 1924-1974 ...................36

3.8 Relationship between wave energy and wind force for waves recorded at Beacon Hill on the opposite side of the Harbour entrance

3.9 Wave refraction diagram for the south coast

3.10 Construction of the boulder rip-rap in northern Robinson

Bay in response to erosion in the 1960s and 1970s.

3.11 Coastline at Lion's Rock looking north during the late 1950s following completion of the current sea wall

4.1 EDM surveying at Robinson Bay

4.2 Schematic diagram of technique used to calculate cross sectional area and volume of the section between profiles .50 
4.3 Aerial mapping procedure in ArcGIS .53

4.4 Map of sediment sample transects from Days Bay, Rona Bay and Robinson Bay.

4.5 Dry sieve stack and Fritsch mechanical shaker.

4.6 Photograph of LS13 320 Laser particle sizer. 59

4.7 Schematic diagram of the Beckman Coulter particle sizer 61

4.8 Photomicrographs of sediment $<1.41 \mathrm{~mm}$

5.1 Map of key features and survey sites for Days and Rona Bays .63

5.2 Subaerial beach width of Days Bay and Rona Bay ..... .64

5.3 Map of key features and survey sties for northern and southern Robinson Bay .66

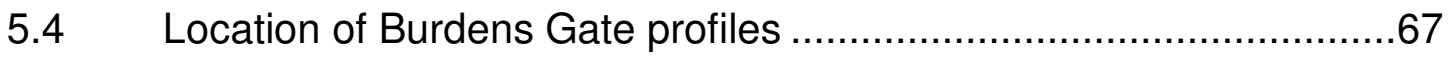

5.5 Subaerial beach width of Robinson Bay .......................................68

5.6 Map of survey sites for Pencarrow ……….................................70

5.7 Beach profiles southward from Days Bay and Rona Bay ................73

5.8 Photographs of lower foreshores in Robinson Bay..........................75

5.9 Characteristic Robinson Bay profiles from north to south........... 76-77

5.10 Beach profile 27 at southern end of Recreation .............................80

5.11 Beach profile 22, located 220m north of profile $27 \ldots \ldots \ldots \ldots \ldots \ldots \ldots \ldots . . .81$

5.12 Days Bay beach widths calculated from aerial photos.....................82

5.13 Beach width evolution of Rona Bay since 1941 .............................83

5.14 Beach width evolution of Robinson Bay since $1941 \ldots \ldots \ldots \ldots \ldots \ldots \ldots \ldots . . .84$

5.15 Cumulative beach erosion and accretion for the

Eastbourne and Pencarrow shoreline 1941-2008 .86

5.16 Average annual rates of shoreline movement for Eastbourne (Days Bay to Burdens Gate) 
5.17 Location of gravel front's northern extent through time

5.18 Photographs of Rona Bay emphasizing sediment size and morphology

5.19 Photos of Robinson Bay emphasizing dominance of gravel

5.20 Graph of longshore variation in grain size for all transects.... .93

5.21 Mean grain size versus sorting scatter graph for all samples Days Bay to Point Arthur .95

5.22 Percentage sand, granules and pebbles for Eastbourne sediment samples

6.1 Photograph depicting Robinson Bay in 1902.

6.2 Photograph of Boyd-Wilson's Garage at the south end of Puketea Street after extensive erosion.

6.3 Robinson Bay in 1984, showing the sea-wall and groyne system. 100

6.4 Aerial photos of Pencarrow Bay in 1941, 1975 and 2008 103

6.5 Wave refraction diagram for East Wellington Harbour. 106

6.6 Sun-illuminated Backscatter image of the Eastbourne Platform and Wellington Harbour 108

6.7 Wave refraction diagram for Turakirae Head to Eastbourne 111

6.8 Schematic diagram representing spatial variations in wavepower, roughness and drift rate for the EastbournePencarrow littoral cell

6.9 Schematic diagram of planform beach evolution through Eastbourne and Pencarrow....

6.10 Cross shore beach evolution model

6.11 Photograph of the southern prograding section at Robinson Bay section in 1960 .

6.12 Sea-level rise in New Zealand's main centres since 1900. 120 


\section{List of Tables}

3.1 Kelburn station rainfall prediction based on hindcast data between 1863-1985.

3.2 Maximum wave heights and significant wave periods for eastern Wellington Harbour

5.1 Beach widths of selected profiles as calculated from field surveying and GIS analysis

5.2 Pencarrow Beach widths and beach orientation from 2008 aerial photographs.

5.3 Width, change in elevation, subaerial width, cross sectional area and slope for Rona and Robinson Bays

5.4 Cross sectional area of subaerial beach profiles and volumes of sections between profiles for Rona Bay

5.5 Cross sectional area of subaerial beach profiles and volumes of sections between profiles for Robinson Bay 79

5.6 Data from Pencarrow Section aerial photo analysis .85

5.7 Net alongshore movement of gravel front from Orongorongo River 1941-2008..... .90

5.8 Shoreline areas calculated in GIS for Days Bay, Eastbourne and Pencarrow .90 


\section{Chapter 1: Introduction}

\subsection{Introduction}

Coastal erosion is a critical issue facing hazard and resource managers, due in part to increasing development within the coastal zone. As development of property and infrastructure intensifies on the coast, more elements are being put at risk as they become increasingly affected by natural cycles of erosion and accretion. This issue is now compounded by human-induced sea-level rise (IPCC, 2007). Global projected sea-level rise for the next 100 years is estimated to be between 0.18 and $0.59 \mathrm{~m}$, and there is a possibility that it could be as high as $0.8 \mathrm{~m}$ relative to the 1980-1999 average for parts of New Zealand due other factors omitted from global climate models. This includes the possibility of more rapid melting of the Greenland Ice Cap (Tait et al., 2008). Sea-level rise is projected to have significant impact on much of the world's coastline through inundation of low lying coastal areas, increasing coastal erosion rates in many areas, and through providing a relatively higher base level for other hazard events (Pethick, 2001 IPCC, 2007). Additionally, the intensity of extreme weather events is likely to increase as sea surface temperature and latent energy in the atmosphere rises (IPCC, 2007; MfE, 2007; Tait et al., 2008).

This is especially an issue in New Zealand as nearly all of its major urban centers are situated near estuaries or harbours, and there is currently less known about their shoreline dynamics compared to open coast beaches. Additionally, the response of estuarine shorelines to sea-level change is complex (Pethick, 2001). In New Zealand, measurements from tide gauges from the main centers show sea levels have been rising consistently at rates between $0.9-2.1 \mathrm{~mm} / \mathrm{yr}$ for the past century (Hannah, 1990, 2004). Climate-change induced sea-level rise will most likely cause increasing erosion rates in estuarine and harbour beaches that are already erosional, and initiate erosion on stable or accreting beaches (Nordstrom, 1992). This is because as sea levels rise, waves are able to 
encroach further inland, allowing sediment to be removed from above the present swash runup limit.

This research project aims to investigate a sheltered harbour shoreline that shares many of the characteristics of an estuarine system, which is located along the eastern coast of Wellington Harbour. The study site focuses on the suburban shoreline of Eastbourne, particularly the northern end of Robinson Bay. This area is a fetch-limited environment and a gravely coast. The morphodynamics of gravel beaches on the open coast is only recently being clarified (Kirk, 1980; Mason and Coates 2001), those in estuaries/harbours are comparatively poorly understood (Nordstrom, 1992; Postma and Nemec, 1990; Dawe, 2006). Osborne and Chen (2005) note there are relatively few quality field measurements of coarse-grained sediment transport regimes operating on mixed-grain beaches, and existing models for coarse and mixed-grain sediment transport are limited at present. Certainly what is known is that gravel beaches respond differently to sea-level change than sandy beaches, and further understanding of gravel beach dynamics is needed to fully understand possible effects on gravel beaches and to instigate plans to mitigate them (Austin and Masselink, 2006; Buscombe and Masselink, 2006).

Wellington Harbour faces significant coastal hazard issues and there is a need to understand the contemporary behaviour of its beach systems (Tait et al., 2002) and past dynamics to place current coastal changes within a wider temporal and spatial context and allowing prediction of future coastal adjustments. The study area in Eastbourne has experienced erosion problems from the early 1900s, leading to the construction of a seawall and extensive groyne fields during the 1950s. These protective measures shifted the erosion north of the seawall, which experienced substantial shoreline retreat in the 1970's (Fig. 1.1) (Matthews, 1980a). 


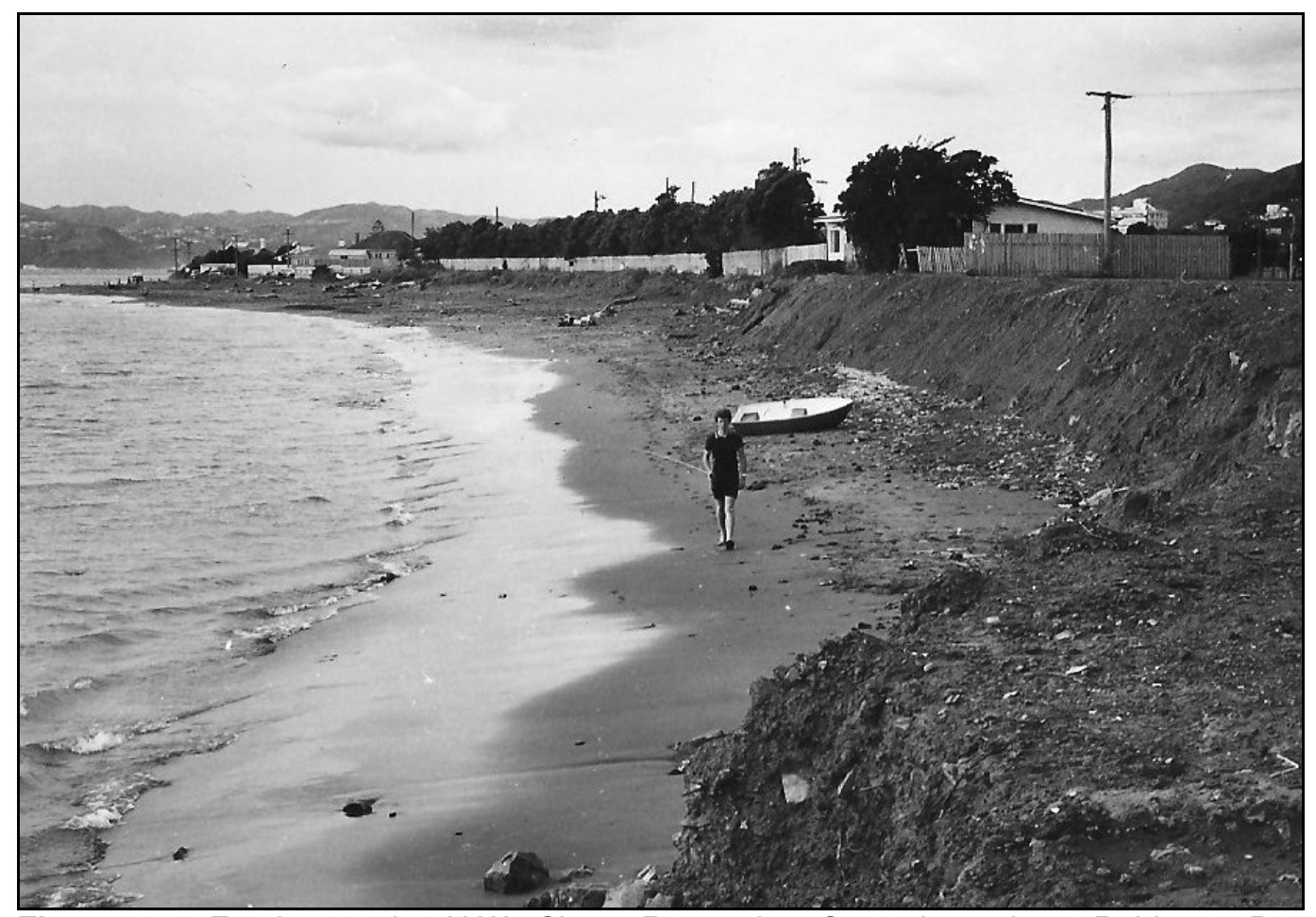

Figure 1.1: Erosion at the H.W. Shortt Recreation Ground, northern Robinson Bay, Eastbourne following the stormy period of 1968 that included the Cyclone Gisele on April 10 (Cunningham, 1969, courtesy of the Eastbourne Historical Society).

At present this system has switched to a period of accretion and coastal progradation, as a large mobile gravel front migrates north from the Orongorongo River into the harbour entrance (Matthews, 1980a, 1980b; Carter, 1977). The impact of this coarser sediment in the system has changed the sedimentology and the morphology of this beach system. The beach north of the sea wall at Eastbourne has built out substantially due to longshore deposition of coarse sediment as the gravel front has reached central Eastbourne from 1985 onwards (Fig. 1.2) (Gibb, 2005). This research is primarily focused on understanding the behaviour of this gravel front along the Eastbourne coast. Cotton (1974) in his early extensive qualitative studies of the Wellington coast has suggested that on a geological timescale, progradation of the Wellington coast is a temporary interruption in the wider cycle of marine erosion in the area. However, Gibb (2005) states that this section of coastline has been advancing through periodic uplift and consequential deposition of throughout the Holocene, and that Robinson Bay and Rona Bay in central Eastbourne have both undergone periods of shoreline advance and retreat between 1863 and present day. 


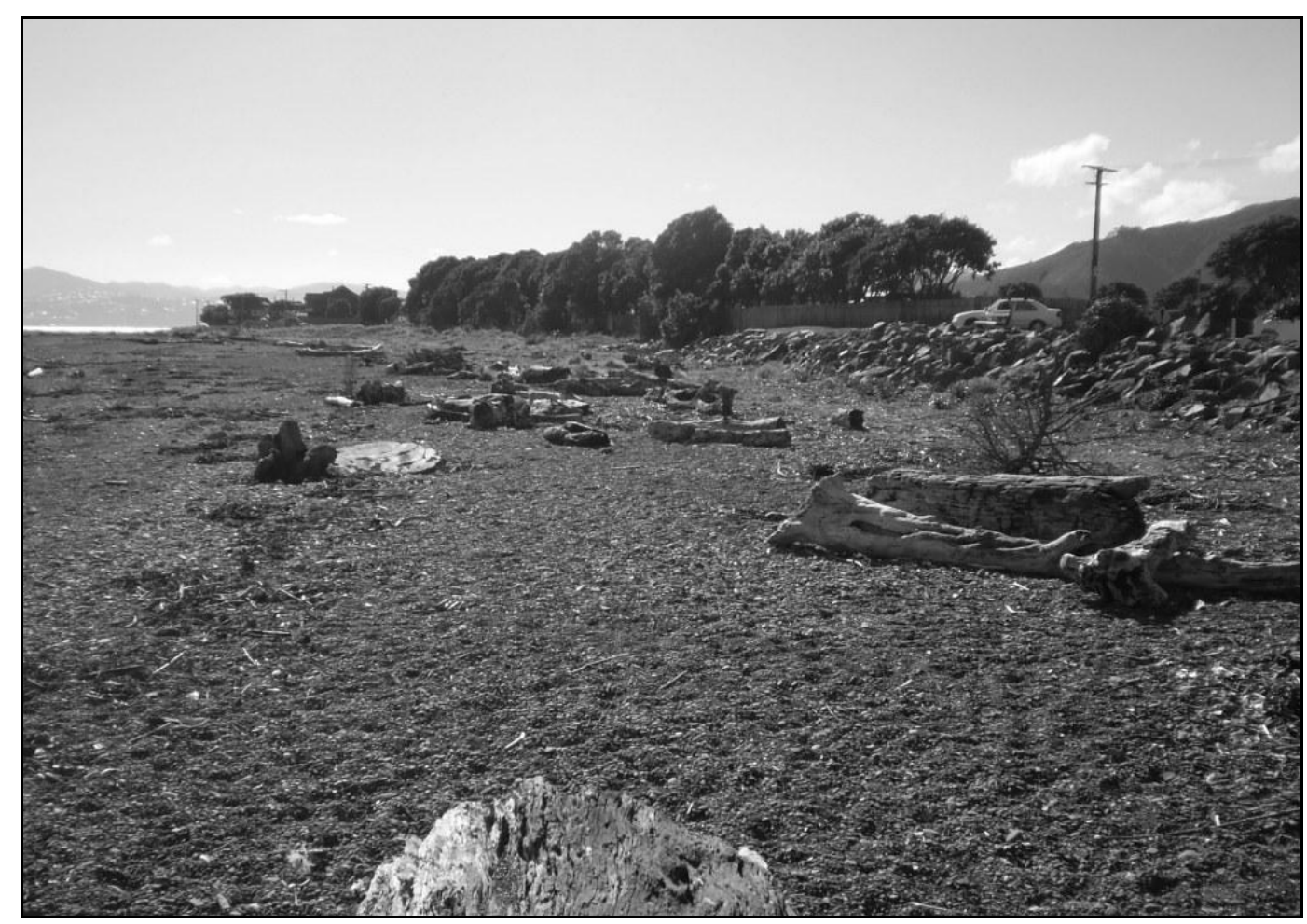

Figure 1.2: Northern Robinson Bay looking north towards the H.W. Shortt Recreation Ground and Point Webb in 2009. This shows the recent progradation caused by the northward-moving mobile gravel front.

Carter (1977) and Matthews (1980a,1980b) have examined the gravel and sand transport patterns along this area of the coast, and have concluded that the mobile gravel front is migrating northward at a rate of $0.42 \mathrm{~km} / \mathrm{y}$ but their results lack quantification of volumes and rates over a longer temporal scale, and were last updated in 1980. An updated analysis of the extent and impact of the gravel front as it changes the morphology of the beaches of central Eastbourne will provide insight into mixed beach morphological adjustment within a fetch limited environment. 


\subsection{Aims and Objectives}

\section{i. Research Aim}

Past research has clearly shown that the Eastbourne coastline is undergoing significant morphological change in a relatively short timescale. The question therefore arises: Does this change relate to a shift in the systems sediment supply, or just a temporary cycle? To investigate these problems the following research objectives have been developed.

\section{ii. Research Objectives}

This project aims to investigate the historical shoreline change in Eastbourne by:

\section{- Quantifying rates of erosion and accretion}

This research aims to provide a comprehensive assessment of the rates of erosion and accretion along the Eastbourne shoreline, particularly at the northern end of Robinson Bay. This will be achieved using spatial and temporal topographic surveying of selected beach profiles combined with historic aerial photograph analysis of shoreline position through time. This will be combined with as sediment size analysis to describe the composition of the shoreline and how grain size varies spatially in relation to the influx of the new sediment supply into the littoral drift system.

\section{- Identifying thresholds driving these cycles}

Gravel beaches have been shown to respond differently to marine processes than sandy beaches (Woodroffe, 2002), and as such do not fit many of the traditional models of beach response to changes in sediment supply and sea-level change (Buscombe and Masselink, 2006). This project will attempt to shed light on the 
sensitivity of these systems to boundary level changes and help to provide more data on gravel beach systems.

\section{- Assessing the sensitivity of the system and its likelihood to return to an erosional phase}

At present, Robinson Bay and Rona Bay are prograding, but in previous decades they have experienced significant (decadal) phases of erosion. This research will attempt to understand how this section of the coast will respond in the future and to assess whether the current progradation is a shorter or longer term change. It will also discuss possible scenarios of the systems response to predicted sea-level rise and associated changes in dynamics.

\section{- Helping establish a morphological monitoring program for Eastbourne}

The field and laboratory analysis conducted for this research project will provide a context for future monitoring of temporal changes in beach profile and sedimentation. The results from this study will allow informed decisions to be made regarding the location of survey sites to monitor future shoreline change.

\subsection{Thesis Structure}

This report is divided into seven chapters. Chapter Two is a review of the relevant research on gravel and mixed beaches, sediment transport mechanisms and estuarine beach morphology and dynamics. Chapter Three is a description of the regional setting including the important physical characteristics and environment processes operating in the area. Chapter Four outlines the methodology of the fieldwork conducted, and Chapter Five presents the results gathered from beach surveying and sediment analysis conducted in the field, including the historic photograph analysis of shoreline positions. Chapter Six discusses the findings from in 
relation to shoreline stability, and finally Chapter Seven provides relevant conclusions and suggestions for future research. 


\section{Chapter Two: Literature Review}

\subsection{Gravel Beaches}

Globally, gravel beaches are relatively uncommon and as such they are a relatively unstudied phenomena, with most littoral literature focusing on more common sandy beaches (e.g. Short, 1979; Shih and Komar, 1994; Lippman and Holman, 1990). Additionally, gravel beach coastal zones are often high energy environments, and direct measurements of beach dynamics are hindered by the impact of high energy waves on surveying equipment. While they are globally less common than sandy beaches, there are areas with extensive coarse beaches, particularly in the United Kingdom, Canada, Japan, Russia and New Zealand (Buscombe and Masselink, 2006).

However, coarser grained beaches are attracting interest in coastal science. This is largely from an engineering perspective as land managers attempt to understand coarse beach responses to artificial beach renourishment and other anthropogenic coastal alterations (Mason and Coates, 2001). Much of the gravel beach literature has focussed on the morphology and sedimentology of gravel beaches (e.g. Bluck, 1967; Carter et el., 1990; McLean and Kirk, 1969; Caldwell and Williams, 1985; Kirk, 1980; Jennings and Shulmeister, 2002). Others have studied the longer-term evolution of gravel beach systems (e.g. Orford and Carter, 1995; Orford et al., 1991). In recent years there have also been studies into gravel beach short-term processes (e.g. Buscombe and Masselink, 2006, Mason and Coates, 2001; Ivamy and Kench, 2006).

Although all beaches are littoral environments, gravel systems have been shown to behave differently to sandy beaches in a number of respects. This can be largely attributed to the differences in sediment properties between these two systems. Sandy beaches primarily respond to changing marine energy conditions both sub-aerially and sub-tidally, while gravel beaches are essentially sub-aerial landforms (Kirk, 1980). Gravel 
beaches are often classified based on their morphology and sedimentology. Coarser beach systems may vary along a continuum composed of grain sizes between 2 and $256 \mathrm{~mm}$ (Austin and Masselink, 2006), and can be divided into three categories; pure gravel, composite and mixed sand and gravel (MSG) beaches (Jennings and Shulmeister, 2002). Pure gravel beaches (Fig. 2.1. A) are identifiable by the virtual absence of fines, with a fairly uniform and well sorted grain size distribution. These gravels generally have a mean grain size range from -2 to $-6 \varphi$ (Jennings and Shulmeister, 2002). They have relatively steep beach faces and comparatively narrow widths of between 18 and $50 \mathrm{~m}$ (Jennings and Shulmeister, 2002). They remain highly reflective throughout the entire tidal cycle and their morphology is cusp dominated through the influence of edge wave processes (Fig. 2.1) (Sherman et al., 1993). Composite beaches are classified as those which have a distinct sandy low tide terrace, splitting their profiles into two distinct parts due to hydraulic sorting (Jennings and Shulmeister, 2002). These systems operate under two different wave process regimes, with spilling waves developing on the dissipative surf zone at low tide, and reflective waves operating on the gravel landward section during high tide. Beach widths may vary from less than $20 \mathrm{~m}$ to over $60 \mathrm{~m}$, not including the low-tide surf zone (Fig 2.1. C).

The third type includes mixed sand and gravel (MSG) beaches (Fig. 2.1. $B)$, characterized by a homogenous combination of sand and gravel mixed both horizontally and vertically (Kirk, 1980). Eastbourne's beaches have been identified as being mixed (Matthews, 1982). This literature review will now therefore focus on mixed sand and gravel beaches. 

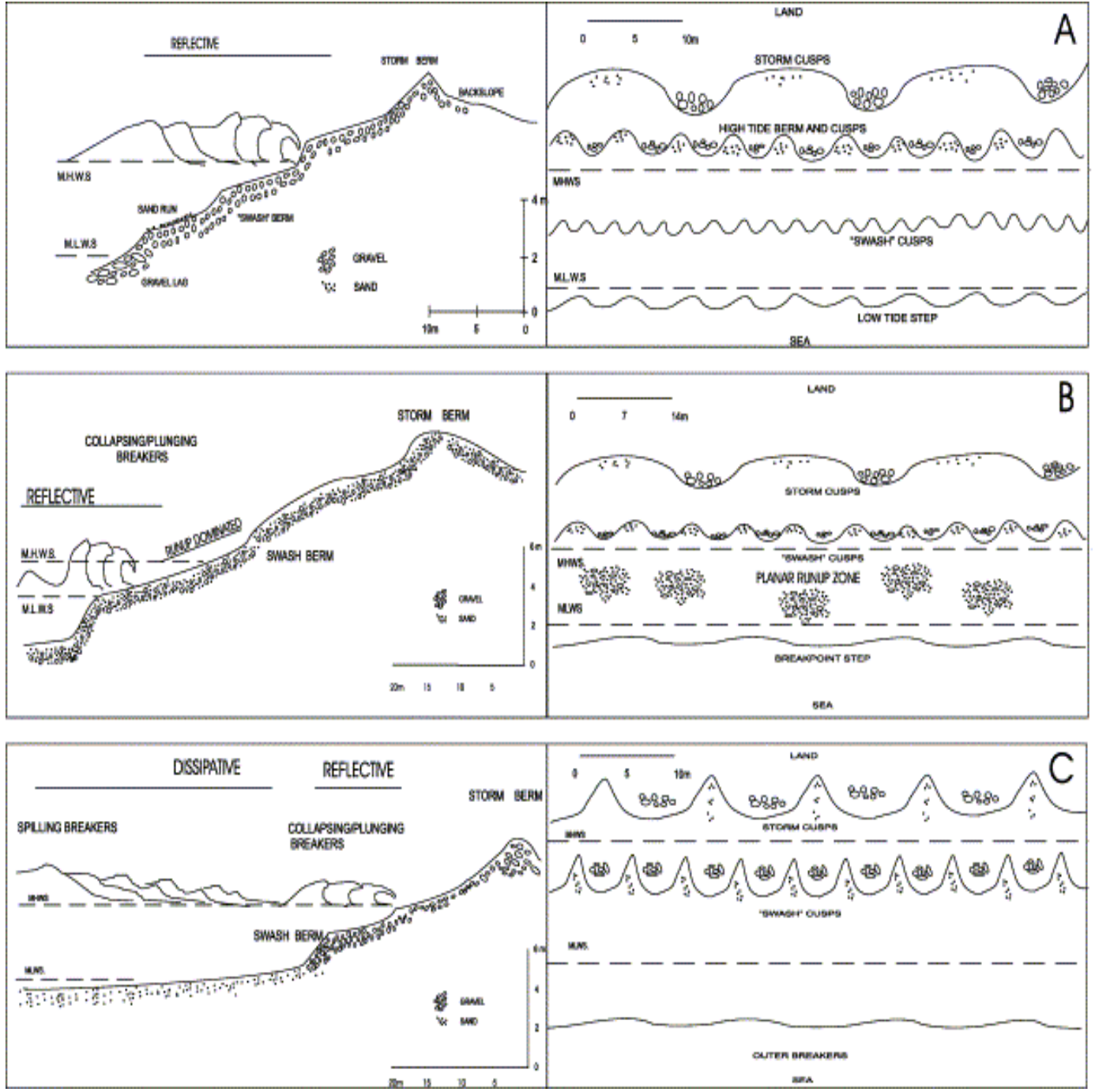

Figure 2.1: Coarse beach classifications in profile and plan views. Pure gravel (a), MSG (b), and composite (c) (Jennings \& Shulmeister, 2002, p. 224).

\subsection{Mixed Sand and Gravel Beaches}

Mixed sand and gravel beaches share many of the features common to gravel systems in general, but are considered more complex than either sand or pure gravel beach systems (Zenkovich, 1967). They have been identified as distinctly different landforms from other coarse beaches as early as 1929 (Marshall, 1929), but most of the mixed beach literature is from the late 1960's onwards. A significant amount of this research has been conducted in New Zealand, with a focus on the morphology and sedimentology of these systems (e.g. McLean, 1970; McLean and Kirk, 1969; Kirk, 1980; Dawe, 1997, 2001, 2006; Jennings and Shulmeister, 2002), and to a lesser extent there has been research into MSG 
nearshore processes swash zone dynamics (Kirk, 1975; Mason and Coates, 2001; Ivamy and Kench, 2006).

MSG beaches are common in areas that have a surplus of gravels supplied under glacial conditions, which are then reworked by marine processes under Holocene sea levels (Mason and Coates, 2001). This includes places such as the United Kingdom (Kulkarni et al., 2004; Horn and Walton, 2007) and Canada (Engels and Roberts, 2005). In New Zealand, particular attention has been paid to those in the east coast of the South Island (Kirk, 1980). They also occur extensively along parts of the west coast of both Islands (Dawe, 1997), where gravel eroded from hinterland fans is the primary sediment source (Kirk, 1980).

McLean (1970) has described MSG beaches as having approximately equal proportions of sand and gravel. However, it has not been definitively asserted what proportion of sand or gravel is needed for a beach to be classified as mixed, with reported sand content varying from 15 to $68 \%$ (Mason and Coates, 2001). What is distinct about the mixing of varying sediment sizes in these systems is that it occurs both horizontally across and alongshore, as well as vertically through the beach profile. This combination of coarse and fine sediment mixing creates unique grain size distributions and a morphology exclusive to MSG beaches.

\subsubsection{MSG Beach Morphology and Sedimentology}

\section{i. Morphology}

MSG beaches are generally 100-200 m wide (Kirk, 1980), but may be narrower than 20m if eroding (Dawe, 1997). They are relatively steep with average slopes between $5-12^{\circ}$ (Kirk, 1980). This is largely attributable to the higher angle of repose of gravel creating steeper slope angles than sandy systems (Austin and Masselink, 2006) These beaches are typically convex in shape with average elevations of 4-6 $\mathrm{m}$ above mean sea level. Kirk (1980) has identified four principal elements that compose a MSG 
beach. These are the backshore, foreshore, breakpoint and nearshore zones (Fig. 2.2).

The backshore zone refers to the most landward area of the beach, identified as the area behind the highest runup limit of storm swash (Kirk, 1980). It is situated behind the storm berm and is often marked by the presence of the coarsest sediments of the system. These sediments are also often relatively discoid in shape. Their shape and size reflects the differential power between storm uprush and backwash, as their deposition can be attributed to the loss of energy and inability to re-entrain particles of a backswash wave motion (Buscombe and Masselink, 2006).

The second zone identified by Kirk (1980) is the foreshore zone (Fig. 2.2), which can be further divided into the upper and lower foreshore. The upper foreshore is situated behind the high tide berm and generally contains at least one storm berm. The upper foreshore often reflects longer term morphological change, dependent on relative sea-level, sediment supply regimes and local climatic conditions (Orford et al., 1996). Berms are formed immediately landward of the swash runup limit, so their presence is indicative of changes in a beaches hydraulic regime, either through the tidal cycle, or through changes in wave energy. This can provide a brief historical account of storm or high energy wave events, of usually one to two years, but may be longer on a prograding beach system (Dawe, 1997). Berm quantity and height in the upper foreshore is related to sediment supply with high supply rates contributing to multiple berm ridge morphology. Lower supply rates results in a single asymmetrical berm (Mason and Coates, 2001).

The lower foreshore extends from the high tide berm across the swash zone to the breakpoint step. It is the area that is subject to the most morphological change as it is the location of the swash zone, and swash zone sediment transport is dominant in MSG beaches (Jennings and Shulmeister, 2002). This zone is typically wider than on a pure gravel beach due to the finer sediment in an MSG swash zone (Shulmeister and 
Rouse, 2003). The breakpoint step is a feature common to most gravel beaches, and to many reflective sand beaches. This is a comparatively small, steep break in slope at the base of the active beach face that separates it from the nearshore zone (Buscombe and Masselink, 2006). The step adjusts to the nearshore hydrodynamic regime, and is the feature that forces waves to break, transforming wave energy into swash. The position of the breakpoint step in a MSG beach remains constant throughout the tidal cycle, so wave breaking is restricted to a narrow section of the profile under average wave conditions.

The nearshore zone is immediately seaward of the breakpoint step (Fig. 2.2) and consists of a steep nearshore face $\left(>20^{\circ}\right)$ composed of coarse pebbles and cobbles that extends continuously alongshore (Kirk, 1980). The base of this slope intersects the gently sloping inner shelf comprised of fine silts and sands unable to remain on the active beach face (Dawe, 1997). This is a feature distinctive to MSG beaches, and clearly marks the boundary between the seaward limit of the active beach, and the sandy inner shelf (Kirk, 1980).

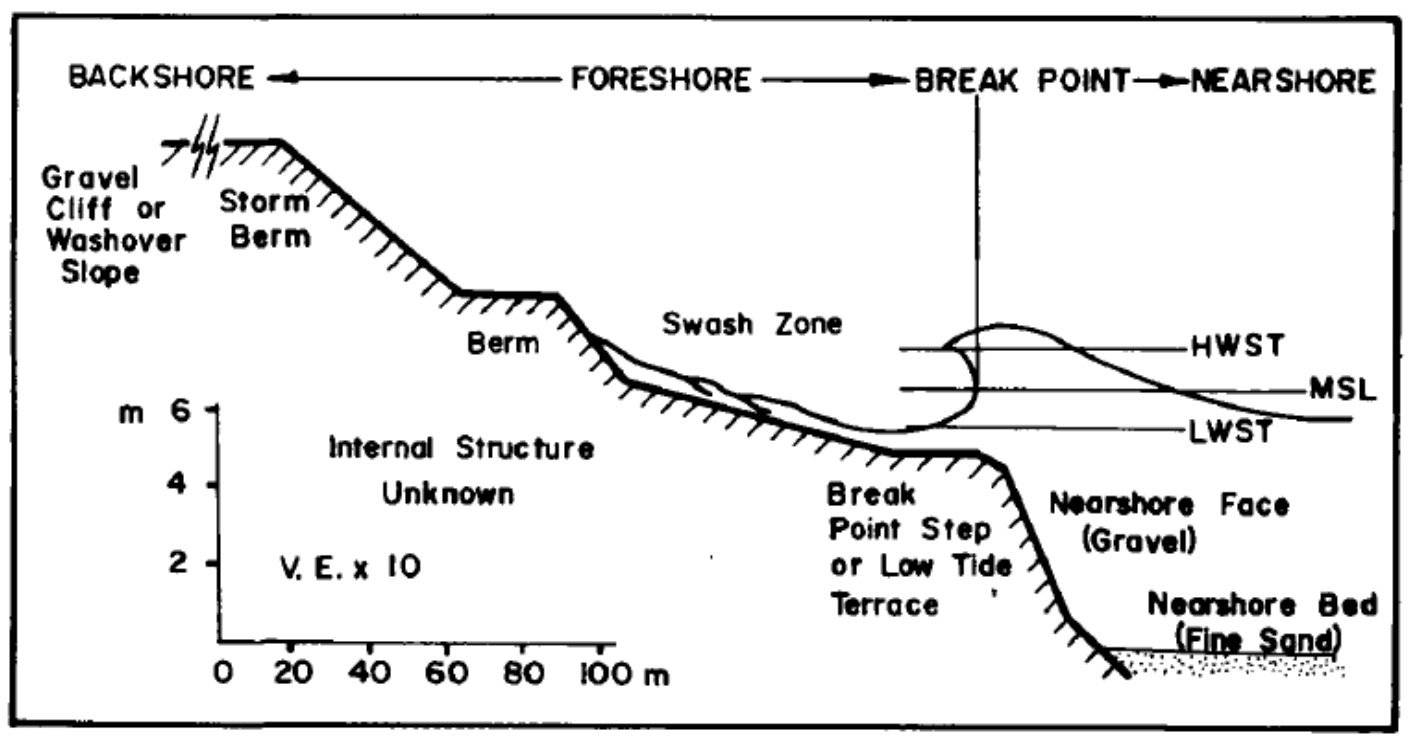

Figure 2.2: MSG beach morphology in profile with principal elements (Kirk, 1980).

Steep slope angles and the absence of a distinctive surf zone have meant that the MSG beach has often been classified as a reflective morphotype, similarly to a pure gravel beach. It is noteworthy, however, that many MSG 
beaches share aspects of the composite gravel beach morphology, with a primarily sandy low tide terrace clearly separated from a gravel upper foreshore and backshore zones (Wright and Short, 1984). Typically the low tide terrace has a low gradient compared to the rest of the foreshore, meaning during low tide and under reduced wave energy, MSG beaches may adopt a dissipative beach morphodynamic regime, with reflective conditions being reinitiated at mid to high tide. Horn and Walton (2007) have stated that these mixed-composite beaches are a common feature in the UK, and they differ from standard composite beaches in that the upper beach face is mixed sand and gravel, rather than pure gravel.

The foreshore zones of MSG beaches often develop cusps at the landward limit of swash runup (Kirk, 1980). Beach cusps are rhythmic crescent-shaped features related to swash action (Woodroffe, 2002). They are often associated with low wave energy environments and reflective beach morphotypes (Masselink et al. 1997). They consist of a series of small cusp embayments separated at even spacings by mounds known as cusp horns (Nolan et al., 1999). Nolan et al. (1999) have investigated cusp morphology in MSG beaches on both coasts of New Zealand's South Island. Variables measured in this research were cusp elevation, spacing, amplitude and depth (Fig. 2.3). Of the 68 cusp sets measured, mean cusp spacings were found to be $2.95-87.43 \mathrm{~m}$, cusp elevation ranged from $6.66 \mathrm{~m}$ above MSL to $-0.71 \mathrm{~m}$ below MSL, amplitude from $0.05-2.70 \mathrm{~m}$, and cusp depths ranged from $2.50-41.20 \mathrm{~m}$ (Nolan et al., 1999). Up to three sets of cusps were identified, with spatial dimensions and age increasing with elevation up the beach profile (Kirk, 1980). Their findings are significant to MSG beach morphology as these beaches present a distinctive longshore formation to incoming waves, and cusps have been described as being a significant part of this longshore variation. This is brought about by a significant change in the lower foreshore morphology and sedimentation over a short distance $(<100 \mathrm{~m}$ alongshore), which in turn affects swash runup heights and inundation levels (Nolan et al., 1999). 


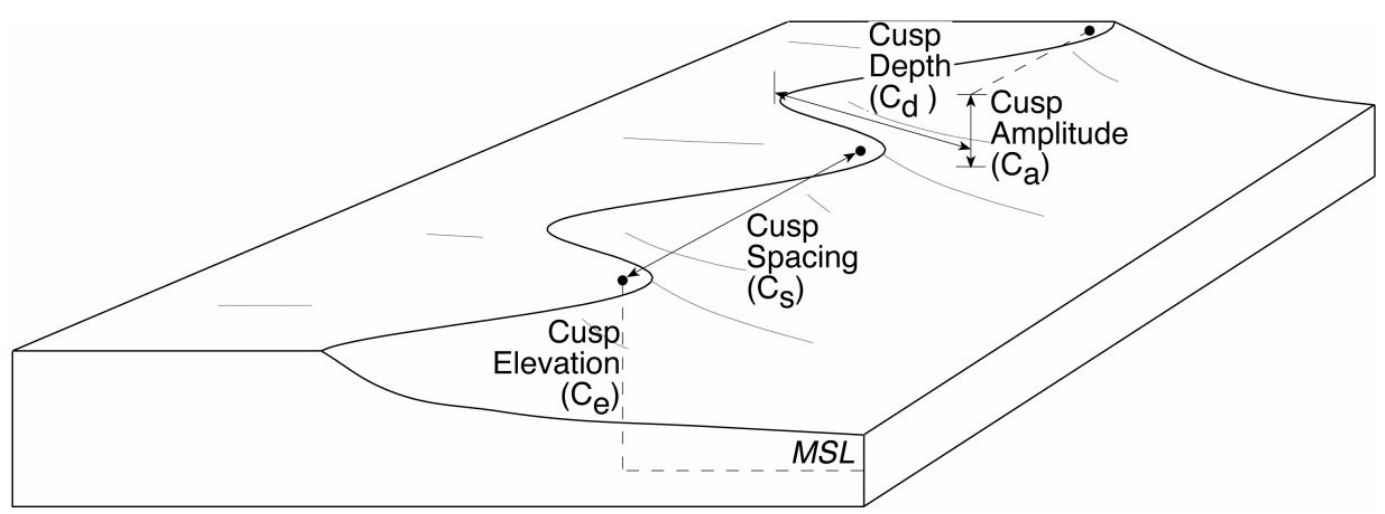

Figure 2.3: Cusp parameters showing the relationships between cusp elevation, depth, spacing and amplitude. From Nolan et al. (1999).

\section{ii. Morphological Adjustment}

Morphological adjustment of MSG beaches to changes in wave energy is markedly different to sandy beach adjustment. Sandy beach morphological response has been modelled by Short (1979). Short's morphodynamic model argued that beaches are in a dynamic equilibrium between erosional and accretionary states, and their profile shape reflects which stage in this cycle they are in (Short, 1979). Models of sandy beach response that are based on the 'Bruun Rule' (Bruun, 1962) suggest that beach response to changes in wave energy or sea level, whether temporary (e.g. storm) or permanent, involves the adjustment of the entire beach profile where sediment is removed from the back beach area and moves offshore. This is part of a negative feedback loop in which entire beach profiles flatten to dissipate wave energy further offshore. Post event, under normal wave conditions, sediment is re-circulated back onshore and is stored in the backbeach area, often as dunes (Nolan et al., 1999).

MSG beaches do not adjust their entire profiles in this manner. Gravel is not re-circulated between the nearshore and the foreshore, meaning cross-shore sediment transport is a one way system. Gravel is transported offshore and subsequently removed from the system (Kirk, 1980). Nearshore currents are not strong enough to create bar-rip systems capable of shifting gravel size sediment, so gravel generally settles offshore and may be buried by finer sediment over time. Beach stability 
and morphology in MSG systems is therefore generally dependent on a continual longshore sediment supply.

MSG beaches respond to sea level rise by landward migration through rollover; where berms are overtopped, sediment is deposited on the landward berm surface. This is generally combined with erosion of the lower foreshore, which creates a concave foreshore with a steep scour face landward and a low, flatter terrace to seaward (Dawe, 2006). To return to the accretional profile stage, MSG beaches require continual longshore sediment transport at rates operating faster than offshore sediment loss.

Drift aligned MSG beaches will also adjust their morphologies alongshore relating to changes in the wave energy regime. This may be observed through the adjustment of smaller scale rhythmic features such as cusps, or through differential erosion and accretion where one end of an embayment may be subject to scouring, and the other, deposition in response to spatial variations in wave-shoreline interactions. This is important to the current research project as the Eastbourne shoreline is situated in a littoral transport cell subject to spatially variable wave energy.

\section{iii. Sedimentology}

Grain size distribution has been examined in international MSG beaches in Sussex (Horn and Walton, 2007) and Chesil Beach (Bird, 1976) in the UK, as well as in New Zealand in Hawke's Bay (Marshall, 1929), Canterbury (Kirk, 1967), Wellington's south coast (Matthews, 1982; Jennings and Shulmeister, 2002) and Kaikoura (McLean, 1970; Dawe, 1997, 2001). Sediment texture patterns in MSG patterns are complex, with variations in sediment size spanning up to three orders of magnitude in a single profile (Horn and Walton, 2007). They share common characteristics with both sand and gravel beaches (Zenkovich, 1967), and as such, sediment distributions are generally shown to be bimodal or polymodal. This wide range of sediment sizes has led to investigations 
into whether MSG beaches display sediment size grading patterns both along and cross shore. The most common longshore grading pattern is a linear series where particle dimensions decrease alongshore with distance from a source due to selective sorting processes and/or clast attrition (Pettijohn and Ridge, 1932). Cross-shore sediment size grading is also observed in MSG beaches. Bluck (1967) has identified four zones of sediment size assemblages cross shore along gravel beach profiles these are:

1. A large disk zone at top of the beach;

2. An imbricate zone below the large disc zone above mid tide level;

3. Infill zone;

4. Outer framework zone comprised of spherical sediments.

MSG beaches, however, often lack the imbricate and outer frame zones identified by Bluck (Shulmeister and Rouse, 2003). Marshall's (1929) assessment of a $65 \mathrm{~km}$ stretch of beach north of the Mohaka River in Hawke's Bay showed a linear series where median sediment size decreased from medium pebbles $(25.4 \mathrm{~mm})$ to coarse sand $(0.59 \mathrm{~mm})$ and sorting increased with distance from the sediment source, which was attributed to selective transport processes. A different distribution pattern was found by Kirk (1967) on MSG beaches in Canterbury, where a longshore distance - particle size relationship was not present. Instead, these beaches instead showed a large size range which remained constant at all points sampled along the entire stretch of beach (Kirk, 1967).

The MSG beaches at Kaikoura studied by McLean (1970) and later by Dawe (1997, 2001), displayed neither a linear series, nor a random distribution pattern of grain size grading. A cyclic variation series was favoured, in which sediment size varies between zones of sand, mixed sand and gravel, and pure gravel. All of the above findings highlight the significant variability in grain size distributions present in mixed sand and gravel beach systems. 
Although this study is morphology based, the findings of the research presented above are pertinent to the study area because variable grain size leads to different morphological features in a littoral system. This is due to the relationship between foreshore slope and grain size on MSG beaches (McLean and Kirk, 1969).

\subsubsection{MSG Beach Processes}

\section{i. Wave processes}

Wave energy is generally the dominant force acting on MSG beaches. Other processes include aeolian and biological processes, but are much less significant from a geomorphic perspective. High incident wave energy combined with steep foreshore slopes mean that flow energies per unit area of foreshore are generally very high (Kirk, 1980). The absence of a distinctive surf zone in MSG beaches minimises offshore shoaling and associated energy dissipation, allowing wave propagation further landward before breaking occurs.

It has been shown that there is a correlation between wave steepness and ability to accrete or erode where beach cut and fill has been attributed to wave steepness values lying either side of a critical deep water wave steepness of $\mathrm{H} / \mathrm{L}=0.03$ (in models) or $0.005-0.01$ (from field observations) (Saville and Watts, 1969). Low wave steepness is associated with accretion, and higher wave steepness values are associated with beach erosion. Kirk $(1975,1980)$ noted that this wave steepness model does not adequately describe the wave dynamics for the beaches of the South Island's east coast. He has suggested the timing of wave trains is an underestimated contributor to the stability of a MSG shoreline, as wave train variability produces complex patterns of runup length and velocity, which in turn may lead to erosion or accretion of a particular shoreline regardless of wave steepness (Kirk, 1980). 
Once waves reach the breakpoint step of an MSG beach, breaking occurs in the form of plunging and surging at high tide, and plunging and/or reflection off the nearshore face at low tide. Kirk (1975) has suggested that between $20-60 \%$ of wave energy is transferred into swash, with the remainder reflected offshore. These swash processes are responsible for the majority of sediment transport and are divided into runup/uprush and backwash components. Uprush swash motions are short duration high velocity movements of water in a landward direction. Velocity and wave energy are high immediately following wave breaking, but are rapidly reduced through friction and infiltration (Anthony, 2009). The backwash component is a weaker low velocity motion responsible for transporting water back offshore.

These runup and backwash processes for a MSG beach in Kaikoura have been examined by Kirk (1975), who measured uprush and backwash velocities for a range of wave energy conditions from $\mathrm{H}=0.3-2.4 \mathrm{~m} ; \mathrm{T}=7.5$ 11.0s. Mean uprush velocities were shown to be $168.0 \mathrm{~cm} / \mathrm{s}$, compared to mean backwash velocities of $140 \mathrm{~cm} / \mathrm{s}$ (Kirk, 1975). This difference in velocity results in decreasing capacity of backwash waves to re-entrain coarser sediment, leading to the deposition of coarse gravel in the upper foreshore at the limit of swash runup.

Of paramount importance to this study are the longshore sediment transport processes that operate in coarse beach systems. Kirk (1980) has stated that longshore sediment transport in MSG beaches occurs as beach drifting in the swash zone and is dependent on the swash wave energy differences as discussed above, in combination with the angle of wave approach.

\section{ii. Factors that influence transport processes}

Mason and Coates (2001) have identified first and second order factors that influence transport processes in MSG systems. The first order factors are hydraulic conductivity, infiltration and groundwater, wave reflection 
and threshold of motion, and the second order factors are clast shape, tidal range, specific gravity, armouring and chemical processes (Mason and Coates, 2001).

The processes responsible for individual grain transport on of gravel beaches are saltation, traction-bedload and sheetflow, with suspension of fines also playing a substantial role in MSG beaches (Buscombe and Masselink, 2006). These transport modes affect gross sediment sorting and are functions of hydraulics and swash hydrodynamics, with individual grain transport also being influenced by small scale mechanical factors related to size and shape variation of grains (Buscombe and Masselink, 2006).

Gravel beach research has been predominantly focused on beach systems within an open coast environment. The study site for the present project is, as aforementioned, within a harbour and therefore sediment transport systems, and marine processes in general would behave differently than the beaches reviewed in much of the literature. The open coast is subject to multiple wave types impacting the shoreline from varying angles depending on the location and strength of different swell sources and localised wind wave conditions, as well as tidal regimes and other currents such as rips or undertow currents. Conversely, fetch limited coastal environments such as Wellington Harbour are sheltered from particular wave processes and therefore are influenced by different transport processes and exhibit different beach morphologies.

\subsection{Sediment transport in a fetch-limited setting}

Many fetch-limited settings are only influenced by locally generated wind waves, but at other sites, the input of ocean waves is highly significant in determining the morphology of an estuarine beach setting (Nordstrom, 1992). The energy of the waves generated in a fetch-limited setting is significantly less than that of waves generated in open oceans, and the location and orientation of an inlet entrance can determine whether 
oceanic swell waves will affect the morphology of the inlet beach systems (Jackson and Nordstrom, 1992). The depth at which wave and nearshore bottom interactions occur depends on wave length. As ocean waves reach the entrance of a fetch-limited system like an estuary, much of their energy is lost through refraction and shoaling, and the effectiveness of the waves becomes increasingly dependent on factors such as beach orientation (Nordstrom, 1992).

Longshore currents operating in fetch-limited environments generally correspond to local wind directions (MacDonald, 1989), but refracted ocean waves can complicate this relationship (Nordstrom, 1992). These currents are established when waves encounter the shore at an oblique angle, forcing an alteration of the water motion with some alignment towards the shore, whilst the remainder of the water is directed alongshore.

\subsection{Beach Morphology in fetch-limited settings}

Morphology dictates where wave interaction occurs, which in turn alters morphology. The study site is situated in a fetch-limited environment, exhibiting the characteristics of a mixed sand gravel system.

Sandy beach morphology in fetch-limited settings has been the focus of numerous studies (e.g. Norstrom, 1992; Wright and Short, 1984; Lippman and Holman, 1984; Kennedy, 2002). These beaches are typically narrow and featureless with strong tidal influences. The typical sandy beach morphotypes identified by Hegge et al. (1996) for low energy fetch-limited environments (Fig. 2.4 ) range from concave to stepped morphology on spatial scales of $<60 \mathrm{~m}$. These variances are due to a combination of sediment type and hydrodynamic parameters. These morphologies are also related to the positioning of estuarine/harbour beaches relative to harbour/estuary entrances. Kennedy (2002) has examined the variation of estuarine beach morphology in relation to their exposure to open-ocean influences in a harbour setting. His findings suggest that beaches that are 
more exposed to oceanic swell may respond similarly to open ocean beach systems and adopt steep and generally concave profiles (Kennedy, 2002).

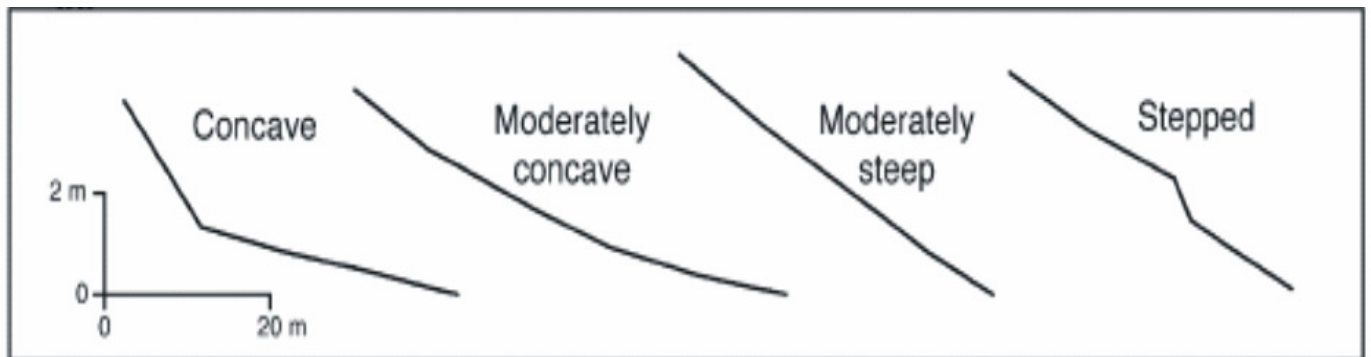

Figure 2.4: Low energy beach morphotypes from Hegge et al. (1996).

Though few studies have been conducted on MSG beaches in fetchlimited environments, some research has been conducted in environments that may serve as a proxy for such systems. A small amount of literature has focussed on the morphological response and longshore transport of mixed sediment beaches operating within lacustrine environments (e.g. Pickrill, 1985; Dawe, 2006). This research is relevant to the present study, as lakes are also fetch-limited environments, with similar sediment transport processes operating to those found in a harbour or other estuarine setting. Dawe (2009, pers. comms.) has suggested that MSG beach morphology in a lacustrine setting is similar to that of an MSG beach in a fetch limited marine setting. MSG beach morphology in lacustrine fetch-limited environments differs from open oceanic MSG beach morphology (as in Kirk, 1980), mainly in terms of the spatial scale that these respective systems operate on. Lacustrine MSG beaches are typically narrow and subject to lower wave energy than oceanic MSG beaches. A MSG beach operating in a harbour setting could be presumed to share some of the morphological characteristics of a lacustrine MSG beach setting. These are beach width, steepness and berm presence. Though their morphologies are very similar, morphological features of MSG beaches in a fetch-limited harbour environment would be expected to be on a larger scale than lacustrine features. This is because lacustrine environments are not exposed to open ocean waves. 


\subsection{Summary}

As outlined above, the processes that govern the morphological development of MSG beaches in fetch-limited environments are complex and provide a number of unanswered questions to investigate. Past studies have conducted research on sites that are either fetch-limited or MSG. Though these that may serve as proxies for the study area, there remain vital gaps in the knowledge of MSG beach morphology and response to forcing mechanisms found in fetch limited environments. The present research has been conducted on exactly such an environment and therefore will present vital insights into the poorly understood, yet impactful dynamics of MSG systems. 


\section{Chapter Three: Regional Setting}

\subsection{Introduction}

This research has been conducted in the coastal suburb of Eastbourne, on the eastern shore of Wellington Harbour, lower North Island, New Zealand (Fig. 3.1). This area consists of a series of embayed beaches separated by rocky headlands, where residential development is concentrated on a cuspate foreland at Eastbourne and extends up the adjacent hills (Fig. 3.2). This chapter provides a description of the study site at Eastbourne by examining the geology, geomorphology, climate and anthropogenic history of the area.

\subsection{Wellington Harbour}

Wellington Harbour is a micro-tidal semi-enclosed embayment located at the southern end of New Zealand's North Island (41 '16' S/Long. 174 ${ }^{\circ} 51^{\prime}$ E) (Fig. 3.1). It is $85 \mathrm{~km}^{2}$ in area with a maximum fetch of $14 \mathrm{~km}$ (Quayle, 1984) and a maximum depth of $32 \mathrm{~m}$ (Fig. 3.4) (Pallentin et al., 2009). Its entrance, located in the south, is $8.5 \mathrm{~km}$ long with a mean width of $2.9 \mathrm{~km}$ (Carter, 1977). Tidal currents at the Harbour entrance have a maximum flow speed of between 19 and $46 \mathrm{~cm} / \mathrm{s}$ which though powerful enough to move sand intertidally, is hypothesised to be too weak to instigate coarse sediment transport alone (Carter, 1977). On its northern boundary the Hutt River delivers sediment from the Rimutaka Ranges. The western flank is dominated by the Wellington Fault scarp rising to $200 \mathrm{~m}$ elevation, and on the eastern flank, between the Eastbourne shoreline and Ward Island, a platform unofficially named the Eastbourne Platform occurs with an average depth of $12 \mathrm{~m}$ (Fig. 3.4). 


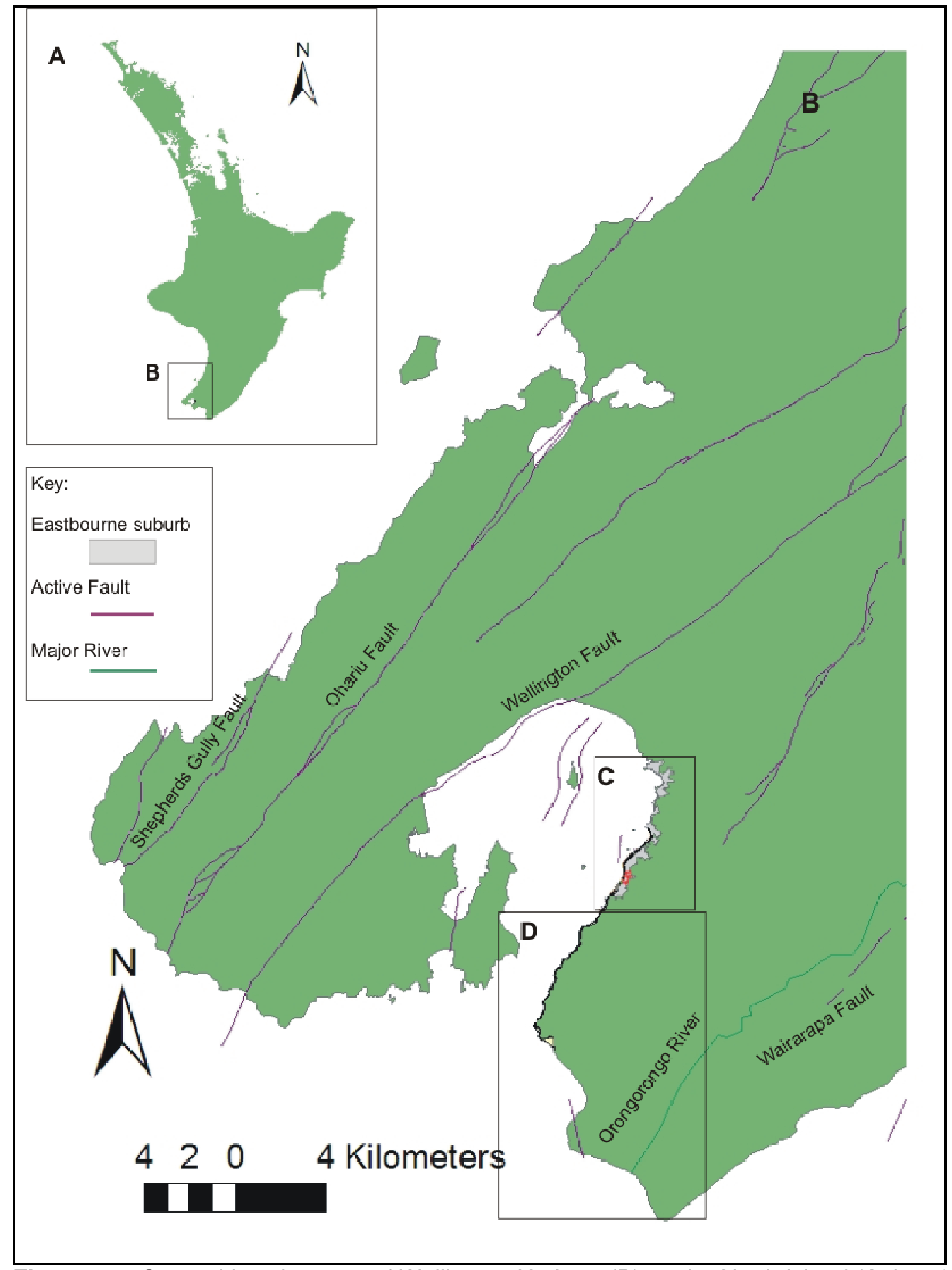

Figure 3.1: General location map of Wellington Harbour (B) on the North Island (A, inset) showing the locations of the Eastbourne (C) and Pencarrow (D) Coasts, and the locations of the Wellington, Wairarapa, Ohariu and Shepherds Gully Fault-traces. 


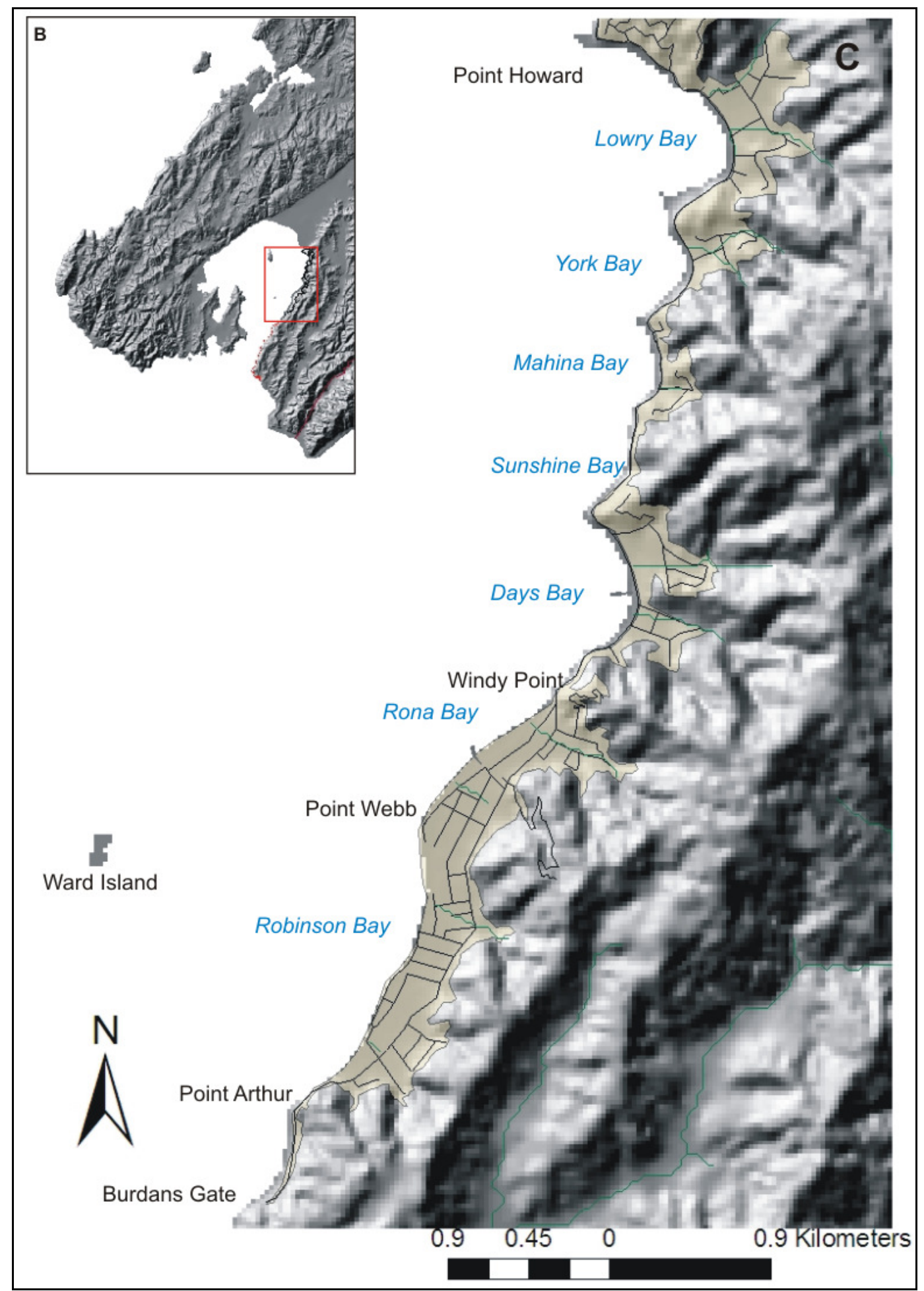

Figure 3.2: Map of central Eastbourne and the Northern Bays showing bay locations, location of development and topography of the eastern hills. 


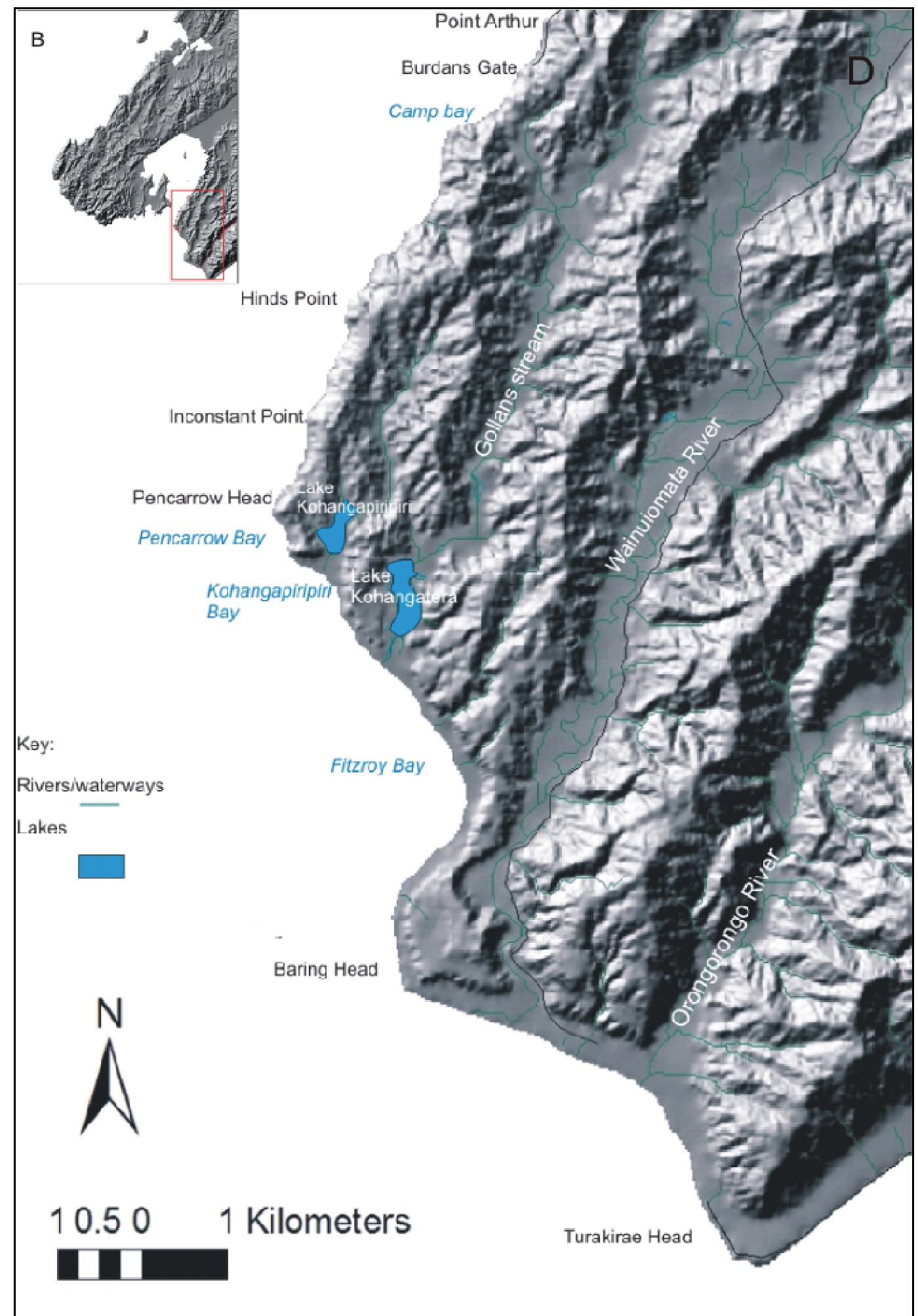

Figure 3.3: Location map of the Pencarrow Coast between Turakirae Head and Burdens Gate. Map shows location of the Orongorongo and Wainuiomata Rivers and Gollans Stream and Lakes Kohangapiripiri and Kohangatera. 


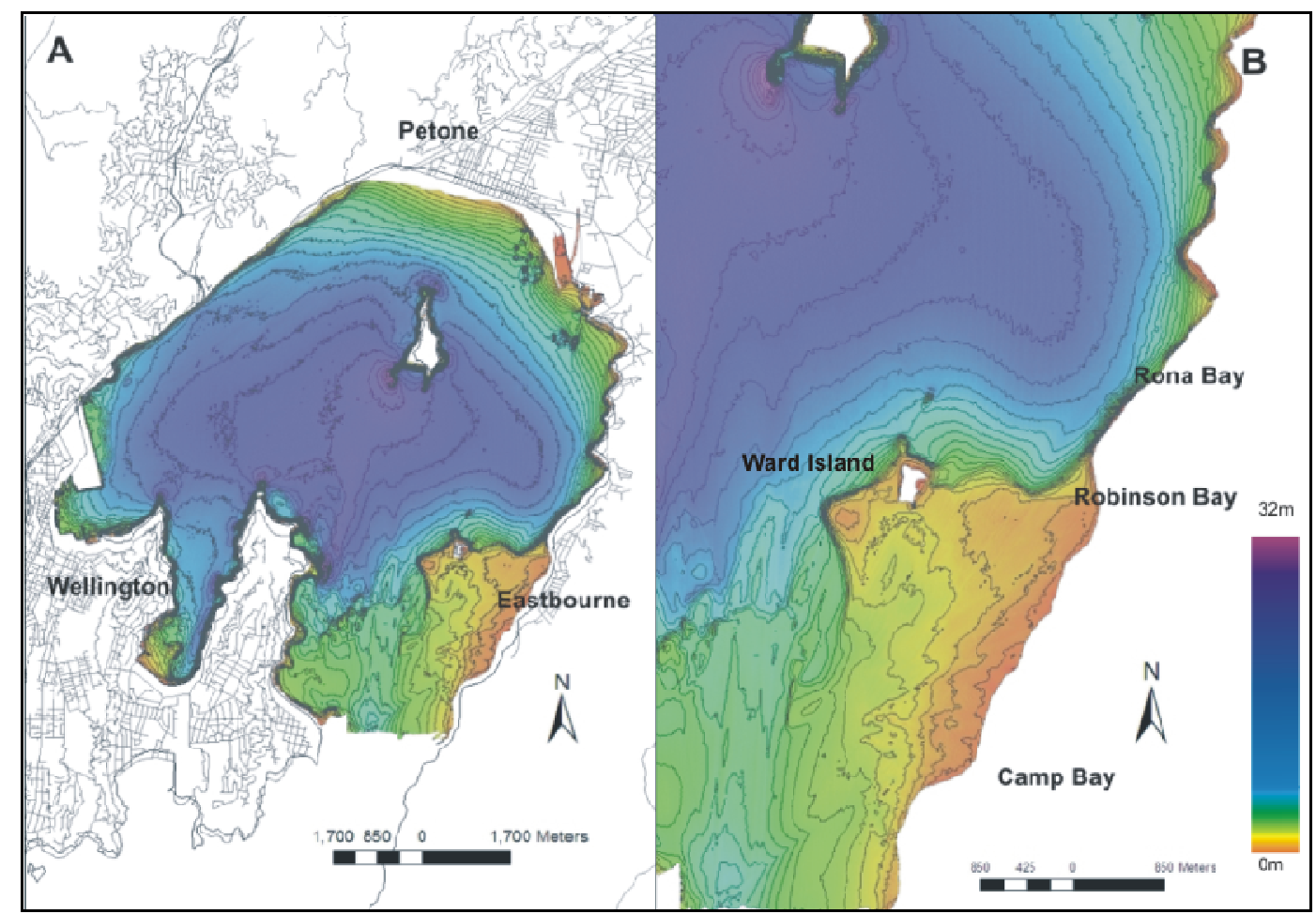

Figure 3.4: Wellington Harbour sun-illuminated bathymetry grid combined with $1 \mathrm{~m}$ contours (A) and detail of eastern harbour bathymetry showing the shallow Eastbourne Platform between Ward Island and the Eastern shoreline (B) (after Pallentin et al., 2009).

\subsection{Geological setting of the Wellington Region}

\subsubsection{Basement Geology}

Mesozoic greywacke and argillite are the dominant lithologies of the Wellington Region (Stevens, 1974). On the eastern side of the harbour these have been identified as being part of the Rakaia Terrain, a series of sandstone-mudstone sequences with poorly bedded sandstone and minor conglomerate, mudstone, chert, basalt and infrequent limestone (Begg and Johnston, 2000). This is part of the Torlesse Supergroup formed between the Early and Late Triassic Periods. The Wairarapa Fault, the fault scarp of which the Orongorongo River follows, (Fig. 3.1) marks the boundary between the Rakaia Terrain and the Pahau Terrain (Begg and Johnston, 2000). This boundary is defined by a $20 \mathrm{~km}$ wide zone of earthquake-fractured and deformed rock known as the Esk Head Belt (Begg and Johnston, 2000). Late Pleistocene and Holocene sediments are present in the Hutt Valley, the Wellington Harbour, and in depressions and other low-lying areas in the Region (Begg and Johnston, 2000). 


\subsubsection{Tectonic setting}

The Wellington area is comprised of westward tilting blocks separated by Pliocene to Recent fault systems which has led to the development of steep relief that has been extensively fluvially dissected (McConchie et al., 2000). The region is intersected by five major active right-lateral strike-slip faults that are part of the North Island Fault System (Fig. 3.1). These are the Wairarapa, Wellington, Ohariu, Shepherds Gully/Pukerua, and Wairau faults, which have average, lateral slip rates that range from 1 to $10 \mathrm{~mm} / \mathrm{yr}$ (Van Dissen and Berryman, 1996) These faults have been responsible for high magnitude ( $>8 \mathrm{MM}$ ) seismic events throughout the Holocene era, the most recent being the 1855 Wairarapa earthquake, a 8.2MM event located on the Wairarapa fault at a depth of $25 \mathrm{~km}$, with the epicentre thought to be at $41.4^{\circ} \mathrm{S} 174.5 \mathrm{E}^{\circ} \pm 0.5^{\circ}$ (Downes, 2005).

These faults are a response to tectonic stress caused by Wellington's position on to the Pacific/Indo-Australian plate boundary. Due to the convergent and dextral strike-slip nature of the plate boundary at this location, significant co-seismic uplift and horizontal displacement has occurred throughout Wellington Harbour and the surrounding region (McSaveney et al., 2006). This uplift presents itself in a number of obvious landscape features, including the uplifted beach ridges at Turakirae Head and widespread exposure of basement rock, and the distinct Wellington fault scarp on the western border of the harbour. The most recent large seismic event in this region was the 1855 Wairarapa Earthquake, that uplifted and tilted the Wellington block westward, a movement that is characteristic of faults in this area, which have return periods of $\sim 500$ to 5000yr (Van Dissen and Berryman, 1996). Measurements from raised wave-cut platforms at Cape Turakirae have indicated that, during this event, there was a maximum of $6.5 \mathrm{~m}$ vertical uplift, and measurements from inside the harbour entrance indicate the beach at Eastbourne was raised by approximately $2.1 \mathrm{~m}$ (McSaveney and Pillans, 1996). The geological and seismic characteristics of the region have significantly influenced the study area in the past. Past seismic events are known to 
have changed the relative sea-level and sedimentation regimes of the area, as well as causing the removal of sediment from previously subtidal areas (Matthews, 1980a, Carter, 1977.)

\subsection{Geomorphology of Eastbourne and Pencarrow coast}

\section{i. Eastbourne and the Northern Bays}

The Eastbourne coast, as defined in the present study, extends from Point Howard in the north to Burdans Gate in the south, covering a distance of $8.6 \mathrm{~km}$ (Fig. 3.2). This stretch of coast consists of a series of embayed beaches separated by rocky headlands. The bays between Point Howard and Central Eastbourne are Sorrento, Lowry, York, Mahina, Sunshine and Days Bay (Fig. 3.2). North of Days Bay, the beaches are narrow and sediment starved with angular yellow brown coloured greywacke cobbles and pebbles and thin veneers of sand in the foreshores. Days Bay Beach is a $750 \mathrm{~m}$ long crescentic embayment intersected a $140 \mathrm{~m}$ long wharf near the centre of the Bay (Carter and Gibb, 1985). North of the wharf the beach is narrow and sandy with a $100 \mathrm{~m}$ long section of sea wall in the backbeach area, adjacent to the wharf. South of the wharf, the beach is wider $(\sim 30 \mathrm{~m})$ and grades from sand in the middle of the Bay, to gravel in its southern reaches.

The main residential development in the study area is on the $2.5 \mathrm{~km}$ by $300 \mathrm{~m}$ cuspate foreland at Eastbourne bounded to the north by Rona Bay, to the south by Robinson Bay and to the east by greywacke hills of approximately $300 \mathrm{~m}$ elevation (Fig. 3.2). This foreland has developed over the last approximately $2.5 \mathrm{Ka}$ as alternating sand and gravel supplies have migrated north from Pencarrow by a combination of subaerial and marine transport mechanisms (Gibb, 2005).

Rona Bay, north of Point Webb (Fig. 3.2), is approximately $1 \mathrm{~km}$ in length, with a mix of sand and gravel on the beachface and extensive dune fields in the backbeach zone. South of Point Webb is Robinson Bay, the main 
study site of this research project. More specifically, the northern end, adjacent to H.W. Shortt Recreation Ground, was where most of the research was conducted for this study (Fig. 3.2). Robinson Bay is approximately $1.6 \mathrm{~km}$ long and has a concrete sea wall that spans $1 \mathrm{~km}$ of its length. It is an extensive mixed sand and gravel system that has been accreting since 1985, following erosion problems in earlier decades (Gibb, 2005). Two prograding sections are present in the bay, which will be discussed in detail in Chapters Five and Six. The southern extent of Robinson Bay is punctuated by Lions Rock at Point Arthur (Fig. 3.2), south of which there is a stretch of gravel beach that extends to the end of the public road network at Burdans Gate, the southern end of the Eastbourne Coastline.

\section{ii. Pencarrow coastline}

The Pencarrow Coast which, for the purposes of this study, includes the $17 \mathrm{~km}$ of coast that runs from Turakirae Head in the south, to Burdans Gate in the north (Fig. 3.3), is primarily composed of steep gravel beaches and greywacke headlands. This coast is intersected by two major rivers, the Orongorongo and the Wainuiomata, and two smaller streams Cameron Creek and Gollans Stream, both of which are fronted by lakes Kohangapiripiri and Kohangatera respectively (Fig. 3.3). The fieldwork component of this research extends as far south as Kohangapiripiri Bay, $9.8 \mathrm{~km}$ from the Orongorongo River, where an extensive gravel barrier has formed at the mouth of Gollans Stream, damming Lake Kohangapiripiri (Fig. 3.3). The next embayment to the north is Pencarrow Bay (Fig. 3.3) another large gravel beach, the northern headland of which is Pencarrow Head. North of this, the coastline is composed of smaller gravel filled pocket beaches and straight narrow stretches of shoreline through to Camp Bay, which is the last extensive embayment south of Burdans Gate (Fig. 3.3). This part of the region is primarily farmland with a narrow gravel road dividing the shore and the hills. 


\subsection{Sedimentological Setting}

Eastbourne and Pencarrow's beaches are comprised of Triassic to Jurassic age greywacke and argillite gravel and sand, reflecting the aforementioned bedrock parent material (Matthews, 1980). This sediment comes from multiple sources, but the contributions of rivers in Pencarrow are considered to be the dominant sediment contributors to the coastline (Matthews, 1980a; Carter, 1977).

\subsubsection{River sources}

Four north-east oriented valleys are located on the Pencarrow coast at the updrift part of the Pencarrow/Eastbourne littoral cell (Matthews, 1980a). The two smaller ones contain Gollans stream and Cameron Creek, fronted by Lakes Kohangapiripiri and Kohangatera respectively. These smaller waterways are enclosed by gravel beach barriers, and sediment contribution of these catchments to the coast is thought to be mostly through percolation, and therefore insignificant to the overall system (Matthews, 1980a). The dominant sediment source for the Eastbourne/Pencarrow Coast under present conditions is the Orongorongo River, a braided river system, which runs for $32 \mathrm{~km}$ from the Rimutaka Ranges (Hastie, 1989). Sediment from the Orongorongo has both fine and coarse fractions. The coarse fraction is thought to be being supplied at a rate of $\sim 7,200 \mathrm{~m}^{3} / \mathrm{yr}$, whereas the fine fraction is distributed onto the continental shelf at rates in the order of $15,000 \mathrm{~m}^{3} / \mathrm{yr}$ (Matthews, 1980a). Unlike the Orongorongo, the Wainuiomata River is thought to contribute predominantly fine sediment onto the shelf at an estimated rate of over $660 \mathrm{~m}^{3} / \mathrm{yr}$ (Hastie, 1989).

\subsubsection{Re-deposition from offshore sources}

Matthews (1980a) has suggested that fine sand and silt sized material accumulated on the harbour floor from both southerly and northerly sources, contributing to the sedimentation of the study area through 
indirect mechanisms (Goff et al., 1998). From the south, rivers and coastal erosion have been estimated to have contributed approximately $40,000 \mathrm{~m}^{3} / \mathrm{yr}$ to the sea floor in the Harbour entrance between 1849 and 1951 (Carter, 1977). Whereas in the north of the Harbour, the Hutt River supplies sand and silt resulting in seafloor accumulation of $<60 \mathrm{~mm} / \mathrm{yr}$ (Goff et al., 1998). It was found that sand from the south are dominantly re-deposited in Eastbourne by tidal currents in combination with southerly swell and storm-driven currents (Carter and Lewis, 1995).

\subsection{Climate setting}

\subsubsection{Climate Overview}

New Zealand's climate in general reflects its mid-latitudinal setting and the strong influence of the Southern Ocean. The prevailing weather pattern consists of west-east flowing anticyclonic pressure systems that migrate across the landmass approximately every week. These are alternated with troughs of low pressure, that extend northward from eastward moving cyclonic depressions south of the New Zealand landmass (Metservice, 2009). The anticyclones produce settled weather with low rainfall and have trajectories that change on seasonal timescales. The low pressure systems are often associated with northwest to southeast orientated cold fronts and unsettled weather patterns, which include periods of increased northwesterly winds and cloudiness, as well as cold showery southwesterly winds with showers (Metservice, 2009).

These weather patterns are amplified in the Wellington Region because of its proximity to the Cook Strait, and because of orographic channelling of northerly winds by the Tararua and Rimutaka Ranges (Quayle, 1984). This produces the dynamic and highly variable weather characteristic of the region. The climatic variables of greatest importance to this study are wind and rainfall, as wind generates the waves responsible for sediment transport along the coastline, and rainfall is a major factor in sediment contribution onto the coastal plain from river catchment sources. 
Additional to providing information on wind and rainfall, the following sections will also provide more detailed information on other climate conditions, such as temperature and sunshine hours, which are assumed to have a minor effect on this study. Finally, this section will provide information on large climate events that occur in this region and their effects. Events covered include tropical cyclones, rainstorms and sever winds. As these events have the potential to move large amounts of sediments over short time periods, understanding their influence on the study area is of great importance.

\section{i. Winds}

Wellington's winds generally tend from the north $\left(320-040^{\circ}\right)$ and south $\left(140-220^{\circ}\right)$ (NZ Meteorological Service, 1981), with northerlies being the predominant wind direction, accounting for 50-60 percent of all winds (Fig. 3.5). These are shown to tend north-westerly when especially strong or when air pressure is unstable (Quayle, 1984). Annual average wind direction and speed for the for the period 1960 - 2009, has been taken from the Wellington Airport meteorological monitoring station, which serves as a proxy for Eastbourne as they are both low altitude coastal sites that are exposed to northerly and southerly airflows. The data from this station, presented in Figure 3.6, shows the dominant north-south wind flow, with wind speeds in excess of $20 \mathrm{~km} / \mathrm{h}$ occurring over 50 percent of the time whilst calm conditions occur only four percent the time. The strong winds in this area are gusty in the lower flow levels because of topographical forcing (Tait et al., 2002). Wind speed is spatially variable throughout the Wellington Region ranging from average speeds of $42 \mathrm{~km} / \mathrm{h}$ at Mount Kaukau at an elevation of $425 \mathrm{~m}$ amsl, to $27 \mathrm{~km} / \mathrm{h}$ at Wellington Airport closer to sea level, with lower speeds in parts of the Wairarapa and Kapiti Coast (Tait et al., 2002). There is minor seasonal variation in wind speed, with spring being the windiest season. Wind direction is more seasonally variable, with the southerly winds become more influential during the winter months of May through to August (Quayle, 1984). During 
the winter season, southerly winds account for 30 percent of all winds, and the frequency of large scale storm events is greatly increased.

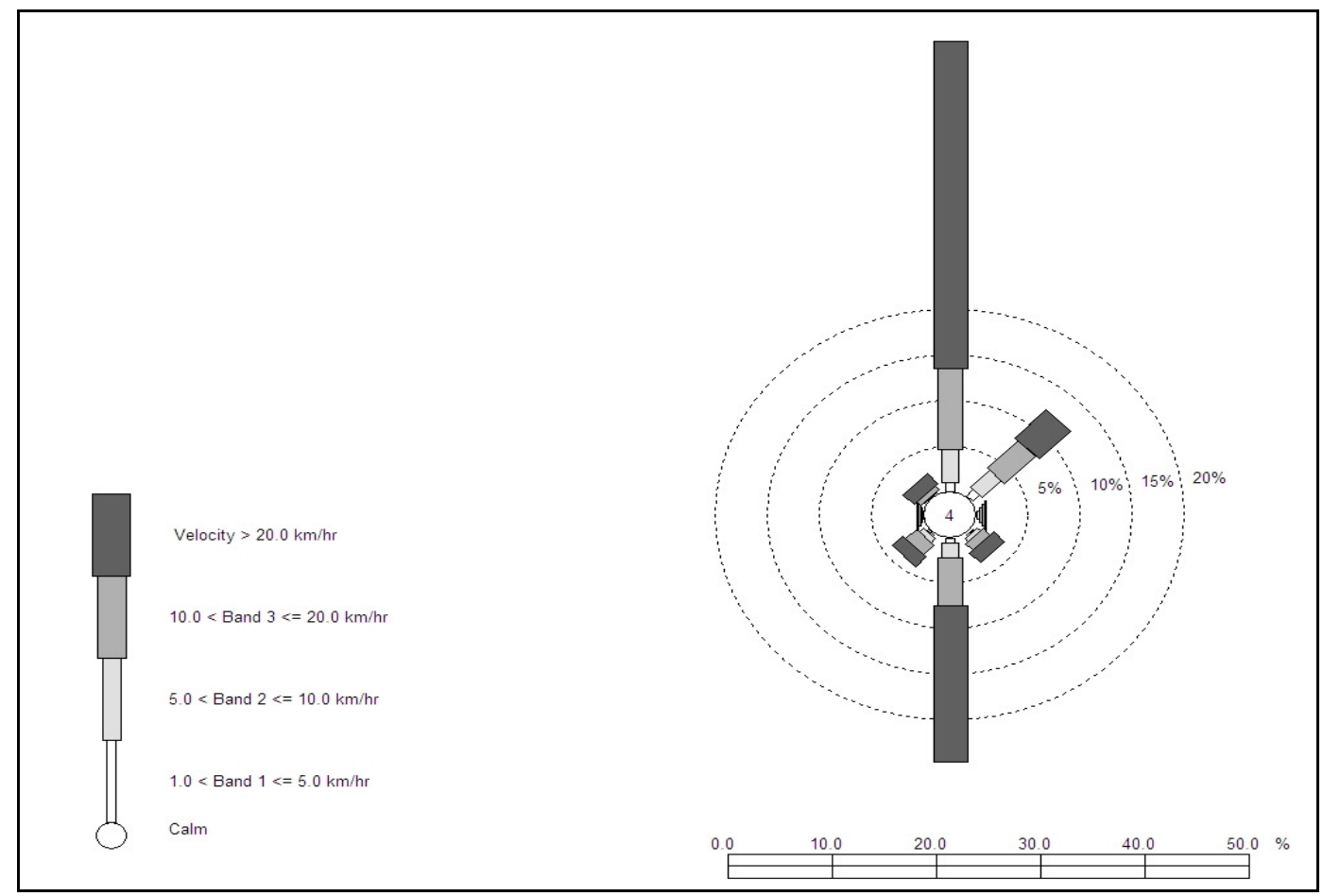

Figure 3.5: Wellington Airport Wind direction and wind speed from 1-Jan-1960 to 25Aug-2009. Wind direction is either due north or south $\sim 70 \%$ of the time and $>20 \mathrm{~km} / \mathrm{hr}$ for over $50 \%$ of the days in this period.

\section{ii. Rainfall}

Average annual rainfall for the Wellington Region is $1200-1400 \mathrm{~mm}$ with maximum annual rates of $2400 \mathrm{~mm}$ occurring in the Rimutaka Ranges and $3200 \mathrm{~mm}$ in the Tararua Ranges (Tait et al., 2002). There is significant seasonal variation in rainfall distribution in the region with winter producing significantly higher average rainfall rates than summer. Readings from Kelburn weather station indicate that average rainfall for January is $81 \mathrm{~mm}$ and July's average rainfall is $139 \mathrm{~mm}$ (Tait et al., 2002). Annual rainfall for Wellington Airport between 1960 and 2008 (Fig. 3.6) shows annual fluctuations between $600-1400 \mathrm{~mm} / \mathrm{yr}$, with an average of $1001 \mathrm{~mm}$, and a period of higher rainfall between 1974-80. Data for this site was unavailable from 1992-95. Annual rainfall for the Orongorongo Catchment over a period from 1924 to 1974 (Carter and Lewis, 1995:465) suggests a higher annual rainfall than the regional average, at a rate of $\sim 3000 \mathrm{~mm} / \mathrm{yr}$, 
with higher variability between 1934 and 1944, and again between 1964 and 1974, peaking in 1974, which is also seen in the Airport rainfall data.

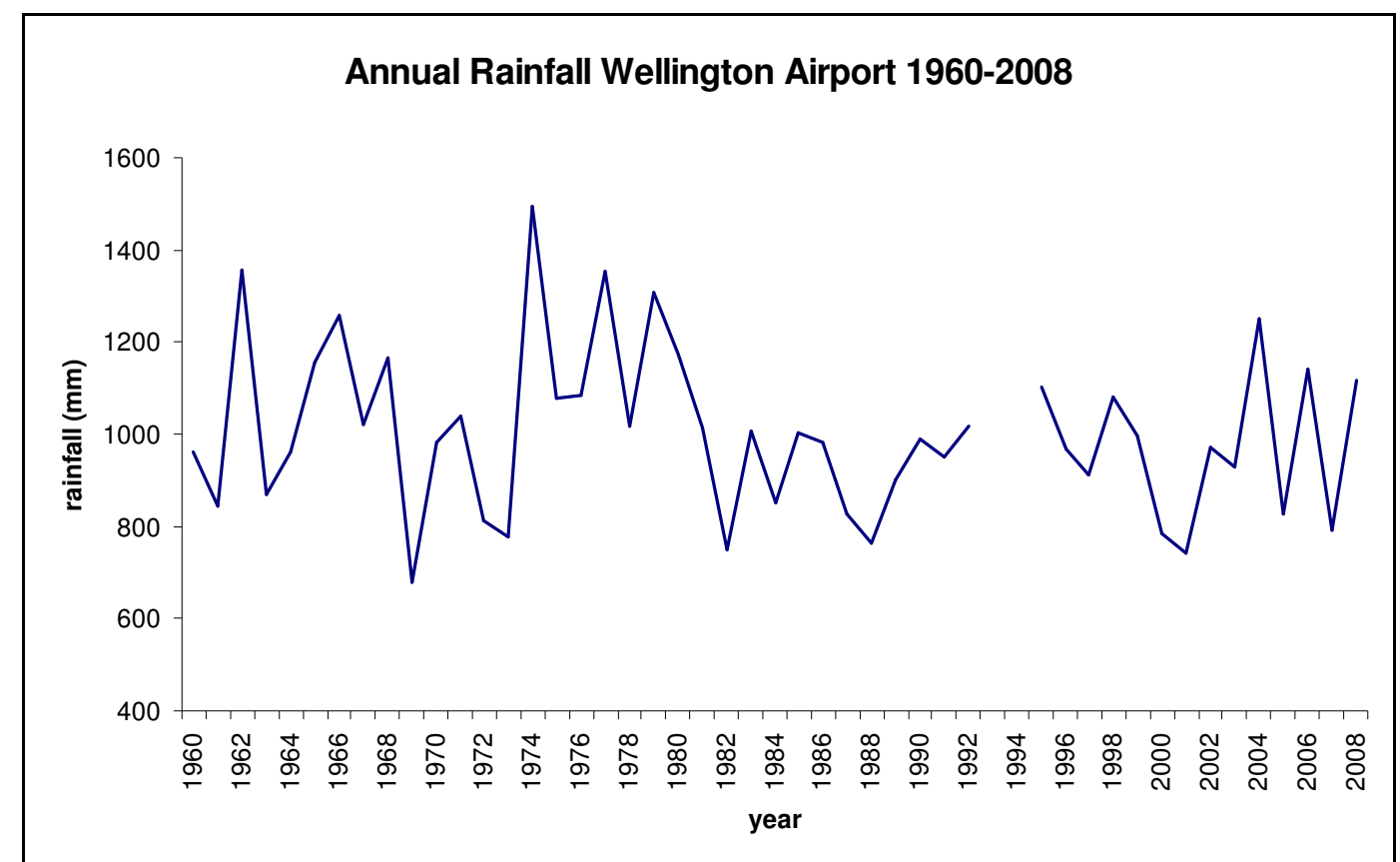

Figure 3.6: Annual rainfall for Wellington Airport between 1960-2008. Data was unavailable for the years 1992-1995.

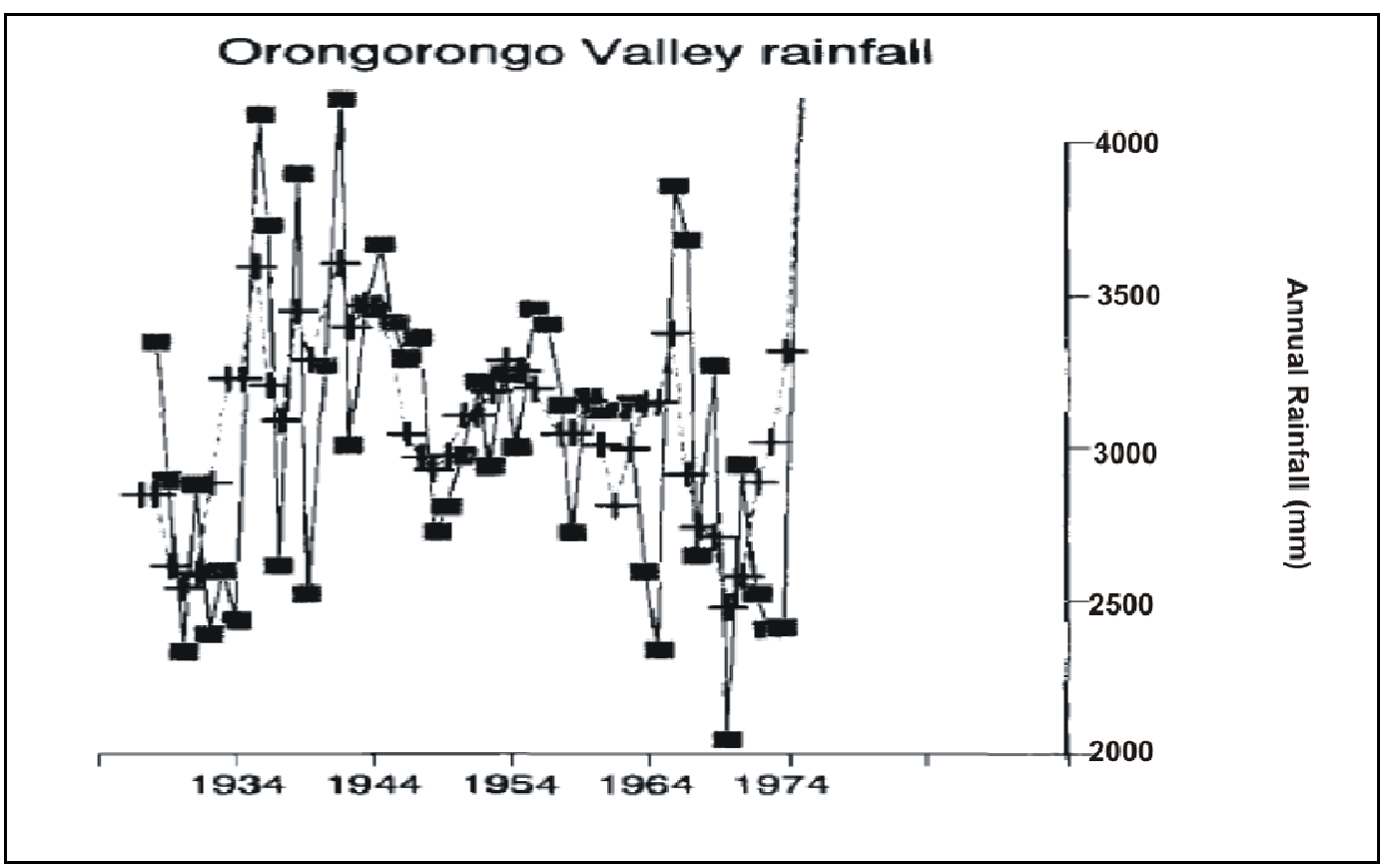

Figure 3.7: Annual Rainfall for the Orongorongo Valley between 1924 and 1974 (Carter and Lewis, 1995:465). 


\section{iii. Temperature and sunshine hours}

Being a windy, maritime climate, Wellington experiences only moderate temperature extremes and average monthly temperatures vary seasonally from minimum $8^{\circ} \mathrm{C}$ in winter to maximum $17^{\circ} \mathrm{C}$ in summer in Wellington, and $2-22^{\circ} \mathrm{C}$ in the Wairarapa, east of the Rimutaka Ranges (Tait et al., 2002). The average annual sunshine for Wellington recorded at Kelburn station is 2019 hours, ranging from 236 average sunshine hours in January to 104 in June.

\subsubsection{Low frequency high magnitude (LFHM) meteorological events influencing Wellington Harbour}

There are several interrelated meteorological hazards that affect or potentially may affect the eastern side of Wellington Harbour and influence erosion and sediment transport through Eastbourne's coastline. These are severe winds, rainstorms and (ex-) tropical cyclones. Other meteorological hazards for the area have been omitted from this research due to their low relevance to the coastline.

\section{i. Severe winds}

High winds in Wellington can be from the north or south, either as sustained high wind speeds or as gusts. Historical extreme weather events have produced winds of up to $110 \mathrm{~km} / \mathrm{hr}$ with gusts up to $198 \mathrm{~km} / \mathrm{hr}$. Both these recorded wind speeds were from Cyclone Giselle in 1968, but gusts of up to $126 \mathrm{~km} / \mathrm{hr}$ have been recorded from either northerly or southerly directions with the passing of general storms from mid latitude low pressure systems (Tait et al., 2002). Between 1990 and 2000, gust speeds in excess of $144 \mathrm{~km} / \mathrm{hr}$ were recorded four times at Wellington Airport, and the 142yr return period gust has been calculated to be $176 \mathrm{~km} / \mathrm{hr}$ at this location (Tait et al., 2002). Severe winds have the ability to cause high swells especially southerly winds as they exceedingly large fetch over which swells can develop. Additionally severe winds can lead to 
the generation of local sourced sea waves from both north and south. Both of these processes will effect the longshore transport of sediment in the study area.

\section{ii. Rainstorms}

Rainstorm events in Wellington can be the result of the passing of cold fronts or tropically-generated cyclones. Rainstorms can have two main effects on the study site: (1) they can trigger landsliding in catchments and increase fluvial erosion rates, which can increase input of sediment into the primary river channels; (2) they increase river discharge, increasing sediment transport capacity, which may result in higher sedimentation rates onto the continental shelf.

Predicted maximum rainfalls for 2, 5, 10, 20 and 50 year periods repectively have been calculated for Kelburn weather station (Table 3.1) (Thompson, 1987:13). These results have been calculated using historical rainfall data from the period 1863-1985. These data show that, for example, given a return period of ten years, a maximum daily rainfall of $110 \mathrm{~mm}$. Additionally, over a three day period $124 \mathrm{~mm}$ of rainfall would have a return period of two years.

Table 3.1: Kelburn station rainfall prediction based on hindcast data from the period 1863-1985. Predictions are given for return periods $T=2,5,10,20,50$ years. For each return period, expected maxima for a 1,2 and 3 day duration are given. Values are in $\mathrm{mm}$.

\begin{tabular}{|l|cccccc|}
\hline \multicolumn{7}{|c|}{ Kelburn station, Wellington } \\
\hline Duration & $\mathrm{T}=$ & 2 & 5 & 10 & 20 & 50 \\
\hline 1-day & & 81 & 98 & 110 & 122 & 138 \\
2-day & & 111 & 134 & 151 & 169 & 192 \\
3-day & & 124 & 149 & 168 & 187 & 213 \\
\hline
\end{tabular}

On the 20 December 1976, a greater than 50yr return period rainstorm event occurred in the Wellington Region. This event caused $153 \mathrm{~mm}$ of rain to fall within 24 hours at the Kelburn monitoring station, with a maximum of $300 \mathrm{~mm}$ occurring $5 \mathrm{~km}$ to the west (Wellington Regional Water Board, 1976). This event was caused by two moist air streams coming from the north and south respectively and merging over the Hutt 
Valley, causing rapid rise and cooling of the air masses and widespread heavy rain. This sustained heavy rain caused numerous landslides, blocking of culverts and storm water systems. These storm waters caused widespread erosion and deposition in the catchments of the waterways that drain into the Wellington Harbour.

\section{iii. Ex-tropical cyclones}

One notable cause of extreme rainfall and severe wind events experienced in the Wellington region are (ex) cyclones sourced from the tropical regions north of New Zealand (typically between $-10^{\circ}$ to $-20^{\circ}$ latitude) (Revell, 1981). (Ex) tropical cyclones are storms that include extreme wind and rain. Winds of up to $>222 \mathrm{Km} / \mathrm{h}$ are known to occur during these storms coupled with extreme rainfall and open ocean waves of up to $14 \mathrm{~m}$. Tropical cyclones are formed by positive feedback loops that occur as a result of energy release during the condensation of moisture in rising air masses over warm ocean waters (Emannuel, 2006). A return period for tropical cyclones in the Wellington Region is estimated to be three to six years (Tait et al., 2002). The effects of such an event on the study area include severe winds and rains and their effects as explained above, and storm surge which have the potential to cause extensive coastal flooding if superimposed upon already raised sea levels caused by low barometric pressure.

An example of a tropical cyclone that severely affected the Wellington Region was Cyclone Giselle, which occurred on 10 April 1968. This cyclone originated to the north west of New Caledonia. It made landfall on the $9^{\text {th }}$ April 1968, after re-intensifying north of New Zealand. The cyclone eventually settled near Cape Palliser where it caused wind gusts of $187 \mathrm{~km} / \mathrm{h}$ and waves of between 12 and $14 \mathrm{~m}$ (Harris, 1990). This event was known to have caused extensive coastal erosion in the Wellington Region, and it may be assumed that it would have transported large quantities of sediment northward through the study area. 


\subsection{Oceanographic Setting}

\section{i. Wave climate}

Waves are the dominant force acting on the Eastbourne/Pencarrow Coast (Matthews, 1980:a). The sea conditions in Wellington Harbour reflect the wind patterns of the region. The northerly is the predominant wind, but the maximum fetch for this wind direction is only $10-14 \mathrm{~km}$, which is insufficient to produce large swell waves (Hastie, 1989). Maximum northerlygenerated wave heights and periods were calculated by Hastie (1989:7) using fetch diagrams presented in Dackombe and Gardiner (1982). These results, presented in Table 3.2, show that in central Eastbourne, where the maximum northerly fetch is only $6.5 \mathrm{~km}$, a $40 \mathrm{knot}$ wind will only produce waves of approximately $1.1 \mathrm{~m}$, with $3.5 \mathrm{~s}$ wave periods.

Southerly sourced waves have a more pronounced impact on the Harbour entrance, as waves have an unlimited fetch (Pickrill and Mitchell, 1979). This allows for the generation of large swell waves up to $5 \mathrm{~m}$ with $16 \mathrm{~s}$ periods (Carter and Lewis, 1995). It is these southerly waves which are suspected to be responsible for gravel transport in the harbour entrance. The most common southerly swell waves in the Harbour entrance have maximum significant heights of $1.2 \mathrm{~m}$ and $8.8 \mathrm{~s}$ periods, becoming smaller north through refraction. Some degree of southerly swell is thought to be impacting the Wellington shelf for more than 80 percent of the time (Carter and Lewis, 1995).

To assess the relative influence of northerly and southerly sourced waves in the study site, Matthews (1980a) plotted the relationship between wind force and wave energy. The results of this study are presented in Figure 3. 9. They show that wave energy is strongly positively correlated to wind force for southerly winds, whereas northerly winds have a negative correlation with wave energy. This illustrates the fact that in the study area, a southerly wind will produce a wave with more transport potential than a northerly wind of the same strength. 
Table 3.2: Maximum wave heights and significant wave periods generated in northerly wind conditions for Eastern Wellington Harbour (Hastie, 1989:7).

Wind Speed

\begin{tabular}{lccccc} 
Location & Fetch (km) & & 20 knot & 30 knot & 40 knot \\
Eastbourne & & & & & \\
& 6.5 & Height (m) & 0.4 & 0.75 & 1.1 \\
& & Period (s) & 2.4 & 3 & 3.5 \\
Camp Bay & 10 & Height (m) & 0.6 & 0.9 & 1.5 \\
& & Period (s) & 2.9 & 3.5 & 4 \\
Hinds Point & \multirow{2}{*}{12.5} & Height (m) & 0.7 & 1.2 & 1.8 \\
& & Period (s) & 3.1 & 3.9 & 4.5 \\
Pencarrow Head & \multirow{2}{*}{14.5} & Height (m) & 0.75 & 1.4 & 2 \\
& & Period (s) & 3.4 & 4.1 & 4.7
\end{tabular}

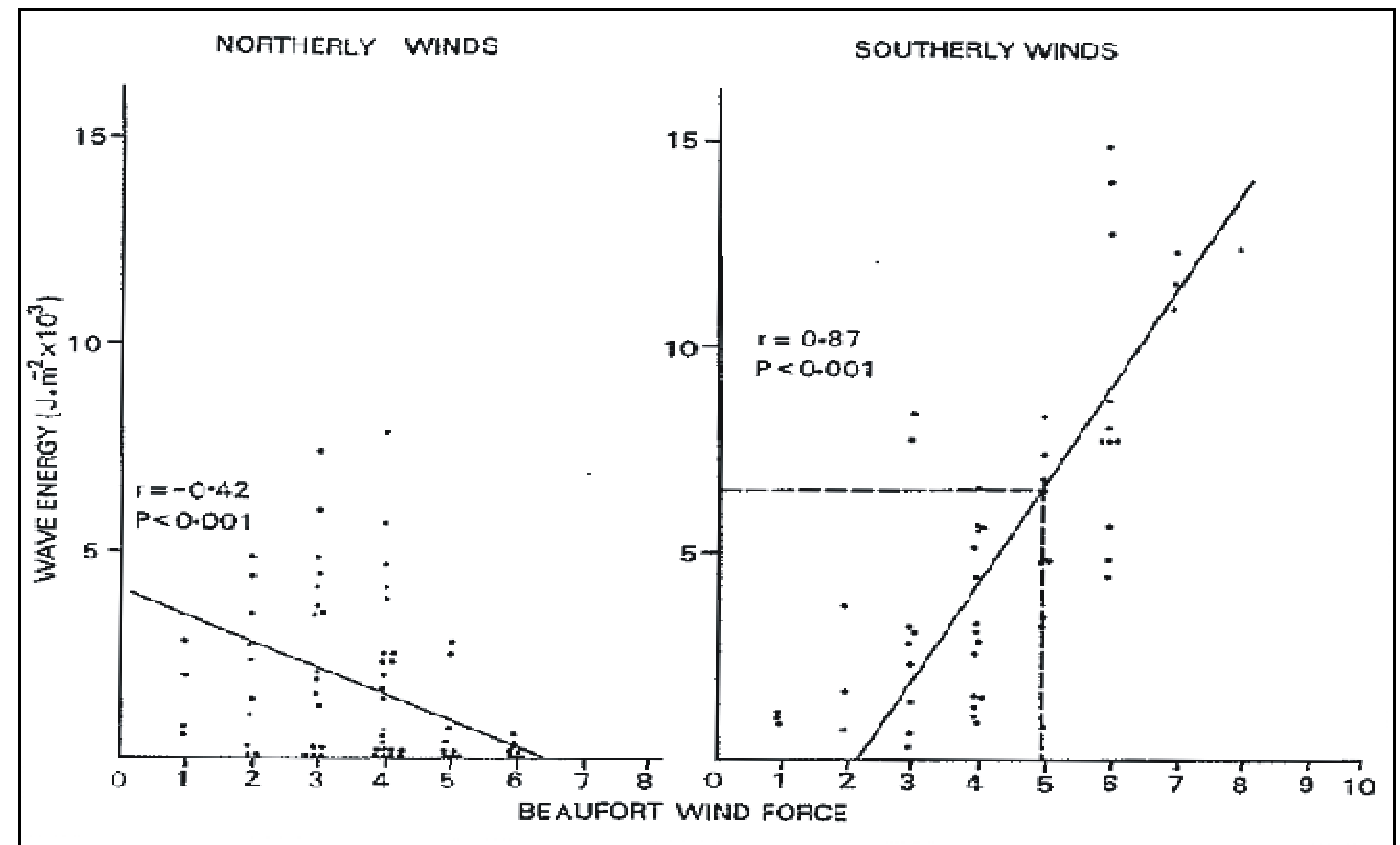

Figure 3.8: Relationship of wave energy and wind force for waves recorded at Beacon Hill on the opposite side of the Harbour entrance (Matthews, 1980a:6). There is a strong positive correlation between southerly wind strength and the energy of the waves produced. However, there is a negative relationship between northerly wind strength and energy of the waves produced.

One of the factors that influence the distribution of wave energy is the angle of approach of a wave relative to the shoreline. Figure 3.9 shows the path of a southerly sourced nine second wave as it is enters the harbour and is refracted (Hastie, 1989:9). This diagram shows that between Turakirae and Baring Heads, the wave energy is high but the 
angle of approach is small. Further north, although wave energy is decreasing through refraction and shoaling on the Eastbourne Platform, sediment transport potential remains high due to increasing wave angles relative to the coast. This means that southerly swell waves lose wave energy as they enter the harbour but maintain the ability to transport sediment northward.

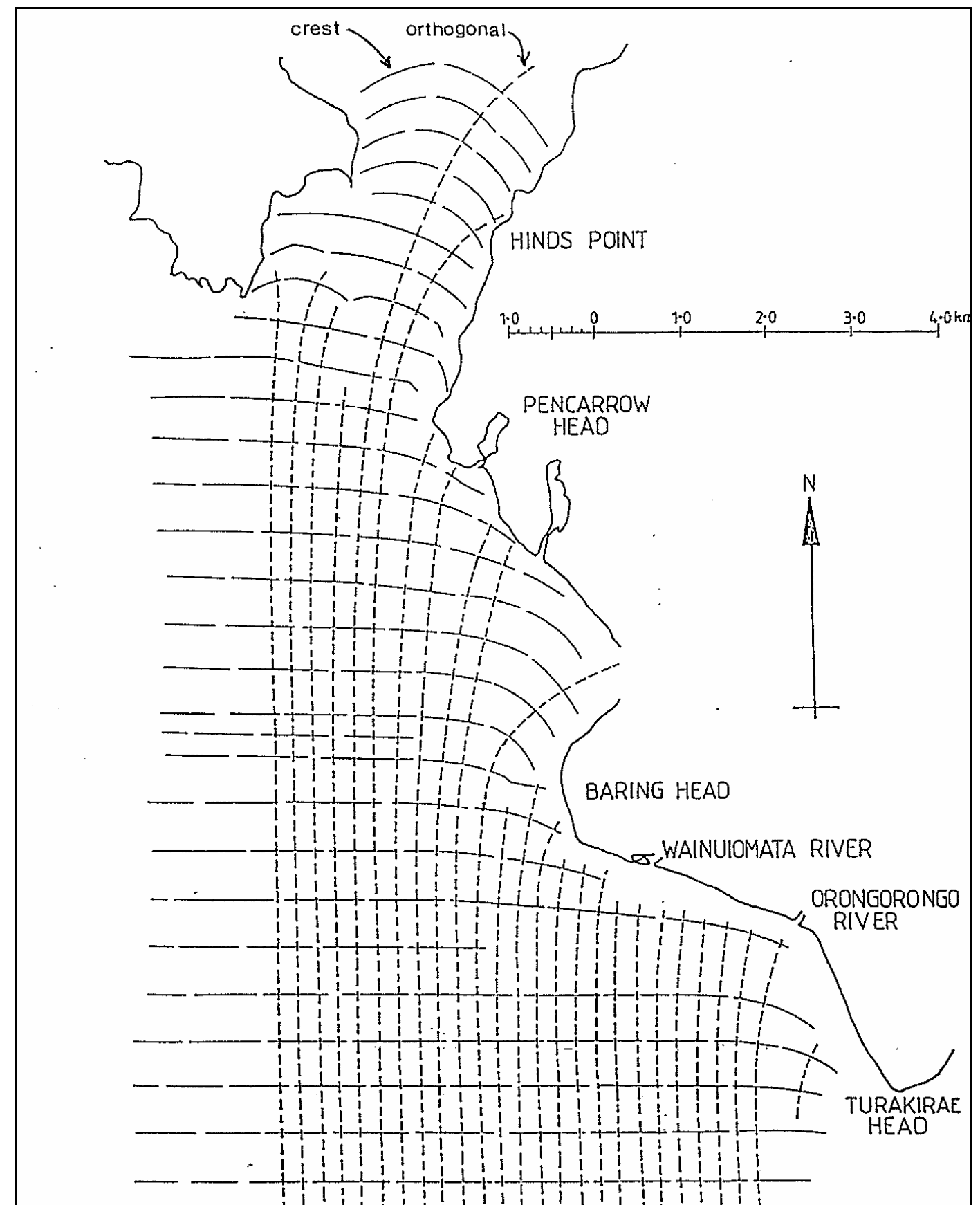

Figure 3.9: Wave refraction diagram for the south coast for a deep water wave from the south with a period of 9s (adapted from Hastie, 1989:9). 


\section{ii. Tidal Currents}

Though not the main influence on sediment transport patterns, tidal influence is still an important factor due to the study area being in an estuarine system. Cook Strait has been shown to have a powerful tidal current dominated by the M2 lunar semidiurnal tidal component, with a vertical range of $1.5 \mathrm{~m}$ (Carter and Lewis, 1995). Tidal currents at the Harbour entrance have a maximum flow speed of between 19 and 46 $\mathrm{cm} / \mathrm{s}$ which though powerful enough to move sand intertidally, is hypothesised to be too weak to instigate coarse sediment transport alone (Carter, 1977).

\subsection{Landuse history}

\section{i. Settlement and development}

Eastbourne was established first as a settlement for weekend holiday makers. As access improved it developed into a small coastal suburb with permanent residents able to commute to Wellington and Lower Hutt. Since the Second World War, better roads improved access allowing Eastbourne and the bays to develop into a substantial and affluent suburb (Beaglehole and Carew, 2001). The presence of cuspate foreland has allowed for the concentration of buildings on the flatter sections of land. Much of the residential development is situated on the former dune field, with housing foundations set in sand; however, development has also spread onto the hillslopes in most of the Eastern Bays. The 2001 population was 4,704 (Statistics NZ).

\section{ii. Coastal modification and erosion mitigation}

The coastline itself has been significantly modified over the period of European occupation, mainly through the construction of the coastal road and its associated protection initiatives. A sea wall and groyne system was established in Robinson Bay in the 1900s, but was largely ineffective in 
preventing erosion, and failed in response to two storms in 1934 and 1936 (Gibb, 2005). A more robust wall was constructed in 1956-7, combined with metal groynes for sand retention (Matthews, 1980). This wall was largely effective but concentrated erosive force north to recreation ground. As such, a boulder rip rap was built in the 1970s to protect that area (Fig. 3.10).

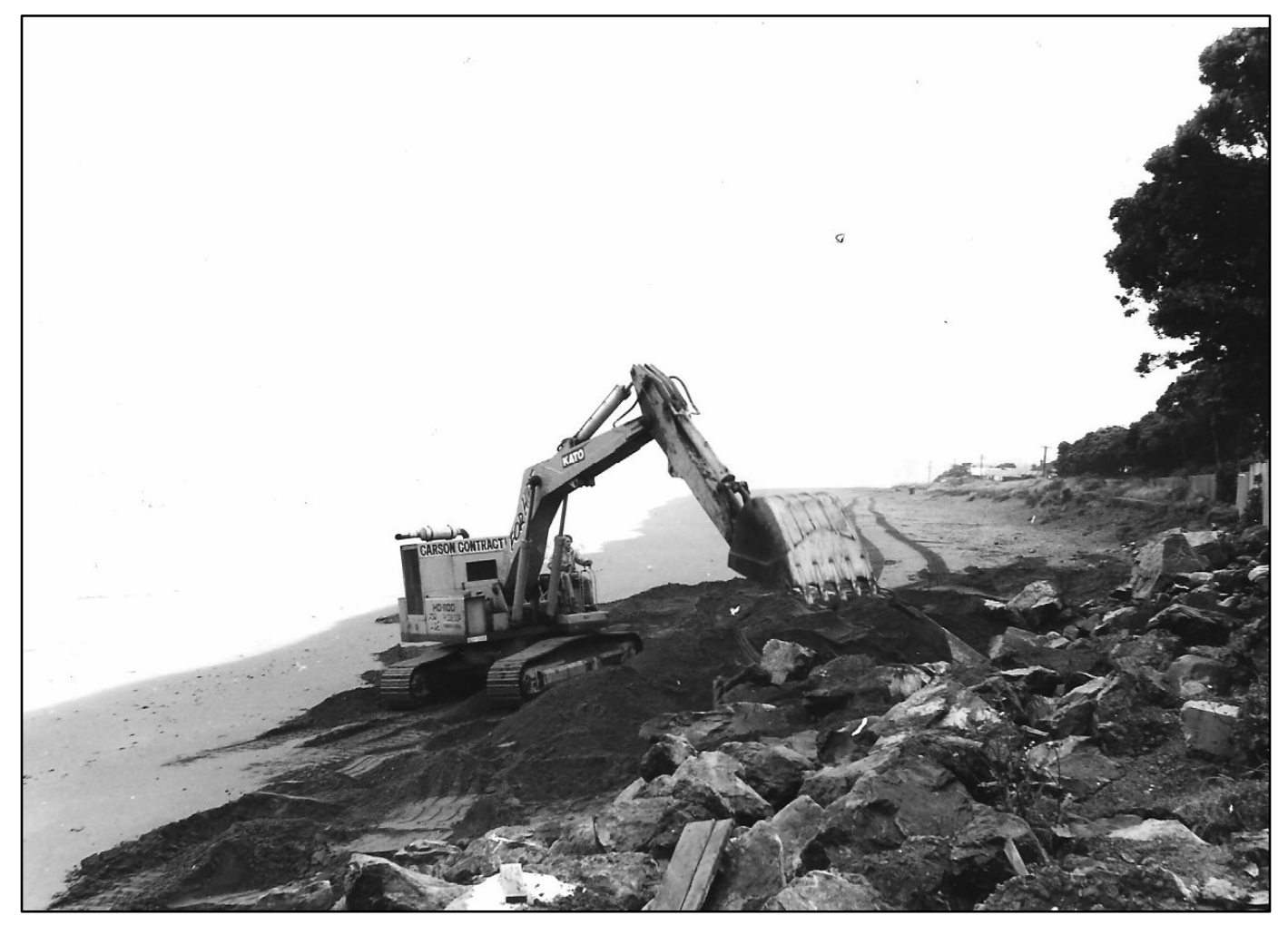

Figure 3.10: Construction of the boulder rip-rap in northern Robinson Bay in response to erosion in the 1960s and 1970s (Courtesy of the Eastbourne Historical Society).

Recently, the gravel front has rendered the sea wall redundant, and the metal groynes have been removed as a safety measure, as only the tips were protruding from the gravel, creating a hazard for walkers. 


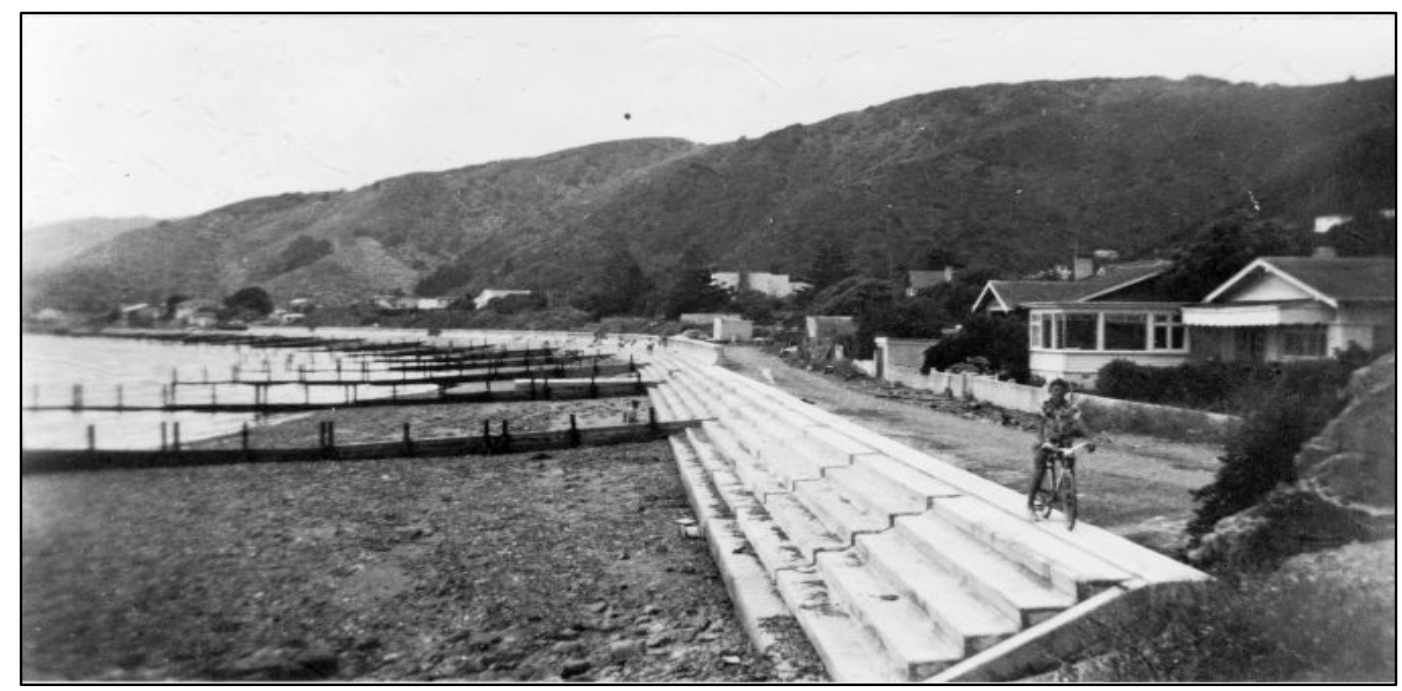

Figure 3.11: Coastline at Lion's Rock looking north during the late 1950s following completion of the current sea wall (Courtesy of the Eastbourne Historical Society).

\section{iii. Coastal aggregate extraction}

Both the Eastbourne and Pencarrow coastlines have been affected by gravel extraction since the 1920s. Gravel has been removed for industrial purposes from two sites, between Orongorongo and Wainuiomata rivers, and at Fitzroy Bay. This mining was a cause of controversy in 1970s as it was suggested that mining activities were linked to coastal erosion in Eastbourne (Hastie, 1989). An investigation into the mining operation conducted by GWRC suggested that erosion in Eastbourne is largely unrelated to the gravel extraction. However, it concedes that the gravel supply is variable, and under low supply conditions mining may contribute to localised erosion at extraction sites (Hastie, 1989). 


\section{Chapter Four: Methodology}

\subsection{Introduction}

The quantification of morphological changes in a mixed sand and gravel system requires the implementation of field and laboratory based techniques. The main aim of this chapter is to summarise the techniques used in this research project, and to discuss the theoretical frameworks on which they are based. Topographic surveying has been utilised to measure the detailed spatial variation in beach morphology, while short term temporal dynamics in the order of weeks/months were quantified through repeat measurement of specific profiles. Aerial mapping was used to show wider scale temporal shoreline movement. These data are combined with sedimentological analysis to show the relationships between grain size and morphology in the eastern coast of Wellington Harbour.

\subsection{Topographic surveying}

Topographic surveying is an accurate method of measuring shoreline changes both spatially and temporally (e.g. Cooper et al., 2000; Huang et al., 2002), and has been implemented to show spatial and seasonal variation in gravel beaches (e.g. Caldwell and Williams, 1986). For the present study beach profiles have been surveyed to: (1) show variation in beach width and shape through Days, Robinson and Rona Bays, and (2) calculate approximate volumes and changes in cross-sectional area in response to the mobile gravel front migrating north along the Eastbourne shore.

\subsubsection{Survey method}

Sixty-two transects were surveyed from an approximately $5 \mathrm{~km}$ long stretch of coastline between Days Bay and Burdans Gate (Fig. 4.4), Surveying was conducted over several days throughout 2008 and 2009 using a Sokkia 3030R Electronic Distance Meter (EDM). An EDM measures points 
in 3-dimensional space with a complex angle measuring component and the emission and reflection of a laser between base station and target point. This information is used to calculate the position of a target using its azimuth from a basic direction and the measured distance between the target and the point of measurement (Huang et al., 2002). The 3030 model used in this study can measure up to 5000 m with an accuracy of \pm $(2+2 p p m \times D) \mathrm{mm}$.

Suitable base station sites were selected to incorporate the maximum range of vision, and profiles were surveyed at spacings of 20 to $50 \mathrm{~m}$. Profiles extended seaward from the backbeach area, often dictated by the presence of the road or other anthropogenic structures, to the submerged breakpoint step in the nearshore zone. Surveying was conducted as closely to low tide as possible. Selected profiles in Robinson Bay were repeat surveyed on 11 February 2009 and 5 August 2009 to document the short term morphological changes and seasonal variation through the key study areas.

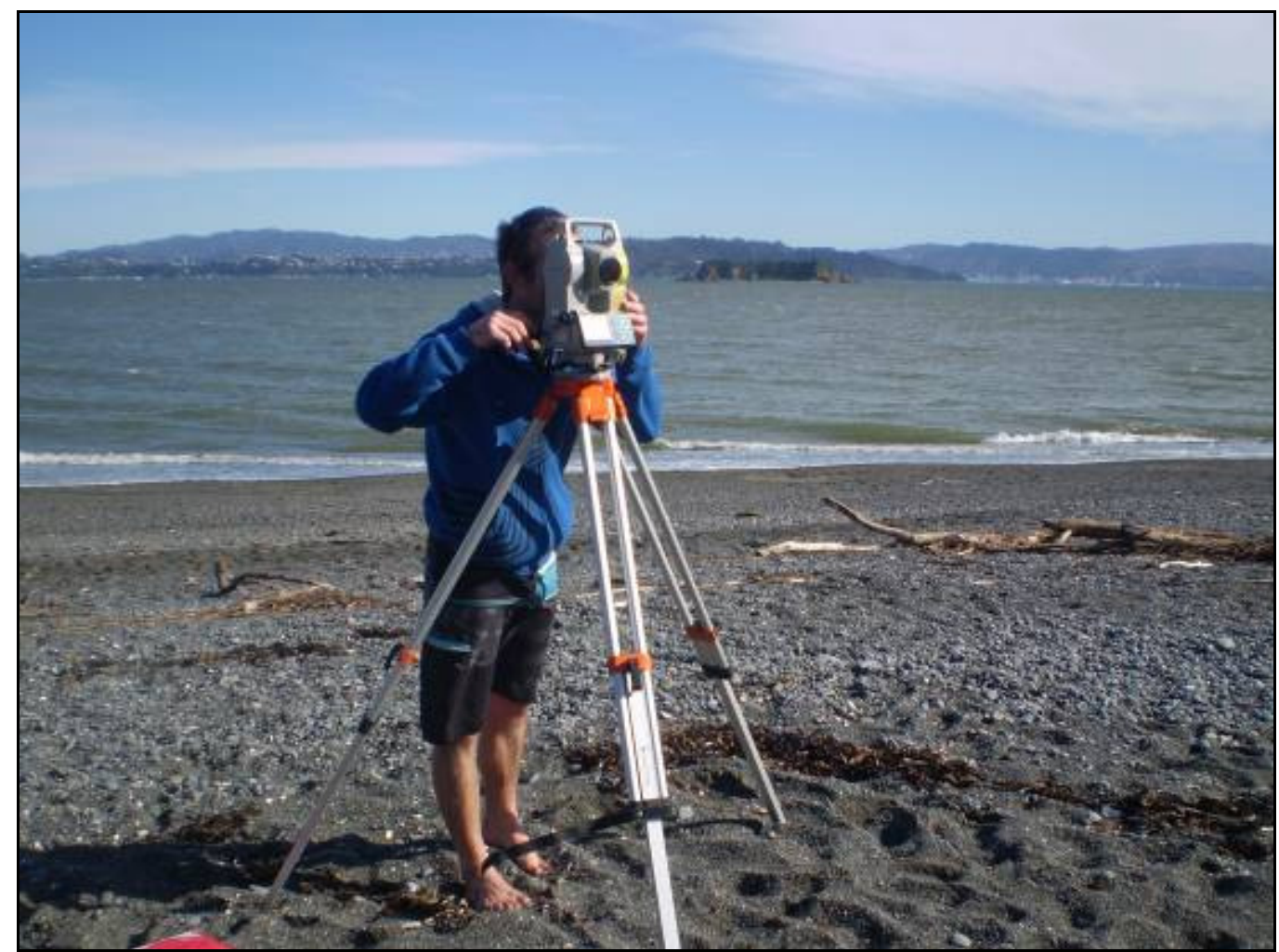

Figure 4.1: EDM surveying at Robinson Bay. Figure shows Ward Island and Wellingtons Miramar Peninsula in the background. 
Mapsuite+ v6.1 software was used to convert recorded EDM points into profiles which were then plotted in Microsoft Excel. Profiles were reduced in Mapsuite to mean sea level height, based on LINZ geodetic survey marks SS V SO 15726 (SO 36385) and RM 2 SO 36385 (LINZ, 2007). Profiles drawn in Excel were used to calculate mean slope and mean foreshore slope as in Jennings and Shulmeister (2002). The foreshore slope was defined as extending from the top of the highest berm to the most seaward point surveyed. Key features such as berms or dunes were documented to assess their longshore position variability.

\subsubsection{Area and volume calculations}

The area under the sub-aerial component of each profile was calculated to observe the spatial differences in area and volume through out the study site, and to approximate a sediment budget for Rona and Robinson Bays. In order to do this, the areas of all the component parts of each profile were calculated and combined to give total cross sectional area for each profile. Areas of all of the profile components, as indicated by dashed lines in Figure 4.2, were calculated by multiplying the width of each section by the average height of $\mathrm{H} 1$ and $\mathrm{H} 2$ (Fig. 4.2). These were combined to give total cross-sectional area for each profile. To then calculate volumes between adjacent profiles, the average area of the two cross sections (transects 1 and 2, Fig. 4.4), was multiplied by the horizontal distance between profiles taken from Mapsuite+ survey drawings. 


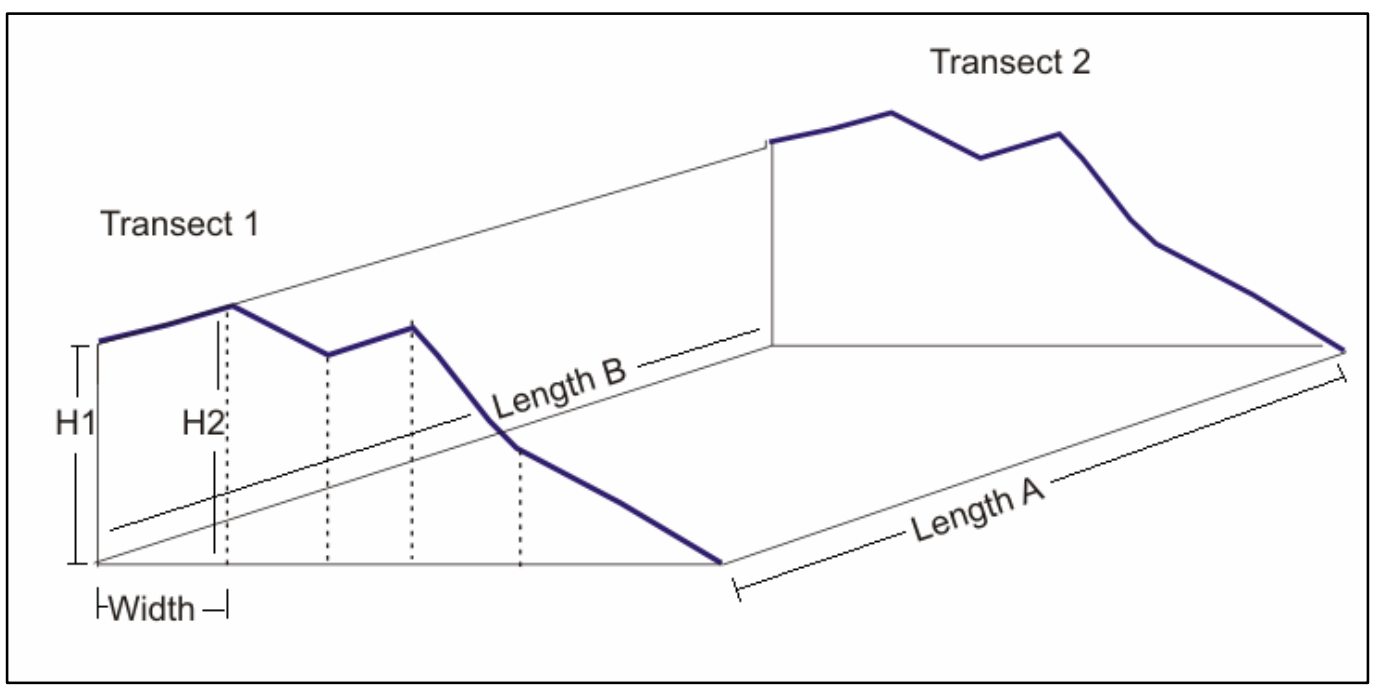

Figure 4.2: Schematic diagram of technique used to calculate cross sectional area and volume of the section between profiles.

\subsection{GIS Mapping}

Aerial photograph analysis was utilised to show decadal scale shoreline evolution along the Eastbourne coastline. Aerial photos from 1941, 1954, 1969, 1975, 1985, 2001 and 2008 were sourced from NZ Aerial Mapping Ltd and Greater Wellington Regional Council. Of the hardcopy photographs supplied, scales ranged from 1:3000 for the 1975 photos to 1:17000 for the 1941-1969 photos (with enlargements of Rona and Robinson Bay at 1:4500) and 1:20000 for the 1985 photographs.

Aerial photograph analysis is subject to error from a number of sources that may significantly affect the accuracy of related calculations (Gibb, 1978). Amongst these sources of error include: (1) the process of capturing aerial photos, which introduces scale inconsistencies from variations in height and angle of plane approach (Leatherman, 1983). (2) The provision of tide data for photo sets, as some of the pre-digitised photographs do not have time information supplied. (3) Differing photo quality and digital resolution and, (4) the simple fact that aerial photographs are momentary records of antecedent conditions and as such may not be truly representative of the longer term changes as apparent changes may be temporary and detract from overall trends (Smith and Zarillo, 1990). 
These possible sources of error should be considered in the interpretation of any patterns of movement apparent in the beach measurements through time, but more salient results still account for the error and may be used to calculate real as opposed to apparent shoreline alteration.

\subsubsection{Georeferencing}

Geographic Information System (GIS) software (ArcGIS version 9.3) was used to map and measure shoreline changes observed in the historic and contemporary aerial photos. The photos were digitised and georeferenced to the already referenced regional council photo dataset.

All hard copy photographs were scanned at photographic (minimum resolution 600dpi). Selected photos were up to $1200 \mathrm{dpi}$ based on quality and scale. They were saved as JPEG files and imported into ArcGIS. Photographs imported into the GIS map grid were registered using the New Zealand Map Grid projection coordinate system to project them accurately onto the map grid. The 2008 series of high-resolution photos were used as base references as they are representative of current conditions and were supplied already georeferenced. The historic photos were imported into ArcGIS and the georeferencing tools were used to link common points for the other photograph sets to be rubber-sheeted. A minimum of seven comparable points were used for rubber-sheeting each historic photo to the georeferenced 2008 image. These points were selected to be permanent features where possible (for example corners of identifiable buildings). Points were distributed to span the area covered by the photographs. Residual error related to inconsistencies of stretching photos to fit the grid was quantified and kept to $< \pm 4 \mathrm{~m}$ horizontally where possible, with a maximum horizontal error of $7 \mathrm{~m}$ for one of the 1975 photos of the Pencarrow Coastline, where permanent features were harder to identify and warping was less accurate as a result. This $< \pm 4 \mathrm{~m}$ of horizontal error, although significant to the accuracy of shoreline measurement, is accounted for in the more obvious beach width changes 
as it is of a lower magnitude than the observed change and is therefore deemed negligible.

\subsubsection{Digitising features and the calculation of historical shoreline movement}

The locations of the surveyed transects as recorded by GPS during fieldwork were inputted into Arcmap and profiles were drawn on the basis of these points. These profiles were saved as features and numbered in GIS to identify them throughout the measurement process.

The Arcmap editor tool was used to create separate polygon features for each shoreline by carefully tracing the beach planform for each georectified photoset (Fig. 4.3). The beachface measured in these analyses was defined as extending seaward from vegetation lines or road edges to the gravel/sand boundary in the nearshore zone. Certain photo sets were lower resolution and the nearshore morphology was difficult to identify. These were the 1969 and 2001 photographs, where the toe of the beach was traced as the breaker line, as the gravel boundary was largely unidentifiable. This created an additional source of horizontal error of approximately $\pm 5 \mathrm{~m}$. The ArcGIS measure tool was then used to measure the length of each profile between the outlines of the shoreline features (Fig. 4.3). This process was repeated for all profiles for each historic shoreline feature. These widths were imported into Excel and used to show overall beach widths for each dataset, and to calculate the changes in width between the photosets. The annual rates of change were calculated for each profile by dividing shoreline movement by time in years, and the ArcGIS software was used to automatically calculate polygon area for each shoreline polygon for temporal comparisons. 


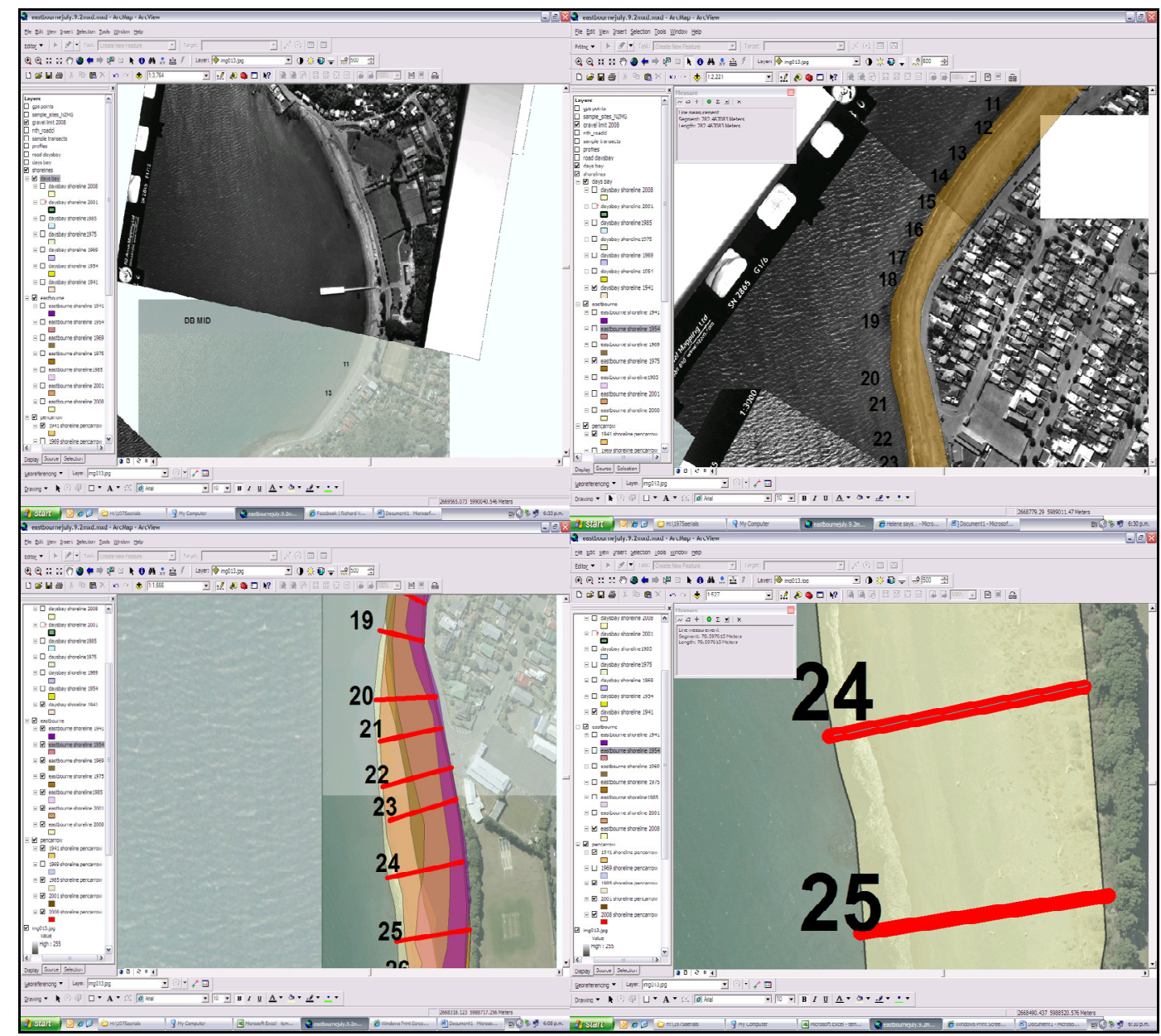

Figure 4.3: Aerial mapping procedure in ArcGIS. Clockwise from top left: rectifying historic photos, digitising shoreline features, overlaying profiles and different shorelines, measuring profile width for each shoreline feature.

\subsection{Sediment Analysis}

Early studies have established (e.g. Inman, 1952; Folk and Ward 1957) that sediment size is a vital factor in the mechanics of clast transport. The Krumbein (1934) phi scale has been observed in classifying the clast size ranges in this study. This scale is based on the Udden-Wentworth system of universal size grading where size grades are separated by factors of two based on a grain size centre of $1.0 \mathrm{~mm}$. The statistical analysis of a grain size distribution allows for the calculation of parameters that can be compared across samples (Leeder, 1982). The standard statistical parameters, as seen in Folk and Ward (1957), have been employed here to describe variation within the depositional environment of the Eastbourne coast. As the Eastbourne coastal sediments comprise a broad 
range of grain sizes and types, three methods of size analysis have been implemented in this study: direct calliper, dry sieving, and laser diffraction.

\subsubsection{Surface sediment collection}

Seventy-seven sediment samples were taken from Eastbourne and Days Bay for grain size analysis. The samples were collected from 12 selected transects previously surveyed (Fig. 4.4). Three to six samples were collected from each transect, from the backbeach area (and dunes if present), from each berm, through to the low tide terrace, and from the swash zone at the low tide waters edge. Sample location was recorded using a Garmin handheld GPS unit. Approximately 1-2kg samples were taken from the surface of the beachface using a spade and sealed in plastic. Where sample locations were particularly coarse ( 95\% coarser than $16 \mathrm{~mm}$ ) and fines visually absent, clasts were point counted using the calliper method described below. 


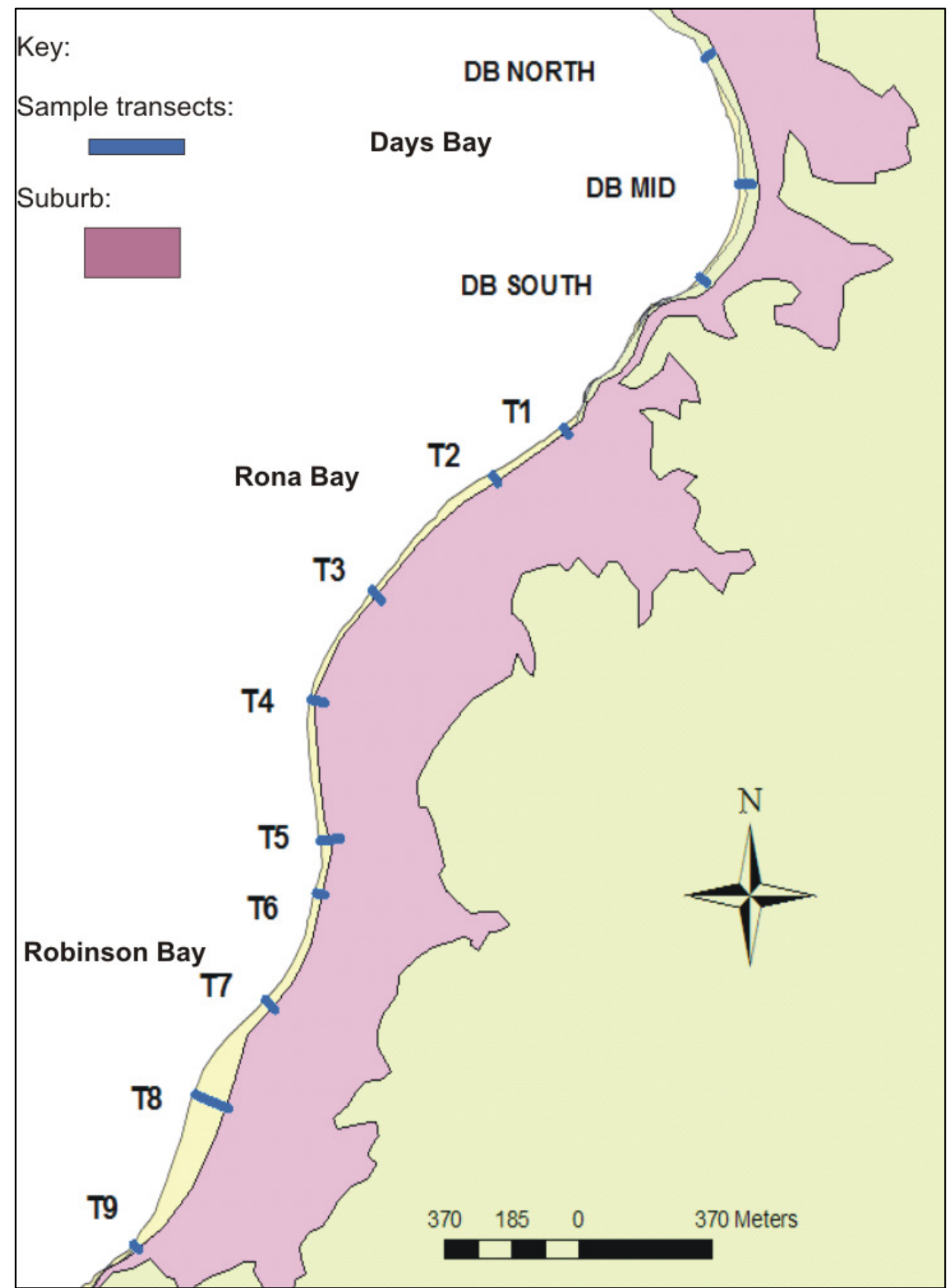

Figure 4.4: Map of Sediment sample transects from Days Bay, Rona Bay and Robinson Bay. 


\subsubsection{Caliper Measurements}

Direct Caliper measurements were applied to samples dominated by gravels too coarse for accurate sieving $(>-4 \Phi)$. This is partly due to the obvious difficulty in transporting representative populations of coarse gravel, and partly due the limited availability and accuracy of sieve meshes coarser than $-4.5 \Phi$. Following the procedure adopted by Jennings and Shulmeister (2002), a $90 \mathrm{~cm}^{2}$ quadrant was placed on the beach surface at these coarser sites. The 30 largest grains within the quadrant area were visually selected and their $B$ axes were measured.

\subsubsection{Dry sieving}

Dry sieving has been used for the majority (86\%) of the samples because it is a universally applied and easily reproducible technique for grain size analysis (Gale and Hoare, 1991). It can also account for the fine sand to coarse gravel fractions in a single analysis. Dry sieving works on the principle that grain size is determined by the smallest sieve diameters that catches the $b$ - or intermediate axis. From this, they are then equated to spheres of equal diameter (Le Roux, 1998). As some grains may actually be elongate or platy in shape, the assumption of spherical equivalence introduces systematic error to the sieving process (McLaren, 1981), as sieve stacks sort particles by shape as well as size (Komar and Cui, 1984). Although the effects of particle shape on hydraulic behaviour are not accounted for in sieving (Gale and Hoare, 1991), this method offers a best approximation of depositional energy processes operating in the eastern bays.

All samples were washed and dried at $100^{\circ} \mathrm{C}$ for approximately 72 hours prior to sieving. Samples were sieved at half phi intervals from $-4 \Phi$ to $0.5 \Phi$ with any finer fraction collected in the pan for further analysis. Samples were poured into the sieve stack and shaken for a total of 15 minutes at a medium intensity level using a Fritsch analytical sieve shaker 
(Fig. 4.5.). This shaking cycle alternated between interval and microinterval modes. The contents of each sieve were weighed to $0.01 \mathrm{~g}$.

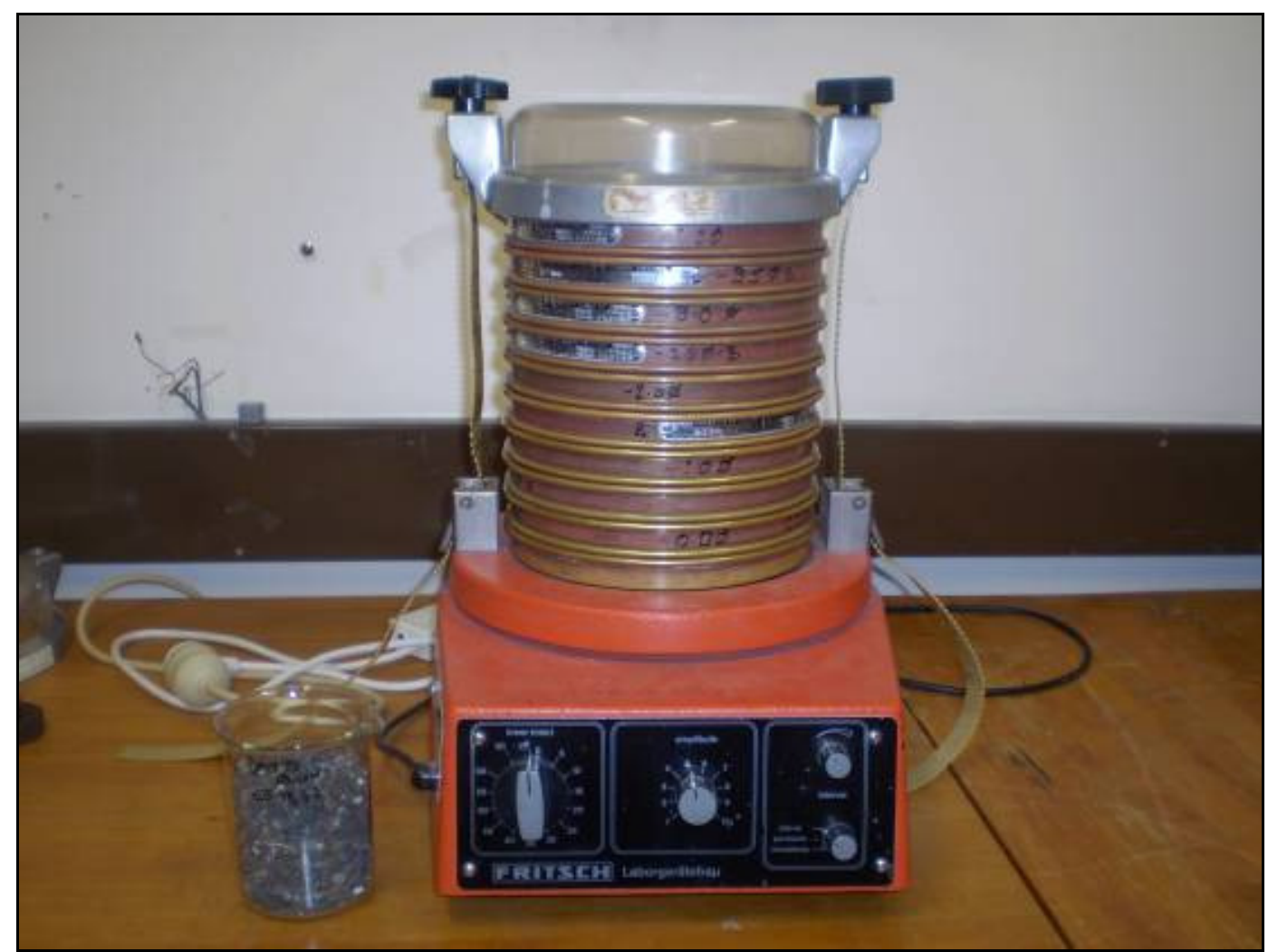

Figure 4.5: Dry sieve stack and Fritsch mechanical shaker.

Once the raw data had been collected, statistical parameters were calculated to determine patterns in these data. Grain size frequency histograms were plotted for each sample, and cumulative frequency graphs were plotted in Excel to allow for the calculation of sediment size characteristics using the graphical method of Folk and Ward (1957). This method has been compared with the method of moments technique introduced by Van Orstrand (1925) and has been found to be an accurate method of parameter calculation for mixed sand and gravel systems (Dawe, 1997).

This technique of parameter calculation involves the construction of a grain size distribution curve, most commonly a logarithmic cumulative curve plotting cumulative weight ( $y$ axis) against grain size in phi ( $x$ axis). Quantitative readings are taken directly from the curve and entered into the equations given by Folk and Ward (1957). The characteristics 
determined for each sample were median and mean grain size $(\Phi)$, sorting (standard deviation), and skewness, calculated from the cumulative frequency graphs using the following:

Median $=\mathrm{D} 50\left(50^{\text {th }}\right.$ percentile where $\left.\mathrm{y}=50\right)$ read directly from the cumulative frequency graph

Mean $=\frac{\Phi 16+\Phi 50+\Phi 84}{3}$

Standard deviation (sorting) $=\frac{\Phi 84-\Phi 16}{4}+\frac{\Phi 95-\Phi 5}{6.6}$

Skewness $=\frac{\Phi 16+\Phi 84-2 \Phi 50}{2(\Phi 84-\Phi 16)}+\frac{\Phi 5+\Phi 95-2 \Phi 50}{2(\Phi 95-\Phi 5)}$

\subsubsection{Laser Diffraction Analysis}

The grain size fraction $<-0.5 \Phi(1.41 \mathrm{~mm})$ was analyzed using a Beckman Coulter multi wavelength LS13320 Laser Particle Sizer (LPS) (Fig. 4.6). Laser diffraction specifications included use of an optical model appropriate for quartz spheres, assuming: refractive index of water $=1.33$; real refractive index of sample $=1.55$; and imaginary (absorptive) refractive index of sample $=0.0$. Software was Beckman Coulter LS13320 version 5.01. This method was chosen as it is a time-efficient and reproducible method of measuring sand to clay-sized sediment samples. 


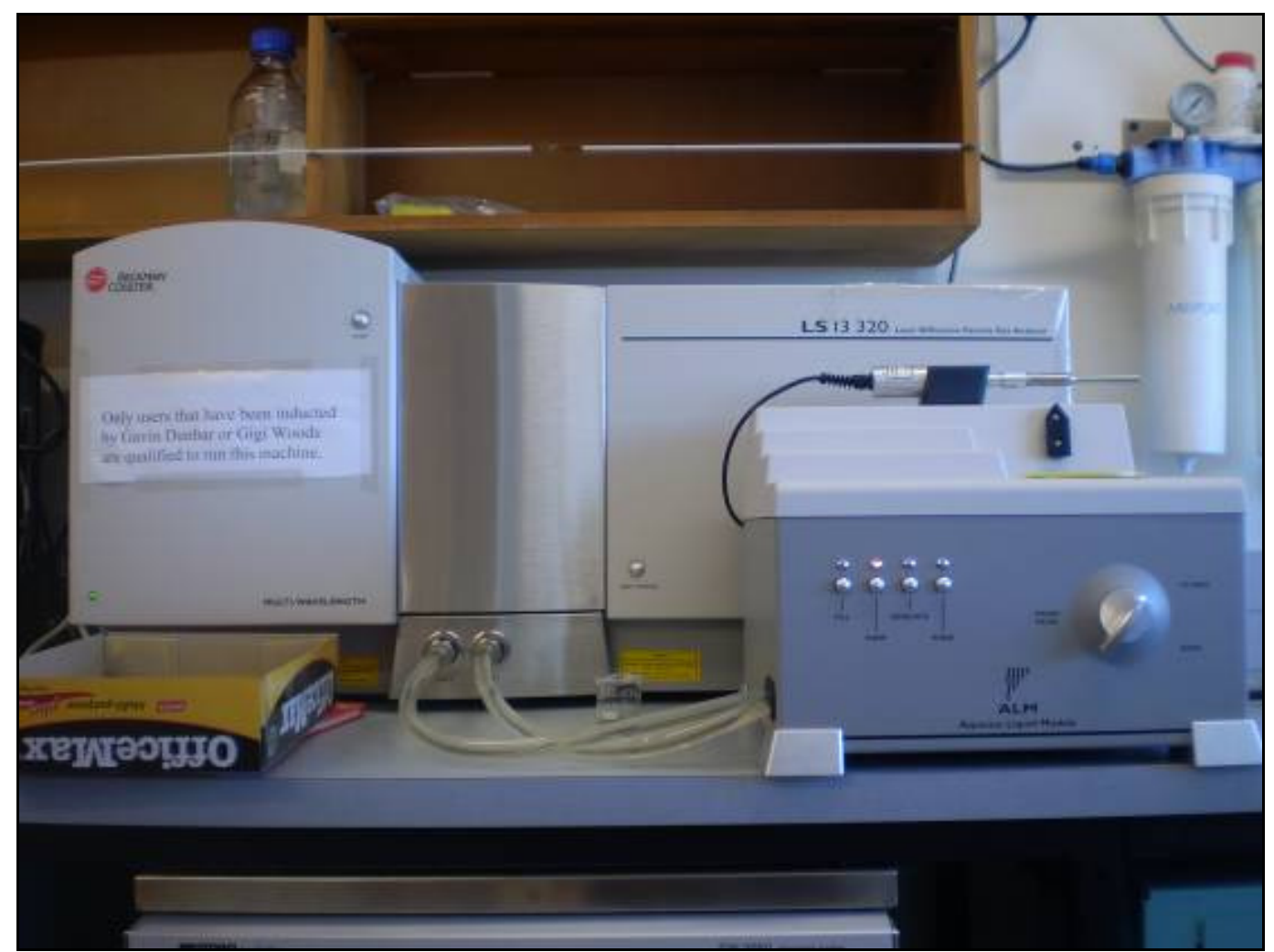

Figure 4.6: LS13 320 Laser particle sizer, showing the processing unit to the left and the sampler on the front right.

Laser diffraction grain size analysis is based on the interaction between light and particles (Loizeau et al., 1994). The underlying principle is that particles diffract light at a specific angle, which increases with decreasing particle size (McCave et al., 1986). In this analysis, a 13mm diameter laser beam created from the expansion of monochromatic light is passed through a suspended sediment sample. The light is scattered onto two Fourier lenses, which focus it onto detectors (Fig. 4.7). The lenses direct light of the same diffraction angle onto the same detector creating a light diffraction pattern, which is then converted to a particle size distribution using an inversion logarithm based on Fraunhofer and Mie diffraction theories (Loizeau et al., 1994).

Diffractometry measures the cross-sectional diameter of particles according to the angle of the diffracted light, rather than as a function of intermediate axis length, as in dry sieving (Rodriguez and Uriarte, 2009). Furthermore, the grain size distribution is calculated in terms of volume percentage, rather than weight percentage as in sieving. Diffraction 
analysis has been compared with dry sieving in several studies (e.g. Rodriguez et al., 2009; Beuselinck et al., 1998) and it has been found the two techniques are not as directly comparable when complicating factors such as complex grain size come into play.

Sieving and laser diffraction measure slightly different aspects of grain diameter. Whilst sieving provides mass \% of particles with diameters equivalent to those of perfect spheres, laser diffraction measures volume $\%$ of average cross-sectional diameters that pass through the laser (optical diameter). These two parameters are least comparable when sediment shape and density are highly variable in the fines fraction (Beuselinck et al., 1998). For example, elongate or platy particles may have a larger average optical diameter than sieve diameter, thereby skewing the overall grain size distribution to the coarse end in LSD results. Consistency in shape and lithology play a necessary role in the generation of consistent grain size results.

To account for this, using the comparative chart of Russel, Taylor and Pettijohn (Muller, 1967), the sediment fraction finer than -0.5 phi $(1.41 \mathrm{~mm})$ was examined under binocular microscope to assess qualitative shape characteristics (Fig. 4.8). Approximately 95\% of the material is comprised of subrounded to well-rounded quartzofeldspathic clasts (dominantly greywacke). Approximately 3 to $5 \%$ is contributed by platy-shaped shell fragments. This suggests that complicating factors such as highly irregularly shaped grains and density contrasts from variable mineralogy are not significant in the eastern Wellington Harbour system, and the grain size distributions from sieving and laser diffraction techniques can be assumed to be reasonably comparable. 


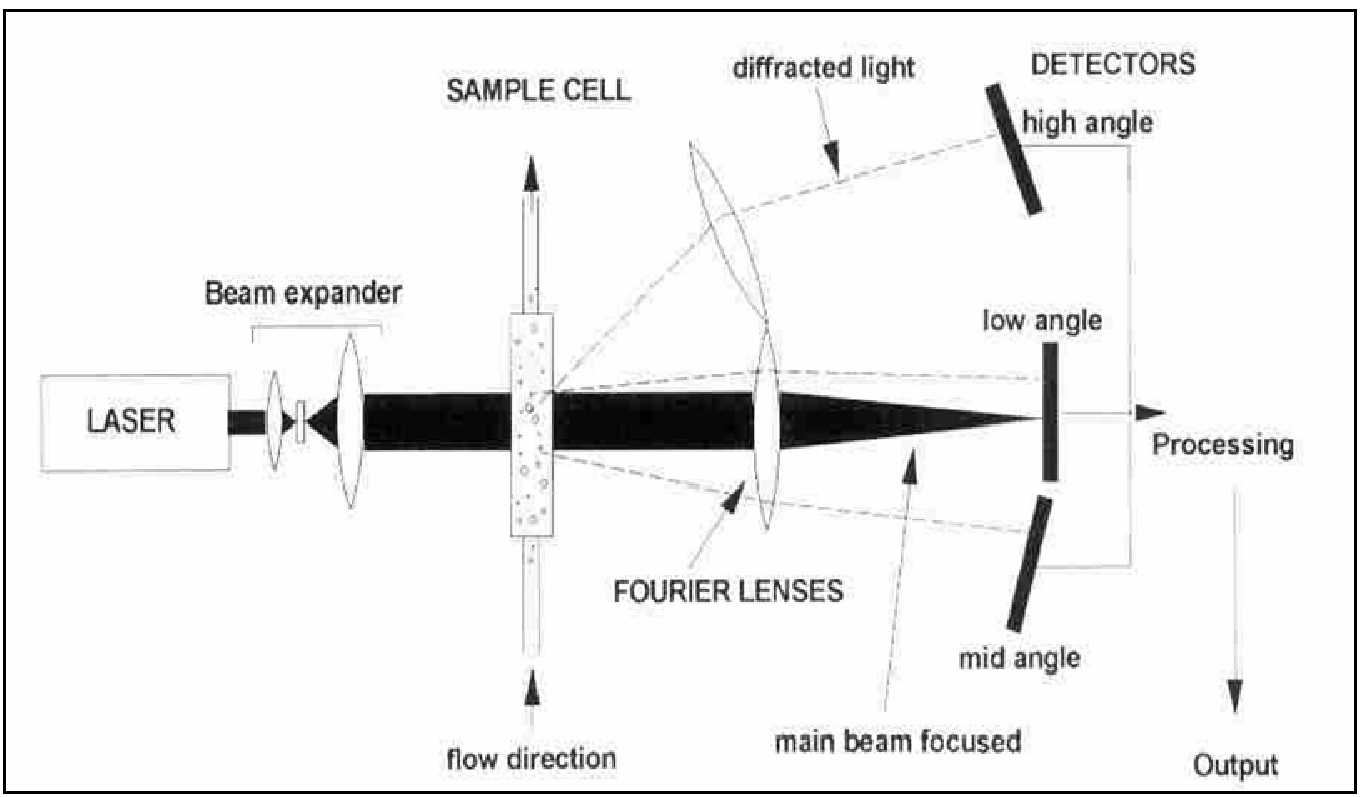

Figure 4.7: Schematic diagram of the Beckman Coulter particle sizer (from Loizeau et al., 1994: 354). A laser is directed through a suspended sediment sample and focussed by fourier lenses onto detectors, then processed to calculate grain size distribution of the sediment sample.

For dune and low tide sand samples, sediment was poured through a $0.5 \Phi$ sieve to remove any coarser material. The other samples from the mixed sand and gravel sites were already sieved to $-0.5 \Phi$ and were collected from the pan to be sampled if there was sufficient material. A total of 20 samples were run through the LPS at 8 to $12 \%$ obscuration for 60 s per sample. The LS 13320 software was used to calculate differential and cumulative volume percentages for half-phi size intervals. The LPS analysis calculated the statistical parameters automatically.
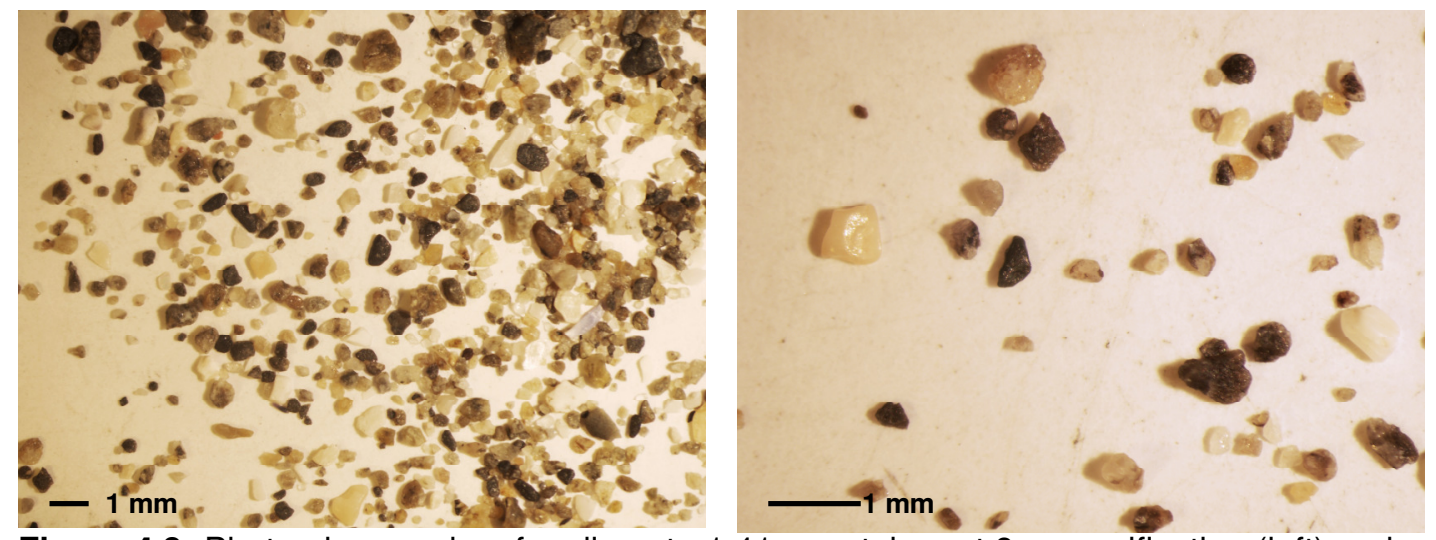

Figure 4.8: Photomicrographs of sediment $<1.41 \mathrm{~mm}$, taken at $8 \mathrm{x}$ magnification (left) and $18 x$ (right) show consistently subrounded to well rounded quartz-rich clasts and minor platy shell fragments. 


\section{Chapter Five: Results}

\subsection{Introduction}

Gravel and mixed beach research frequently involves the interpretation of the spatial and temporal characteristics of beach morphology and sedimentation (e.g. Kirk, 1980; McLean and Kirk, 1969; Jennings and Shulmeister, 2002). For this study, profile width and beach morphology are presented. Slope and elevation data calculated from the surveyed transects and have been combined with GIS historic shoreline analysis and grain size analysis to demonstrate long and cross shore variation of the Eastbourne shoreline between Days Bay and Kohingapiriri Bay. For convenience, and to allow for comparative analysis along the coastline, the study site has been divided into Days Bay, Rona Bay, Robinson Bay, Burdans Gate and Pencarrow (Fig. 3.2 and 3.3, Chapter 3).The present chapter comprises three main sections: beach morphology, temporal change and sedimentology.

\subsection{Beach Morphology}

\subsubsection{Overview}

Days Bay represents the northern most end of a littoral drift system that extends from the Orongorongo River on the Wellington south coast. Southward between Days Bay and Burdans Gate, the transition from sandy estuarine beach morphology into MSG beach morphology is observed. This regime change from sandy to mixed sand and gravel is apparent in a number of morphological aspects with distance south through the littoral drift system, including beach width, slope angle and berm number, reflecting the change in sediment size as gravel migrates northward. The complexities of these morphological trends will be addressed here, beginning with beach width.

\subsubsection{Longshore variation in beach width}


As is commonly observed in headland dominated beaches, subaerial beach width is greatest in embayments and decreases on the tip of headlands. In this system, the greatest widths are observed in embayments orientated to the northwest or southwest, relative to those facing west. A more detailed description of beach width from topographic surveying will now be given beginning with the data from Days Bay and moving south. Days Bay beach (Fig. 5.1a) is relatively narrow with subaerial widths ranging from $11 \mathrm{~m}$ at the northern headland, increasing to $29 \mathrm{~m}$ mid-bay south of the Days Bay Wharf, and reducing to $16 \mathrm{~m}$ at the southern end (Fig 5.1a, Profiles 13-14). This is presented graphically in Figure 5.2a, which shows that Days Bay Wharf appears to be acting as a groyne reducing beach width on the lee side (relative to the dominant south to north drift direction) to $10-15 \mathrm{~m}$. There is a narrow pocket beach separated by greywacke outcrops between Days Bay and Windy Point in Rona Bay. Rona Bay itself quickly widens south of Windy Point from 8 to $36 \mathrm{~m}$ at the Eastbourne Wharf (Fig 5.1b, Profiles 1-7). South of the wharf, width is relatively consistent, fluctuating between $34-45 \mathrm{~m}$ (Fig. 5.2b). This width is maintained round the outer bend between Rona and Robinson Bays, before increasing into the northern end of Robinson Bay (shown as Profile 19, Fig. 5.1). 


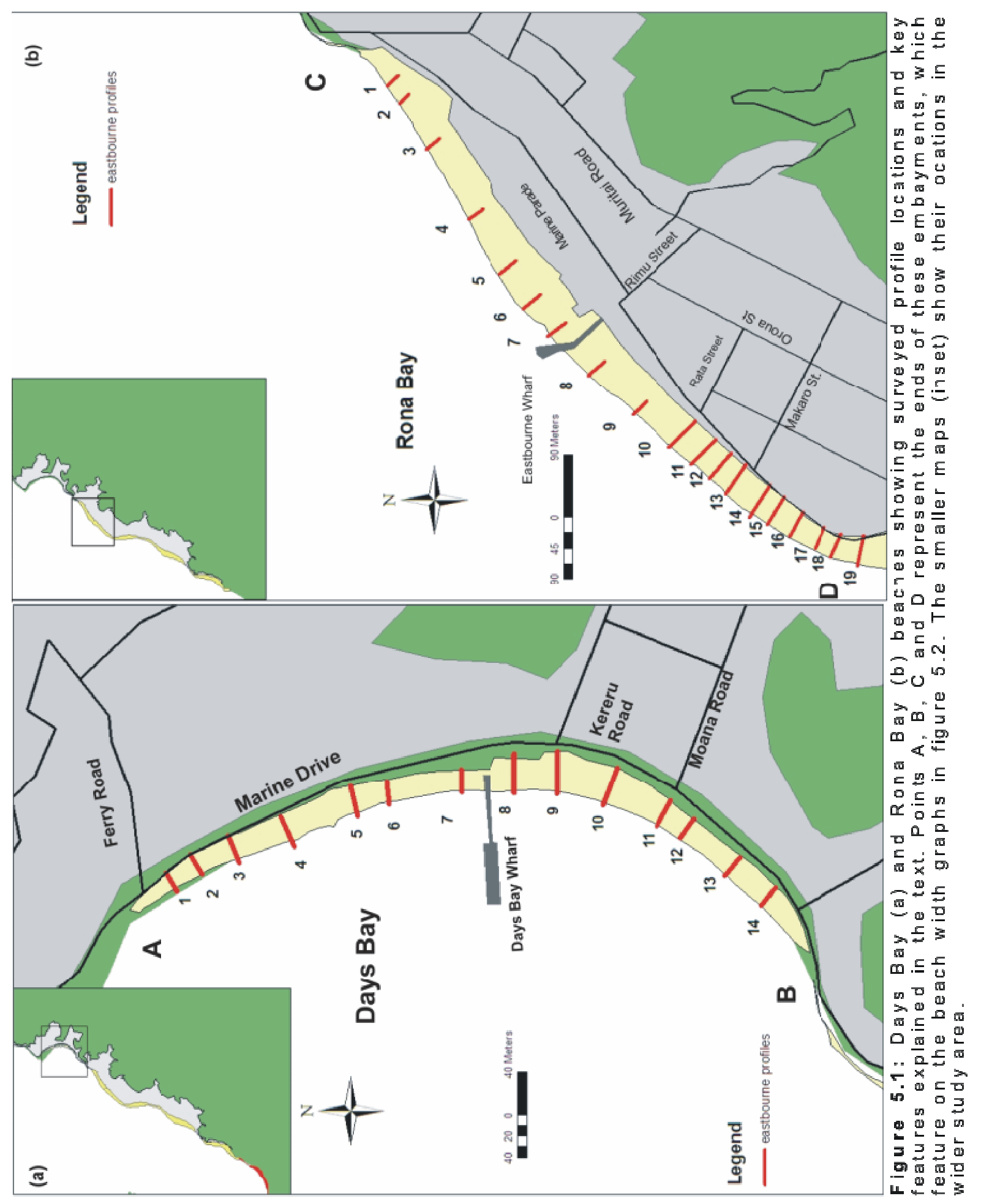



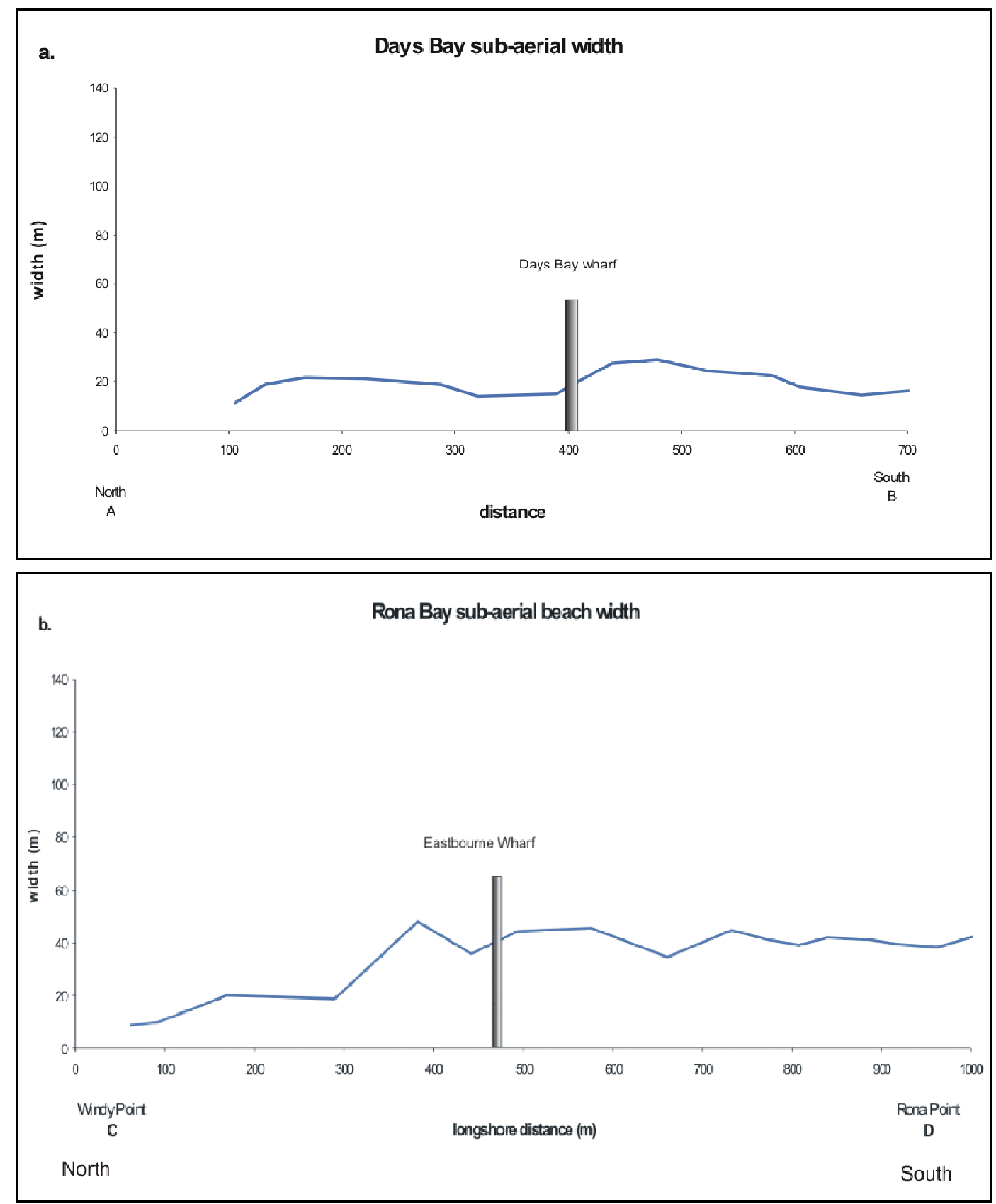

Figure 5.2: Subaerial beach width (a) Days Bay and (b) Rona Bay. A, B, C, D refer to locations in figure 5.1. Beach width for these two embayments is shown to be $10-50 \mathrm{~m}$ with minor spatial differences observed close to headlands (points A and B in Days Bay and Windy Point in Rona), where the beach narrows, as would be expected in a headland dominated beach system.

Beach width is much more variable in Robinson Bay (Fig. 5.4), where two distinct prograding sections are present. The first, located between Tuatoru Street and the parking ground at the southern end of the H.W. Shortt Recreation Grounds (Fig. 5.3a, Profiles 20-29) is 300m long. In this section, beach width is $85 \mathrm{~m}$ at its widest point, before narrowing again to $\sim 20 \mathrm{~m}$ at the northern end of the sea wall (Fig. 5.5). This section of the 
shoreline presents a weakly crescentic planform, creating accommodation space and allowing for the accumulation of sediment in this area. The narrow section at the northern end of the sea wall (Profiles 30-35, Fig. 5.3a) extends for $400 \mathrm{~m}$ before width rapidly increases into the second, larger prograding section. This larger accretionary segment has built out between Miro and Nikau Streets in southern Robinson Bay (Fig. 5.3b, Profiles 35-41). Subaerial beach width peaks at $126 \mathrm{~m}$, before quickly narrowing again to $\sim 20 \mathrm{~m}$ North of Lion's Rock, Point Arthur (Fig. 5.4). This larger prograding section occurs along a relatively linear stretch of the coast, which is drift-aligned, and resembles a smaller, developing cuspate foreland. This progradation has the effect of dividing Robinson Bay into two distinct embayments, as seen in Figure 5.4. The beach remains narrow around the headland at Point Arthur before widening slightly to between 30 and $50 \mathrm{~m}$ in the next bay south, across from the bus terminal, and later narrows to $\sim 20 \mathrm{~m}$ on the outer bend of the small headland at Burdan's Gate (Fig. 5.5). 


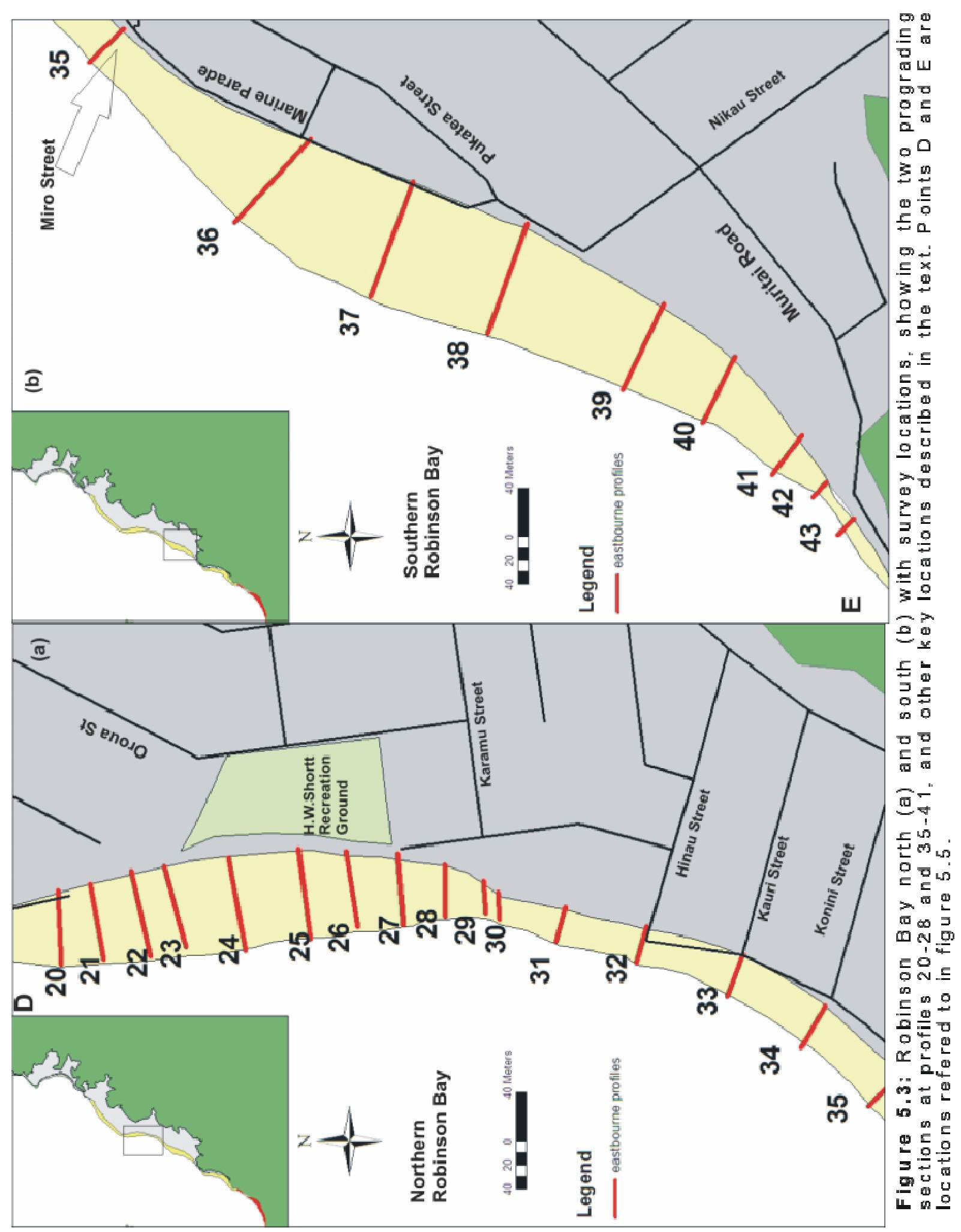




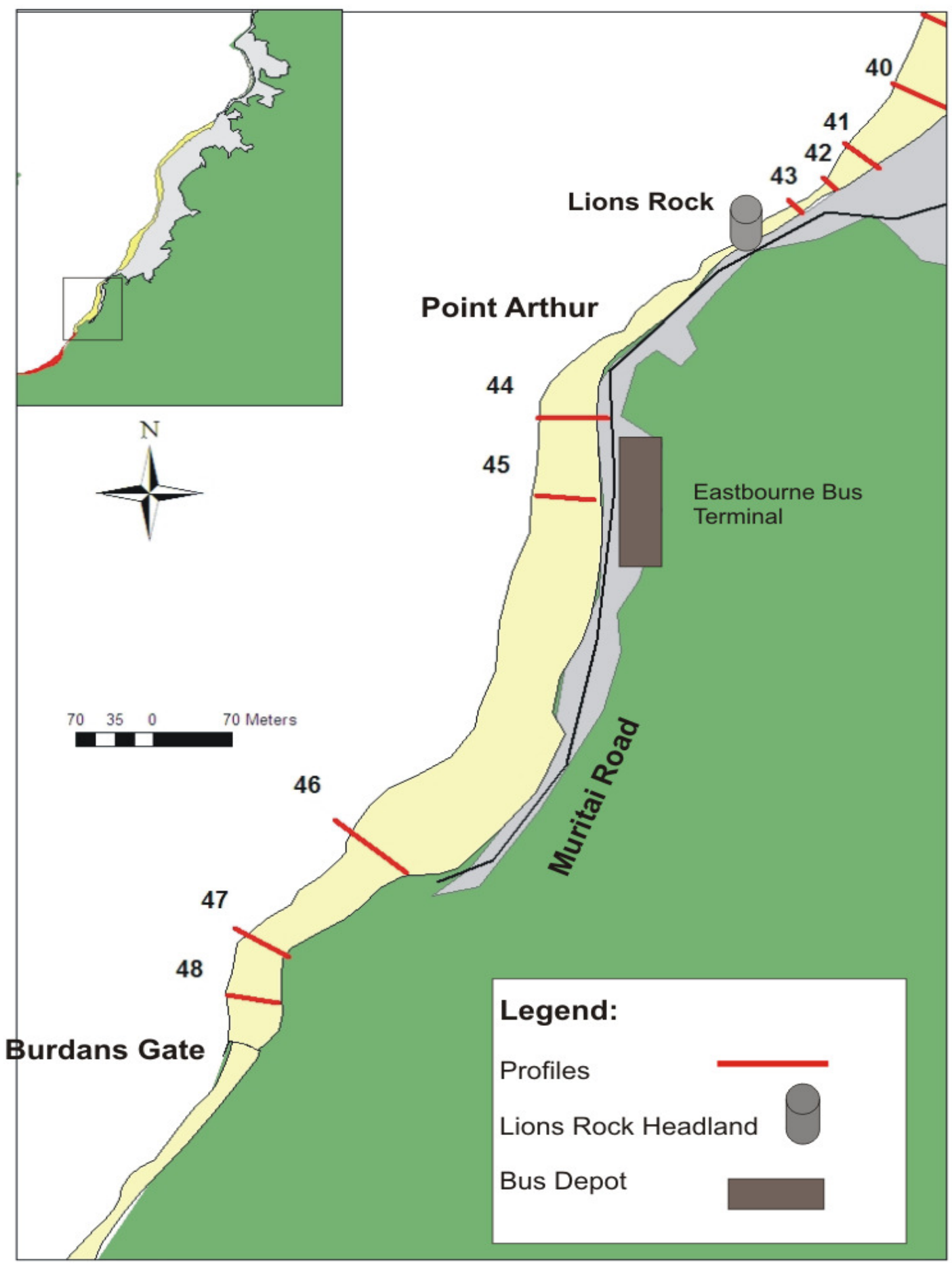

Figure 5.4: Location of Burdans Gate Profiles (44-48) showing Lions Rock, Burdans Gate and the bus depot described in the above text. 


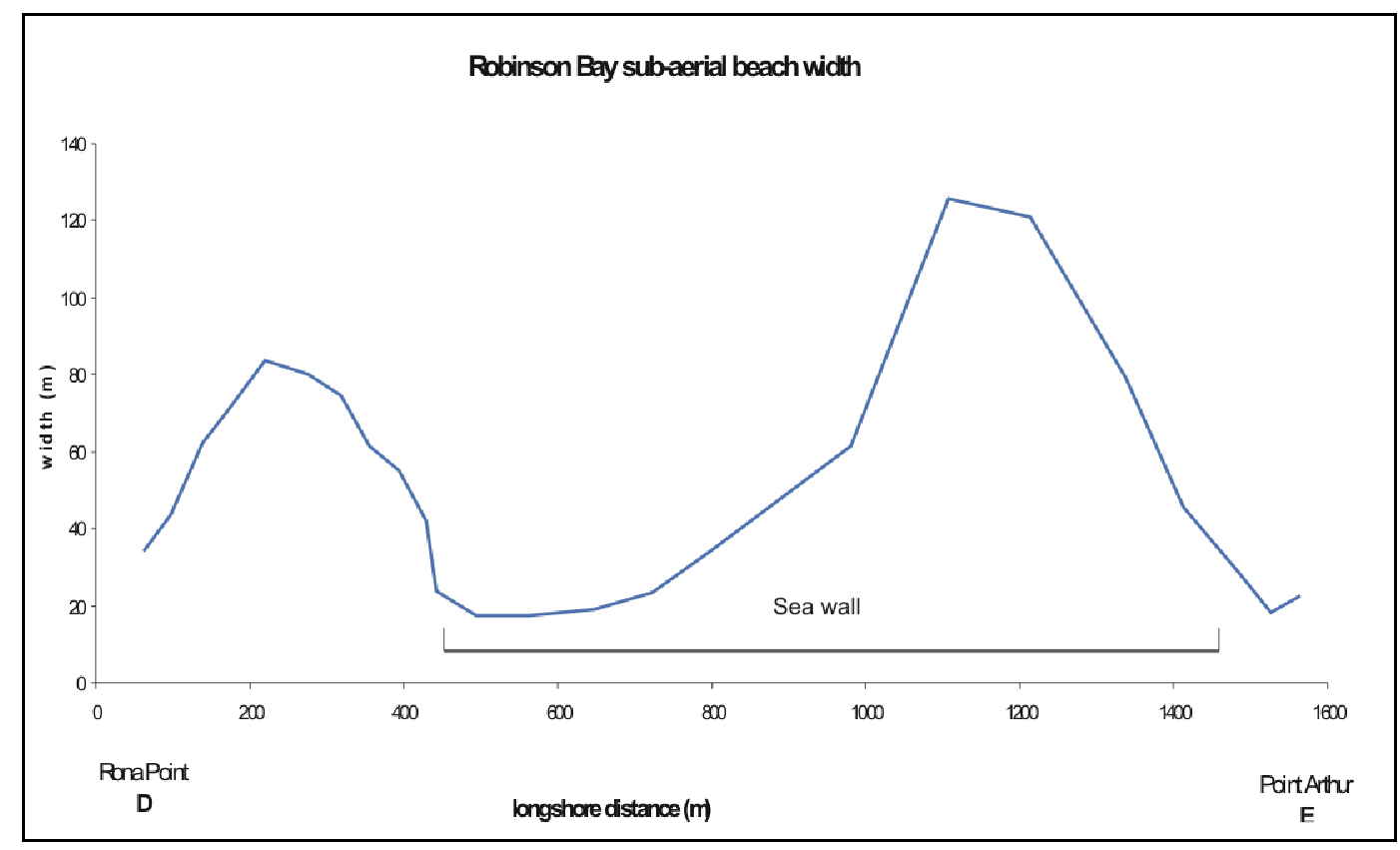

Figure 5.5: Subaerial beach width Robinson Bay moving north to south (left to right) from topographic surveying. Points $D$ and $E$ refer to locations in figure 5.3. Beach width is highly variable in this embayment ranging from $<20 \mathrm{~m}$ at the northern end of the seawall and immediately north of the headland at point Arthur, to $>100 \mathrm{~m}$ in the mid-southern part of the embayment adjacent to the southern half of the seawall.

These field measurements of width are compared here with the GIS analysis of beach widths from the 2008 aerial photographs, and were found to have similar values $( \pm 5.23 \mathrm{~m})$, between Days Bay and Point Arthur (Table 5.1), which is roughly proportional to the error associated with aerial photo analysis. The accuracy of the aerial photo analysis allows beach width to be analysed south of Burdans Gate, outside of the surveying area. South of Burdans Gate, beach width is again greatest in embayments and relatively narrow on headlands. There are several embayments between Kohangapiripiri Bay and Burdans Gate where significant sediment accumulation has occurred and substantial beach width has resulted. Fifteen profiles have been established as control points (Fig. 5.6). The widths of mid-bay profiles for Pencarrow (Table 5.2) are between 40 and $340 \mathrm{~m}$. Beach width is greatest at Kohangapiripiri Bay at the southern limit of the study site (Fig. 5.6), where a gravel barrier has formed in front of Lake Kohangapiripiri. With the exception of this barrier, widths are between 60 to $100 \mathrm{~m}$ in embayments and $\sim 40 \mathrm{~m}$ on the tips of headlands (Table 5.2). 
Table 5.1: Beach widths of selected profiles as calculated from field surveying and GIS analysis.

\begin{tabular}{|lcc|}
\hline Profile number & Surveyed beach width $(\mathrm{m})$ & GIS beach width $(\mathrm{m})$ \\
\hline Days Bay 8 & 35.08 & 30.82 \\
Rona 6 & 35.81 & 34.9 \\
Rona 16 & 38.22 & 34.34 \\
Robinson 24 & 83.63 & 78.4 \\
Robinson 41 & 27.97 & 32.34 \\
\hline
\end{tabular}




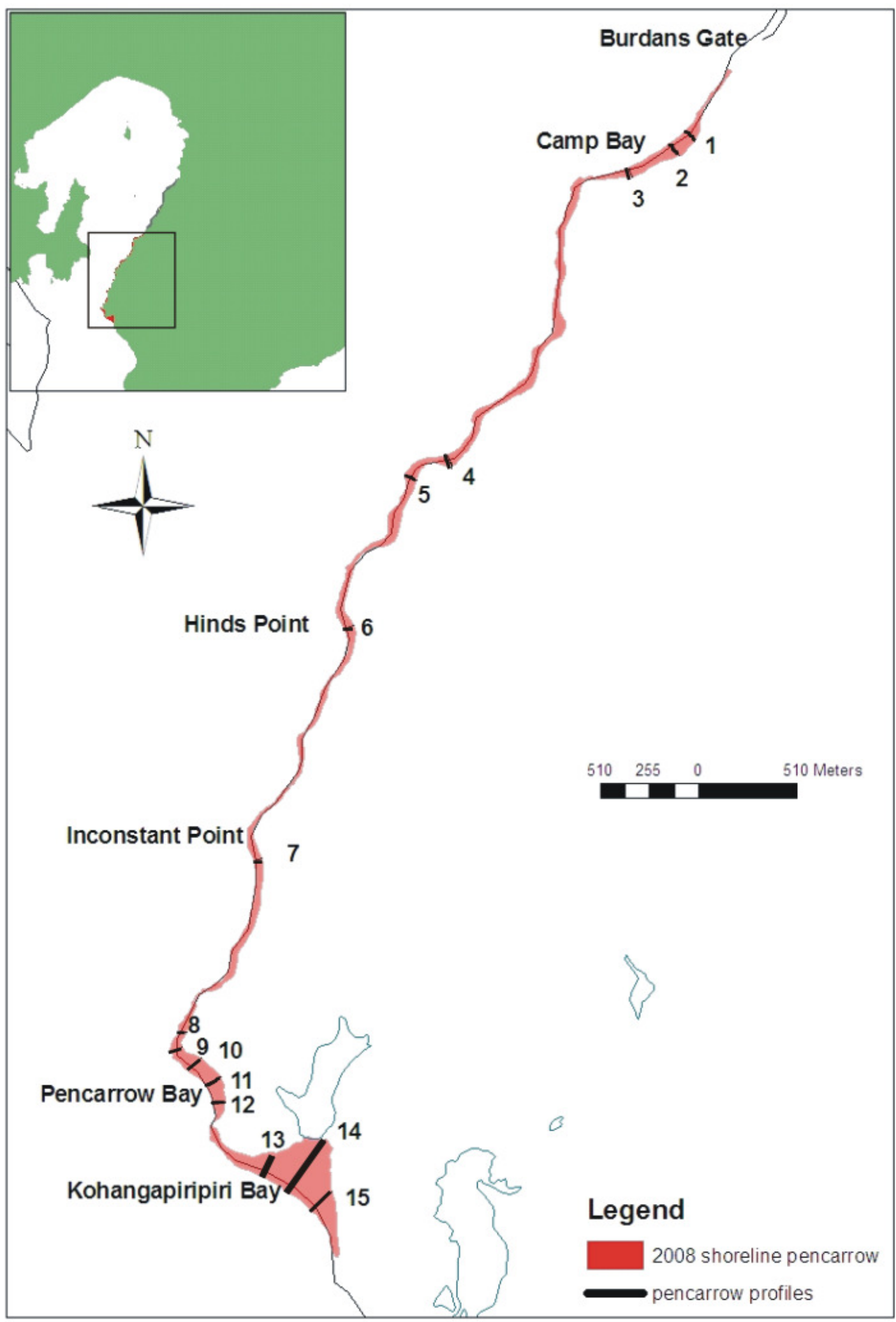

Figure 5.6: Location of Pencarrow profiles 1-15 used for GIS measuring of shore width. 
Table 5.2: Pencarrow Beach widths and beach orientation from 2008 aerial photographs.

\begin{tabular}{|c|c|c|c|c|c|}
\hline location & $\begin{array}{l}\text { profil } \\
\text { e }\end{array}$ & width $(m)$ & $\begin{array}{c}\text { azimuth } \\
\left({ }^{\circ}\right)\end{array}$ & $\begin{array}{l}\text { Bearin } \\
\mathrm{g}\end{array}$ & $\begin{array}{l}\text { Distance from Burdans Gate } \\
(\mathrm{m})\end{array}$ \\
\hline Camp Bay & $\begin{array}{l}1 \\
2 \\
3\end{array}$ & $\begin{array}{l}69.51 \\
82.25 \\
59.41\end{array}$ & $\begin{array}{l}261 \\
244 \\
229\end{array}$ & $\begin{array}{l}\text { SW } \\
\text { SW } \\
\text { SW }\end{array}$ & $\begin{array}{l}392 \\
499 \\
760\end{array}$ \\
\hline Pipes & $\begin{array}{l}4 \\
5\end{array}$ & $\begin{array}{l}63.13 \\
65.57\end{array}$ & $\begin{array}{l}243 \\
276\end{array}$ & $\begin{array}{l}\text { SW } \\
\text { NW }\end{array}$ & $\begin{array}{l}2753 \\
2989\end{array}$ \\
\hline $\begin{array}{l}\text { Hinds } \\
\text { Point }\end{array}$ & 6 & 58.4 & 314 & NW & 3910 \\
\hline $\begin{array}{l}\text { Inconstant } \\
\text { Point }\end{array}$ & 7 & 40.36 & 325 & NW & 5282 \\
\hline $\begin{array}{l}\text { Pencarro } \\
\text { w Bay }\end{array}$ & $\begin{array}{c}8 \\
9 \\
10 \\
11 \\
12\end{array}$ & $\begin{array}{l}40.18 \\
66.11 \\
95.95 \\
90.09 \\
63.06\end{array}$ & $\begin{array}{l}340 \\
339 \\
290 \\
225 \\
216\end{array}$ & $\begin{array}{l}\text { NW } \\
\text { NW } \\
\text { NW } \\
\text { SW } \\
\text { SW }\end{array}$ & $\begin{array}{l}6307 \\
6402 \\
6527 \\
6650 \\
6760\end{array}$ \\
\hline K. Bay & $\begin{array}{l}13 \\
14 \\
15\end{array}$ & $\begin{array}{l}132.76 \\
340.37 \\
150.29\end{array}$ & $\begin{array}{l}210 \\
253 \\
250\end{array}$ & $\begin{array}{l}\text { SW } \\
\text { SW } \\
\text { SW }\end{array}$ & $\begin{array}{l}7277 \\
7426 \\
7604\end{array}$ \\
\hline
\end{tabular}

\subsubsection{Cross sectional morphology}

As with beach width, field measurements of profile shape show longshore variation in morphology between bays in the south where the gravel front has been established, and the bays further north which are currently being exposed to initial stages of the gravel influx. Beach profiles in the southern stretches of Robinson Bay and near Burdans Gate are steep, reflective and broadly convex in shape. Northward, with distance into the harbour, profiles flatten out and berms become less distinct. The morphological variables of width (total and subaerial), change in elevation, foreshore slope and cross sectional area are presented in a summary table (Table 5.3), and a detailed account of the longshore morphological variation is presented in the below section, beginning with a description of the beach at Days Bay. 


\section{i. Days Bay}

Days Bay appears to maintain a low energy estuarine sandy beach character with a low tide terrace marked by a weak tidal berm. The northern section is narrow and erosional, as is characterised in profile 'Days Bay 1' (Fig. 5.7), and the southern section is beginning to adopt a MSG morphology with a steeper slope and more obvious high tide berm. In Rona Bay the beach develops a distinct high tide berm and sandy low tide terrace morphology (Fig. 5.7, Profiles Rona Bay 10, 15 and 19).

\section{ii. Rona Bay}

The backbeach zone of Rona bay is primarily sand dunes, with a break in slope at the base of the foredune, a gently sloping upper foreshore and a very distinctive break in slope at the high tide berm, where the berm face slope is between 12 to $21^{\circ}$. Average foreshore slopes are relatively high, but most fall between 5 to $12^{\circ}$, (Table 5.3) consistent with the findings of Kirk (1980). There is some morphological variation within Rona Bay, particularly toward the northern headland at Windy Point (Fig. 5.7 Rona Bay Profile 4) where the beach narrows and profile cross sectional areas are low $\left(<10 \mathrm{~m}^{2}\right)$. The influence of the Eastbourne Wharf and other anthropogenic coastal alterations can be observed in localised profile changes, for example, Profile 6 has a gentler slope $\left(3.9^{\circ}\right)$ as it has been modified to accommodate the construction of the Muritai Yacht Club. 


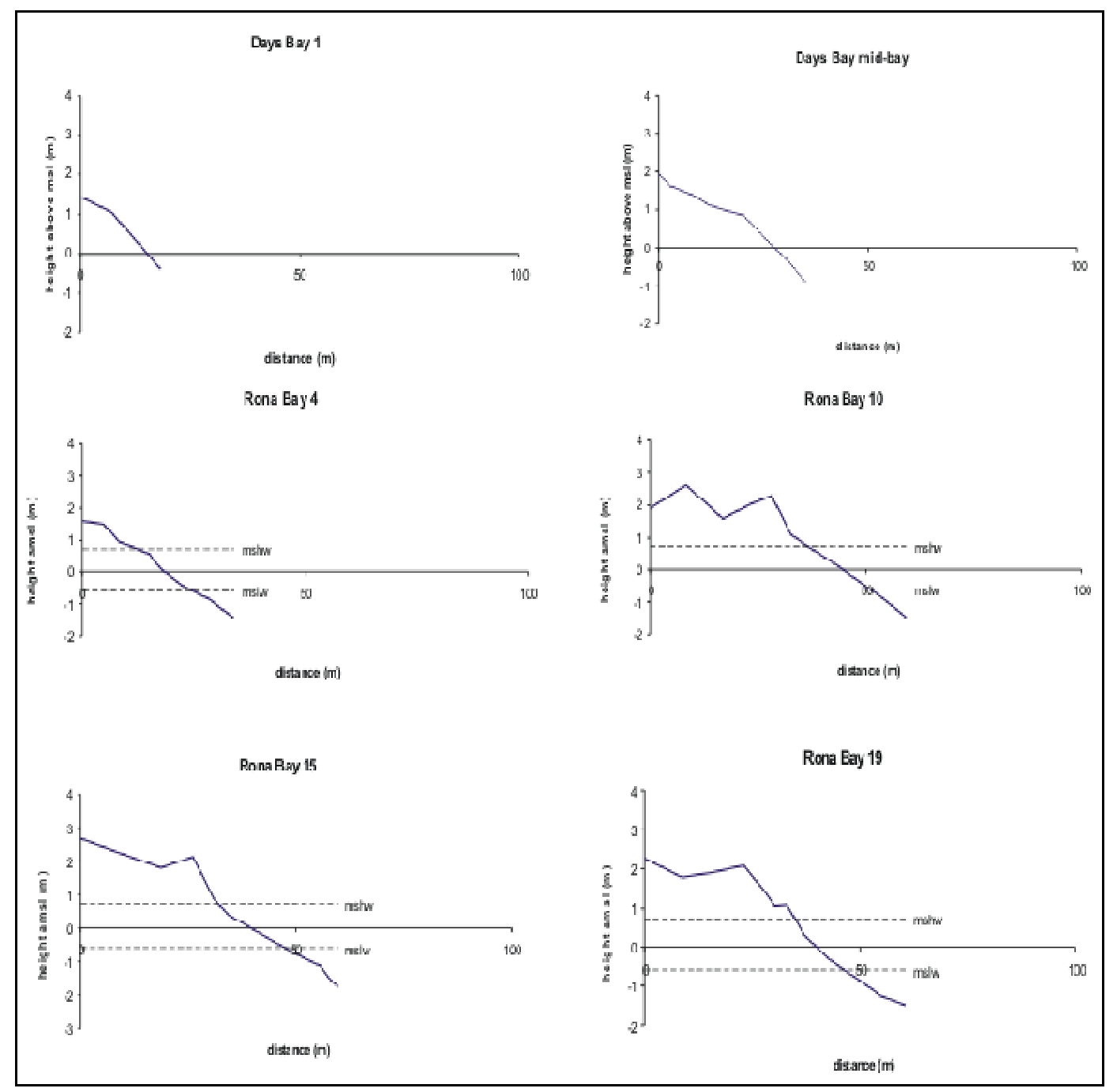

Figure 5.7: Representative beach profiles moving South from Days Bay and Rona Bay. Locations of profiles are shown in figure 5.1. Days Bay profiles are narrow $(10-35 \mathrm{~m})$ and relatively linear and featureless, Rona Bay profiles indicate the development of a convex gravel upper foreshore with high tide and storm berms separated from a flatter low tide terrace.

\section{iii. Robinson Bay}

Beach morphology is more variable further south in Robinson Bay, as seen in the profiles displayed in Figure 5.9, and the morphological variables (listed in Table 5.3). Profiles 30 to 41 Fig. 5.3b are situated on the section of beach backed by the concrete sea wall. South of this the beach is backed by a narrow grassed bank with a steep escarpment leading into the backbeach. North of the sea wall (Profiles 20-29, Fig. 5.3a), the backbeach zone is wide $(\sim 50 \mathrm{~m})$ and is backed by a boulder riprap adjacent to the recreation ground. These sea wall and revetment 
features in the backshore areas are of note as they differ from the natural dune backing observed in Rona Bay, and as such significantly alter the backbeach zones of these stretches of the beach from their natural form.

There are at least three different characteristic profile shapes present in Robinson Bay. The first of these is found at the two prograding sections, where profiles are broadly convex with lower mean foreshore slopes around 4 to $7.5^{\circ}$, and narrow less distinct low tide terraces (Fig. 5.9). Profiles 35 to 40 representing the southern prograding section show the development of a multi storm berm morphology with at least four storm berms present at the larger prograding section south of Miro Street (Fig. 5.3b). There is a distinct cusp morphology present in the area at the Recreation Ground, with high tide cusp spacings of approximately $10 \mathrm{~m}$ and $a$ and a second less obvious set of cusps at the storm berm spaced at $\sim 20 \mathrm{~m}$ (Fig. 5.8). However, it is noted that this cusp morphology has not developed on the southern prograding section (Fig. 5.8).

The second profile type (profiles $30-34$,) occurs between the two prograding sections where the beach profile narrows to 15 to $30 \mathrm{~m}$. These profiles are situated at the northern end of the sea wall between Miro St and Karamu St (Fig. 5.3a). Profile 30 (Fig. 5.9) is representative of the profiles surveyed through this part of the beach. They present a relatively small upper foreshore ( $\sim 6 \mathrm{~m}$ wide) beginning at the base of the sea wall, and a significant gently sloping low tide terrace (mean slope $3.5^{\circ}$ ) with an absence of any significant cusp development, a single moderately sloped storm berm and the indication of a weak high tide berm building on the current low tide terrace.

The third profile shape is south of the Miro St prograding section (Fig 5.3). As the beach narrows again heading into Point Arthur, beachface slope increases to 7 to $11^{\circ}$, and the profiles remain convex but are narrower with sharp berm crests and in certain areas the high tide berm has merged with the storm berm or was not present at the time of surveying, indicating that sections of the southern part of this embayment were in an erosional state 
(Fig. 5.9, Profile 40), perhaps in response to a preceding swell event scouring material in the lee of the Lions Rock headland. Additional to this, the morphology of these southern profiles is marked by a conspicuous obvious overwash trough landward of the berm, with the landward berm face tilting 2 to $6^{\circ}$ away from the shore.

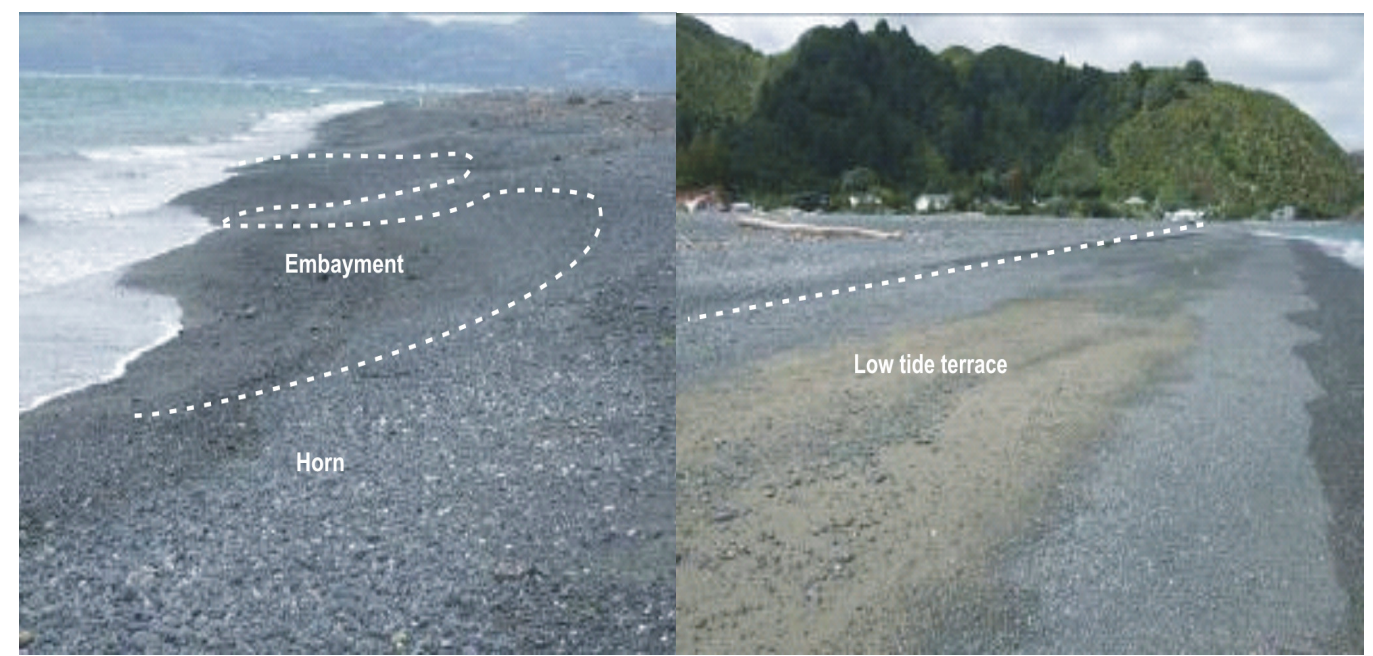

Figure 5.8: lower foreshores of the two prograding sections at the recreation ground looking north (left) and the southern prograding section south of Miro Street looking south (right), showing differences in cusp development. The northern progradation displays clear undulating cusp morphology, with coarser grained horns and finer grained embayments with patchy surficial sand. The southern prograding section presents a more uniform low tide terrace with little indication of cusp formation and alternating grain size zones.

\section{i.v. Burdans Gate - Pencarrow}

The beach between Point Arthur and Burdans Gate (identified in Figure 5.4, profiles 44 to 48) also displays the accretional multi-berm morphology with a steep gravel-dominated low tide terrace, and a substantial accumulation of material mid-embayment adjacent to the farm house at the end of Muritai Road. Morphology of Pencarrow beaches from field observations appears similar to that of the prograding sections in Robinson Bay With several embayments between exhibiting multi-berm morphology, with lower sloped foreshores and extensive backbeach areas. 


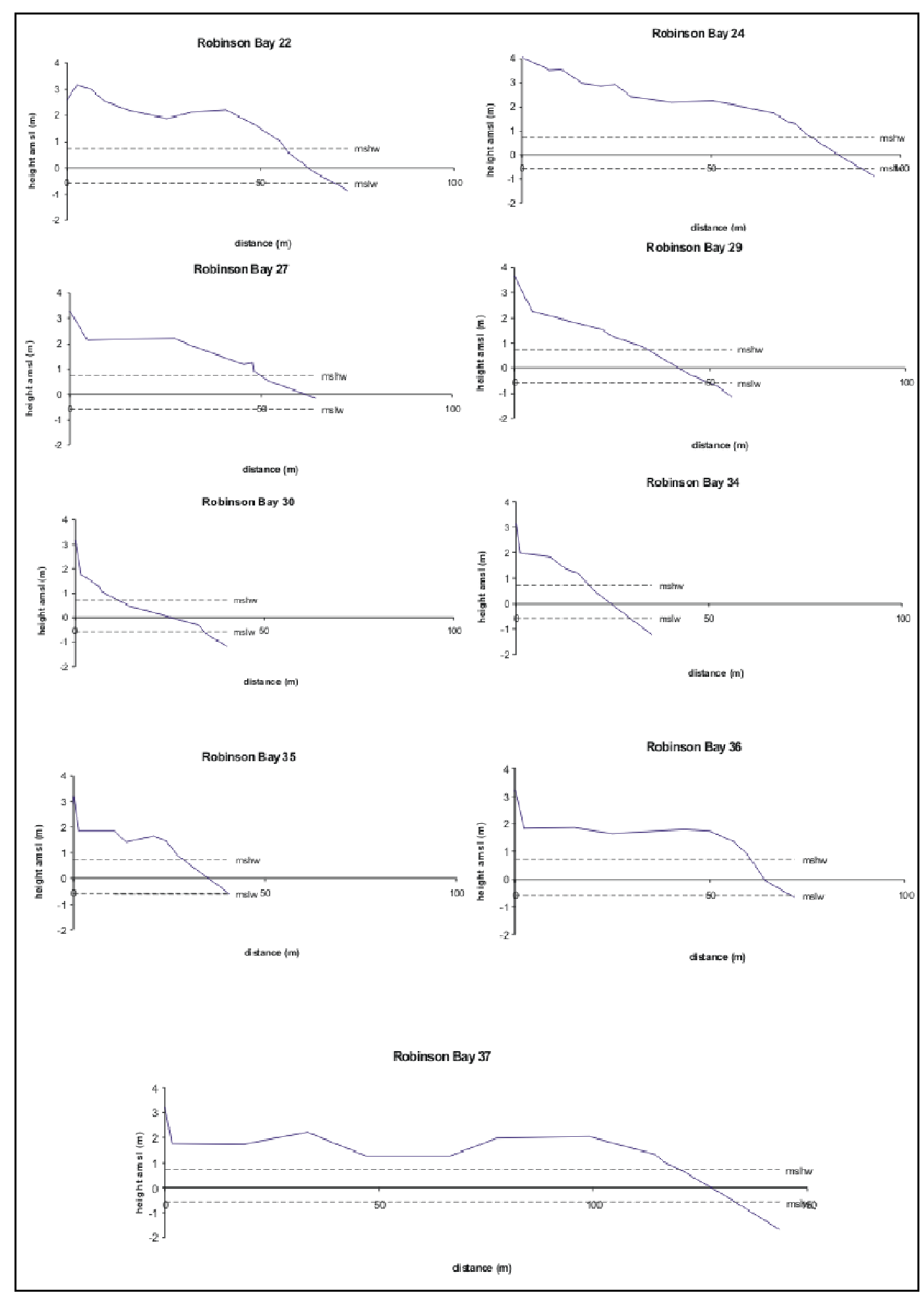




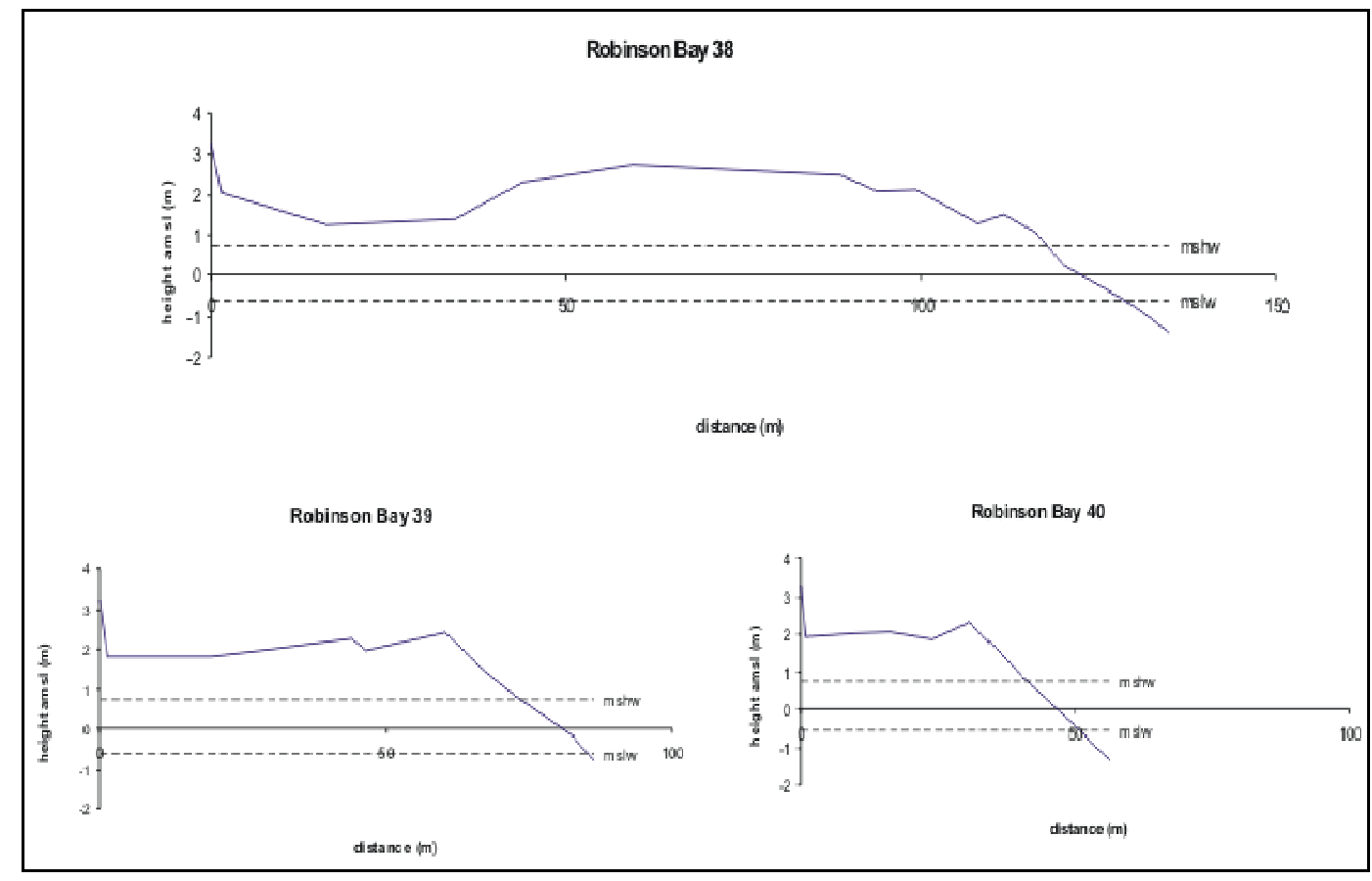

Figure 5.9: Characteristic Robinson Bay profiles from north to south. Profile locations are presented in figure 5.3a,b. These profiles exhibit a wide range of morphologies that have been divided into three categories: (1) wide accretional multi berm, (2) narrow linear seawall controlled, and (3) single-berm and erosive. This figure shows the transition between representative cross-shore morphologies through Robinson Bay.

Table 5.3: Morphological variables width, change in elevation, subaerial width, cross sectional area and slope for Rona and Robinson Bays, central Eastbourne.

\begin{tabular}{|c|c|c|c|c|c|}
\hline \multicolumn{6}{|c|}{ Rona Bay } \\
\hline Profile & $\begin{array}{l}\text { Surveyed total } \\
\text { width }(\mathrm{m})\end{array}$ & $\begin{array}{l}\text { change in } \\
\text { elevation }(m)\end{array}$ & $\begin{array}{l}\text { Sub-aerial } \\
\text { width }(\mathrm{m})\end{array}$ & $\begin{array}{c}\text { cross } \\
\text { sect. area } \\
\left(\mathrm{m}^{2}\right)\end{array}$ & $\begin{array}{l}\text { foreshore } \\
\text { slope }^{\circ}\end{array}$ \\
\hline 1 & 22.05 & 2.77 & 8.47 & 4.15 & 8.2 \\
\hline 2 & 24.13 & 3.05 & 9.72 & 7.17 & 9 \\
\hline 3 & 36.67 & 3.67 & 20.08 & 19.76 & 5.6 \\
\hline 4 & 34.08 & 3.07 & 18.55 & 17.65 & 6.3 \\
\hline 5 & 61.73 & 4.04 & 47.82 & 89.60 & 6 \\
\hline 6 & 51.82 & 2.24 & 35.81 & 26.48 & 3.9 \\
\hline 7 & 58.17 & 2.95 & 44.25 & 72.87 & 9.1 \\
\hline 8 & 61.50 & 3.20 & 45.50 & 61.29 & 7.2 \\
\hline 9 & 49.44 & 3.97 & 34.50 & 47.80 & 7.5 \\
\hline 10 & 59.40 & 3.35 & 44.64 & 72.81 & 8.5 \\
\hline 11 & 54.31 & 3.14 & 41.23 & 68.23 & 8.3 \\
\hline 12 & 51.95 & 3.24 & 39.18 & 62.49 & 9.5 \\
\hline 13 & 53.53 & 3.27 & 41.86 & 70.29 & 14 \\
\hline 14 & 62.31 & 4.32 & 41.07 & 65.44 & 7.1 \\
\hline 15 & 59.64 & 4.44 & 39.57 & 66.80 & 7.6 \\
\hline 16 & 58.35 & 4.56 & 38.22 & 66.17 & 7.6 \\
\hline 17 & 63.08 & 4.52 & 42.41 & 73.98 & 8.9 \\
\hline 18 & 52.13 & 3.52 & 37.04 & 58.29 & 6.4 \\
\hline 19 & 60.65 & 3.74 & 39.95 & 62.88 & 5.6 \\
\hline \multicolumn{6}{|c|}{ Robinson Bay } \\
\hline 20 & 42.26 & 2.74 & 33.91 & 52.93 & 6.8 \\
\hline 21 & 54.38 & 3.11 & 43.79 & 74.17 & 7.4 \\
\hline 22 & 72.59 & 3.44 & 62.38 & 121.38 & 6.3 \\
\hline 23 & 79.59 & 3.66 & 70.35 & 146.32 & 5.4 \\
\hline
\end{tabular}




\begin{tabular}{|lccccc|}
24 & 92.94 & 4.94 & 83.63 & 189.37 & 4.3 \\
25 & 82.06 & 4.28 & 79.96 & 152.15 & 4.0 \\
26 & 75.21 & 3.63 & 74.75 & 140.50 & 5.5 \\
27 & 64.25 & 3.43 & 61.67 & 100.93 & 9.8 \\
28 & 66.68 & 5.05 & 55.19 & 96.10 & 5.2 \\
29 & 55.58 & 4.80 & 42.03 & 63.48 & 4.7 \\
30 & 40.23 & 2.92 & 23.77 & 16.22 & 7.0 \\
31 & 37.59 & 3.20 & 17.61 & 13.46 & 7.5 \\
32 & 35.20 & 3.16 & 17.34 & 10.19 & 8.6 \\
33 & 31.79 & 3.19 & 19.13 & 19.76 & 6.6 \\
34 & 35.39 & 3.24 & 23.40 & 29.94 & 5.7 \\
35 & 40.74 & 2.42 & 34.00 & 45.53 & 6.8 \\
36 & 71.65 & 2.47 & 61.64 & 99.35 & 5.5 \\
37 & 143.44 & 3.45 & 125.70 & 202.14 & 4.7 \\
38 & 134.89 & 3.43 & 121.00 & 235.56 & 4.7 \\
39 & 86.20 & 2.59 & 79.46 & 141.47 & 7.6 \\
40 & 56.39 & 3.29 & 45.77 & 78.63 & 8.6 \\
41 & 33.71 & 2.79 & 27.97 & 37.31 & 8.2 \\
42 & 27.56 & 3.54 & 18.40 & 31.63 & 11.1 \\
43 & 27.01 & 3.45 & 22.72 & 28.70 & 6.5 \\
\hline
\end{tabular}

\section{v. Cross sectional area and beach volumes}

Calculated cross sectional area of the surveyed profiles and approximate beach volumes from Rona and Robinson Bay are presented in Tables 5.4 and 5.5. The approximate total subaerial beach volume for Eastbourne between Rona Bay Profile 1 and Robinson Bay Profile 43 is $200,000 m^{3}$, with the majority of the material located in Robinson Bay. Gibb (1975, 1979) calculated that the mean accumulation rate of gravel north of the Orongorongo River between 1460 and 1974 was $7200 \mathrm{~m}^{3} / \mathrm{yr}$. At this rate it would take approximately 28 years for the $200,000 \mathrm{~m}^{3}$ of sediment to accumulate at Eastbourne. Much of the Eastbourne material would predate this however, especially in Rona Bay in the north.

Table 5.4: Cross sectional area of subaerial beach profiles and volumes of sections between profiles for Rona Bay.

\begin{tabular}{|c|c|c|c|}
\hline \multicolumn{2}{|c|}{$\begin{array}{c}\text { cross sectional area } \\
\left(\mathrm{m}^{2}\right)\end{array}$} & $\begin{array}{c}\text { average cross sec. } \\
\text { area }\end{array}$ & volume of section $\left(\mathrm{m}^{3}\right)$ \\
\hline 1 & 4.15 & 5.66 & 435.58 \\
2 & 7.17 & 13.46 & 1656.19 \\
3 & 19.76 & 18.71 & 1758.48 \\
4 & 17.65 & 53.63 & 3217.62 \\
5 & 89.60 & 58.04 & 2960.07 \\
6 & 26.48 & 49.67 & 4073.29 \\
7 & 72.87 & 67.08 & 5768.88 \\
8 & 61.29 & 54.55 & 3709.06 \\
9 & 47.80 & &
\end{tabular}




\begin{tabular}{|c|l|l|l|}
10 & 72.81 & 60.31 & 2472.51 \\
11 & 68.23 & 70.52 & 2186.12 \\
12 & 62.49 & 65.36 & 2222.24 \\
13 & 70.29 & 66.39 & 2058.09 \\
14 & 65.44 & 67.87 & 3189.66 \\
15 & 66.80 & 66.12 & 1719.12 \\
16 & 66.17 & 66.49 & 2459.95 \\
17 & 73.98 & 70.08 & 2803.00 \\
18 & 58.29 & 66.14 & 1785.65 \\
19 & 62.88 & 60.59 & 2483.99 \\
\hline total & & & 46959.48 \\
\hline
\end{tabular}

Table 5.5: Cross sectional area of subaerial beach profiles and volumes of sections between profiles for Robinson Bay.

\begin{tabular}{|c|c|c|c|}
\hline \multicolumn{2}{|c}{$\begin{array}{c}\text { cross sectional area } \\
\text { profile }\end{array}$} & $\begin{array}{c}\text { average cross sec. } \\
\text { area }\end{array}$ & \begin{tabular}{c} 
volume of section $\left(\mathrm{m}^{3}\right)$ \\
\hline 20
\end{tabular} \\
21 & 52.93 & 57.91 & 3532.21 \\
22 & 74.17 & 63.55 & 2287.80 \\
23 & 121.38 & 97.78 & 3911.00 \\
24 & 146.32 & 133.85 & 4283.28 \\
25 & 189.37 & 167.85 & 8224.44 \\
26 & 152.15 & 170.76 & 9903.89 \\
27 & 140.50 & 146.32 & 5999.27 \\
28 & 100.93 & 120.72 & 4828.68 \\
29 & 96.10 & 98.52 & 3645.18 \\
30 & 63.48 & 79.79 & 2633.19 \\
31 & 16.22 & 39.85 & 478.23 \\
32 & 13.46 & 14.84 & 786.50 \\
33 & 10.19 & 11.82 & 851.29 \\
34 & 19.76 & 14.97 & 1227.88 \\
35 & 29.94 & 24.85 & 1938.14 \\
36 & 45.53 & 37.73 & 2980.85 \\
37 & 99.35 & 72.44 & 13184.23 \\
38 & 202.14 & 150.75 & 19295.59 \\
39 & 235.56 & 218.85 & 22979.25 \\
40 & 141.47 & 188.51 & 23564.23 \\
41 & 78.63 & 110.05 & 8143.76 \\
42 & 37.31 & 57.97 & 4348.09 \\
43 & 31.63 & 34.47 & 1275.54 \\
\hline total & 28.70 & 30.17 & 1116.17 \\
\hline
\end{tabular}




\subsection{Temporal Changes}

\subsubsection{Short term and seasonal variation}

Beach morphology responds to changes in wave energy (Woodroffe, 2002), and seasonal variation in frequency of southerly storm events would be expected to result in profile changes in the study site. Additionally, it is reasonable to expect that the rapid transport of gravel size sediment through this area would contribute to distinct morphological changes over the period of a year. To assess the variability of beach morphology in response to these and other time dependent forcings, repeat surveys were conducted in northern Robinson Bay adjacent to the recreation ground (Figs. 5.10 and 5.11.) These surveys demonstrate seasonal variation in cross shore beach morphology, with net erosion of the southern end of the beach between April 2008 and August 2009 (Fig. 5.10), whilst concomitantly accretion occurred in the northern end (Fig. 5.11). This suggests that the dominant sediment transport direction is longshore rather than offshore as material is translated downdrift and redeposited at a faster rate than it is being lost out of the system.

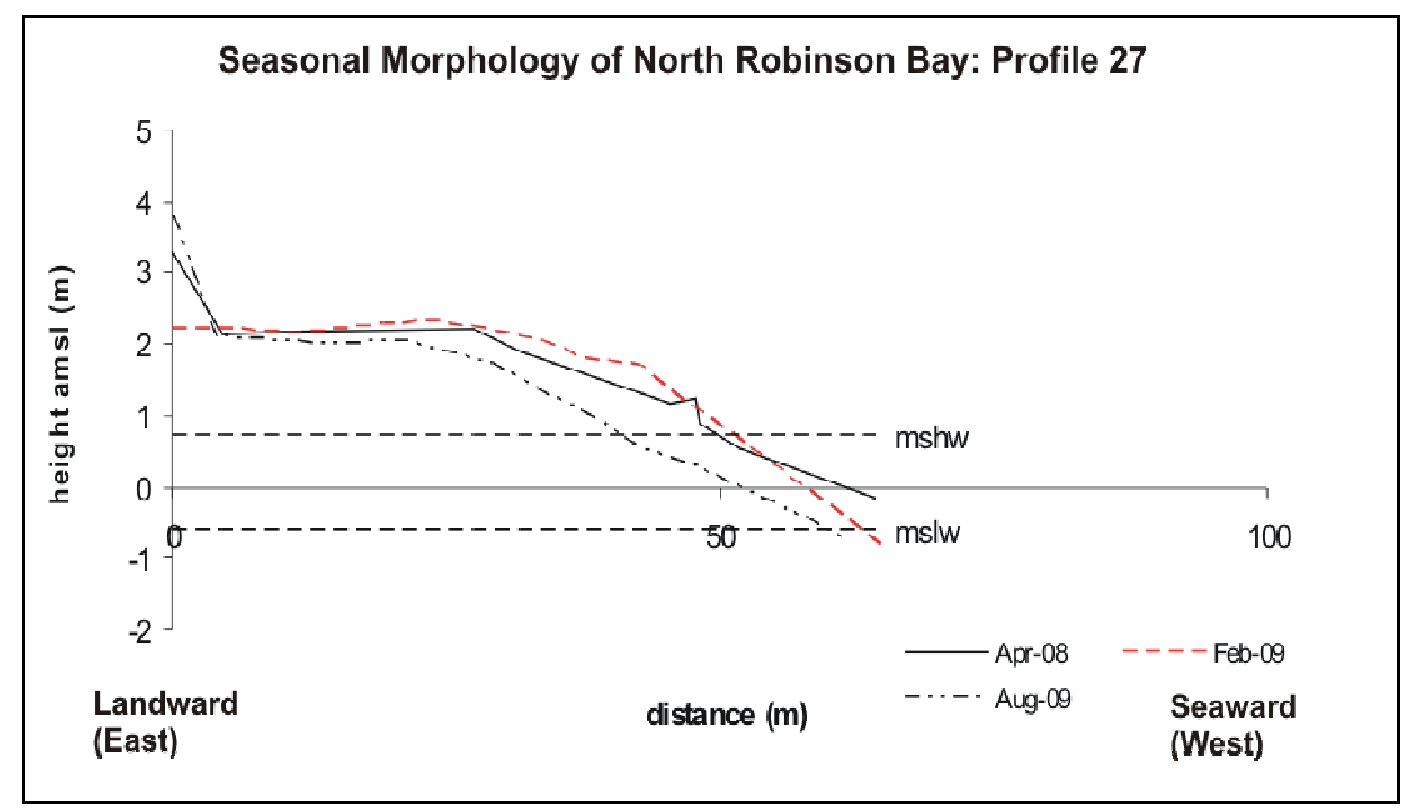

Figure 5.10: Beach profile 27 located at southern end of Recreation Ground showing repeat survey results between April 2008 and August 2009. The beach profile has shown minor accretion heading into summer through April 2008 to February 2009, followed by significant erosion from February to August 2009. 


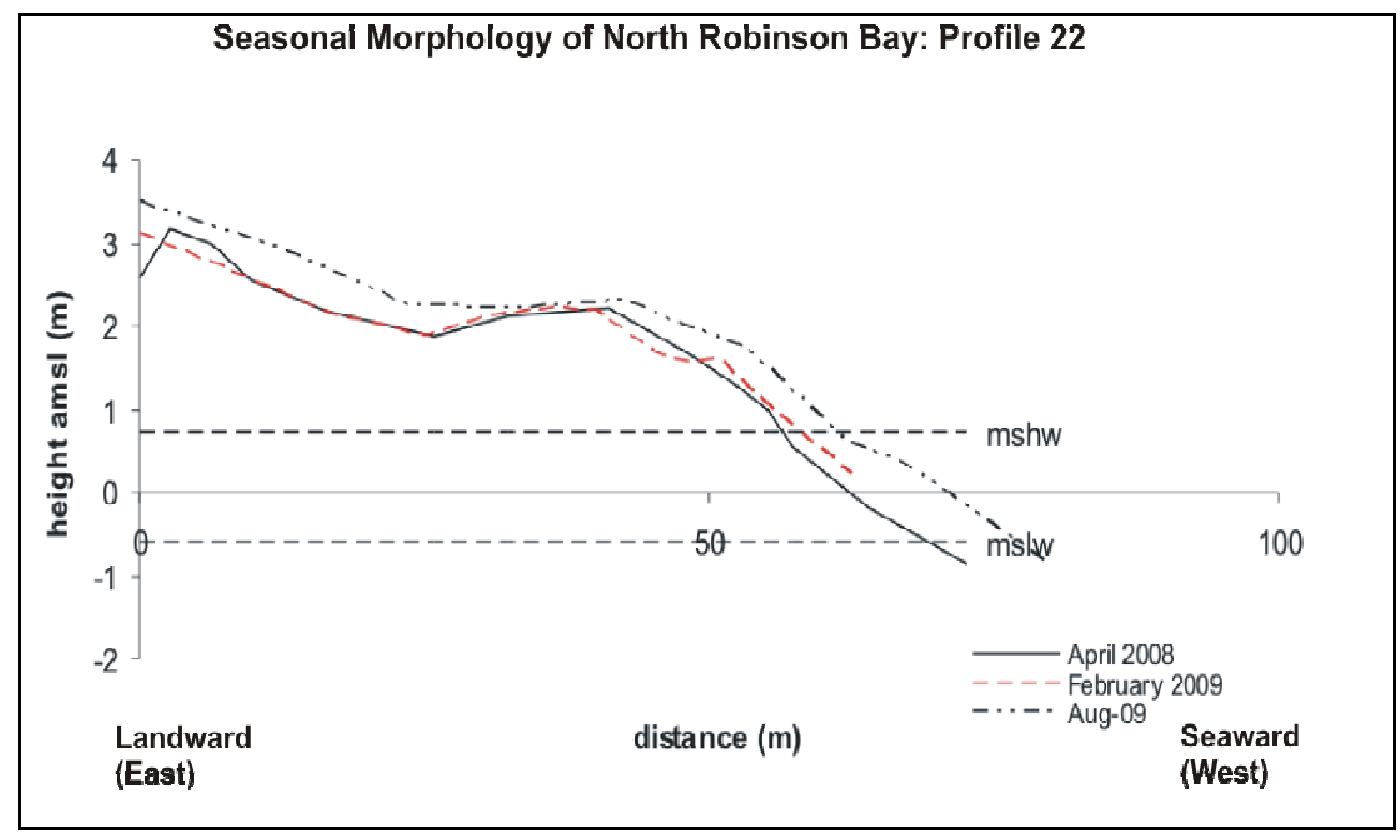

Figure 5.11: Beach profile 22, located $220 \mathrm{~m}$ north of profile 27 at the northern end of the Recreation Ground showing repeat survey results. Conversely to Figure 5.10, this profile has shown net accretion through the entire seasonal cycle. It is located downdrift from Profile 27and the accretion is likely to be the function of the erosion seen at Profile 2.2.

\subsubsection{Decadal scale shoreline position}

\section{i. Historic beach width - Days Bay}

The position of the Days Bay shoreline has fluctuated $\sim 10 \mathrm{~m}$ between 1941 and 2008 (Fig. 5.12). Overall width peaked ca. 1954, with a period of erosion at the northern end from 1975 onwards, and a recent shoreline advance at the southern end of the beach is observed as gravel has begun infiltrating the bay. Beach width in the middle of the bay has remained fairly constant. Surveyed beach width is combined (dashed line, Fig. 5.12) and is known to be slightly narrower in the north but is consistent with the aerial photo measured widths through mid and southern Days Bay, ranging 20-35m. 


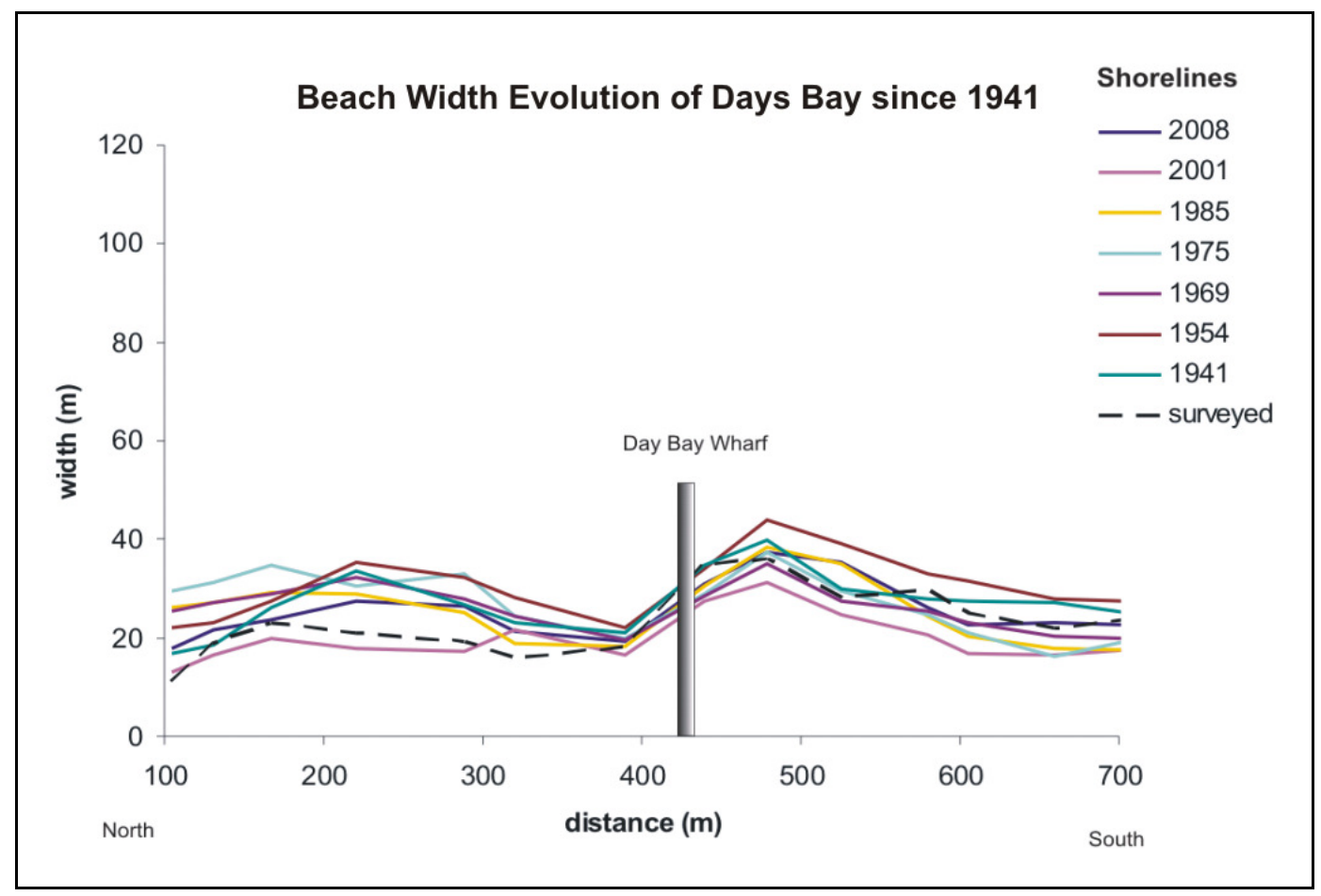

Figure 5.12: Days Bay beach widths calculated from aerial photographs showing minor width fluctuations $(\sim 10 \mathrm{~m})$ over the period of analysis. Surveyed width is combined to show accuracy of both measured techniques.

\section{ii. Historic beach width - Rona Bay}

Rona Bay has shown an overall trend of accretion between 1941 and 2008 of up to and over 40m (Fig 5.13). The 1941 photographs place the shoreline landward of the current dune line which accounts for the negative values through central Rona Bay during this period. Following this, width has shown an overall increase through to 2008, with fluctuations in the range of $\sim 10 \mathrm{~m}$ though all sections of the Bay. This shoreline advance has been most prominent through 1941-1969. For this embayment the most obvious section of advance is punctuated by the Eastbourne wharf where width is increased to the south. 


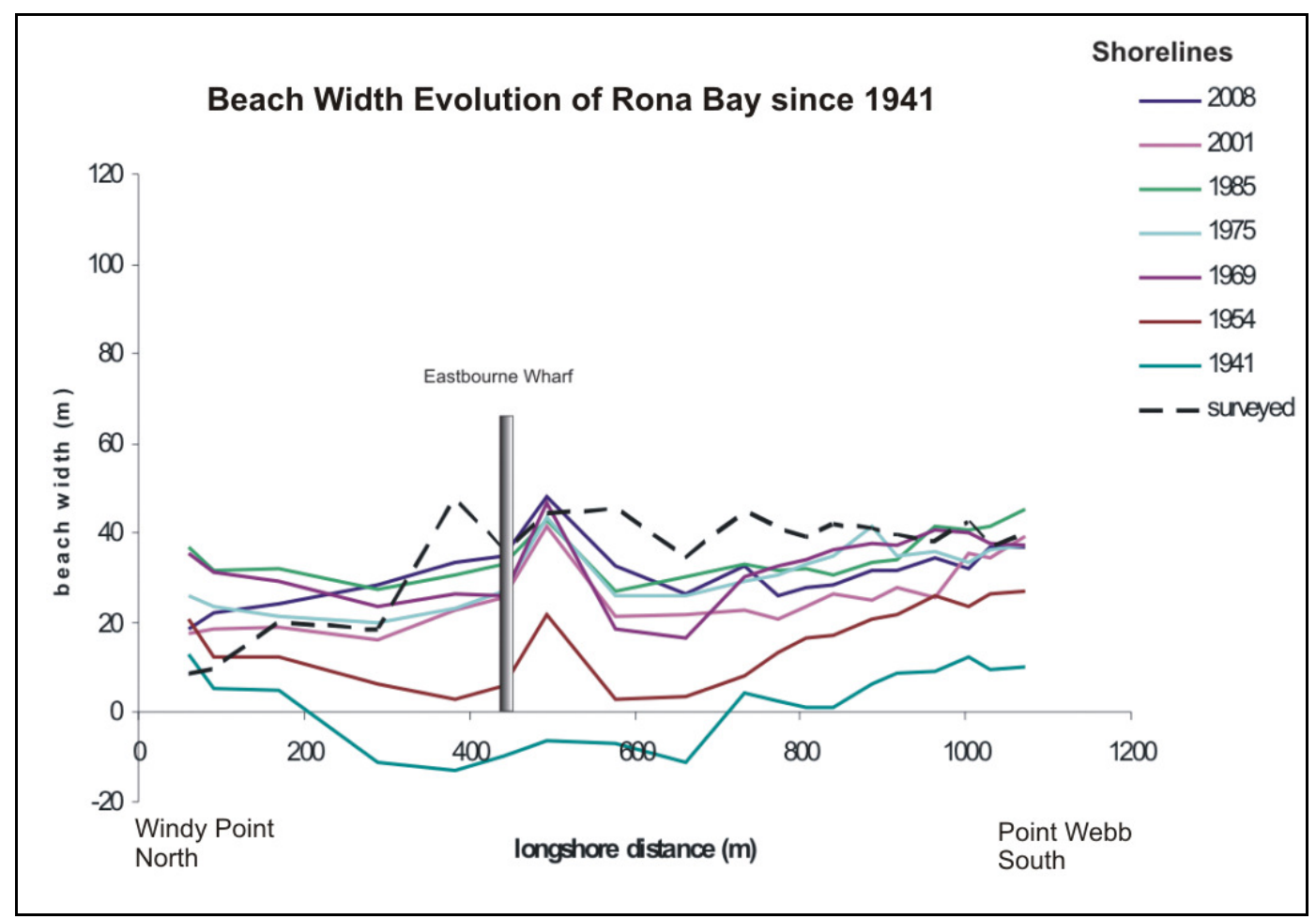

Figure 5.13: Rona Bay beach widths calculated from aerial photographs. Horizontal shoreline movement of $>40 \mathrm{~m}$ has been observed as well as the effect of the wharf on sedimentation. Surveyed width is similar right through the section aside from at Windy Point, where is is significantly lower $(<10 \mathrm{~m})$.

\section{iii. Historic beach width - Robinson Bay}

The most significant shoreline width changes have occurred in Robinson Bay (Fig 5.14), where there has again been a net increase in beach width of up to $60 \mathrm{~m}$ through the Recreation Ground area and up to $120 \mathrm{~m}$ through the southern prograding section at Miro Street. Width remained low through the southern part until 1985, when beach width increased dramatically from 20 to $100 \mathrm{~m}$. The northern progradation has generally shown increased width, but with reduction shown in the period from 1969 to 1975 followed by accretion from this time to the present. 


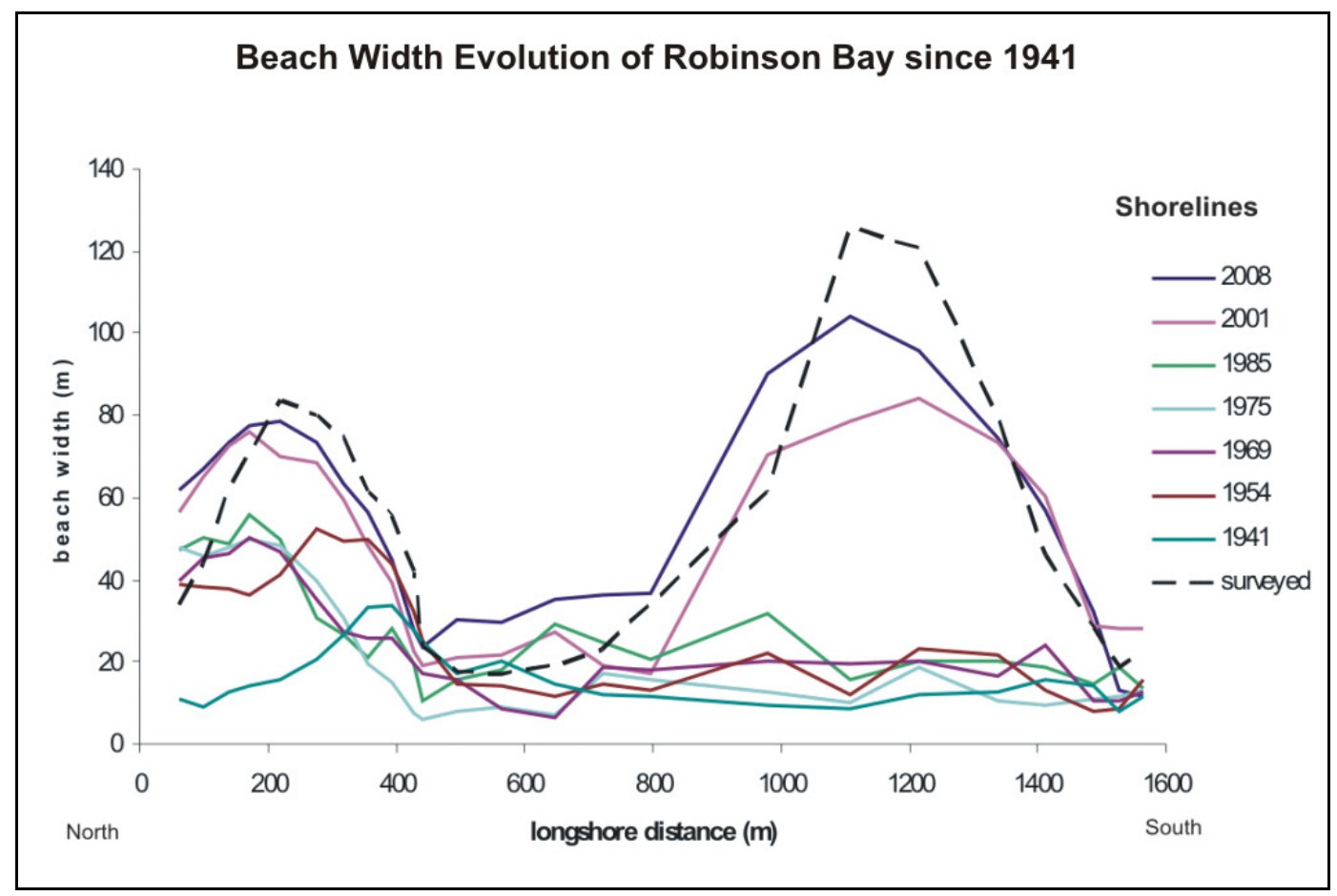

Figure 5.14: Robinson Bay beach widths calculated from aerial photographs.

\section{i.v. Historic beach width - Pencarrow}

Beach widths for Pencarrow have also increased overall in the sites measured as part of the aerial photo shoreline analysis (Table 5.6). The southernmost embayment measured is Kohangapiripiri Bay (K.Bay, Table 5.6), which has shown a significant initial increase in width from 19411954, and has then remained at a constant width through to 2008. Northward, Pencarrow Bay has shown the same pattern in the same timeframe. Beach width at Inconstant Point and Hinds Point to the north has initially decreased, before increasing from 1969 and becoming constant. 'The Pipes' and Camp Bay have experienced significant width increase from 1985, and have then remained constant. These width figures are given in metres in Table 5.6. 
Table 5.6: data from Pencarrow Section aerial photo analysis. Values are given in meters.

\begin{tabular}{|c|c|c|c|c|c|c|c|c|}
\hline \multicolumn{9}{|c|}{ Year } \\
\hline location & profile & 2008 & 2001 & 1985 & 1975 & 1969 & 1954 & 1941 \\
\hline \multirow[t]{3}{*}{ Camp Bay } & 1 & 69.51 & 68.88 & 60.45 & 26.29 & 28.55 & 21.72 & 17.6 \\
\hline & 2 & 82.25 & 79.8 & 43.89 & 16.71 & 33.41 & 17.06 & 24.8 \\
\hline & 3 & 59.41 & 47.94 & 62.78 & 14.64 & 21.49 & 10.48 & 20.31 \\
\hline \multirow[t]{2}{*}{ Pipes } & 4 & 63.13 & 61 & 51.6 & 16.81 & 23.21 & 8.67 & 0.88 \\
\hline & 5 & 65.57 & 61.8 & 57.18 & 39.11 & 31.87 & 24.95 & 38.33 \\
\hline Hinds Point & 6 & 58.4 & 56.57 & 65.04 & 58.12 & 40.04 & 17.93 & 37.97 \\
\hline $\begin{array}{l}\text { Inconstant } \\
\text { Point }\end{array}$ & 7 & 40.36 & 48.84 & 32.79 & 38.9 & 19.81 & $\begin{array}{c}\text { no } \\
\text { data }\end{array}$ & 44.75 \\
\hline \multirow[t]{5}{*}{$\begin{array}{l}\text { Pencarrow } \\
\text { Bay }\end{array}$} & 8 & 40.18 & 48.45 & 38.9 & 51.1 & 46.44 & $\begin{array}{c}\text { no } \\
\text { data }\end{array}$ & 33.16 \\
\hline & 9 & 66.11 & 67.73 & 42.17 & 71.17 & 62.01 & data & 37.52 \\
\hline & 10 & 95.95 & 97.44 & 80.59 & 99.65 & 93.41 & data & 67.01 \\
\hline & 11 & 90.09 & 98.24 & 79.49 & 102.55 & 94.77 & data & 59.47 \\
\hline & 12 & 63.06 & 79.16 & 46.96 & 59.66 & 56.98 & data & 42 \\
\hline \multirow[t]{3}{*}{ K. Bay } & 13 & 132.76 & 121.69 & 125.18 & $\begin{array}{l}\text { no } \\
\text { data }\end{array}$ & 133.56 & $\begin{array}{l}\text { no } \\
\text { data }\end{array}$ & 73.47 \\
\hline & 14 & 340.37 & 337.32 & 339.28 & data & 347.18 & $\begin{array}{l}\text { no } \\
\text { data }\end{array}$ & 248.17 \\
\hline & 15 & 150.29 & 146.54 & 146.06 & data & 146.96 & data & 57.44 \\
\hline
\end{tabular}

\subsubsection{Historic beach erosion/accretion}

The overall trend of beach width through the entire littoral cell over the time of analysis has been one of beach accretion (Fig. 5.15) Days Bay has been variable, but Rona and Robinson Bays and Pencarrow have shown net progradation of between 20 and $60 \mathrm{~m}$, and up to $100 \mathrm{~m}$ of accretion has occurred at the southern prograding section in Robinson Bay. This is illustrated in Figure 5.15 Which shows cumulative accretion/erosion for the shoreline between Days Bay and Hinds Point between 1941 and 2008 


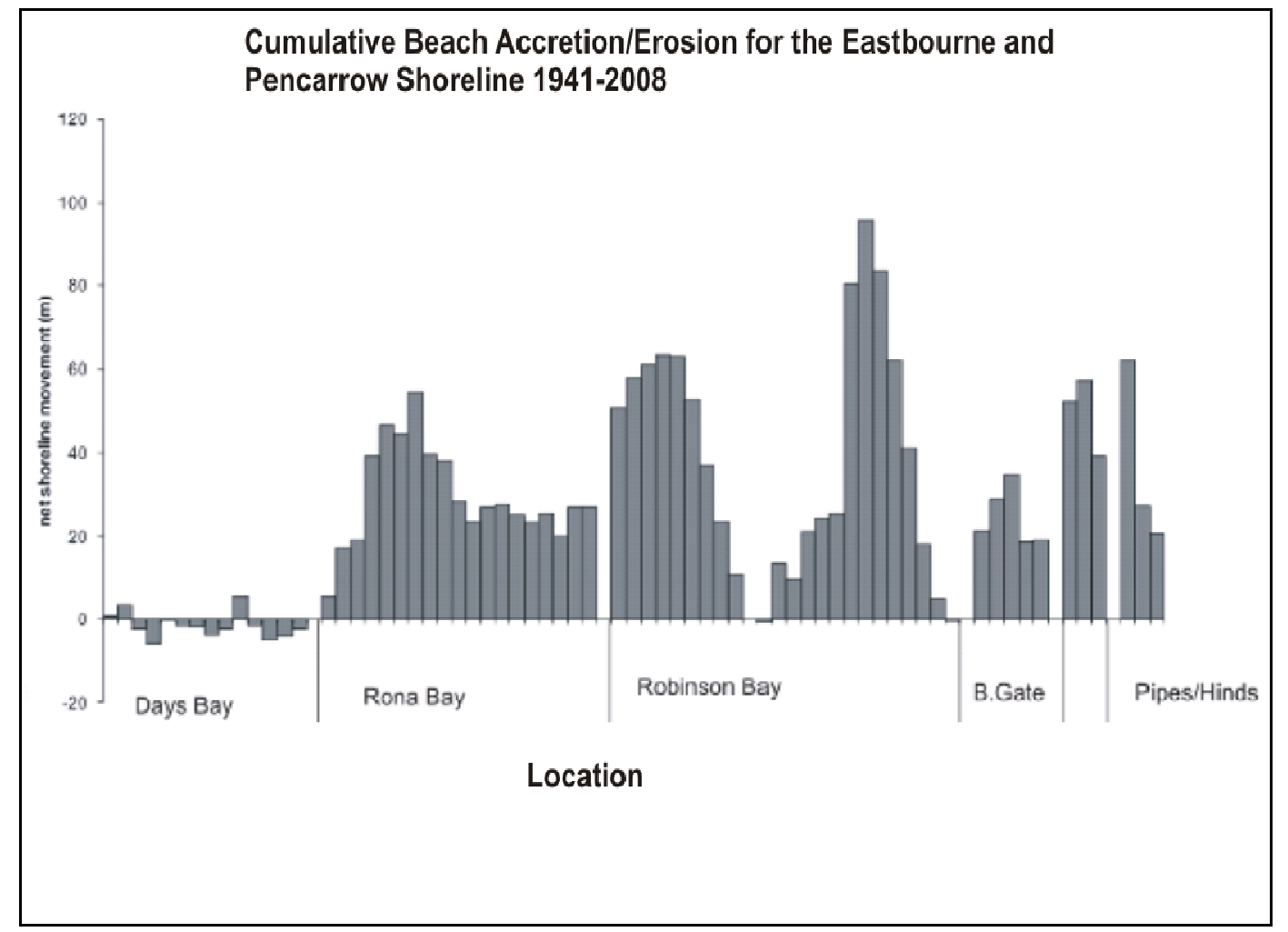

Figure 5.15: graph depicting cumulative beach accreation for the entire study area.

The average annual rates of this beach accretion/erosion for central Eastbourne (from Days Bay to Burdans Gate) are presented in Figure 5.16 and have been compared to those calculated by Hastie (1989). For the time period 1941-1969, beach width change rates have varied from -5 to $1.5 \mathrm{~m} / \mathrm{yr}$, consistent with Hastie's (1989 findings). The direction of shoreline movement through 1969 - 1985 is more variable. The findings of this study show more erosion through Robinson Bay than was indictated by Hastie, but the rate of movement remains in the range of -1.5 to $1.5 \mathrm{~m} / \mathrm{yr}$. The Rates between 1985 and 2008 are substantially higher through Robinson Bay at between 0.5 and $4 \mathrm{~m} / \mathrm{yr}$ and the predominant direction of movement has been in the form of beach accretion (Fig 5.16). 


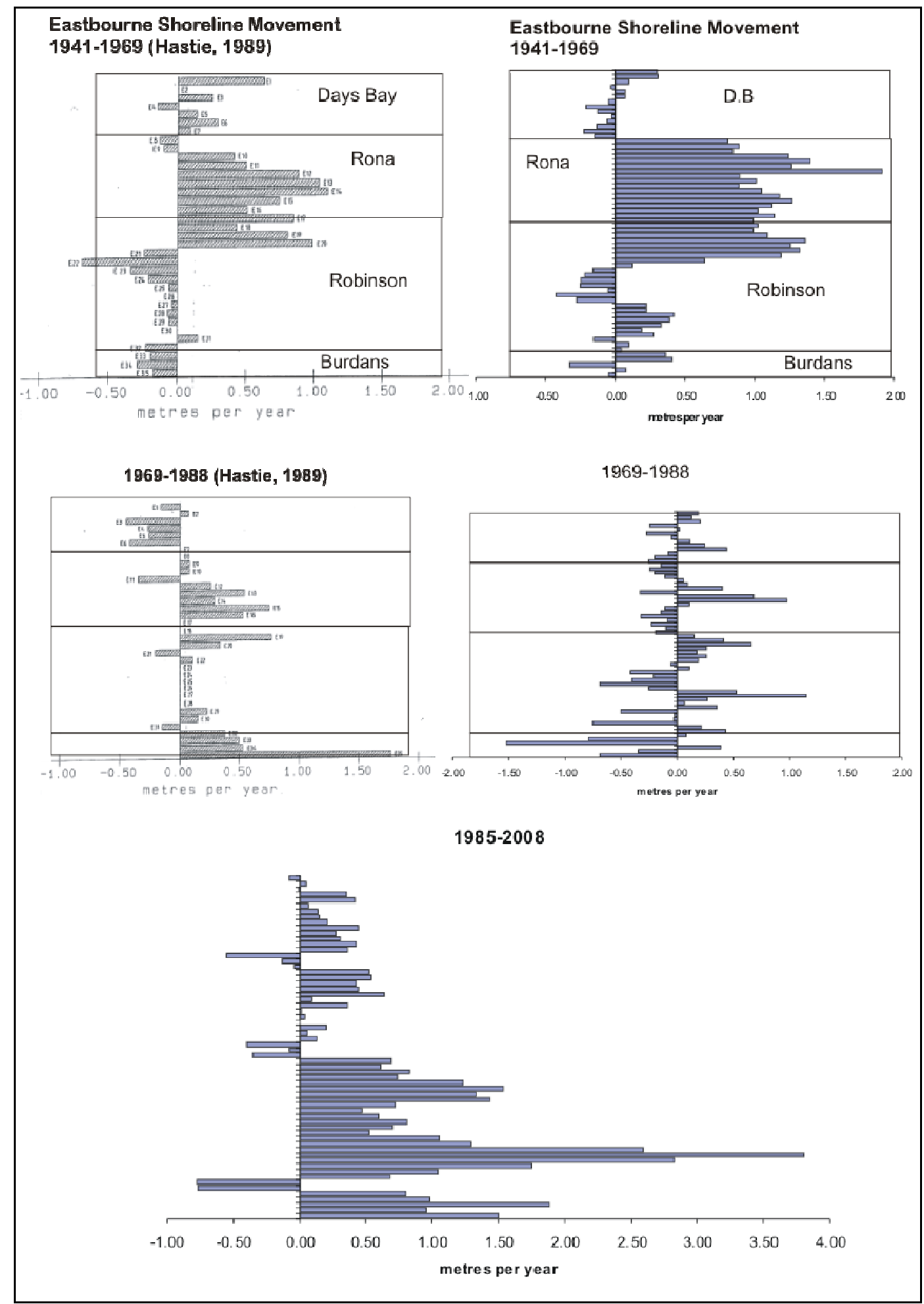

Figure 5.16: Average annual rates of shoreline movement for Eastbourne (Days Bay to Burdans Gate) (Adapted from Hastie, 1989). The rate of movement, in $\mathrm{m} / \mathrm{yr}$, is plotted on the $x$-axis. The $y$-axis represents individual profiles moving southward from Days Bay. 


\subsubsection{Gravel Front Northern Migration Rates}

The position of the northern extent of the gravel front was estimated from the aerial photo sets to establish approximate rates of movement. Between 1855 and 1941 the gravel front had traveled close to $10 \mathrm{~km}$ and the northern limit was situated near the tip of Pencarrow head, north of Pencarrow Bay (Fig. 5.17). By 1975 it had reached "The Pipes" north of Hinds Point, having traveled a further $3.4 \mathrm{~km}$ north over 34 years. Matthews $(1980 \mathrm{a}, \mathrm{b})$ had located the front $\sim 880 \mathrm{~m}$ north of the 1975 photobased location (Fig. 5.17). By 1985 it had entered Camp Bay, the large embayment immediately south of Burdans Gate; and between 1985 and 2008 the gravel front has shifted a further $4.5 \mathrm{~km}$ to its current position in south Days Bay. Table 5.7 shows the distance of the gravel front migration between photographs and approximate annual northern migration rates as established from the aerial photos. The average annual rate of movement of $0.17 \mathrm{~km} / \mathrm{y}$ is significantly lower than the $0.42 \mathrm{~km} / \mathrm{y}$ recorded by Matthews (1980a,b), which was calculated using a an equation based on the change of distance between the front and a fixed marker peg over the period of a year from 1978-79. The aerial photo analysis utilized in this study allows for the estimation of migration rates on the basis of a longer documented record of change, and therefore gives a rate more representative of the entire period of coastal adjustment. 


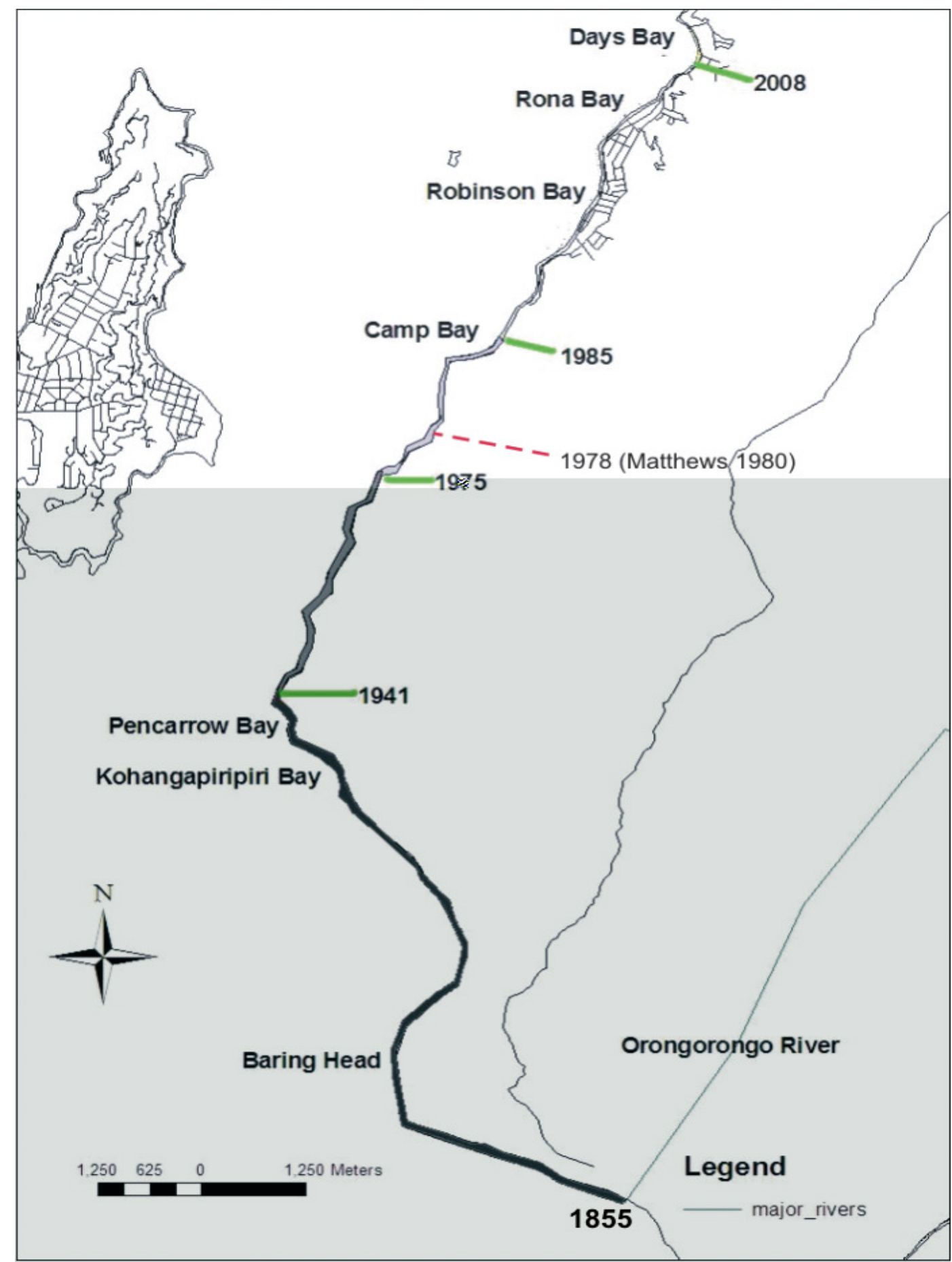

Figure 5.17: Location of gravel front northern extent through time showing the relative migration rates of the gravel component and the 1978 gravel location suggested by Matthews (1980b). The current limit is at Days Bay, $20 \mathrm{~km}$ north of the Orongorongo sediment source. 
Table 5.7: net alongshore movement of gravel front from Orongorongo River between 1941-2008.

\begin{tabular}{|c|c|c|c|}
\hline Year & Distance $(\mathrm{m})$ & Cumulative $(\mathrm{m})$ & annual rate $(\mathrm{m} / \mathrm{y})$ \\
\hline $1855-1941$ & 9805 & 9805 & 114 \\
$1941-1975$ & 3396 & 13200 & 100 \\
$1975-1985$ & 2595 & 15795 & 259 \\
$1985-2008$ & 4571 & 20367 & 199 \\
\hline
\end{tabular}

\subsubsection{Temporal changes in beach area}

Approximate beach area measurements calculated in ArcGIS have shown that overall, beach area has increased between 1941 and 2008 from $\sim 337000 \mathrm{~m}^{2}$ to $\sim 610000 \mathrm{~m}^{2}$ (Table 5.8). Days Bay beach area peaked around 1954 at around $2229 \mathrm{~m}^{2}$ and has steadily declined until 2001, before increasing slightly in 2008. Eastbourne beach between Windy Point and Burdans Gate has increased in area from approximately $100,000 \mathrm{~m}^{2}$ in 1941 to $200,000 \mathrm{~m}^{2}$, and the measured Pencarrow shoreline has also doubled in area between 1941 and 2001, before declining slightly into 2008 as material is transferred north into Eastbourne.

Table 5.8: shoreline areas calculated in GIS for Days Bay, Eastbourne and Pencarrow.

\begin{tabular}{|c|c|c|c|c|}
\hline \multicolumn{5}{|c|}{ shoreline area $\left(\mathrm{m}^{2}\right)$} \\
\hline year & davs bay & eastbourne & pencarrow & total \\
\hline 1941 & 1952 & 102162 & 232990 & 337104 \\
1954 & 2229 & 116748 & - & - \\
1969 & 1931 & 120289 & 293367 & 415587 \\
1975 & 1910 & 108449 & - & - \\
1985 & 1848 & - & 403303 & - \\
2001 & 1402 & 175451 & 419566 & 596419 \\
2008 & 1780 & 200566 & 408447 & 610793 \\
\hline
\end{tabular}




\subsection{Sedimentology}

\subsubsection{Grain size analysis}

\section{i. Overview}

The Eastbourne beaches are composed of a bimodal distribution of gravels ranging from cobbles $>-6 \Phi$ down to fine sands $<3.5 \Phi$. Grain size is highly variable through the Robinson and Rona Bay sites, but the samples collected from Days Bay in the north are considerably finer than those found in Eastbourne and southern Days Bay. In Rona Bay immediately south of Windy Point the beach is composed of pebblecobble size gravel through the foreshore with a sand dune field present in the backshore zone (Fig. 5.18a). Moving south, a sandy low tide terrace is present with sporadic pebbles, with a distinct break in slope at the high tide berm, with coarse pebbles on the berm face, and fine pebbles/coarse granules landward of the storm berm (Fig. 5.18b).

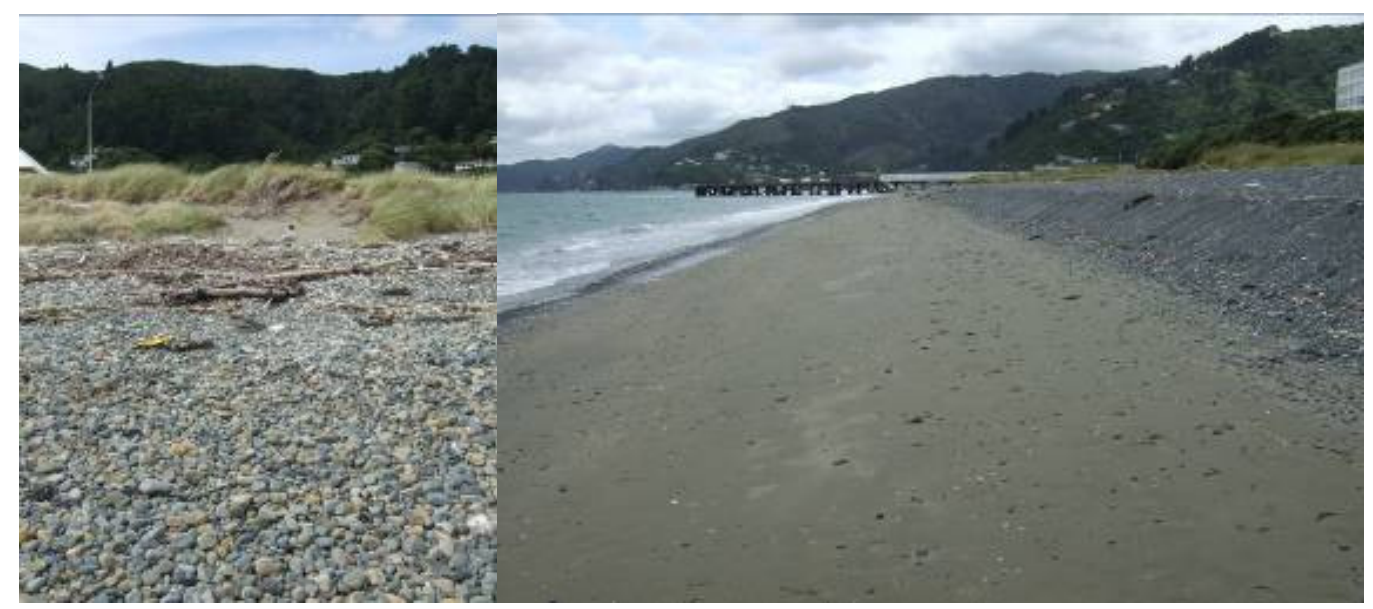

Figure 5.18: Rona Bay variation in sediment size and morphology. (A) profile 2 looking landward to dunes. Beach is narrow and consists of cobbles and pebbles backed by sandy dune system. (B) Rona Bay south of Eastbourne Wharf. Beach width is $30-40 \mathrm{~m}$, morphology shows clear gravel berm and coarse backbeach with dunes clearly separated from sandy low tide terrace.

Northern Robinson Bay maintains backbeach zones of sand size sediment with sporadic grassed dunes to the north of the Recreation Ground. South of the Recreation Ground, backbeach and foreshore sediment is dominated by gravel. Pockets of sand appear mostly on the low tide terrace, with the remainder of the beach alternating between pebble and 
granule sized clasts. The statistical parameters calculated for the sediment samples are given below to show this spatial variation in more detail, beginning with mean grain size.

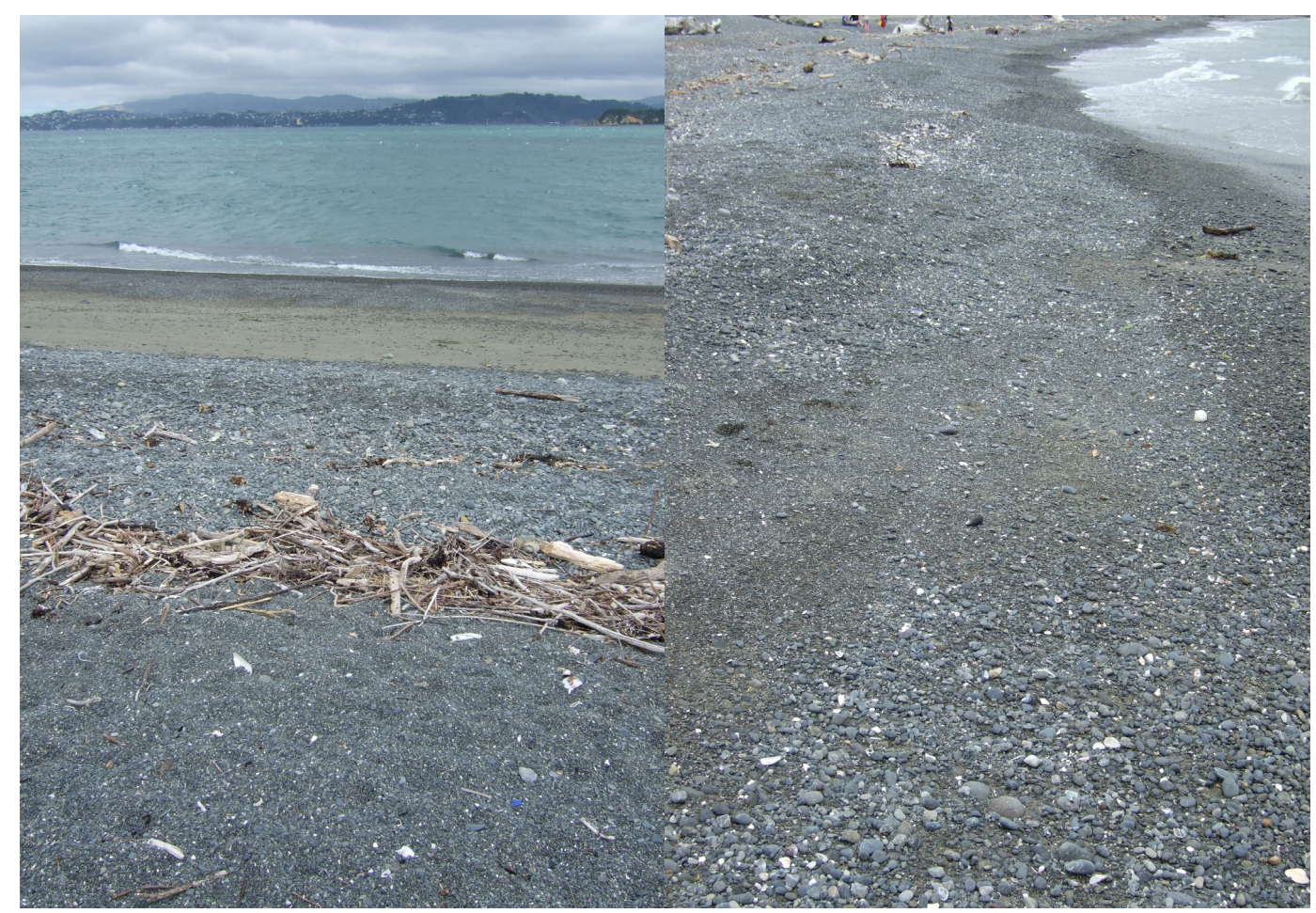

Figure 5.19: Robinson Bay. Figure, right, illustrates the dominance of gravels on this beach, as discussed in the text. Figure left shows a pocket of sand in the lowtide terrace.

\section{ii. Mean Grain Size}

Mean grain sizes for all samples were calculated and plotted against distance to show longshore variation (Fig. 5.20). Samples a and b are taken from the backbeach, $c$ from the midbeach and $d$ and $e$ from the low tide and/or swash zone areas. There is a gradual reduction in mean grain size with distance north towards Days Bay. The northernmost samples have mean grain sizes ranging from 2 to $-2 \Phi$ The coarser mean grain size samples for Days Bay are samples $d$ and e (Fig. 5.20) representing the swashzone. The central sites show a greater cross shore variation in mean size with an average size of $-2 \Phi$. The southern Transects 7, 8 and 9 are coarse with mean grain sizes ranging between -1 and $-5 \Phi$ (Fig. 5.20) and are less variable, with an absence of predominantly sand samples compared to the northern and central sites. 


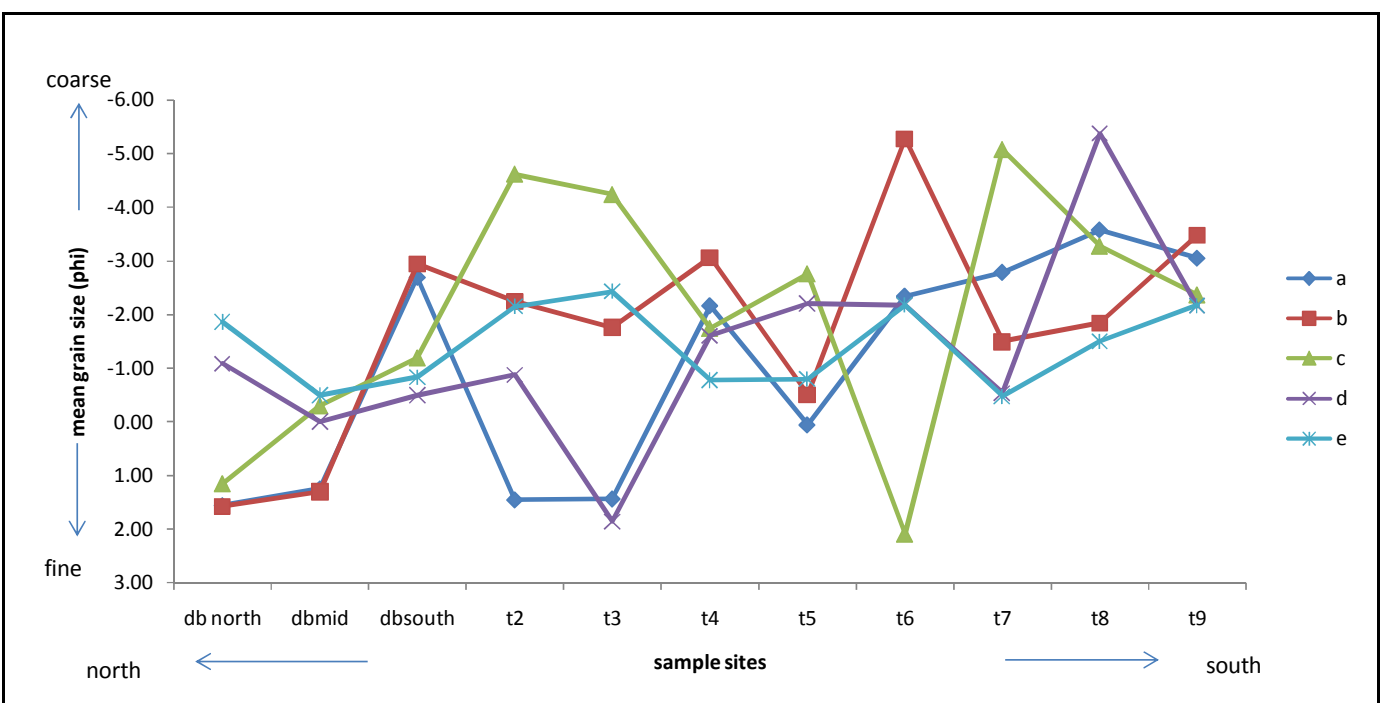

Figure 5.20: Longshore variation in grain size for all transects. Series a-e represent samples located from different points along the beach profiles, with a being the most landward backbeach sample, through to $d$ or e representing the most seaward sample, generally from the swash zone.

The surface sediment in the northern and central sections of Days Bay consists of predominantly medium to fine sand in the range of $0 \Phi$ to $3.5 \Phi$. Samples from transect DB1 is located in the extreme north of the bay adjacent to the Ferry Road bus stop and DB2 is located south of the wharf in the centre of the bay where the beach is widest. Samples $A$ and $B$ are taken from the back beach area of these profiles. Samples DB1A and B have mean grain sizes of $1.56 \Phi$ and $1.57 \Phi$ and are both moderately well sorted with 0.70 standard deviation values. Samples $2 \mathrm{~A}$ and B are slightly coarser but still fall within the medium sand category with mean grain sizes of $1.25 \Phi$ and $1.3 \Phi$, and are less well sorted with sorting values of 1.21 and 1.22. Grain size increases further seaward along the profiles showing the impact of a gravel lag and the influence of the storm water drain in the north of the bay. In the extreme south of the bay is the beach is composed of a mixture of sand and pebble sized sediment. The back beach area is significantly coarser than samples 1 and $2 \mathrm{~A}$ and $\mathrm{B}$. The back beach samples taken from this profile have mean grain sizes of $2.69 \Phi$ and $-2.95 \Phi$, are poorly to moderately sorted and positively skewed. The low tide and swash zone sediment in this southern section is comprised of $0 \Phi$ to $-0.5 \Phi$ very coarse sand intermixed with a coarse fraction of pebbles. 
The sediment collected from the very north of Rona Bay (figure) is composed of pebbles and cobbles throughout the active beachface, with a sand dune system located in the backbeach area. The sediment in the extreme north (Profile T1, Fig. 4.4, Chapter 4) is similar in appearance to that in the swash zone of northern Days Bay with coarser material and the presence of discoloured possibly local sourced gravel. The dune sand from transect 1 has a mean grain size of $1.53 \Phi$ and is very poorly sorted and positively skewed. Transects 2 and 3 are also backed by the dune system that shows slight increase of grain size with distance south. Transect 3 is aligned with the Rata St intersection in southern Rona Bay and has a distinct sandy lowtide terrace and high tide/storm gravel berm morphology backed by dunes. The northern section of Robinson Bay (transects 4 and 5 ) is more variable with large proportions of sand mixed through the backbeach areas and the low tide and swash zones. Southern Robinson Bay exhibits cross-shore zonation of sediment size, with pebbles $(>3.5 \Phi)$ on the storm berms and small pebbles to granules (approx. $-1.49 \Phi$ to -2.6 )

Mean grain size analysis provides a basic description of textural variation, but alone cannot sufficiently account for variation in grain size. Other size parameters have been calculated for these Eastbourne samples and can be plotted against mean grain size to add validity to the grain size data. Sorting and mean size have been plotted (Fig. 5.20) to examine longshore and cross shore variation in all the samples. The results of this comparison show that most of the samples were with mean grain sizes between $-4 \Phi$ and $0 \Phi$. There is a cluster of values in the $-4 \Phi$ to $-6 \Phi$ range which are very well sorted. There are also two groupings of finer sediment samples in the $1 \Phi$ to $2 \Phi$ range. These represent the northern and central Days Bay sites and the dune sand components of the Rona Bay samples. Overall, grain size and sorting is shown to be highly variable through all samples along and across shore. 


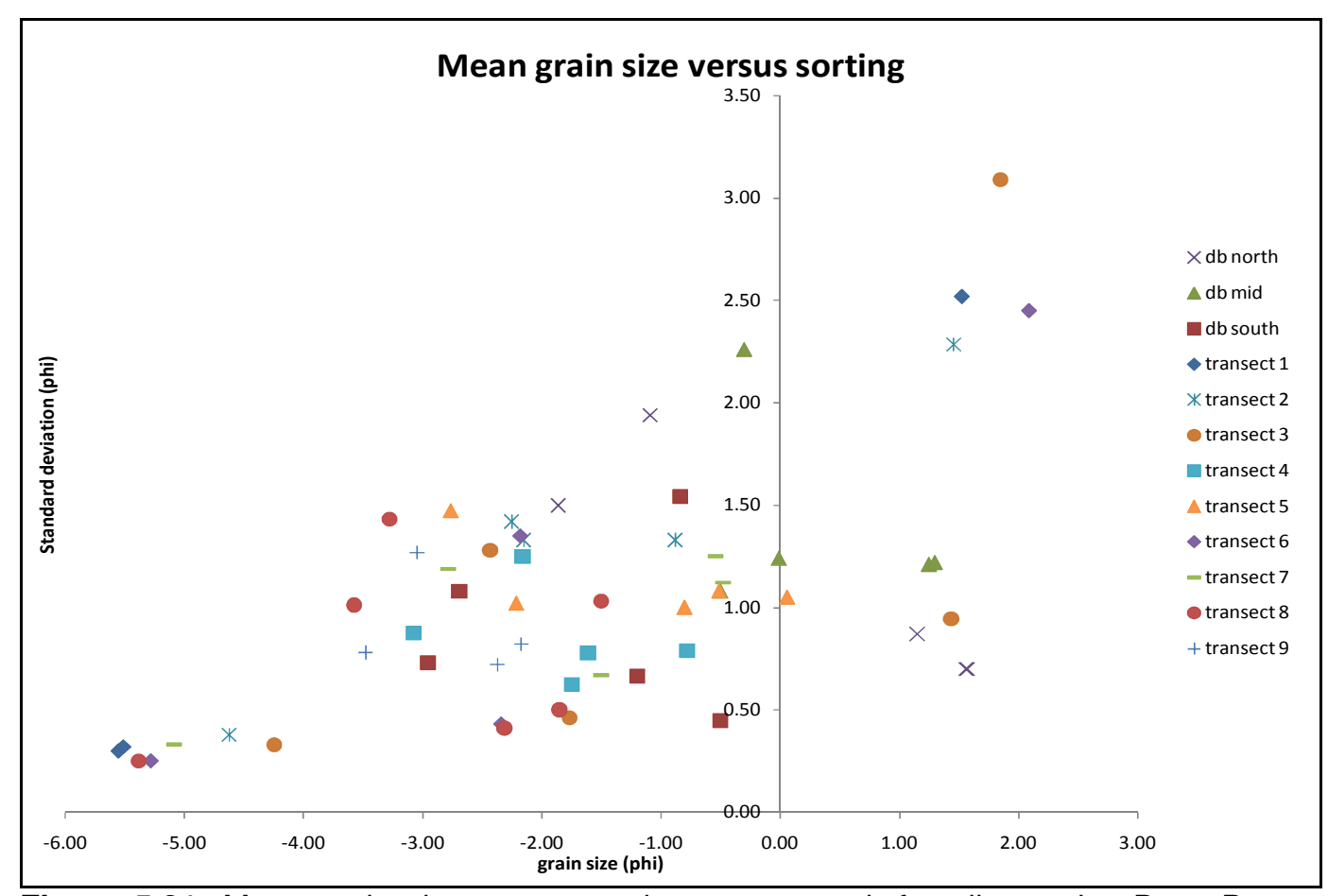

Figure 5.21: Mean grain size versus sorting scattergraph for all samples Days Bay to Point Arthur.

A clearer longshore grading trend is evident when comparing proportions of sand and gravel at each site. The samples taken from north of the sea wall show a greater proportion of fines than those further south. Fines in the southern transects 7 to 9 are restricted to the swash zone and back beach areas are almost exclusively gravel (Fig. 5.22). 


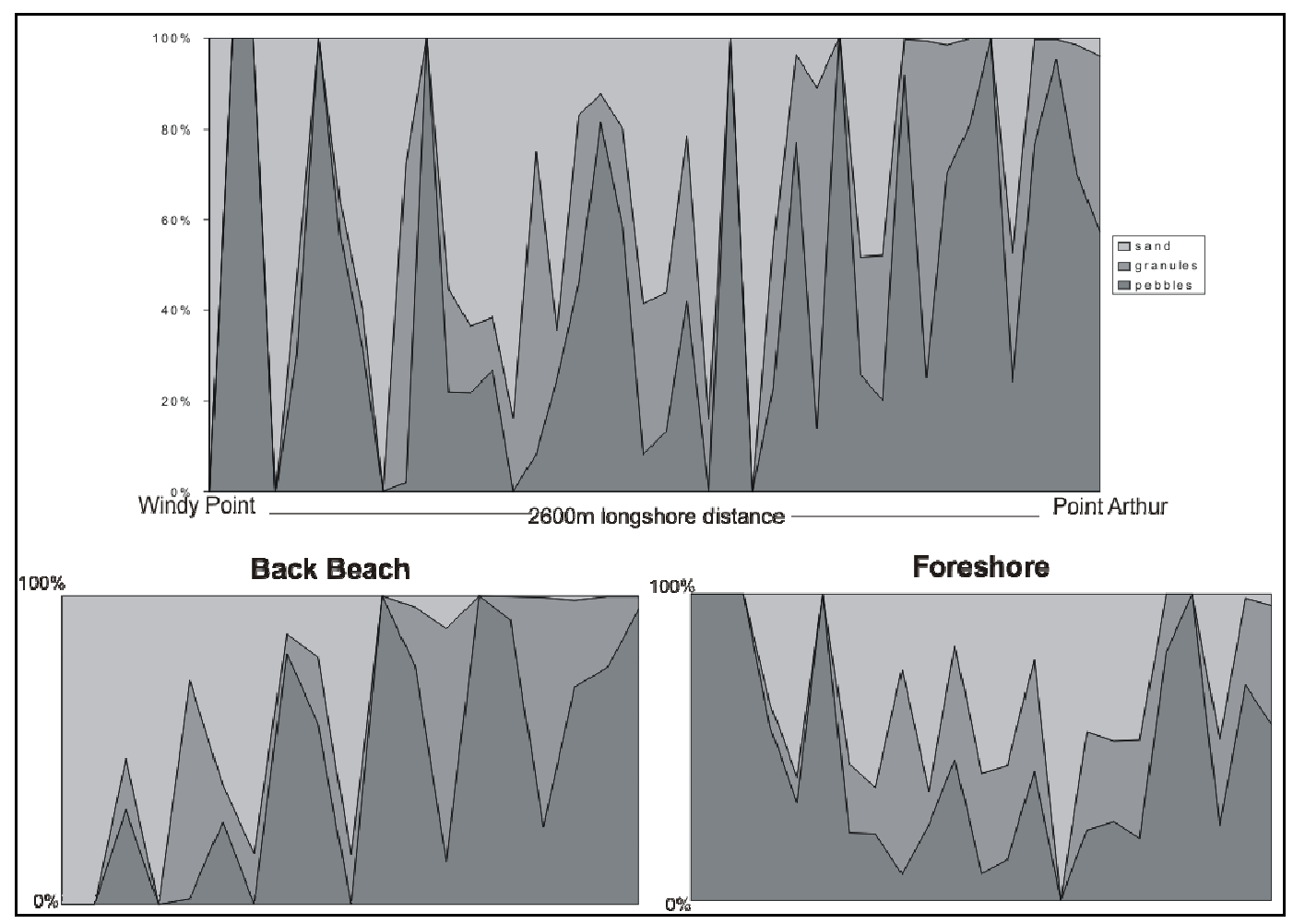

Figure 5.22: Percentage of sand, granules and pebbles for all Eastbourne samples between Windy Point and Point Arthur (top), and separated into backbeach (bottom left) and foreshore (bottom right) zones.

Overall, the grain size analysis has suggested that grain size distribution through central Eastbourne is highly spatially variable as would be expected from a mixed sand and gravel beach system 


\section{Chapter Six: Discussion}

\subsection{Introduction}

The Eastbourne coastline is an active mixed sand and gravel beach system operating within a fetch-limited harbour environment. It marks the northern extent of a littoral drift system that extends $20 \mathrm{~km}$ southward, through the Wellington Harbour and onto the open-ocean coast. Eastbourne's beaches are dynamic on annual and decadal timescales, with short term fluctuations in fair weather and storm profiles superimposed on longer-term processes of shoreline advance. This shoreline advance is the subject of the following discussion, which details: (1) the impact of the gravel front described in the previous chapter on the study site at Robinson Bay and the wider coastline, (2) the processes driving the observed spatial and temporal variations of the study area, (3) a conceptual model of beach evolution for the area, and (4) the implications of the observed coastal changes on future shoreline stability.

\subsection{Observed morphological adjustment of the coastline}

Results presented in the previous chapter indicate that the Eastbourne/Pencarrow coast has undergone a long term pattern of coastal progradation, with smaller scale periodic erosion/accretion cycles. This section briefly discusses our understanding of the morphological adjustments of the coastline based on these results. Additionally, to add context to our findings, they have been compared and contrasted with previous research on the shoreline stability of this area. This past research includes key papers describing the sediment dynamics and beach morphology of Pencarrow and Eastbourne. These include Carter (1977), Matthews (1980a,b, 1982), Carter and Gibb, (1985) and Hastie (1989). At the time of these studies the gravel front had yet to impact central Eastbourne and the northern bays; currently it extends are far north as Days Bay. The historical development of the study area to its current geomorphology is summarised below in three phases of development: (1) 
1855 to 1941 , (2) 1941 to 1985 , and (3) 1985 to present. The focus of this will be Robinson Bay, as the morphological development of this embayment is most pertinent to this thesis.

\section{Phase 1: 1855 to 1941}

The current coastal regime was initiated by $2.1-2.7 \mathrm{~m}$ of instantaneous uplift from the 1855 Wairarapa Earthquake (Matthews, 1980a,b), the effects of which will be discussed later on in this chapter. Following this uplift event, Robinson Bay experienced $\sim 80 \mathrm{~m}$ of shoreline advance between 1863 and the early 1920s relating to an initial pulse of sand supplied by longshore drift from the south (Gibb, 2005). From the early 1900s this shoreline advance was interrupted with erosion events, intensifying from the 1920s onwards. In response to these erosion events, a sea wall was constructed in the early 1900s (Matthews, 1980a), which failed between 1934-36 in the face of two southerly storm events (Gibb, 2005).

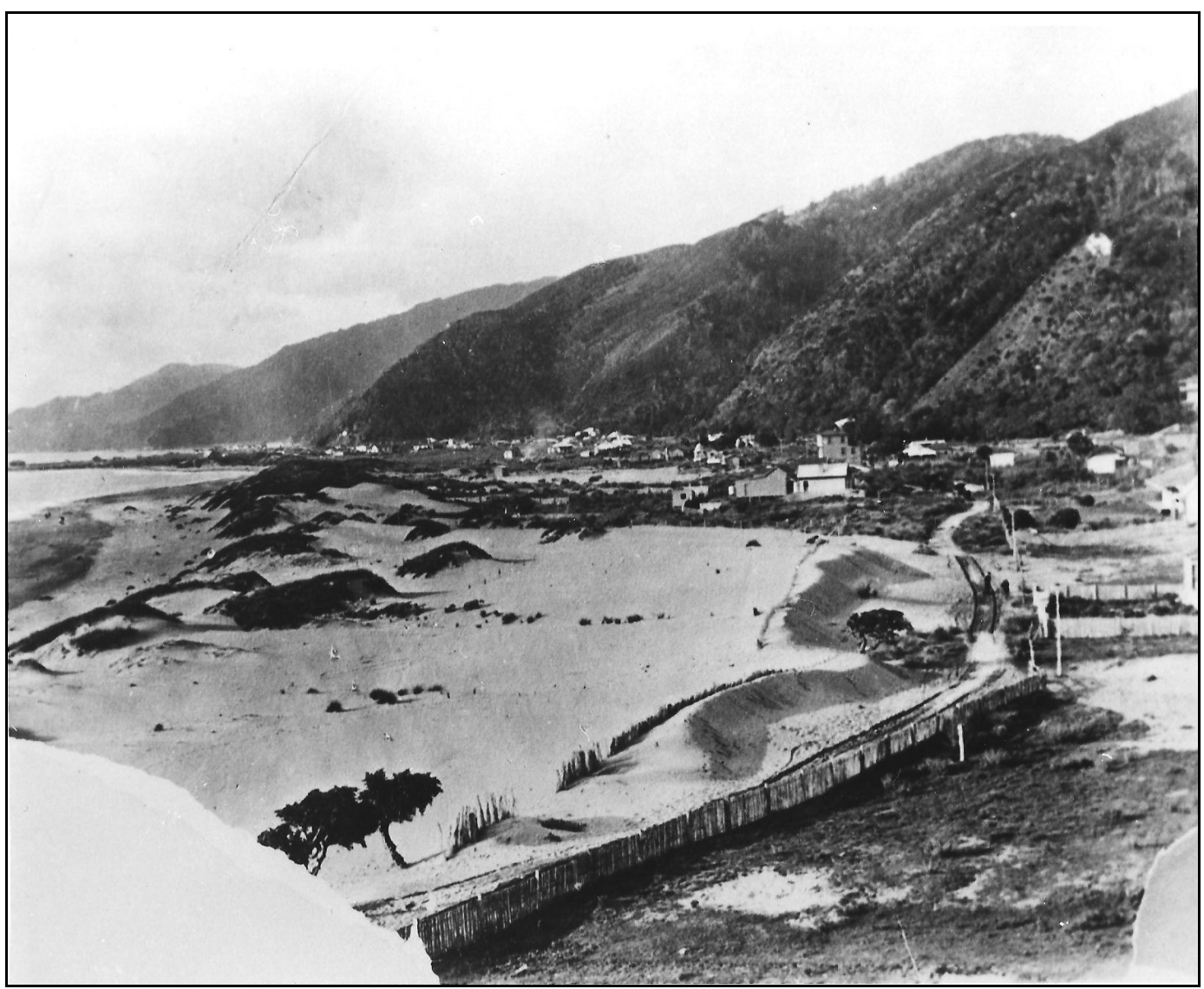




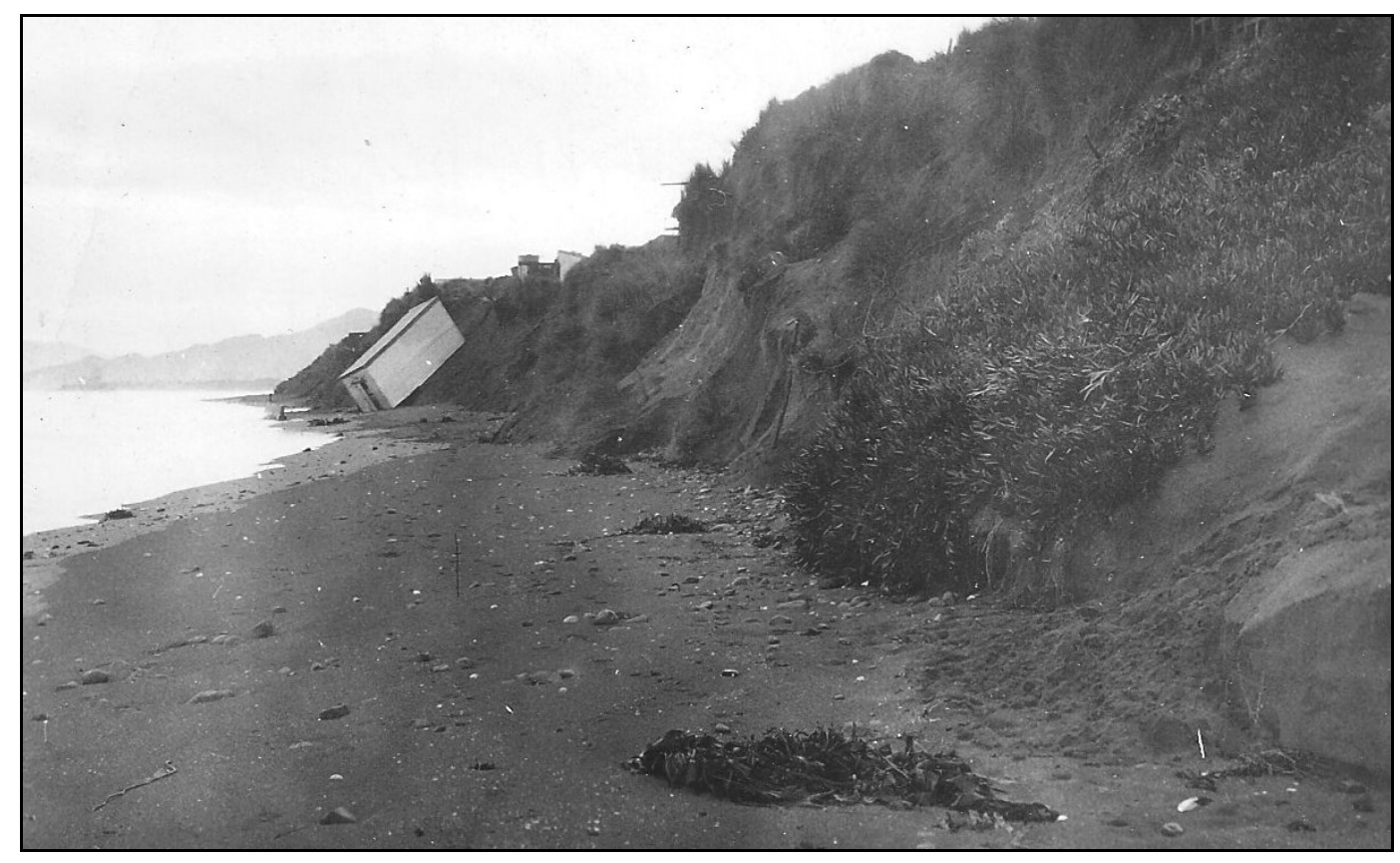

Figures 6.1 and 6.2: Fig. 6.1 depicts Robinson Bay in 1902 looking north, showing an extensive sandy system with undeveloped dune field (Source unknown. Courtesy of Eastbourne Historical Society). Fig. 6.2 shows Boyd-Wilson's Garage at south end of Puketea Street after extensive erosion, Looking north, 1936 (Orchiston, R. Courtesy of Eastbourne Historical Society).

\section{Phase 2: 1941 to 1985}

Between 1941 and 1969, 30\% of Robinson Bay beach was retreating at rates of up to $0.5 \mathrm{~m} / \mathrm{yr}$. Results from Chapter Five indicate that the remaining $70 \%$ of the beach was advancing at 0.05 to $1 \mathrm{~m} / \mathrm{yr}$. Between 1969 and 1985 50-60\% of the shoreline at Robinson Bay was retreating by 0.5 to $1.5 \mathrm{~m} / \mathrm{yr}$, with the remaining areas accreting at rates of up to $1.2 \mathrm{~m} / \mathrm{yr}$. This increase in erosion marked the end of the initial sand pulse following and caused by the uplift associated with the 1855 earthquake event. In response to continued damaging episodic erosion in 1944, 1949 and 1950, a more robust concrete sea wall was constructed in 1956-57. Following the completion of this sea wall, Matthews (1980b) suggests that sediment losses in the southern reaches of Robinson Bay were minimal. The sea wall however had the unintentional effect of shifting the erosion problem to the northern part of Robinson Bay. During the 1960s and 1970s there was a period of increased storminess through the study area including Cyclone Giselle in 1968, which caused significant coastal erosion. In response to this, a boulder rip-rap was constructed adjacent to 
the H.W. Shortt Recreation Grounds. The beach at Robinson Bay was operating as a sandy beach system at this time, as the gravel front now present at this site had only reached Camp Bay to the south (Fig. 6.3) prior to 1985.

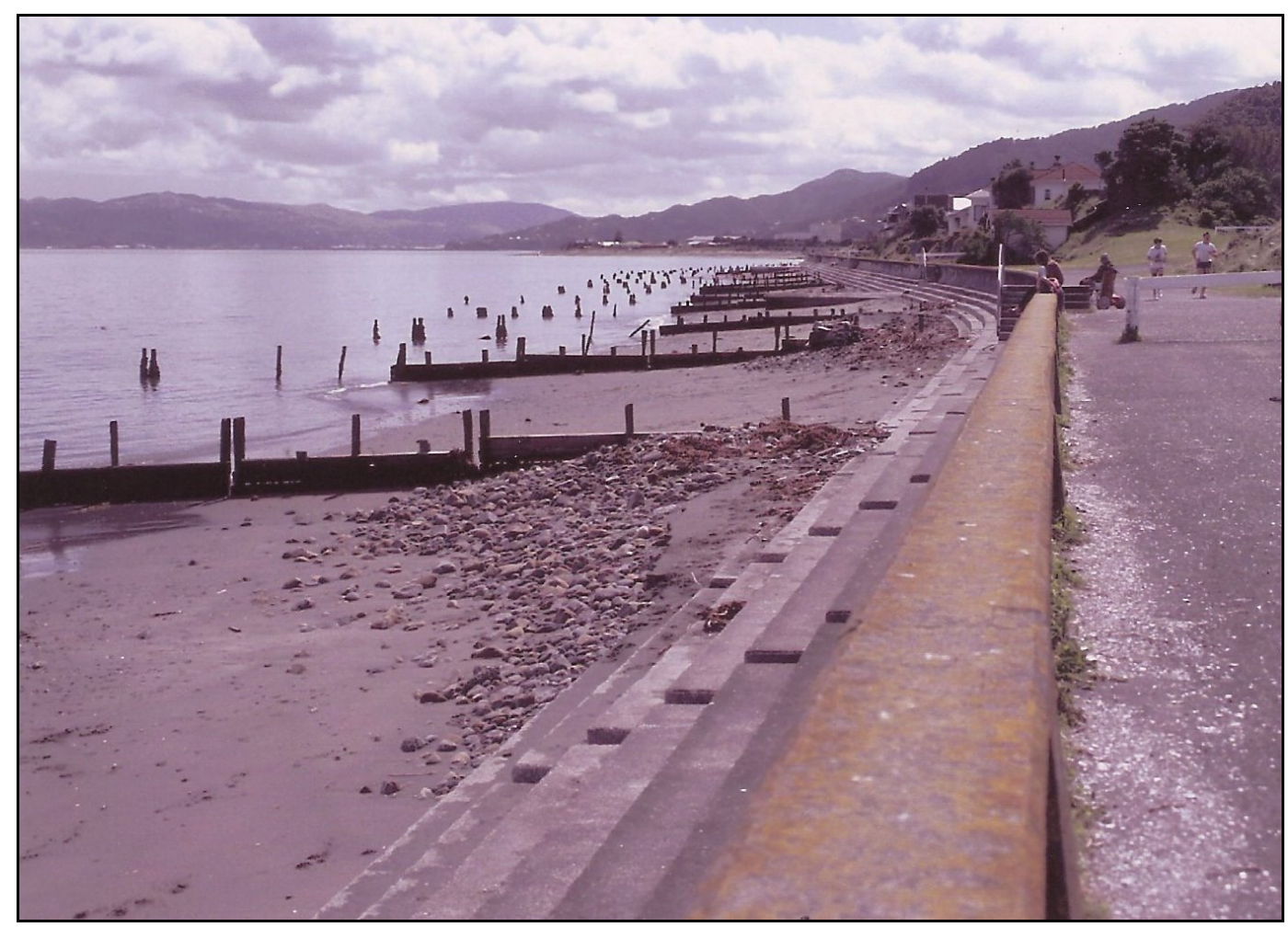

Figure 6.3: Robinson Bay, 1984 looking north showing the sea-wall and groyne system. The beach is still sandy and erosional however, pockets of gravel are starting to form on the updrift side of the groynes (Courtesy of Malcom Burden Collection).

\section{Phase 3: 1985 to Present}

1985 marked a significant change to the sedimentation of Robinson Bay, as the gravel front began to encroach on this section of the coastline. The gravel front has now extended northward of Robinson Bay through Rona Bay and into Days Bay, changing beach volumes and morphology significantly. Between 1985 and 2008, the arrival of the gravel front has caused between 20 to $100 \mathrm{~m}$ of progradation at rates of up to $4 \mathrm{~m} / \mathrm{yr}$. Past studies had associated this progradation with a pulse of sediment directly sourced from earthquake triggered landsliding form the 1855 Wairarapa Earthquake, that had taken $150 \mathrm{yr}$ to migrate around from the Orongorongo River. The results of this study suggest that rather than a 
short term pulse of material, the changes at Robinson Bay relate to an overall change in the sediment supply, which is discussed in the following section.

\subsection{Evidence of permanent change on the Eastbourne coastline}

Chapter Five has indicated significant net accretion, averaging 20 to $100 \mathrm{~m}$ has occurred throughout more than $90 \%$ of the embayed coast of Eastbourne between Burdans Gate and northern Days Bay from 1941 to 2008. The $10 \%$ of the coastline where net shoreline retreat observed is predominantly located in Days Bay where the gravel front is only now establishing, and in pockets of Robinson Bay. The minor occurrences of net shoreline retreat in Robinson Bay can be attributed to sediment transport dynamics driven by local variables such as periodic increases in storminess, as well as anthropogenic development. This includes the effects of coastal modification for residential development and subsequent erosion mitigation efforts. In particular, the effects of the sea wall at Robinson Bay provide a landward barrier to natural beach feedback loops.

The current trend towards shoreline accretion in central Eastbourne has raised questions about whether the change in sediment supply is a temporary 'pulse' caused by increased coarse sediment eroded from the Orongorongo and Wainuiomata catchments during the 1855 earthquake (Matthews, 1980a,b); or whether the observed effects are the result of a more permanent change to the system. If this was a single episode, it would be expected that an initial rise in sediment supply would peak and subsequently decrease back toward an equilibrium state similar to that observed prior to the pulse. If the progradation at Eastbourne is indeed related to a pulse, the falling limb of the pulse is operating significantly slower than its initial rise, at a rate slow enough to maintain shoreline stability through the southern extent of the littoral cell for over 40 years.

To determine the temporal scale of the current progradation episode, it is necessary to further discuss the temporal beach width results presented in 
Chapter Five. This involves an assessment of the changes at the main study site in Robinson Bay, with reference to the wider study area extending to the Orongorongo River. Aerial photo analysis has not provided any significant evidence for shoreline retreat through Pencarrow between 1941 and 2008. This is especially emphasised when beach widths from sites closer to the sediment source are temporally analysed, as they would be the most probable sites to begin to show retreat following the pulse theory. Figure 6.4 Shows that beach width has not decreased through Pencarrow Bay between 1941 and 2008. Rather, a significant increase in beach width (10-40m) was observed over the 34 years between 1941-75. Thereafter, beach width remained constant (+/$5 \mathrm{~m}$ ) over the 33 years to 2008 . This is further supported by the fact that Kohingapiripiri Bay, Camp Bay and much of the coastline up to Burdans Gate have shown constant width since the arrival of the gravel front.

As previously mentioned, gravel beaches are erosive by nature (Kirk, 1980) and progradation of such a system implies the sediment source is large enough to both replace the eroded material as well as supply enough material to cause progradation. In the $>20 \mathrm{~km}$ length of the Eastbourne coastline, the observed beach width has increased and been sustained over the past 67 years. It has been estimated that gravel is continually removed from the active beachface through attrition at rates of $2,300-5,500 \mathrm{~m}^{3} / \mathrm{yr}$ (Matthews, 1982). This equates to a total volume of $351,900-841,500 \mathrm{~m}^{3}$ for the 153 years between the 1855 uplift event and the 2008 aerial photo set used in the temporal analyses. Despite these substantial losses in sediment from the system, beach volumes have remained high throughout decadal temporal scales, with the current volume of Rona-Robinson Bay beaches estimated to be $\sim 200,000 \mathrm{~m}^{3}$ from the survey results for this project.

The net shoreline advance and sustained high beach volumes seen in the study area suggest that the shoreline has been adjusting to sustained changes to the sediment supply regime. In addition to this shoreline accretion, continual northern migration of the gravel front has been 
observed over the current decade and the northern extent of the front is now located in Days Bay. This continued northward migration in combination with beach accretion provides further evidence for a long term change to the sediment supply regime, which has altered beach morphology and volume as seen in the survey results of this study.

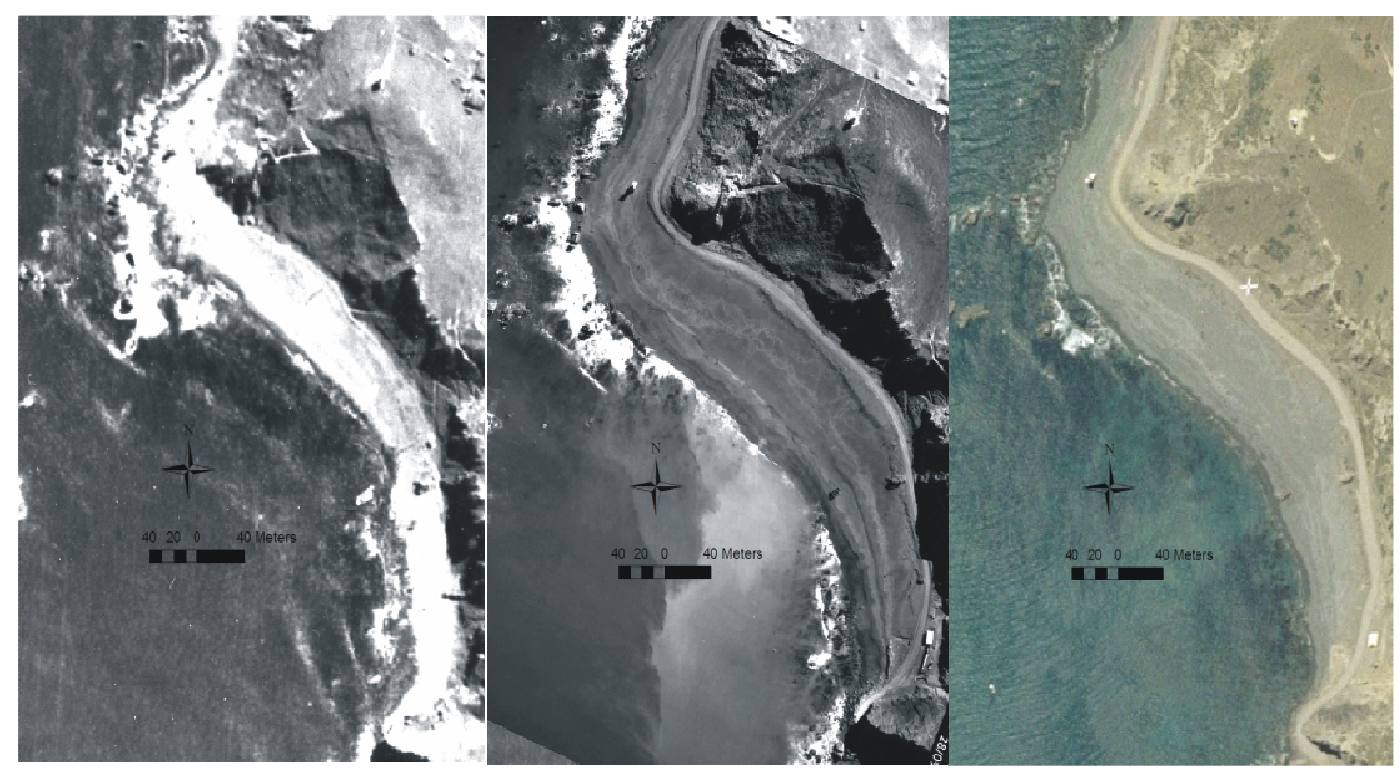

Figure 6.4: Aerial photos of Pencarrow Bay in 1941, 1975 and 2008 (left to right) showing the initial shoreline accretion as the gravel front passes through the embayment infilling it between 1941-75 and then maintaining this width up to 2008 .

\subsection{Drivers of coastal change in Eastbourne}

Additional to the change in sediment supply described above, there are two key factors that can drive the changes seen in the study region. These are tectonic uplift and longshore sediment transport processes. Their relative roles in the study area will now be discussed.

\subsubsection{Tectonic uplift and shoreline advance}

The initial triggering process behind the current coastal regime was the 1855 Wairarapa Earthquake, resulting in $\sim 2.1 \mathrm{~m}$ of uplift resulting in changes in sediment supply and associated rapid progradation of Eastbourne's shoreline (Matthews, 1980a, Gibb, 2005). This uplift would have had three significant effects on the coastline of the study area: 
1. The river-sourced sediment regime would have changed significantly. Earthquake-induced landsliding and base level change would have led to the aggradation of the lower Orongorongo catchment, which will be continually adjusting to these effects. This increased supply is being redistributed onto the continental shelf by subsequent periodic rainfall events, not as a distinct pulse of sediment (Hastie, 1989).

2. Uplift would also have removed sediment from the nearshore zone, Stranding gravel sized material in the form of uplifted beach ridges and creating an undernourished beach system (Matthews, 1980a,b). Backscatter and sidescan sonar images of the nearshore (Pallentin et al., 2009; Carter and Mitchell, 1988) show a large amount of sand on the harbour floor. This may have initially fined up the beaches and now they are reverting to their natural state and aggrading into gravel.

3. The rocky headlands would have uplifted and extended seaward creating a series of empty compartments or pocket beaches and enlarging many of the existing embayments. This has created accommodation space for the accumulation of the gravel front migrating northward along the coastline.

These three changes have created a coastal environment conducive to progradation by creating a perturbation to the normal littoral drift system. This system has to now adjust back toward an equilibrium state. Though the catalyst for the observed change, it may be assumed that given the estimated 500 year return period for such an event, tectonic uplift will not play an ongoing role in the morphological changes observed in the study site. This means, once the earthquake set the boundary conditions of shore depth and the location of rocky points, contemporary processes such as waves and tides then dominate landform evolution. 


\subsubsection{Longshore sediment transport processes}

At present, the main driver feeding the coastal system and the cause for ongoing morphological and sedimentological change is longshore drift from the south (Matthews, 1980a,b). Sediment sourced from the Orongorongo River is being transported sub-tidally by wave and tidal currents, and subaerially through the swash zone. This section will account for the factors which influence longshore sediment transport in this area.

As aforementioned, southerly swell waves are the main contributors to longshore drift in the study area. Wave height and wave power from southerly swell waves is reduced significantly with distance into the harbour through refraction in the form of shoaling on the sea floor and topographic blocking from headlands. For example, for a nine second period southerly swell wave, there is a marked decrease in significant wave height with distance north into the harbour, from 2.16m at Camp Bay in Pencarrow (Fig. 6.5) to $0.65 \mathrm{~m}$ at Rona Bay $5 \mathrm{~km}$ to the north. This equates to an a $0.3 \mathrm{~m}$ wave height reduction per kilometre, however this rate is not constant, with height fluctuating through Robinson Bay There is a notable convergence of orthogonals at the main study site at northern Robinson Bay, where wave height increases to $1.76 \mathrm{~m}$ from $0.93 \mathrm{~m}$ further south in the middle of the Bay, corresponding with the northern end of the sea wall. Point Webb (between Rona and Robinson Bays) appears to be the threshold where the dominance of the southerly swell wave energy gives way to conditions dominated by southerly generated wind waves, but this point will vary during high swell storm events where swell waves will still impact the northern bays. 


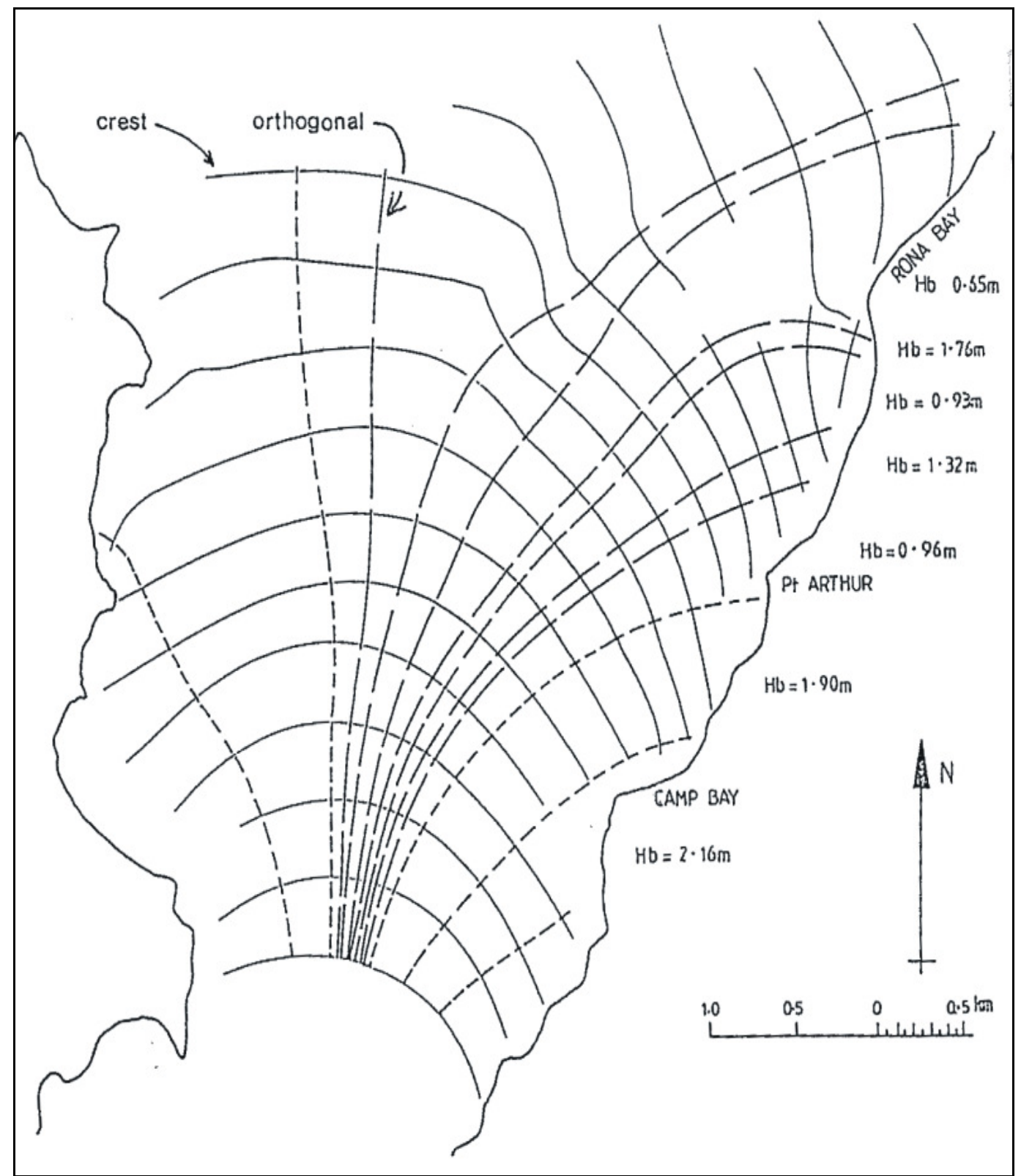

Figure 6.5: Wave refraction diagram for East Wellington Harbour for 9s period swell wave, showing reduction of significant wave height from $2.16 \mathrm{~m}$ at Camp Bay to $0.65 \mathrm{~m}$ at Rona Bay (Hastie, 1989:10).

The physical controls which may influence longshore drift generally come in the form of topographic features, and can work to either impede or assist longshore transport. These include headlands, artificial groynes, islands and marked changes in bathymetry. In Eastbourne this is represented as the headland-embayment dominated coastline and the broad shallow Eastbourne Platform. Additional to showing the features discussed above, a backscatter image from Pallentin et al. (2009) indicates the extent of the gravel front on the Eastbourne Platform. It 
shows bands of coarse sediment running diagonally interposed with exposures of bedrock, which provide a surface for the gravels to move on, rather than being buried in the sands. Figure 6.6 shows the location of the Eastbourne Platform and Ward Island. This broad platform reduces wave energy through shoaling, contributing to the northward reduction of wave heights (as seen in Figure 6.5) and subsequent sediment transport potential. Also, the shallowness of the platform allows bottom currents from wave shoaling to interact and initiate shoreward directed transport. This platform attenuates the swell energy entering the Harbour and creates the energy gradient from south to north. Additionally, rocky headlands and beach orientation have the ability to influence longshore drift through the mechanism of topographic blocking. This causes a reduction in the speed of northward movement of the gravel because these topographic features promote gravel deposition and infilling of embayments punctuated by them. 


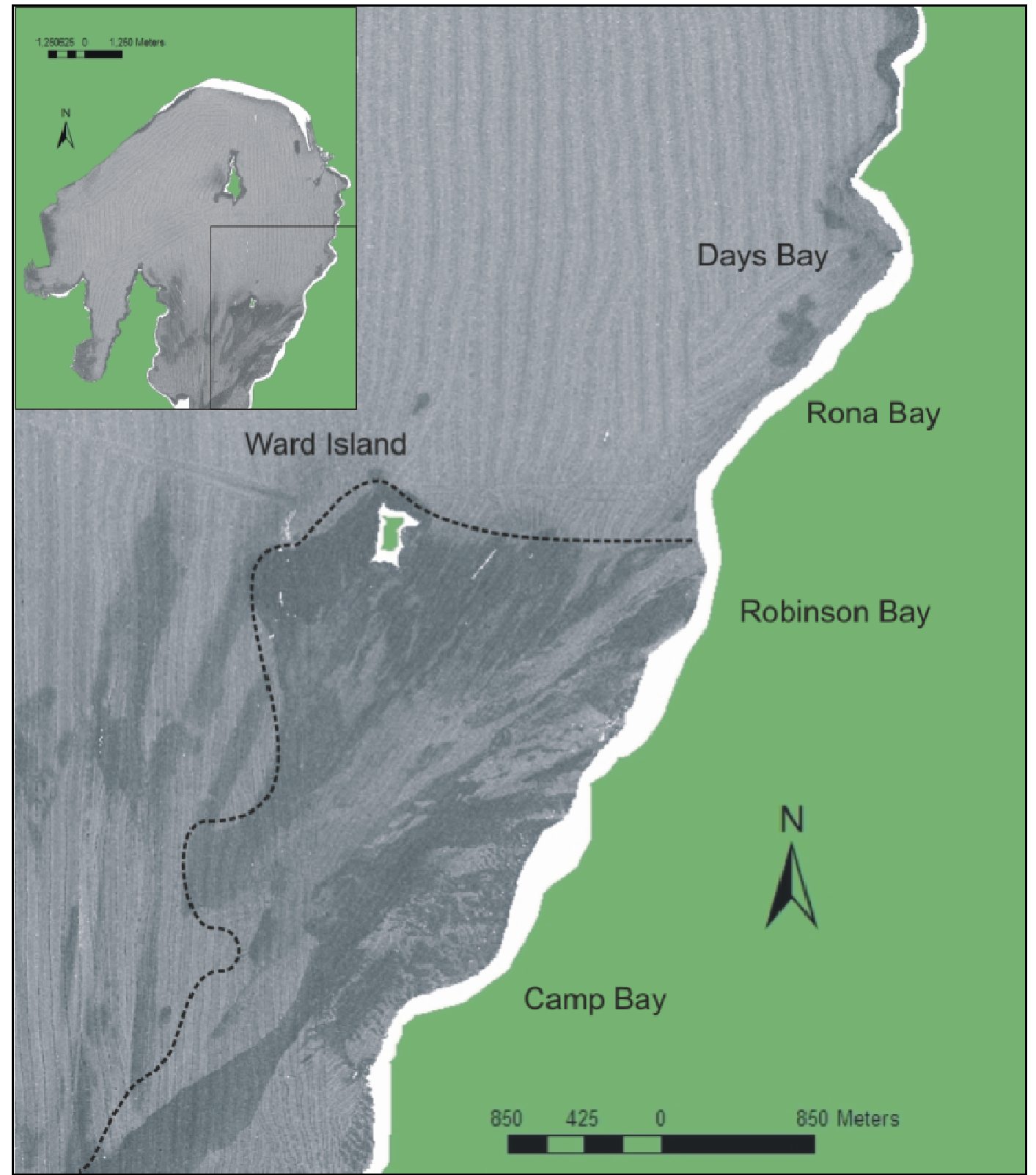

Figure 6.6: Sun-illuminated Backscatter image of the Eastbourne Platform and Wellington Harbour (inset). The dark grey patches indicate coarser sediment, which appears to be primarily restricted to the Eastbourne platform and in patches through the western side of the harbour entrance (Pallentin et al., 2009).

\subsection{Interpretation of rates of transport 1855 to 2008}

The rate at which the gravel front has been transported through the littoral cell was calculated to be $114 \mathrm{~m} / \mathrm{yr}$ between 1855 and $1941,100 \mathrm{~m} / \mathrm{yr}$ between 1941 and 1975, 260m per year between 1975 and 1985 and $200 \mathrm{~m} / \mathrm{yr}$ between 1985 and 2008. This indicates that the transport rate has increased through the northern part of the littoral cell which seems counterintuitive given that wave height and energy is decreasing with 
distance north. The calculated transport rates from this project have been compared to wave refraction patterns for this stretch of coast (Matthews, 1980b). Matthews (1980b) has calculated the longshore components of wave power between Turakirae Head and Hinds Point (Fig. 6.7). These values are variable between neighbouring embayments based on beach orientation and wave approach, but decrease overall with distance north. The discrepancy between the calculated transport rates and the longshore wave energy components given by Matthews as the primary controls of transport rates suggests that an additional factor has influenced the gravel migration rates.

This discrepancy can be reconciled by considering embayment planform morphology. South of Pencarrow Head, the embayments are larger and are swash orientated. North of Pencarrow Head, the coastline is more sinuous and embayments are smaller with extensive headland outcrops, increasing roughness. Though the southern-most bays have high potential for longshore transport, they also have more accommodation space for the accumulation of gravel. Therefore the front would not have been able to bypass and transport rates would have been low while the front initially moved through, despite high longshore transport potential. Further north, wave energy decreases, but the coastline orientation should promote longshore drift. However, the rates through from Pencarrow Bay to Hinds Point (1941-1975) have been the lowest observed (Fig. 6.7). This is because of the high proportion of headlands and embayments that the front would have to infill and bypass. This would cause a reduction in the speed of the northward propagation of the gravel front.

The northern-most stretch of coastline between Hinds Point and Days Bay (Fig. 6.7) has experienced the highest observed transport rates. There are three reasons for this. Firstly, the rapid rates between 1975 and 1985 would have been significantly influenced by an increased storm frequency. This increased storminess had two effects - accelerated erosion in the northern part of the cell, and rapid rates of translational movement leading to deposition in the southern embayments. Post-1985, increased rates 
cannot be accounted for by increased storminess. However, high transport rates have been maintained by the ability of sediment to efficiently bypass the now in-filled southern section of the littoral cell. Finally, the coastline between Camp Bay and Days Bay is a smoother section of the coastline with fewer obstacles to northward sediment transport.

The interplay between these processes is represented schematically in Figure 6.8. This shows wave energy to be reducing with distance north, caused by wave refraction. The second schematic representation shows relative coastal roughness in the study area, and the third shows longshore drift rate as suggested by the results of this study. The figure illustrates how wave power is decreasing at a constant rate, while roughness increases into the middle section of the drift cell (near Hinds Point). The drift rate initially decreases as a function of decreasing wave power and increasing roughness. As roughness decreases into the northern part of the cell (Camp Bay to Robinson Bay), drift rates increase again until a threshold is reached where wave energy is so reduced that high drift cannot be sustained. This threshold is likely to be at Point Webb, as discussed in Section 6.4.2. However, longshore drift will continue through the cell at reduced rates as evidenced by the recent accumulation of gravels in southern Days Bay. As with Robinson and Rona Bays, it is hypothesised that this embayment will continue to infill with gravel, causing a change from an erosional to a depositional regime. 


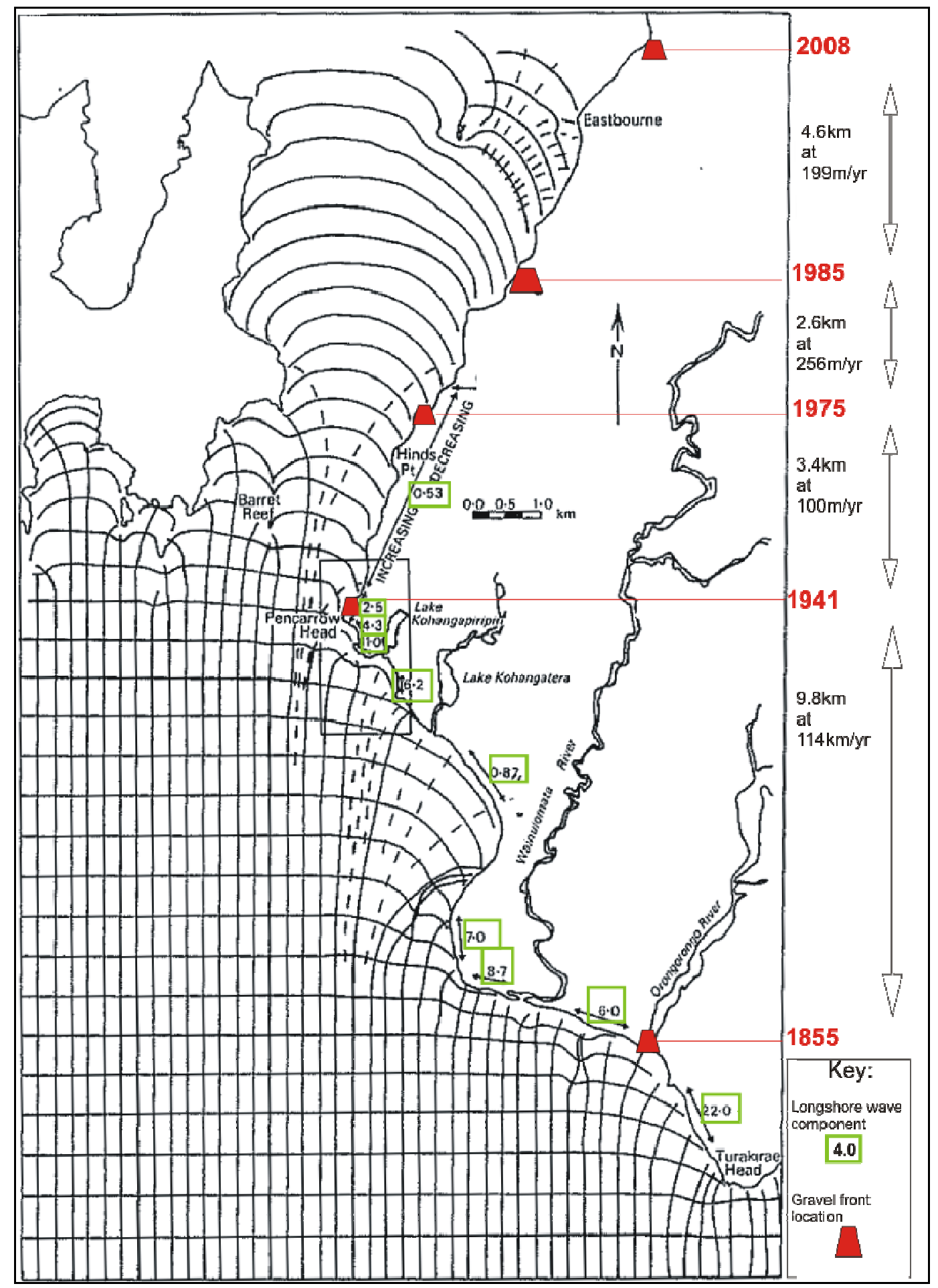

Figure 6.7: Wave refraction diagram for Turakirae Head to Eastbourne for a $9 \mathrm{~s}$ period southerly swell wave with the longshore components of wave energy from Matthews (1980b) (green boxes), and the locations of the gravel front (in red) showing distances . This diagram shows an overall reduction of the longshore component of wave energy with distance into the harbour, with variation relative to beach variation (based on a figure from Matthew, 1980). 

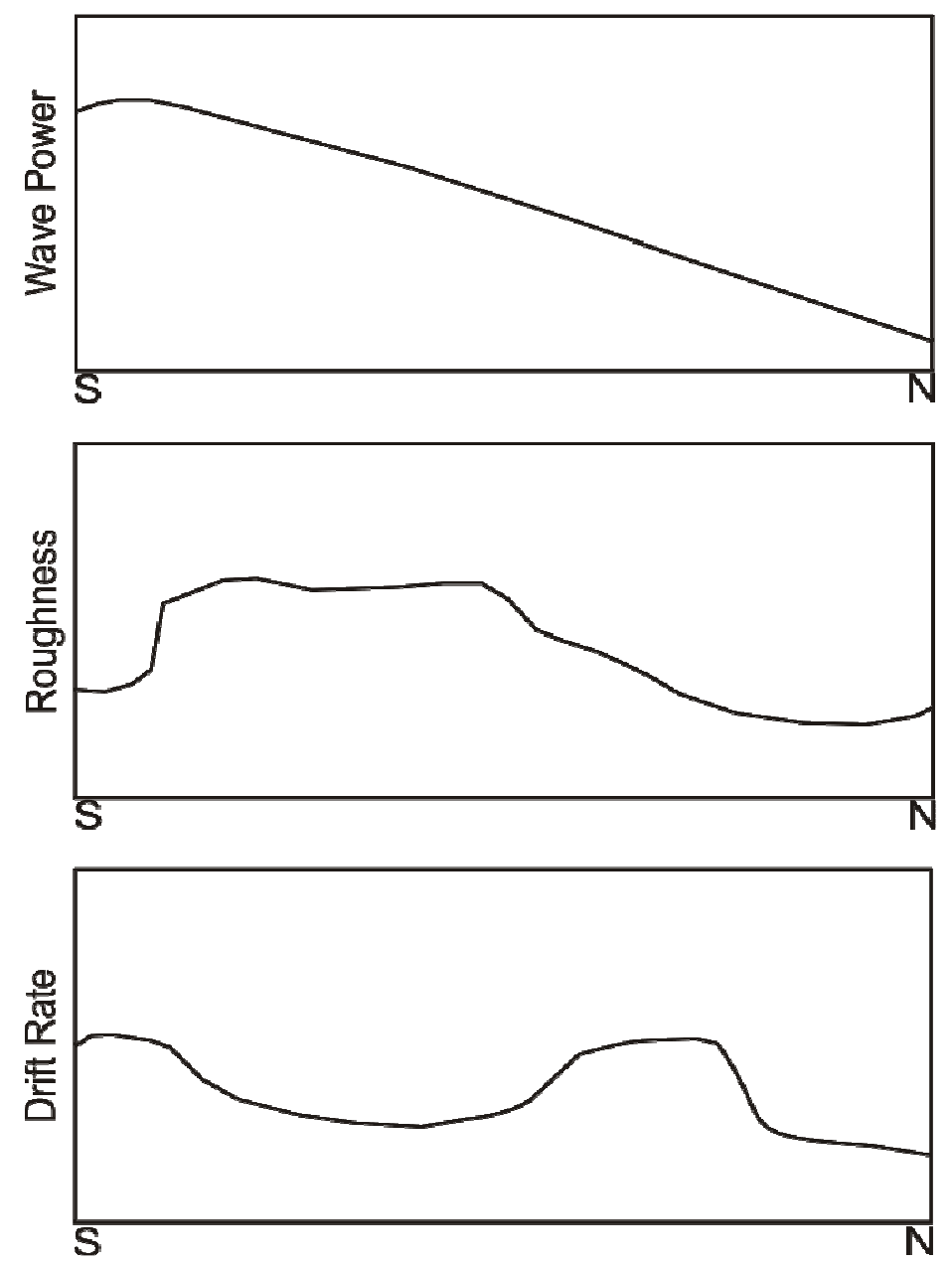

Figure 6.8: schematic diagram representing spatial variations in wave-power, roughness and drift rate for the Eastbourne-Pencarrow littoral cell. The effects of these variables are discussed in the text.

\subsection{Beach evolution model}

The interpretation given in section 6.5 has suggested that the migration of the gravel front, in addition to being dependent on continual supply of material and transport mechanisms, is effected by coastal roughness caused by rocky headlands. The interplay between these parameters has been incorporated into a model of beach evolution for this study site (Fig. $6.9)$.

The beach evolution model for the study site is summarised below. It is built using the documented history of shoreline change integrated with an improved understanding of ongoing physical processes obtained from this study. This model covers beach evolution for both longshore and cross 
components of beach morphology for the Eastbourne-Pencarrow coastline.

\subsubsection{Longshore change}

As the gravel is transported north, the Pencarrow embayments have acted as gravel traps slowing transport rates as material has accumulated in each embayment. This accumulation is thought to occur mainly as small 'slugs' of gravel migrating around the headlands in response to swell events (Matthews, 1980b). This persists until a threshold is reached where the bay is no longer an effective sediment trap, and material is able to bypass an embayment and begin accumulating in the next downdrift embayment. This beach evolution model is represented in Figure 6.9. where the initial beach state is an undernourished system with either exposed bedrock as seen in the Pencarrow beaches in the southern reaches of the drift cell, or sandy and narrow as seen through the Robinson Bay and Rona Bay up to 1985 (Fig. 6.9, stage 1). As longshore drift moves the gravel into each embayment, variation in uprush and backswash wave power and wave angle in the swash zone allows material to be deposited on the upper foreshore, increasing beach volume and altering morphology (Fig. 6.9, stage 2). Continual longshore supply allows the beach to prograde to a peak width where the embayment is no longer an effective sediment trap, and material can migrate past the northern headland and into the next embayment (Fig. 6.9, Stages 3 and 4).

It is worth noting that smaller scale within-embayment changes will affect this evolution model. Research into longshore sediment transport on MSG beaches has shown that gravel is efficiently transported by wind waves within the swash zone, and these waves will be highly variable in height and angle through both time and space (Dawe, 2006). This means there can also be variation in transport rates and patterns operating on smaller scales within individual bays. Therefore transport rates can increase or decrease depending on the position of the material in the embayment, 
where gravel may be transported quickly through the more transport aligned middle sections of a bay towards the northern reaches. At which stage the shoreline orientates more toward the prevailing conditions and the swash zone/foreshore becomes dominated by shore normal exchanges as the beach becomes more swash aligned. This has the effect of slowing the northward moving gravel front. But over time, the bay fills up and gravel slowly leaks around to the next bay, whereupon it is picked up again by obliquely breaking southerly wind waves and the process continues. Once this process has been repeated for southern bays sediments can efficiently and quickly bypass extensive sections of coast to be deposited in the northern bays.

Once all the embayments in a given section of the coastline are in-filled, the roughness discussed in Section 6.5 is reduced for that stretch of coastline. This smoothing effect promotes more efficient sediment bypassing through the entire section of the coastline and increases longshore transport rates. 

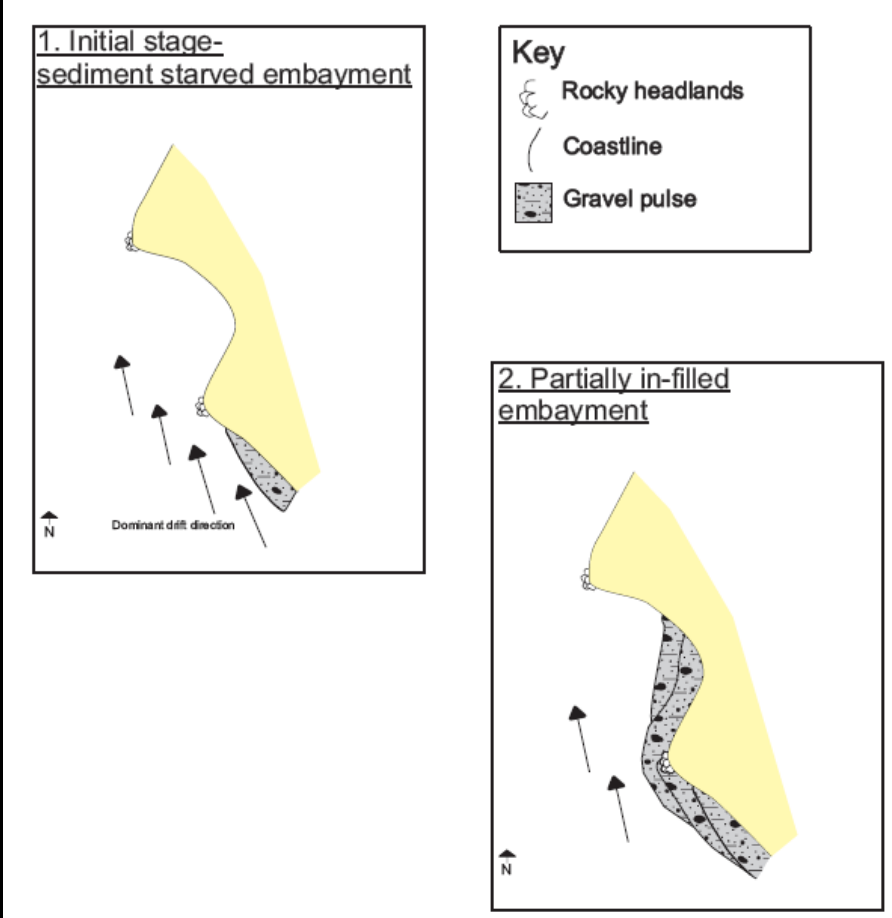

3. In-filled embayment

5. Sediment bypass and possible scouring of Southern extent
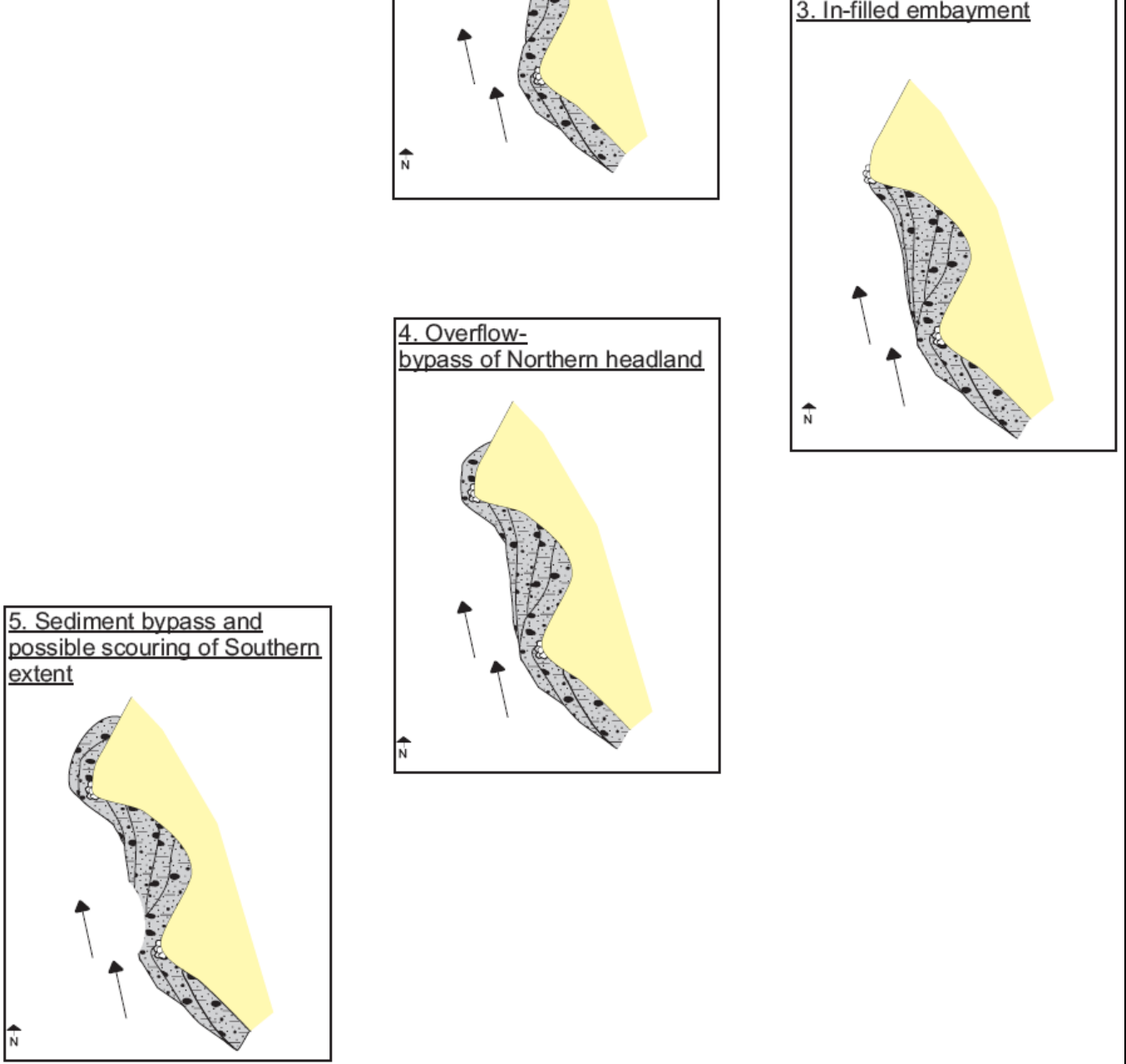

Figure 6.9: Schematic diagram of planform beach evolution through Eastbourne and Pencarrow as gravel front migrates northward under the current longshore sediment transport regime. Stages 1 to 5 show the impact of the gravel as it enters an embayment, increasing volume and changing planform morphology to a threshold, and then is able to bypass the northern headland and begin the process again in the next bay downdrift. 


\subsubsection{Cross-shore change}

This longshore evolution has the effect of altering cross-shore morphology as seen in the survey results presented in chapter five. The profiles surveyed through Rona and Robinson Bay maintain a similar a similar morphology to the MSG beach model presented by Kirk (1980), with the main difference being beach width and the absence of backbeach areas with coarse, discoid-shape clasts. The Eastbourne and Pencarrow beach widths are generally $<100 \mathrm{~m}$, whereas Kirk (1980) has stated that MSG beach width is typically $100-200 \mathrm{~m}$. The reasons for these variations from Kirk's (1980) model are that the study area is a fetch limited environment and is therefore a lower energy system than those open ocean beaches discussed by Kirk. Additionally, the littoral system still is establishing and has not reached equilibrium as the northern sections of the coastline are in transition from sandy to MSG system, particularly at Days and Rona bays.

The cross-shore morphology of the beaches within the study site changes with the change in sediment supply. Figure 6.9 is a generalised model of cross-sectional beach evolution as seen in the larger embayments through Pencarrow, and also through parts of Robinson Bay. It is a midembayment model and is not necessarily representative of all parts of the shoreline. The initial stage described shows a narrower sandy beach as seen in Robinson Bay prior to 1985 with a more gradually sloped foreshore and weakly developed tidal/storm berms (Fig. 6.10, initial profile). As the gravel front begins to move through the embayment there is an increase in volume with more distinct storm and high tide berms building, beach width is generally less than $50 \mathrm{~m}$ but may be up to $>60 \mathrm{~m}$ and there is generally still an extensive low tide terrace present (Fig. 6.10, intermediate profile). As gravel input increases and the mid-bay profiles reach their peak widths (generally $60-100 \mathrm{~m}+$ ) the lower foreshore becomes more convex with multiple storm berms (Fig. 6.9, Sb\# 1, 2 and 3 ) and the low tide terrace becomes narrower relative to the profile width 
and steeper with a cusp morphology often developing (depending on other factors including beach orientation) (Fig. 6.10, final stage profile).

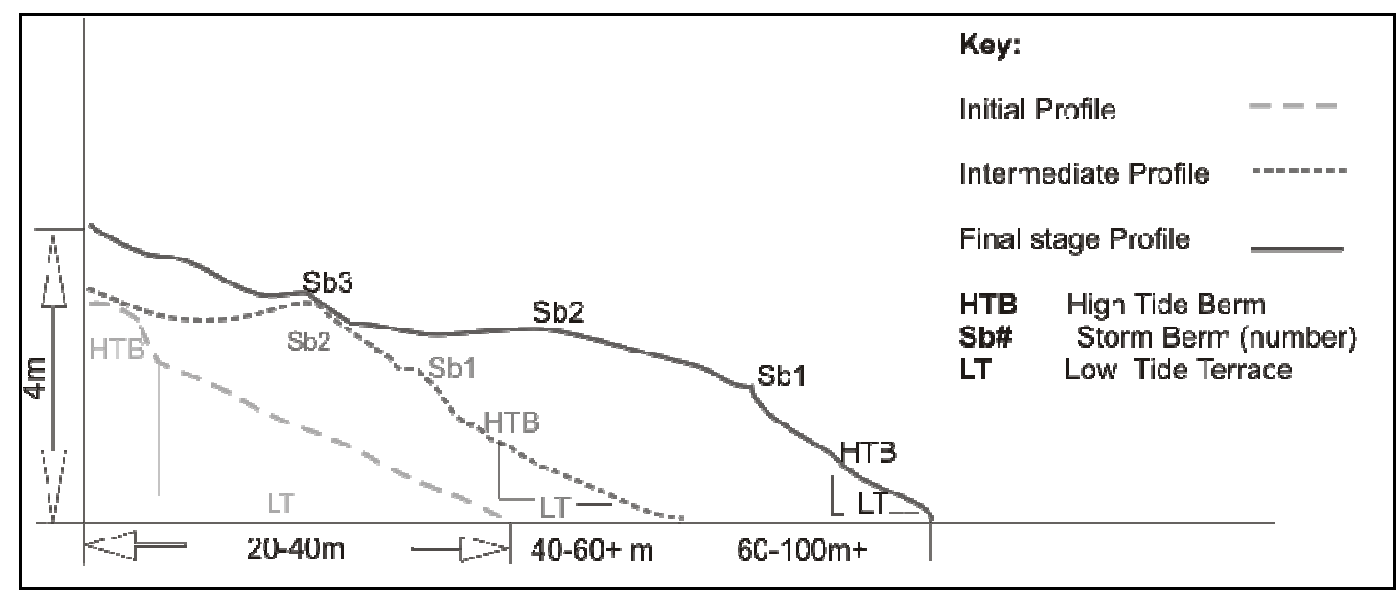

Figure 6.10: Cross shore beach evolution model for mid-embayment profile showing three stages of development with progradation from the gravel front.

The beaches on the more linear and drift-aligned stretches of the coastline may not exhibit this cross shore beach morphology as sediment bypasses them more efficiently restricting beach width to $\sim 20-40 \mathrm{~m}$, but the temporal results from chapter five show that they have still significantly accreted as the front has moved past them between 1941 and present.

The sediment analysis conducted for this project, which is supported by Matthews' (1980a) findings, show that sand content does not move longshore with the gravel, but moves discretely through the subtidal zone and is redistributed on the shore. Although no clear pattern of mean grain size in the gravel fraction was observed spatially, the proportion of sand to gravel increased with distance from the source, particularly in the backbeach and low tide terrace zones either side of Point Webb. The sand is present as extensive areas of sand size sediments and active dunes such as those found in the backbeach zones of northern Robinson Bay and Rona Bay. They are likely to be remnant of the sandy system that has been operating through this section of the coast, with gravel size sediment now building out seaward of these sandy sediment zones. 


\subsection{Significance of gravel on beach stability}

Given the extent of coastal erosion experienced in Eastbourne throughout much of the $20^{\text {th }}$ Century, from a coastal management perspective, the accumulation of gravel along the beachface is a positive outcome. It has provided a natural buffer to erosion as the beach is prograding, reducing wave inundation distances and rendering some of the hard engineering mitigation structures redundant, including the removal of the metal groyne system in recent years.

This research shows, however, that the Eastbourne Coastline is a very sensitive system, as evidenced by the rapidity of the onset of the gravel front. Gravel and mixed beaches have been shown to be highly sensitive to changes in boundary conditions (Forbes et al., 1991). The lack of onshore-offshore sediment recycling on gravel beaches means that beach stability is heavily dependent on continual longshore supply of sediment (Kirk, 1980). If these supply rates are reduced significantly, it will be hard to predict the morphological response of this system (Tait et al., 2002). However, it may be presumed that beach response would be rapid given the quick response times of the system to previous changes. This is important for any future landuse considerations. The proposed extension of the H.W. Shortt Recreation Grounds in 2004/5, for example, was suggested on the basis that this site had experienced up to $60+$ metres of progradation during the 1990s and 2000s, however, it would be unwise to presume that such a dynamic system could not change significantly on an engineering timescale. Regardless of the apparent stability of any beach system, development on an active beach should be preceded by serious consideration and understanding of potential consequences. 


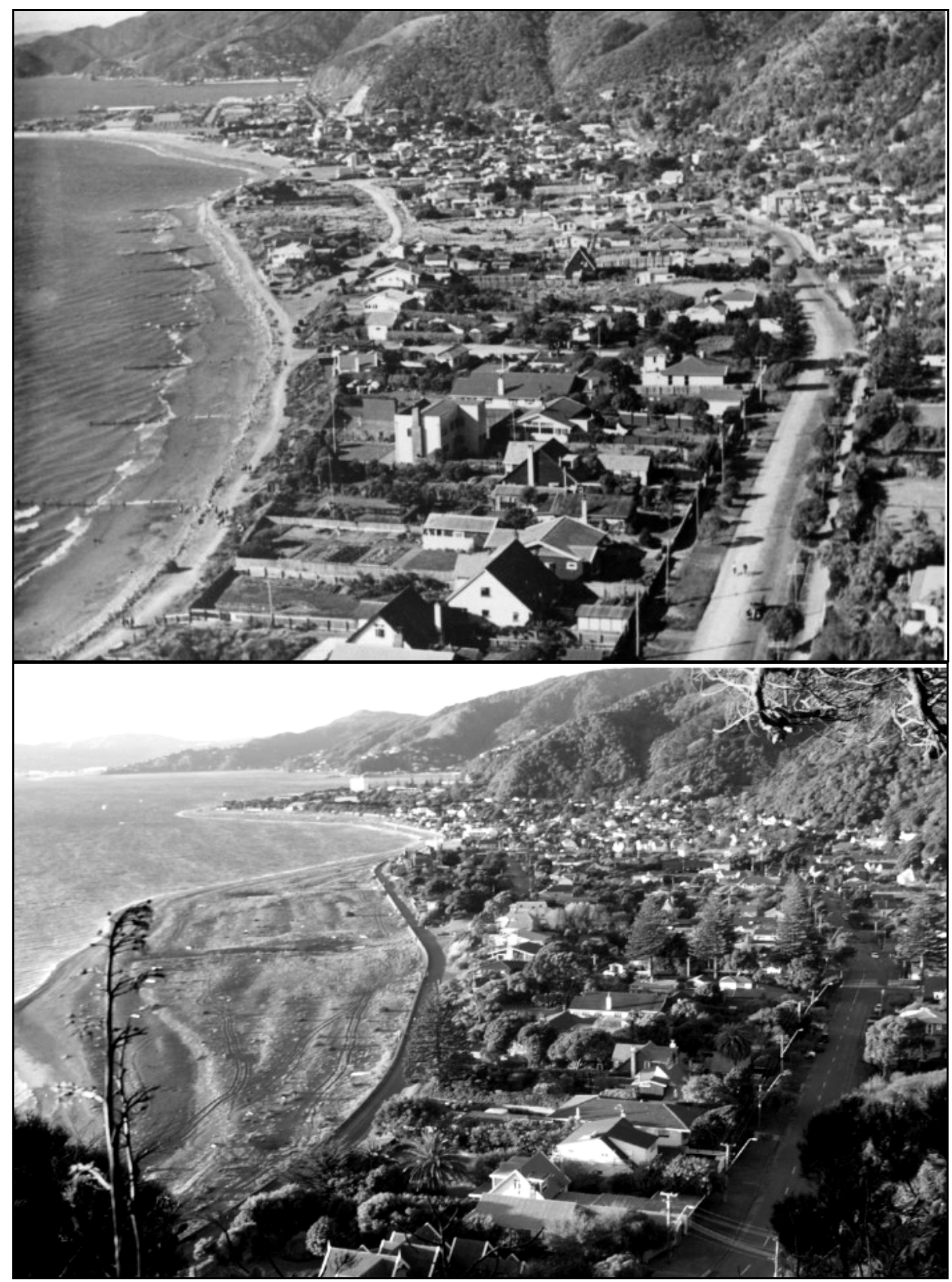

Figures 6.11: View of the southern prograding section at Robinson Bay looking north. Image top shows the section in 1960 (courtesy of the Eastbourne Historical Society). Image bottom shows the area in 2008 (courtesy of John Butt).

\subsection{Stability and sea level change}

Sea-level in Wellington Harbour has risen $>15 \mathrm{~cm}$ since 1899 (Fig. 6.12) (Hannah, 1990). Future sea-level rise for 2050 has been projected to be of the order of $0.14-0.18 \mathrm{~m}$ above 1990 levels (Tait et al., 2002). These 
projections will also be influenced by decadal sea-level oscillations such as the Interdecadal Pacific Oscillation.

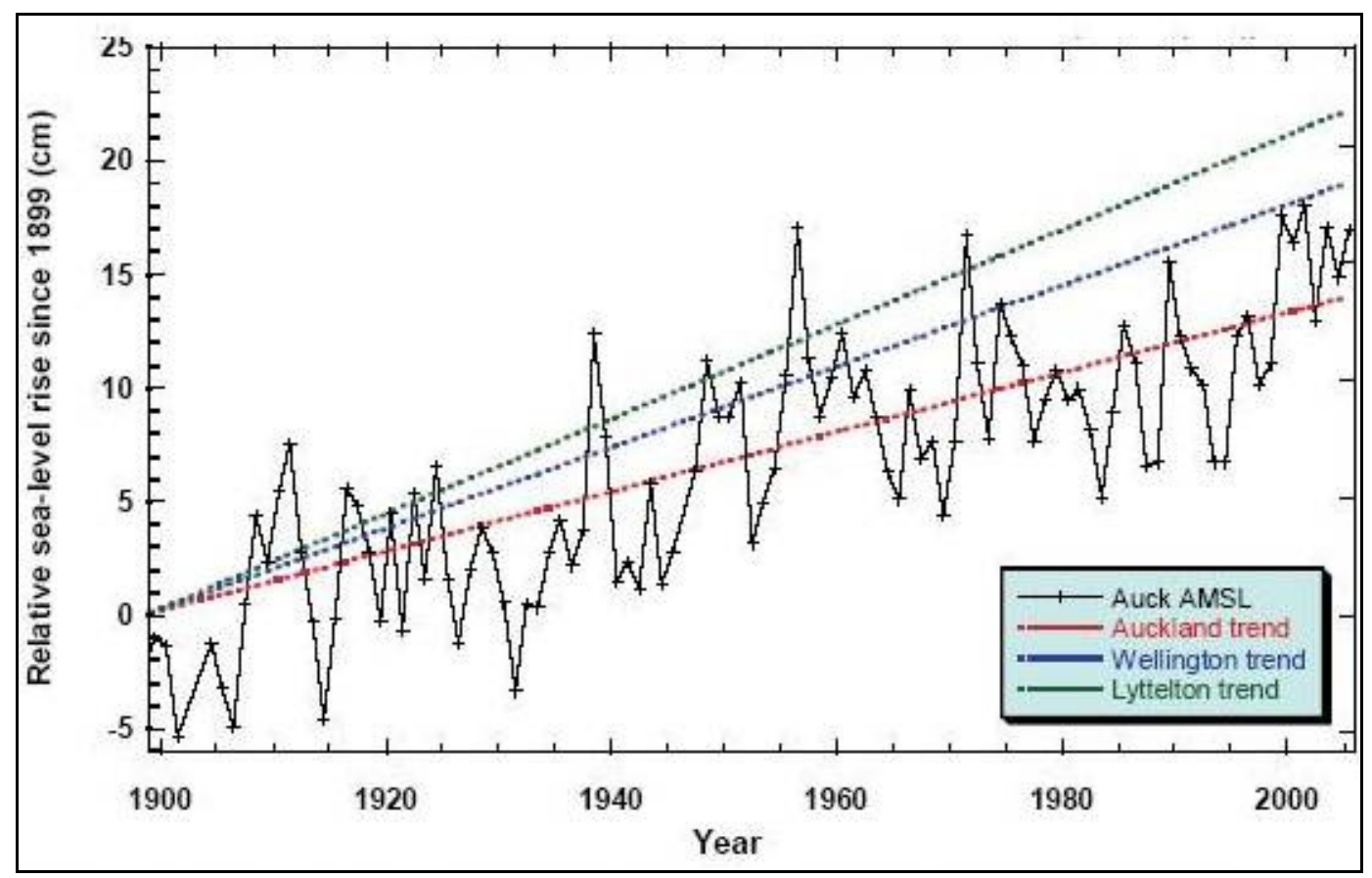

Figure 6.12: sea-level rise in New Zealand's main centres since 1900. The Wellington trend, shown in blue, is discussed in the text (Hannah, 2004).

Assuming all other variables are constant, the projected sea-level rise will produce the following effects on Wellington's beaches:

1. Beaches in a state of erosion, or dynamic equilibrium will experience increased rates of erosion.

2. Beaches currently accreting will continue to do so but at reduced rates

3. Gravel beaches will continue to roll back, but produce higher berms (Tait et al., 2002).

Eastbourne and Pencarrow's beaches may respond in a more complex manner than suggested above, as they combine aspects of gravely beaches and accretional beaches, and are located in a fetch-limited environment. Estuarine response to sea-level rise (which may serve as a proxy for a inner harbour setting) has been suggested to be in the form of either parallel shoreline retreat (Nordstrom and Jackson, 1992) or 
shoreline retreat through landward rollover where vertical upward movement keeps pace with sea-level rise, and horizontal landward movement maintains the beach position in the longitudinal energy frame (Pethick, 2001).

In Eastbourne this would more likely follow the model of Pethick, as gravel beach response to sea-level rise is also generally in the form of rollover/overstepping (Forbes et al., 1991). This involves beach transgression as material is re-deposited in the landward side of the storm berm (Dawe, 2006) and may also result in steepening of the lower foreshore zone of beach profiles.

Tait et al. (2002) have suggested that this response is complicated by additional driving forces to sea-level rise. This includes storms, wave variation, winds, tides and sediment supply, which are variables that will most likely also be affected by climate change. They also note that for Wellington, the largest change to shoreline stability will be through a combination of sea-level rise altering sediment supply (river supply and coastal erosion supply), and changes in wave climate (Tait et al., 2002). This would have a significant effect on the Eastbourne/Pencarrow littoral cell, as beach stability has been shown to be dependent on continual longshore sediment transport from river sources. This means that in addition to profile adjustment to sea-level, the system may have to contend with a reduced river supply as base levels change in response to sea-level. The exact effects of this combination of sea-level rise, sediment supply change and littoral cell response are outside of the scope of this study, and warrant further modelling. 


\section{Chapter Seven: Conclusions}

\subsection{Introduction}

This chapter has been written to summarise the main findings of this research project in reference to the research aim and objectives identified in Chapter One. The aim was to answer the central research question:

Does the observed shoreline change in Eastbourne relate to a long term shift in the systems sediment supply, or are these changes the result of a temporary cycle from where the system will revert back to an erosional phase?

More specifically, this research aimed to:

1. Quantify rates of erosion and accretion through topographic surveying and aerial photo analysis, allowing for an accurate description of beach morphology, and temporal stability over decadal timescales to be constructed.

2. Identify the thresholds driving shoreline advance and retreat in Eastbourne and Pencarrow by exploring the response of a gravel beach system to a range of variables including uplift, longshore transport and changes in sediment supply from sandy to coarse sized sediment.

3. Assess the sensitivity of the Eastbourne shoreline system and its likelihood to return to an erosional phase through aerial photograph analysis, particularly the rates of shoreline movement on temporal scales. This includes an assessment of the influence of climate-change induced sea-level rise.

This study, conducted with regard to the above objectives, has made the several key findings on the stability of the Eastbourne shoreline, as summarised below. 


\subsection{Main findings of this research project}

\subsubsection{Permanence of the coastal changes at Eastbourne}

The most significant finding to come out of this study relates to whether the change currently observed along Eastbourne's shoreline is a short term beach adjustment to a gravel pulse, or a more permanent adjustment relating to longer term changes in supply and/or transport processes. The temporal results of this research have indicated a more permanent change to the morphology and sedimentology of this coastline. The historical aerial photographs analysed have shown significant net progradation over 67 years between the Orongorongo River in Pencarrow and Days Bay $20 \mathrm{~km}$ to the north, with smaller annual erosion/accretion cycles superimposed on the longer term decadal shoreline advance.

\subsubsection{Shoreline evolution model}

The conceptual model of shoreline evolution for Eastbourne and Pencarrow developed from this research is based on the temporal results, spatial surveying and field observations. These results were combined with the findings of Matthews (1980a, b) and theories of MSG beach response, longshore drift in MSG beach systems, and fetch-limited beach response as discussed in Chapter Two. This conceptual model suggests that the system is still adjusting to the introduction of a large volume of fine grained sediment along the east harbour coastline sourced from nearshore areas uplifted during the 1855 Wairarapa Earthquake. Additionally, increased volumes of gravel sized sediment have been inputted into the littoral system following the 1855 uplift event. This has been in response to increased sediment supply and base level change, not as a unique pulse of sediment caused by earthquake- induced landsliding. This has changed the sedimentary composition of the beaches, which still show signs of being in adjustment to the input of an increased sediment supply. The mechanism of this adjustment was presented in Chapter Six as a five stage beach evolution model (Fig. 6.) 
showing longshore sourced sediment leading to progradation of individual beaches in the littoral cell. Once these beaches fill to a threshold, sediment is able to bypass them and continue the process in the next downdrift embayment to the north.

\subsubsection{Northern migration rates of the gravel front}

The results of this study show gravel component of the sediment flux is migrating northward sub-aerially through the swashzone at an average rate of $0.17 \mathrm{~km} / \mathrm{y}$, which is significantly slower than Matthews' (1980) rate of $0.42 \mathrm{~km} / \mathrm{y}$. This discrepancy can be reconciled by the fact that both studies calculated their rates using different techniques and timescales, as explained in detail in Chapter Five.

\subsubsection{Shoreline accretion quantities and rates of movement}

The temporal results have also shown that $>90 \%$ of the coastline measured has shown net progradation of 20-100+ m between 1941 and 2008, with only small stretches of beach showing overall erosion through mid Robinson Bay (relating to the sea wall location). Average annual rates of this shoreline movement were calculated as between -0.21 and $1.23 \mathrm{~m} / \mathrm{yr}$ for the whole study area over 67 years, with higher rates through Rona Bay from 1941-1969, and through Robinson Bay in later decades. In Robinson Bay, the main study site, there are two sections of the beach that have shown maximum progradation of up to $70-100 \mathrm{~m}$ between 1985 and present, at a rates of up to $4 \mathrm{~m}$ per year.

\subsubsection{Beach morphological variation}

Another key objective of this study was to accurately describe beach morphology and quantify the shoreline variation in Eastbourne, both spatially and over monthly timescales. This was achieved through surveying 64 beach profiles from Days, Rona, and Robinson Bays, with repeat surveying of nine profiles in northern Robinson Bay to show the 
effects of seasonality. The spatial surveying showed that beach width varied between 10 and $120 \mathrm{~m}$, and that cross sectional morphology ranged from narrow flat sandy beaches through Days Bay, to broad convex multiberm gravel beaches in parts of Robinson Bay. Repeat surveys showed seasonal variation operating through Robinson Bay, mostly in the form of northward translation of sediment over time, as the southern surveyed profiles reduced in cross sectional area by roughly the same amount that the northern profiles increased by over the one year of surveying. This was discussed in more detail in Chapter Five.

It can be concluded from these results that Rona and Robinson Bay beaches are adjusting to a change in sediment type, and are in varying stages of adopting a mixed sand and gravel (MSG) beach morphology, as modelled by Kirk (1980). The surveying has shown however, that they are operating on a smaller spatial scale than Kirk's model due to their location in a limited fetch environment.

\subsubsection{Sediment size analysis}

Sediment analyses of a total of 77 sand and gravel samples show the grain size distribution through the study area. Grain size ranged from finemedium sand $<3 \Phi(0.125 \mathrm{~mm})$, to coarse pebble sized gravel $>-5 \Phi$ $(32 \mathrm{~mm})$. It was found that mean grain size was highly variable both long and cross shore with no clear longshore linear mean grain size grading pattern and some cross shore sediment size zonation, mainly in the form of coarse clasts situated on berm crests. It was however noted but the proportion of sand increased with distance from the main sources, which may be a result of clast attrition and/or inheritance from the previously sandy system. 


\subsubsection{Drivers of change and future predictions}

The thresholds driving the erosion/accretion cycles in Eastbourne and Pencarrow have been identified as tectonic uplift (which sets the boundary conditions for the observed coastal change), and longshore drift rates. The role of longshore drift is the predominant control on beach stability under current conditions. This was found to be spatially variable along the coastline in response to reduced wave energy and roughness (from topographic variation). Transport rates were shown to be highest in the northern section of the littoral cell, in the years 1975-2008. This was the opposite effect that would have been predicted on the sole basis of wave energy reduction rates. It was therefore concluded that the relative roles of wave energy and roughness were variable through the cell, with roughness increasing through central Pencarrow and reducing through Camp Bay and the Eastbourne cuspate foreland. This has affected transport rates as shown in Chapters Five and Six. It was also predicted on the basis of this that a threshold exists north of Point Webb between Rona and Robinson Bays where wave energy is significantly reduced, and despite lower coastal roughness, transport rates would decrease rapidly. However, Days Bay beach to the north of this has been shown to be in transition from a sandy system through the northern and central parts, into a mixed sand and gravel system through the southern reaches, marking the present northern limit of the gravel front. This has suggested that although rates will be reducing, there is enough energy and sediment moving through the littoral cell to continue the process of gravel migration north.

\subsection{Suggested future research}

This project has been a morphology-based assessment of shoreline stability. While it has been accepted that the southerly swell waves are primarily responsible for (Matthews, 1980), southerly and northerly sea waves generated from within the harbour complicate. Additionally, longshore transport processes remain poorly understood in MSG beach 
systems compared to sandy beaches Therefore, a more detailed study into process dynamics in Eastbourne and Pencarrow would be highly beneficial and complimentary to the present study. It would be useful to extend the topographic surveying further round the Pencarrow coast up to the Orongorongo River, and to initiate a more extensive sediment monitoring program based on the results presented in this thesis. If possible, updated studies of sedimentation rates of the Orongorongo River onto the continental shelf would help to validate the findings of this project, along with a sediment budget and landslide scar assessment of the Orongorongo catchment.

\subsection{Concluding remarks}

This thesis has provided an interesting opportunity to see how a mixed sediment beach system operating within a limited-fetch environment compares to established models of beach response, which are more frequently directed toward sandy beaches and open-ocean coarse grained beaches. The results have shown that this study area combines aspects of both MSG and estuarine/harbour beach morphology, and this has resulted in a complex pattern of shoreline adjustment. The findings of this research suggest that this adjustment to Eastbourne's coastline is part of a long-term change to the entire littoral cell, and, providing that current conditions are sustained, it is unlikely that this study area will return to the small erosion/accretion cycles observed through the $20^{\text {th }}$ century. 


\section{REFERENCES}

Anthony, E. J. 2009. Ch. 6: Gravel Beaches and Barriers. Shore Processes ad their Paleoenvironmental Applications. Elsevier, Developments in Marine Geology 4: 289-322.

Austin, M. J. and G. Masselink. 2006. Observations of morphological change and sediment transport on a steep gravel beach, Marine Geology 229 (1-2): 59-77.

Beaglehole, A. and A. Carew. 2001. Eastbourne. a History of the Eastern Bays of Wellington Harbour. The Historical Society of Eastbourne. 2001, First Edition. 318pp.

Begg, J. G. and M. R. Johnston. 2000. Geology of the Wellington area. Lower Hutt, New Zealand, Institute of Geological and Nuclear Sciences.

Beuselink, L. Govers, G., Poesen, J., Degraer, G. and L. Froyen. 1998. Grain-size analysis by laser diffractometry: comparison with the sieve-pipette method. Catena 32: 193-208.

Bird, E.C.F.1976. An Introduction to Systematic Geomorphology Vol.4 (2 $2^{\text {nd }}$ ed). Australian National University Press, Canberra. 282pp.

Bishop, R.G. 1976. Report on Storm of 20 December, 1976. Wellington Regional Water Board Reports, Wellington. 66pp.

Bluck, B. 1967. Sedimentation of beach gravels: Examples from South Wales. Journal of Sedimentary Petrology 37: 128-156.

Bruun, P. 1962. Sea-level rise as a cause of shore erosion. Journal of the Waterways and Harbours Division, American Society of Civil Engineers 88: 117-130.

Buscombe, D. and G. Masselink. 2006. Concepts in gravel beach dynamics, Earth Science Reviews 79 (1-2): 33-52.

Caldwell, N.E. and A.T. Williams. 1986. Spatial and seasonal pebble beach profile characteristics. Geological Journal 21: 127-138.

Carter, L. 1977. Sand transport, Wellington Harbour entrance, New Zealand, N.Z. Journal of Geology and Geophysics 20 (2): 335351pp.

Carter, L and Gibb, J. 1985. Days Bay - beach stability. Report prepared for the Eastbourne Borough Council. 30pp. 
Carter, L. and J. S. Mitchell. 1988. Side-scan sonar survey, Wellington Harbour entrance. Report prepared for Wellington City Council. $19 \mathrm{pp}$.

Carter, R.W.G., Ordord J.D., Forbes,. D.L., and Taylor R.B. 1990. Morphosedimentary development of drumlin flank barriers with rapidly rising sea level, Storyhead, Nova Scotia. Sedimentary Geology 69: 117-138.

Carter, L. and Lewis, K. 1995. Variability of the modern sand cover on a tide and storm driven inner shelf, south Wellington, New Zealand, New Zealand Journal of Geology and Geophysics 38: 451-470.

Cooper, N. J., Leggett, D. J. and J. P. Lowe. 2000. Beach-profile measurement, theory and Analysis: Practical guidance and applied case studies: 79-88.

Cotton, C. A. 1974. Bold Coasts: Annotated Reprints of Selected Papers on Coastal Geomorphology, 1916-1969. A. H. \& A. W. Reed, Wellington. 354pp.

Dawe, I. N. 1997. Sediment Patterns on a Mixed Sand \& Gravel Beach, Kaikoura, N.Z. Unpublished MSc Thesis. Department of Geography, University of Canterbury. 184pp.

Dawe, I.N. 2001. Sediment patterns on a mixed sand and gravel beach , Kaikoura, New Zealand. Journal of Coastal Research Special Issue 34:267-277.

Dawe, I. N. 2006. Longshore Sediment Transport on a Mixed Sand and Gravel Lakeshore. Unpublished PhD Thesis. Department of Geography, University of Canterbury. 361pp.

Engels, S. and M.C. Roberts. 2005. The architecture of prograding sandygravel beach ridges formed during the last Holocene highstand: southwestern British Columbia, Canada. Journal of Sedimentary Research. 75: 1052-1064.

Folk, R. L. and W. C. Ward. 1957. Brazos River bar: a study in the significance of grain size parameters. Journal of Sedimentary Petrology, 27: 3-26.

Forbes, D.L., Taylor, R.B., Orford, J.D., Carter, R.W.G. and J. Shaw. 1991. Gravel-barrier migration and overstepping. Marine Geology 97: 305-313.

Gale, S.J., and P.G. Hoare. 1991, Quaternary sediments: Petrographic methods for the study of unlithified rocks: New York, Wiley, $323 \mathrm{pp}$. 
Gibb, J. G. 1978. Rates of coastal erosion and accretion in New Zealand, N.Z. Journal of Marine and Freshwater Research 12 (4): 429-436.

Gibb, J. G. 2005. Review of proposed reclamation effects at H.W. Shortt Park, Eastbourne. Report prepared for Hutt City Council. 7pp.

Goff, J.R., Dunbar, G.B. and P.J. Barrett. 1998. Monthly to Decadal Sediment Accumulation Rates in a Semi-Enclosed Embayment. Journal of Coastal Research 14(2): 461-471.

Hannah, J. 1990. Analysis of mean sea level data from New Zealand for the period 1899-1988. Journal of Geophysical Research, 95 (B8), 12,399-12,405.

Hannah, J. 2004. An updated analysis of long term sea level change in New Zealand. Geophysical Research Letters, 31, L03307.

Harris, T.W.F. 1990. Greater Cook Strait: Form and Flow. Wellington. Wilson and Horton Ltd. 212pp.

Hastie, W.J. 1989. East Wellington Harbour and south coast coastal mining investigation. Technical Report L1989/1 Land Information Department Wellington Regional Council. 52pp.

Hegge, B., Eliot I. and J. Hsu. 1996. Sheltered sandy beaches of southwestern Australia. Journal of Coastal Research 12: 748-760.

Horn, D.P. and S. M.Walton. 2007. Spatial and temporal variations of sediment size on a mixed sand and gravel beach, Sedimentary Geology 202: 509-528.

Huang, J., Jackson, D.W.T. and J.A.G. Cooper. 2002. Morphological monitoring of a high energy beach system using GPS and total station techniques, Runkerry, Co. Antrim, Northern Ireland. Journal of Coastal Research S.I. 36: 390-398.

IPCC. 2007. Summary for Policy makers Climate Change 2007: The Physical Science Basis. In Contribution of Working Group I to the Fourth Assessment Report of the Intergovernmental Panel on Climate Change, edited by S. Solomon, D. Qin, M. Manning, Z. Chen, M. Marquis, K. B. Averyt, M. Tignor and H. L. Miller. Cambridge: Cambridge University Press.

Ivamy, M. C. and P. S. Kench. 2006. Hydrodynamics and morphological adjustment of a mixed sand and gravel beach, Torere, Bay of Plenty, New Zealand, Marine Geology 228: 137-152.

Jackson, N. L. and K. F. Nordstrom. 1992. Site specific controls on wind and wave processes and beach mobility on estuarine beaches in New Jersey, U.S.A. Journal of Coastal Research 8 (1): 88-98. 
Jennings, R. and J. Shulmeister. 2002. A field based classification scheme for gravel beaches. Marine Geology 186: 211-228pp.

Kennedy, D. M. 2002. Estuarine beach morphology in microtidal Middle Harbour, Sydney. Australian Geographical Studies 40 (2): 231 240.

Kirk, 1967. Beach Morphology and Sediments of the Canterbury Bight. Unpublished M.A. thesis, Department of Geography, University of Canterbury No. 107. 173pp.

Kirk, R. M. 1975. Aspects of surf and runup processes on mixed sand and gravel beaches. Geografiska Annaler Series A 57: 117-133.

Kirk, R. M. 1980. Mixed sand and gravel beaches: morphology, processes and sediments. Progress in Physical Geography 4: 189-210.

Komar, P.D. and Cui, B. 1984. The analysis of grain-size measurements by sieving and settling-tube techniques. Journal of Sedimentary Petrology 54: 603-614.

Kulkarni, C.D., Levoy, F., Monfort, O. and J. Miles. 2004. Morphological variations of a mixed sediment beachface (Teignmouth, UK) Continental Shelf Research 24: 1203-1218.

Krumbein, W.C. 1934. Size frequency distributions of sediments. Journal of Sedimentary Petrology 4 (2): 65-77.

Leeder, M.R. 1982. Sedimentology: Process and Product. George Allen \& Unwin, London. 551pp.

Le Roux, J. P. 1998. Entrainment threshold of natural grains in liquids determined empirically from dimensionless settling velocities and other measures of grain size. Sedimentary Geology 119:17-23.

LINZ. 2007. LINZ Geodetic database. Retrieved on 25 February 2009 from http://www.linz.govt.nz/geodetic/

Lippmann, T. C., and R. A. Holman. 1990. The Spatial and Temporal Variability of Sand Bar Morphology, Journal of Geophysical Research, 95(C7), 11,575-11,590.

Loizeau, J.L., Arbouille, D. and S. Santiago. 1994. Evaluation of a wide range laser diffraction grain size analyser for use with sediments. Sedimentology 41: 353-365.

McCave, I.N., Bryant, R.J., Cook, H.F. and C.A. Coughhanowr. 1986. Evaluation of a laser-difraction-size analyzer for use with natural sediment. Journal of Sedimentary Research 56 (4): 561-564. 
McConchie J. 2000. From shaky beginnings. In: McConchie J et al (eds) Dynamic Wellington. Institute of Geography, Wellington: 9-34.

McLaren, P. 1981. An interpretation of trends in grain size measures. Journal of Sedimentary Petrology 51:611-624.

McLean, R. F. 1970. Variations in grain-size and sorting on two Kaikoura beaches. New Zealand Journal of Marine and Freshwater research 4: 141-164.

McLean, R. F. and R. M. Kirk. 1969. Relationships between grain size, size-sorting, and foreshore slope on mixed sand-shingle beaches. N.Z. Journal of Geology and Geophysics 12 (1): 138-155.

McSaveney, M. J., Graham, I. J., Begg, J. G., Beu, A. G., Hull, A. G., Kim, K. and A. Zondervan. 2006. Late Holocene uplift of beach ridges at Turakirae Head, south Wellington coast, New Zealand, New Zealand Journal of Geology and Geophysics 49: 337-358.

Marshall, P. 1929. Beach gravels and sand. Transactions of the New Zealand Institute 60: 324-365.

Mason, T. and T.T. Coates. 2001. Sediment Transport Processes on Mixed Beaches: A Review for Shoreline Management. Journal of Coastal Research 17 (3): 645-657.

Masselink, G., Hegge, B.J. and C.B. Pattiaratchi. 1997. Beach cusp morphodynamics. Earth Surface Processes and Landforms 22, 1139-1155.

Matthews, E. R. 1980a. Observations of beach gravel transport, Wellington Harbour entrance, New Zealand, N.Z. Journal of Geology and Geophysics 23 (2): 209-220.

Matthews, E.R. 1980b. Coastal Sediment Dynamics, Turakirae Head to Eastbourne, Wellington, N.Z.O.I. Oceanographic Field Report no. 17. $21 \mathrm{pp}$.

Matthews, E.R. 1982. Dynamics of mixed sand and gravel beaches between Cape Palliser and Wellington, New Zealand. Unpublished $\mathrm{PhD}$ thesis lodged in the library, Victoria University, Wellington. 324pp.

Muller, G. 1967. Methods in Sedimentary Petrology: Stuttgart, E. Schweizerbart'sche Verlagsbuchhandlung, 283 pp.

New Zealand Meteorological Service. 1981. The Climatology of Wellington Airport. N.Z. Meteorological Service Miscellaneous Publication 171 (1) $25 \mathrm{pp}$. 
Met Service. 2009. New Zealand Climate. Retrieved December 12009 , from http://www.metservice.co.nz/national/

Nolan, T.J, Kirk, R.M. and Shulmeister, J. 1999. Beach cusp morphology on sand and mixed sand and gravel beaches, South Island, New Zealand. Marine Geology 157: 185-198pp.

Nordstrom, K. F. 1992. Estuarine Beaches. Elsevier Applied Science, London. 225pp.

Osborne, P. D. and W. Chen. 2005. Wave-induced gravel and cobble transport on a crenulate shoreline of a large inlet, Grays Harbour, Washington. Scientific report prepared for: Canadian Coastal Conference 2005.

Orford, J.D. and Carter, R.W.G. 1995. Examination of mesoscale forcing of a swash-aligned, gravel barrier from Nova Scotia. Marine Geology 126: 201-211.

Orford, J.D., Carter, R.W.G. and Jennings, S.C. 1996. Control domains and morphological phases in gravel-dominated coastal barriers of Nova Scotia. Journal of Coastal Research 12 (3): 589-604.

Pallentin, A., Verdier, A. L. and J. Mitchell. 2009. Wellingon Harbour Multibeam Survey. NIWA Client Report for the Department of Conservation and the Greater Wellington Regional Council. 9pp.

Pethick, J. 2001. Coastal management and sea-level rise, Catena 42: 307-322.

Pettijohn, F.J. and J.D. Ridge. 1932. A textural variation series of beach sands from Cedar Point, Ohio. Journal of Sedimentary Petrology 2 (2); 76-88.

Pickrill, R.A. 1985. Beach changes on low energy lake shorelines, Lakes Manapouri and Te Anau, New Zealand. Journal of Coastal Research 1 (4): 353-363.

Pickrill, R.A. and J.S. Mitchell .1979. Ocean wave characteristics around New Zealand. N.Z. Journal of Marine and Freshwater Research 13: 501-502.

Postma, G. and W. Nemec. 1990. Regressive and transgressive sequences in a raised Holocene gravelly beach, southwestern Crete, Sedimentology 37: 907-920. 
Quayle, A. M. 1984. Weather and Sea Conditions of Wellington Harbour and South Coast. Technical Information Circular, N. Z. Meteorological Service.

Revell, C.G. 1981. Tropical cyclones in the Southwest Pacific, November 1969 to April 1979. New Zealand Meteorological Service, Wellington, Miscellaneous Publication 170. 53pp.

Rodriguez, J.G. and Uriarte, A. 2009. Laser diffraction and dry-sieving grain size analyses undertaken on fine- and medium-grained sandy marine sediments: A note. Journal of Coastal Research 25 (1): 257264.

Saville, T. and G.M. Watts. 1969: Coastal regime: recent US experience. United States Army Corps of Engineers, Coastal Engineering Research Center Reprint 3-70pp.

Sherman, D.J., Short, A.D. and I. Takeda. 1993. Sediment mixing-depth and megaripple migration in rip channels. Journal of Coastal Research Special Issue 15: 39-48.

Shih, S. and P.D. Komar. 1994, Sediments, beach morphology and sea cliff erosion within an Orgeon coast littoral cell. Journal of Coastal Research, 10 (1), 144-157.

Short, A.D. 1979. Wave power and beach stages: A global model. Proceedings of the $16^{\text {th }}$ International Conference of Coastal Engineering, Hamburg. 144-157.

Shulmeister, J. and H. Rouse. 2003. Gravel and mixed sand and gravel beach systems. In Goff, J. R. Nichol, S. L. and H.L. Rouse (eds.) The New Zealand coast $=$ Te Tai o Aotearoa. Dunmore Press. 312pp.

Smith, G. L. and G.A. Zarillo, 1990. Calculating Long-Term Shoreline Recession Rates Using Aerial Photographic and Beach Profiling Techniques. Journal of Coastal Research 6 (1): 111-120.

Stevens, G. R. 1974. Rugged landscape. The geology of central New Zealand. A. H. \& A. W. Reed, Wellington. 286pp.

Tait, A., Bell, R., Burgess, S., Gorman. R., Gray, W., Larsen, H., Mullan, B., Reid, S., Sansom, J., Thompson, C., Wratt, D. and M. Harkness. 2002. Meteorological Hazards and the Potential Impacts of Climate Change in Wellington Region. NIWA Client Report WLG2002/19. 155pp.

Thompson, C. S. 1987. Extreme Rainfall Frequencies in New Zealand. New Zealand Meteorological Service Miscellaneous Publication 191:13pp. 
Van Dissen, R. J., and K. R. Berryman. 1996. Surface rupture earthquakes over the last $\sim 1000$ years in the Wellington region, New Zealand, and implications for ground shaking hazard. Journal of Geophysical Research 101(B3), 5999-6019.

Van Orstrand, C.E. 1925. Note on the representation of the distributions of grains in sands. Committee on Sedimentations: Research in Sedimentation 1924-National Research Council. 63-67.

Woodroffe C. D. 2002. Coasts: form, process and evolution. Cambridge University Press. 623pp.

Wright, L.D. and Short, A.D. 1984. Morphodynamic variability of surf zones and beaches: a synthesis. Marine Geology 56: 93-118.

Zenkovich, 1967. Processes of Coastal Development. Oliver and Boyd, Edinburgh. 738pp. 
Appendix 1: Survey Data 


\section{Surveyed Profiles Days Bay}
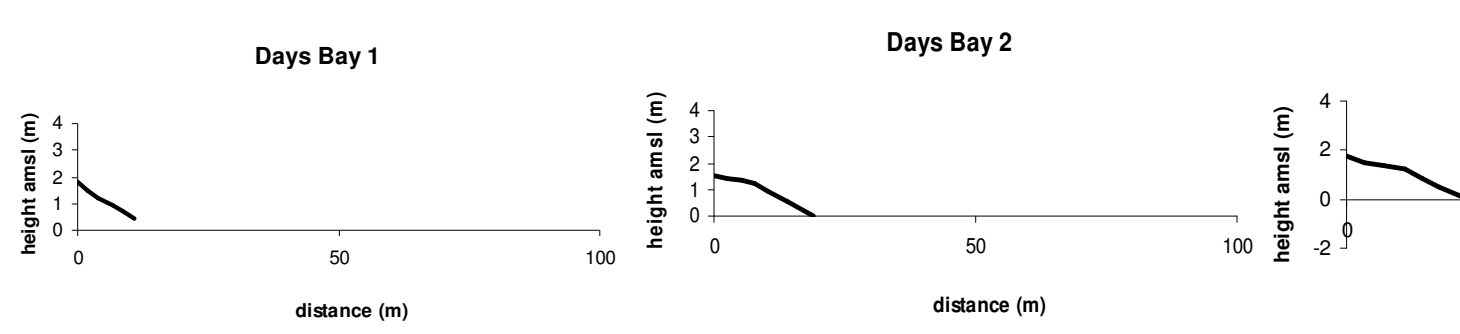

Days Bay 3

Days Bay 4

Days Bay 6
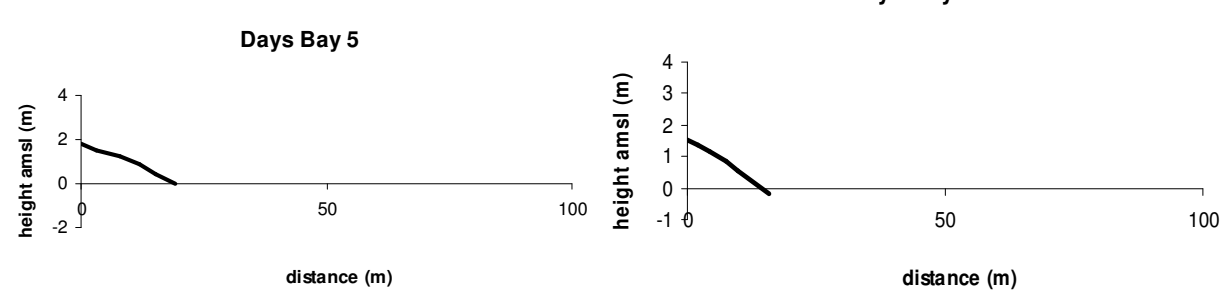

Days Bay 7
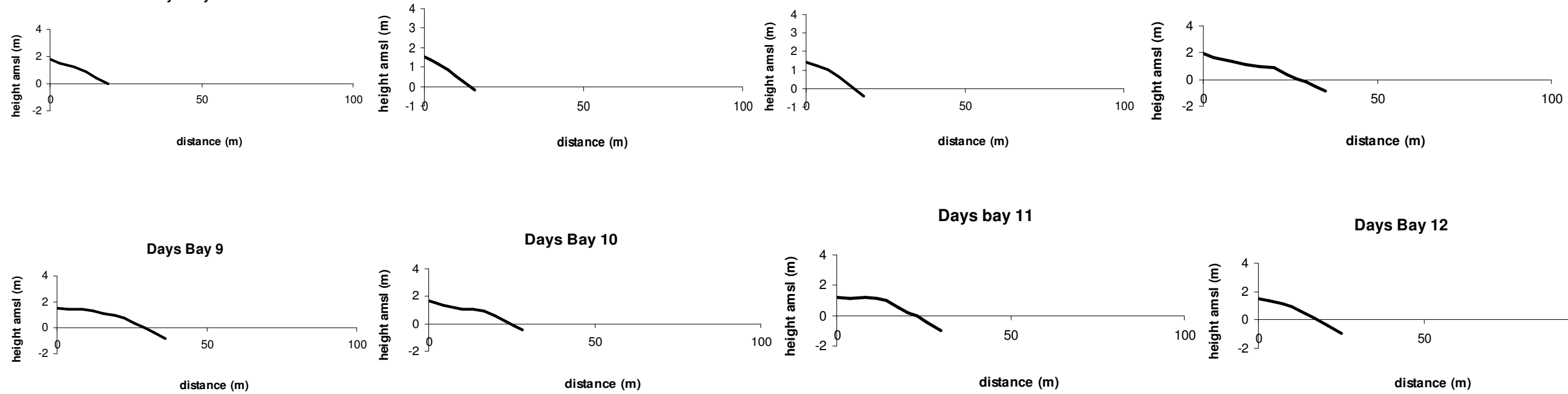

Days Bay 10

Days bay 11

Days Bay 12
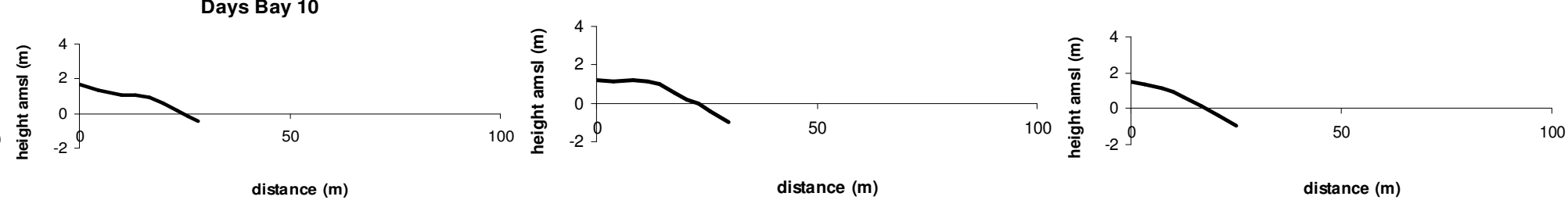

Days Bay 13

Days Bay 14
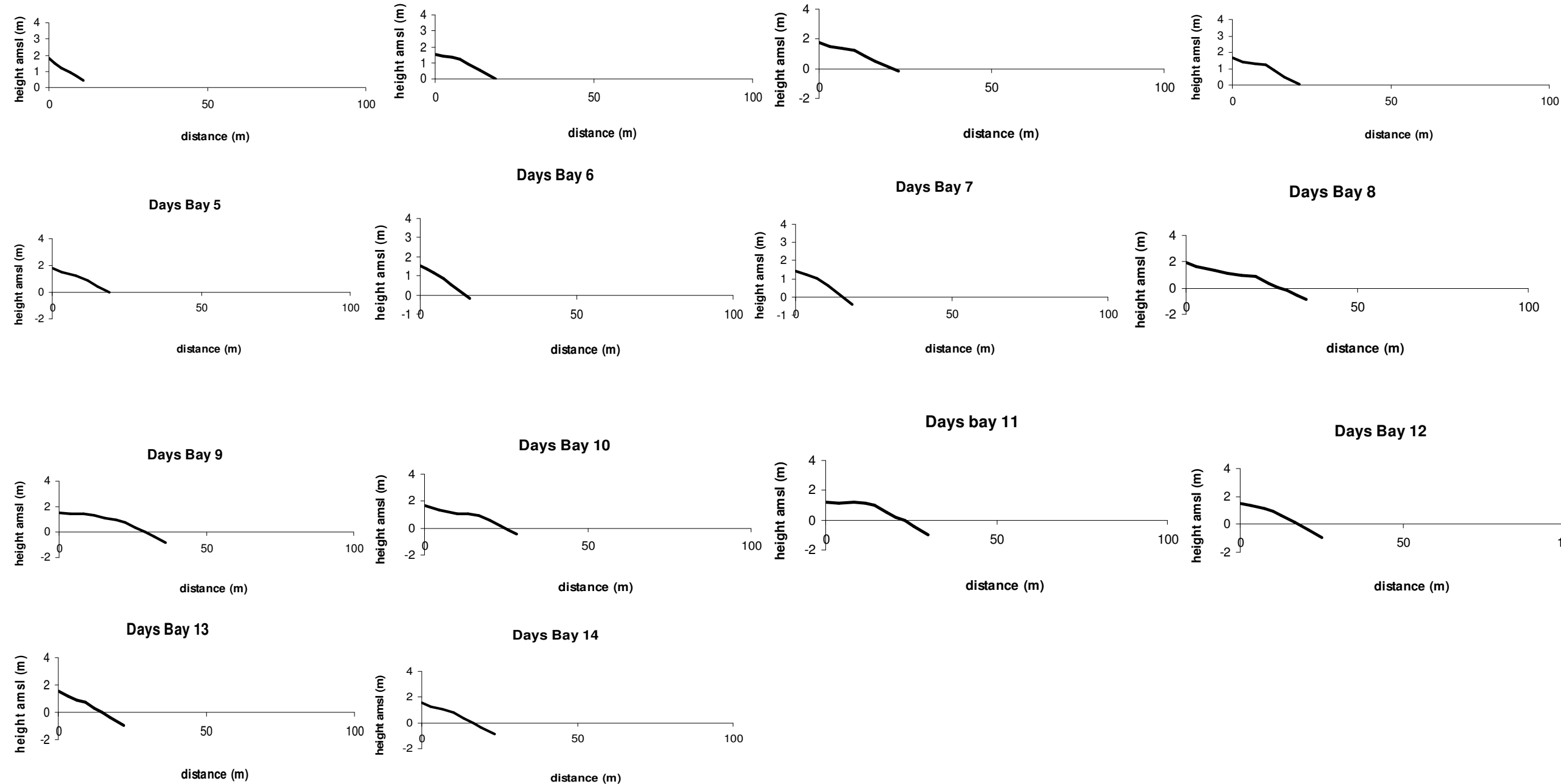

Days Bay 8 


\section{Surveyed Profiles Rona Bay}
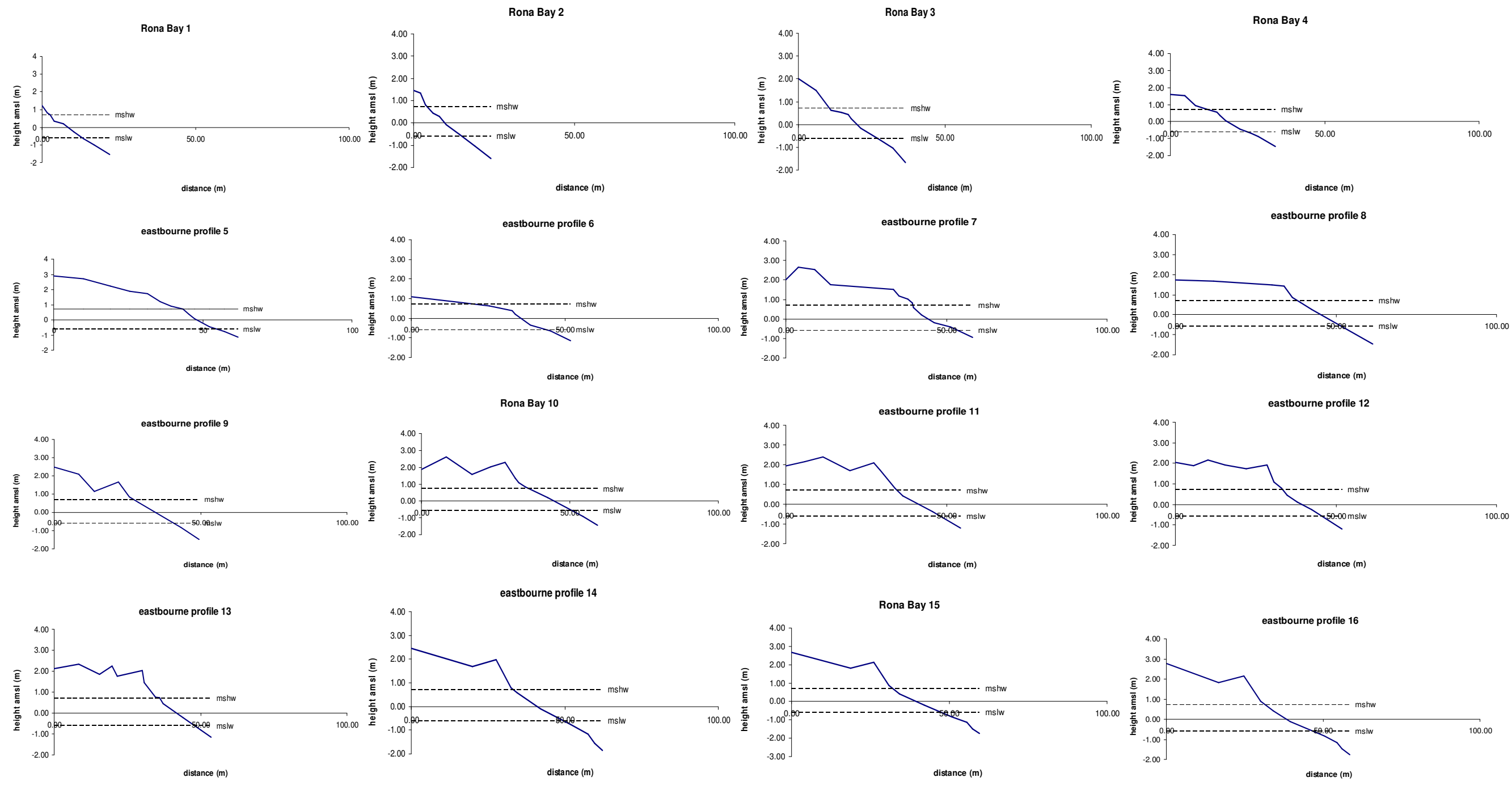

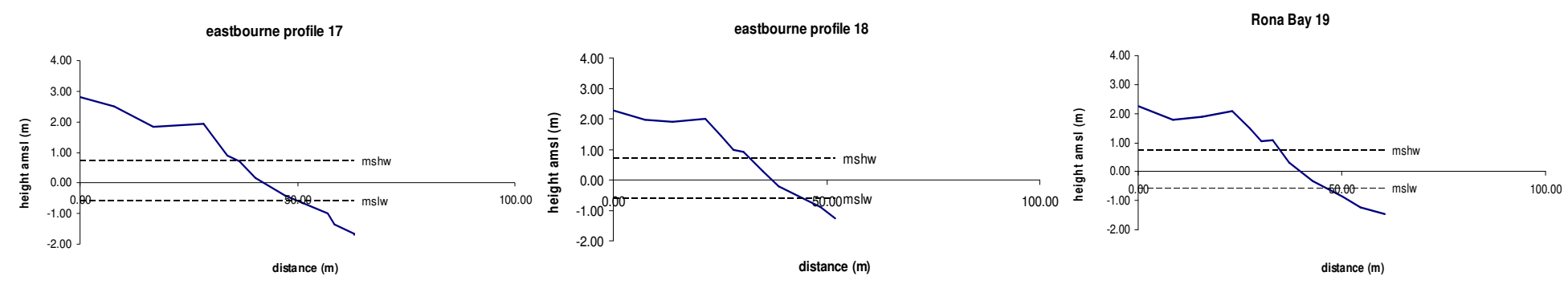

\section{Surveyed Profiles Robinson Bay}
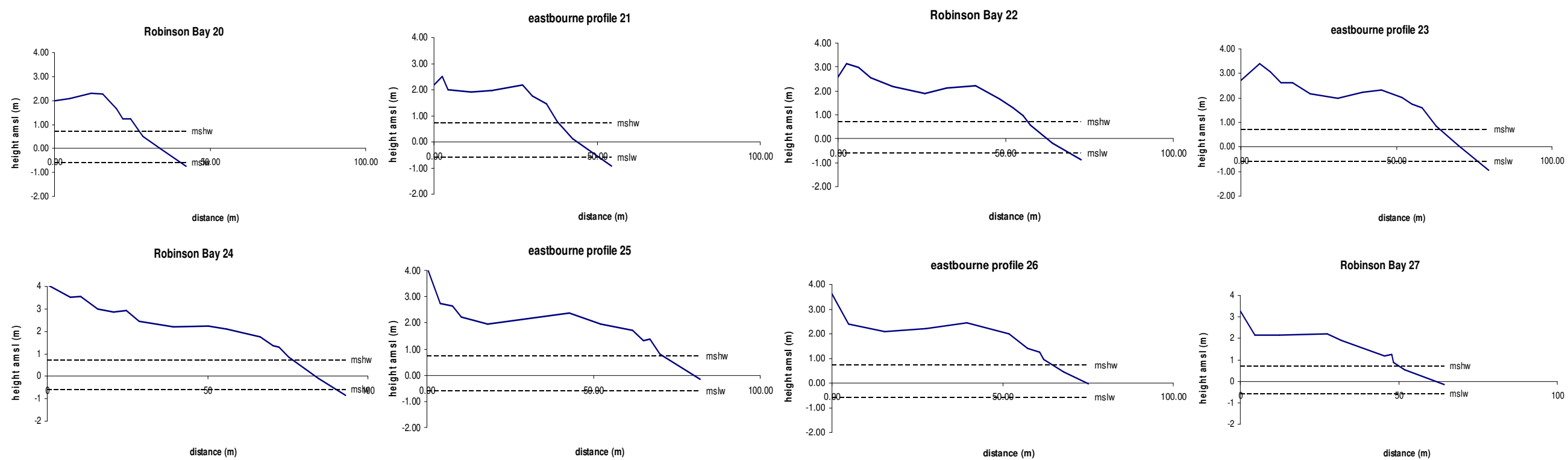
Robinson Bay 29
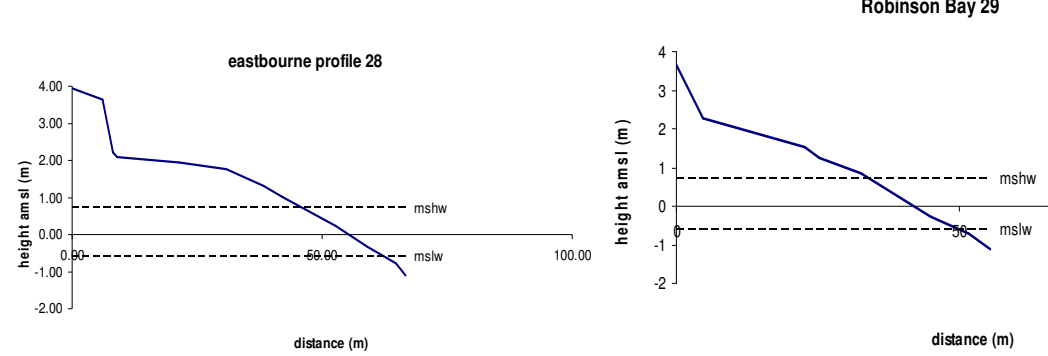

Robinson Bay 30
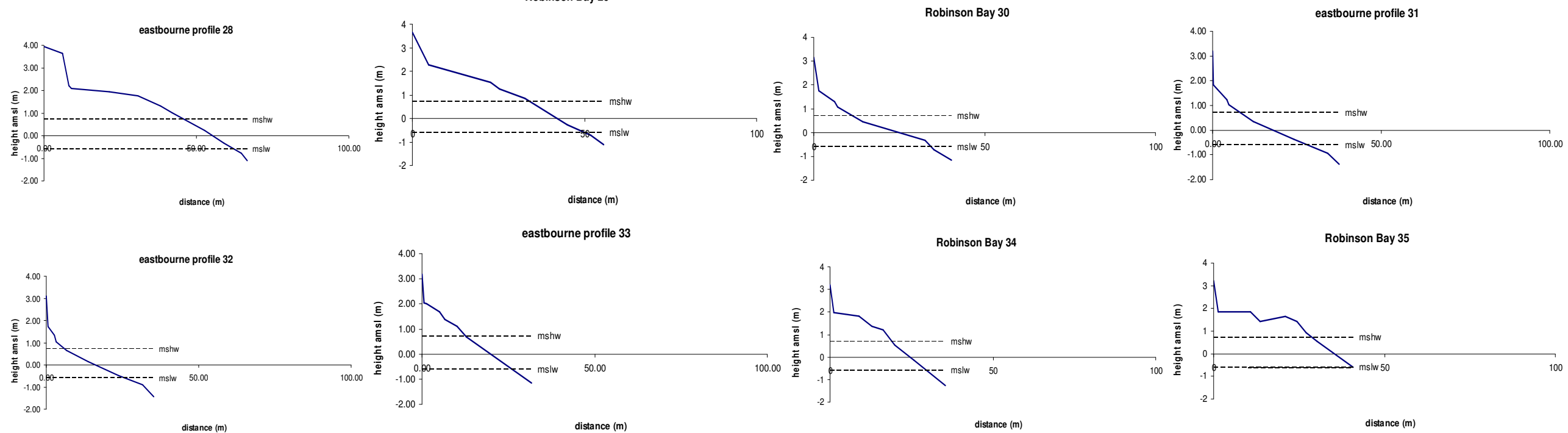

Robinson Bay 36

Robinson Bay 37
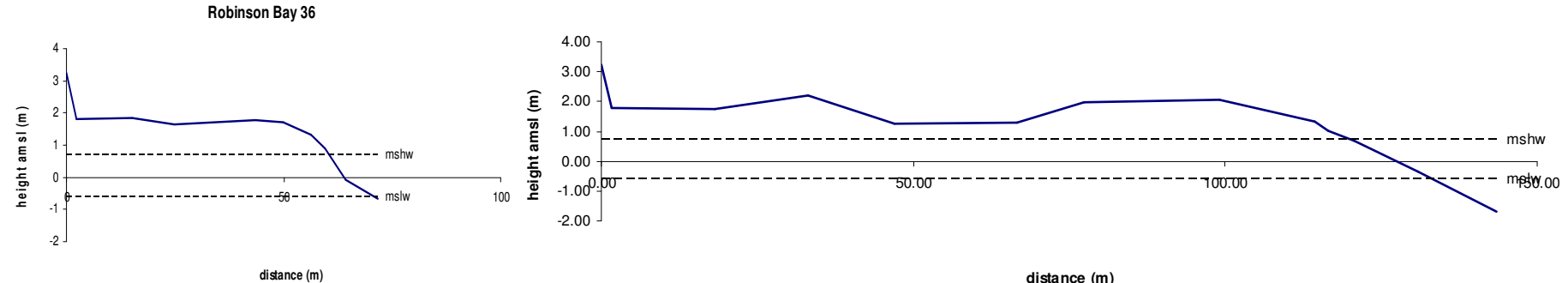

Robinson Bay 38

Robinson Bay 39

Robinson Bay 40
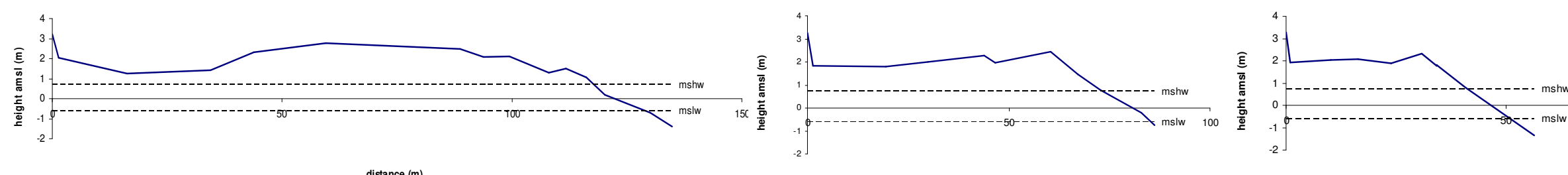


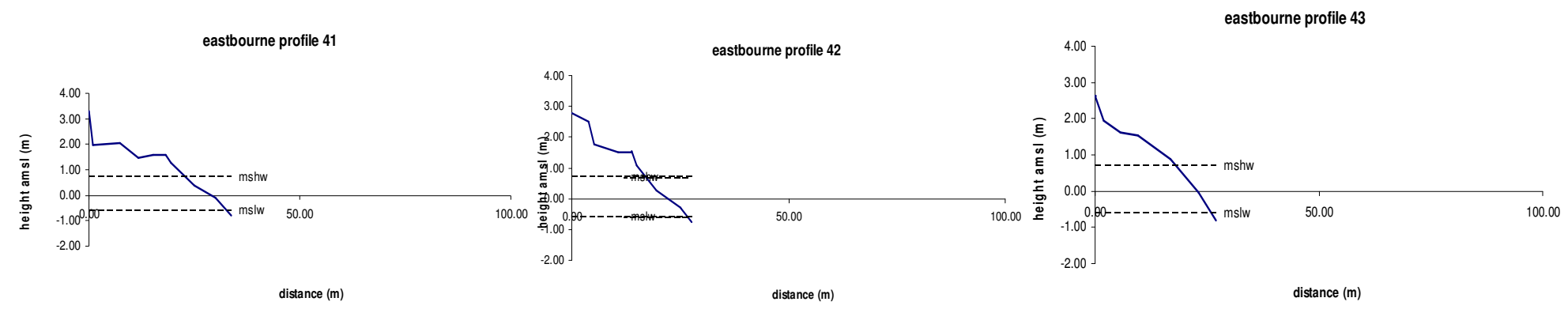

Surveyed Profiles Burdans Gate
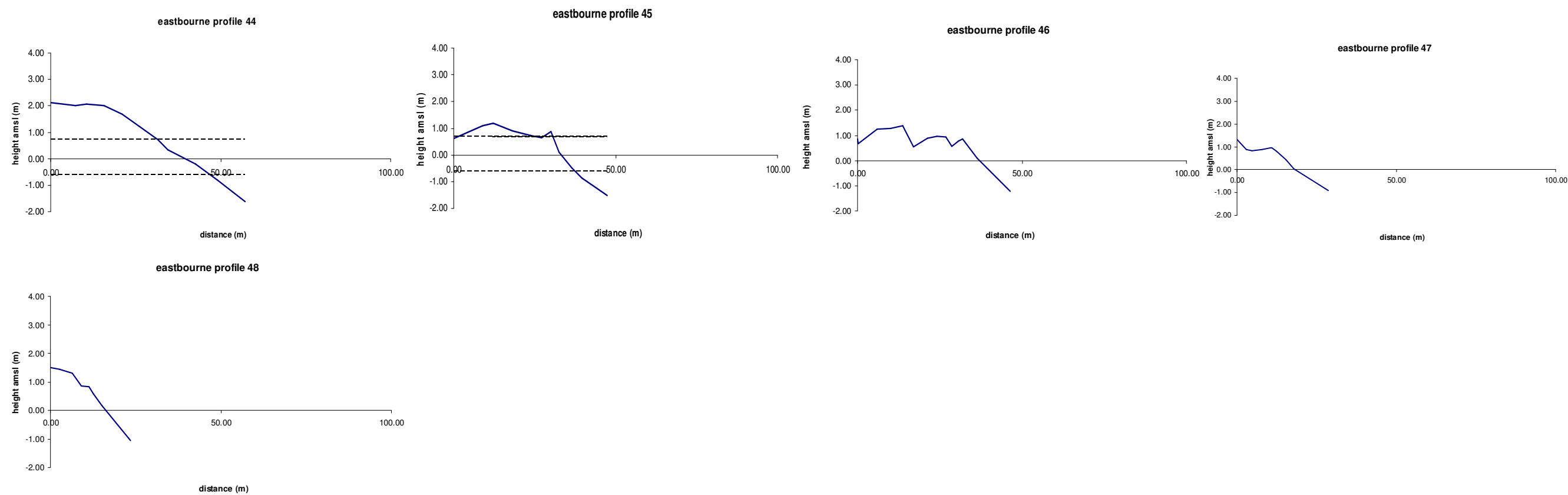
Repeat surveys Robinson Bay
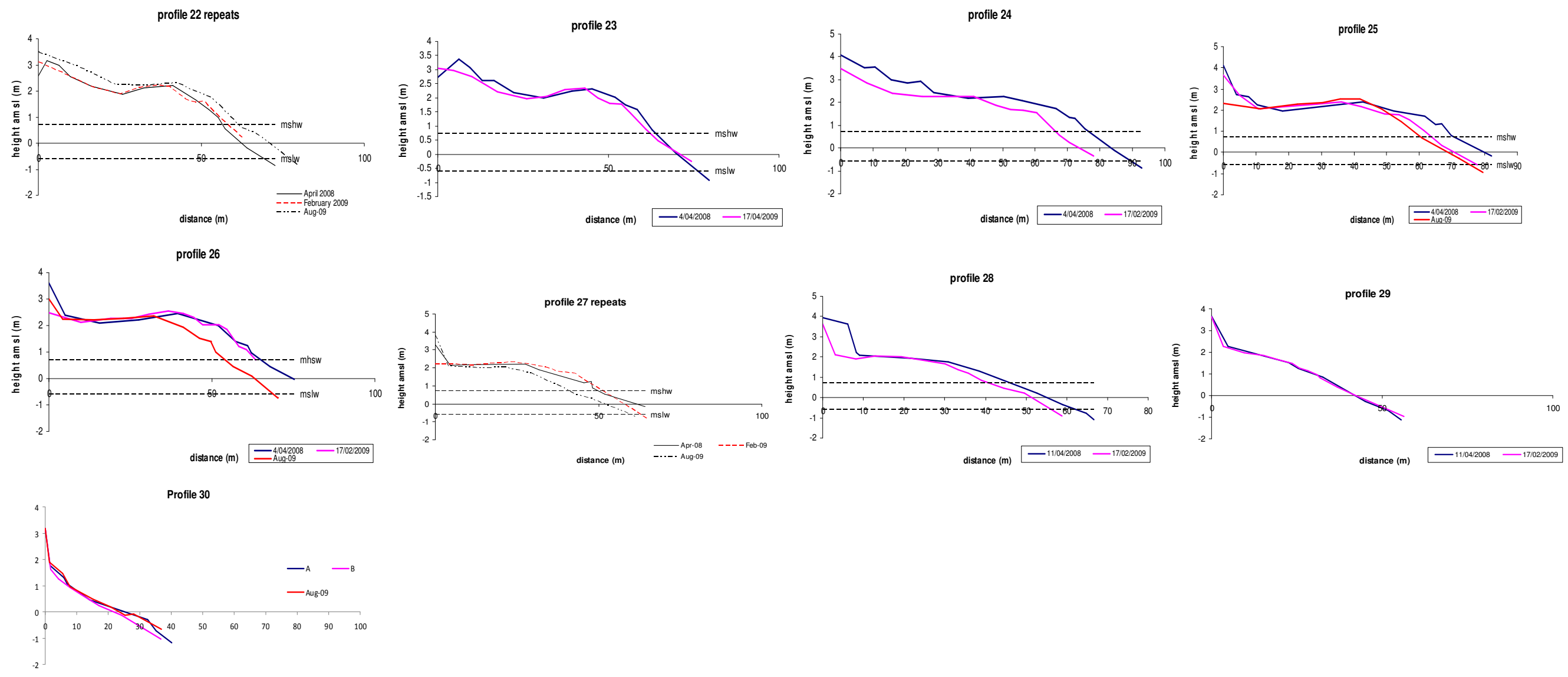
Raw Survey Data: Eastbourne Profiles 1-43.

\begin{tabular}{|c|c|c|c|c|c|c|c|c|c|c|c|c|c|c|c|c|c|}
\hline profile & length & height & sope ra & angle de & eachfa & profile & length & height & slope rad & angle deb & bachfal & profile & length & height & slope rad & angle deg & beachfac \\
\hline 1 & 0.00 & 1.23 & & & & 2 & 0.00 & 1.46 & & & & 3 & 000 & 260 & & & \\
\hline \multirow[t]{8}{*}{ ㅂoblsuln'3pur'1 } & 1.72 & 0.81 & 0.24 & 14.01 & 820 & 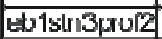 & 2.21 & 1.33 & 0.06 & 346 & 8.95 & 비 Mrisprús & 6.12 & 1.49 & 0.06 & 4.78 & \\
\hline & 267 & 060 & 0.12 & 7.09 & & & 3.64 & 0.00 & 0.37 & $21 \_18$ & & & 11.06 & DE2 & 0.17 & 10.01 & \\
\hline & 3.98 & 0.36 & 0.26 & 14.69 & & & 6.13 & 0.46 & D.14 & 7.97 & & & 14.72 & 0.54 & 0,02 & 1.28 & 5.61 \\
\hline & 6.91 & 0.21 & 0.05 & 281 & & & 8.02 & 0.30 & 0.00 & 4.66 & & & 17.02 & 0.46 & 0.04 & 2.09 & \\
\hline & 10.32 & -0.25 & 0.13 & 7.72 & & & 10.22 & -0.09 & 0.18 & 10_33 & & & 18.03 & 0.26 & 0.19 & 11.08 & \\
\hline & 13.44 & -6.65 & 0.13 & 7.32 & & & 14.24 & -0.52 & o.11 & 607 & & & 21.27 & -0.15 & b.13 & 7.28 & \\
\hline & 16.92 & -1.01 & 0.10 & 690 & & & 19.27 & $-1, \infty$ & 0.10 & GD1 & & & 27.20 & $-0,01$ & 0,00 & 4.33 & \\
\hline & 2205 & -1.54 & 0.10 & 5.97 & & & 24.13 & -1.50 & 0.11 & 6.41 & & & 3222 & -1.03 & 0.00 & 4.91 & \\
\hline \multirow[t]{2}{*}{ average } & & & & & & & & & D.14 & 2.26 & & & 36.67 & -1.67 & D.14 & 8.30 & \\
\hline & & & & & & & & & & & & & & & 0.10 & 6.01 & \\
\hline profile & length & height & Iope ra & angle de & eachfar & profile & length & height & sope rad & angle deb & machta & profile & length & height & slope rad & angle deg & beachfac \\
\hline 4 & 0.00 & 1.61 & & & & 5 & 0.00 & 291 & & & & 6 & 0,00 & 1.60 & & & \\
\hline \multirow{11}{*}{ eblstn2prof 1} & 4.70 & 1.52 & 0.02 & 1.10 & & Eb 1stn2prof & 10.04 & 272 & 0.02 & 1.13 & & eb1str2prof3 & 15.27 & 0.82 & 002 & 0.99 & \\
\hline & 8.10 & 0.56 & 0.17 & 962 & 6.31 & & 19.00 & 223 & 0.06 & 3.12 & & & 25.52 & 0.65 & 0.02 & 0.98 & \\
\hline & $11 / 43$ & 0.77 & 0.05 & 3.06 & & & 25.52 & 1.90 & 0.06 & 285 & & & 32.80 & 0.40 & 0.00 & 1.93 & 3.86 \\
\hline & 14.98 & 0.57 & 0.06 & 3.18 & & & 31.51 & 1.72 & 0.08 & 1.74 & & & 33.93 & 0.22 & 0.16 & 9.41 & \\
\hline & 16.04 & 0.35 & 0.20 & 11.68 & & & 35.63 & 1.22 & 0.12 & 6.53 & & & 38.81 & -0.34 & 0.12 & 6.59 & \\
\hline & 18.00 & 0.06 & 0.15 & 860 & & & 39.34 & 0.91 & 0.09 & A.88 & 6.02 & & 45.42 & -0.66 & 0.06 & 270 & \\
\hline & 22.61 & -0.44 & D.11 & 6.22 & & & 43.41 & 0.71 & 006 & 273 & & & 51.62 & -1.15 & 000 & 4.42 & \\
\hline & 26.13 & -0.68 & 0.07 & 3.85 & & & 45.25 & 0.40 & 0.17 & 988 & & & & & 0.07 & 3.86 & \\
\hline & 28.58 & -0.87 & 0.08 & 4.39 & & & 47.21 & 0.06 & 0.17 & 9.71 & & & & & & & \\
\hline & & & & & & & 61.73 & -1.13 & 0.08 & 4.59 & & & & & & & \\
\hline & & & & & & & & & 0,00 & $4.7 \mathrm{G}$ & & & & & & & \\
\hline profile & length & height & tope ra & angle de & & profile & length & height & sope rad & angle deb & sachfa & profile & length & height & slope rad & angle deg & beachfac \\
\hline 7 & 0.00 & 202 & & & & 8 & 0.00 & 1.73 & & & & 9 & 0.00 & 248 & & & \\
\hline \multirow[t]{13}{*}{ eblstn 1prof 1} & 3.97 & 265 & -0.16 & -9.20 & \multicolumn{2}{|r|}{ eastbstnGorof } & 11.84 & 1.67 & 0,00 & 0.25 & & eastbstn6rof 2 & 8.44 & 210 & 0.04 & 2.56 & 7.47 \\
\hline & 8.91 & 253 & 0.03 & 1.47 & & & 3006 & 1.49 & 0.01 & 0.58 & & & 13.65 & 1.15 & 0.18 & 10.44 & \\
\hline & 13.91 & 1.77 & 0.15 & 8.61 & & & 33.87 & 1.42 & 0.02 & 0.97 & 7.24 & & 21.93 & 1.66 & -0.06 & -3.50 & \\
\hline & 33.40 & 1.50 & 0.01 & 0.81 & & & 36.45 & 0.87 & 0.22 & 12.39 & & & 25.59 & 0.84 & 0.22 & 12.84 & \\
\hline & 35.13 & 1.16 & 0.19 & 11.10 & 9.12 & & 38.92 & 0.61 & 0.10 & 5.56 & & & 28.78 & 0.54 & 010 & 5.46 & \\
\hline & 38.06 & 1.00 & 0.04 & 256 & & & 42.54 & 0.27 & 0.09 & 5.33 & & & 43.26 & -0.82 & 0.00 & 5.37 & \\
\hline & 39.28 & 0.84 & 0.16 & 8.97 & & & 61.50 & -1.47 & 0.09 & 5.28 & & & 49.44 & -1.49 & 0.11 & 6.19 & \\
\hline & 39.78 & 0.59 & 0.50 & 28.78 & & & & & 0.08 & 4.40 & & & & & 0.10 & 5.62 & \\
\hline & 42.21 & 0.21 & D.16 & 900 & & & & & & & & & & & & & \\
\hline & 46.16 & -0.20 & 0.10 & 5.78 & & & & & & & & & & & & & \\
\hline & 51.32 & -0.42 & 0.04 & 255 & & & & & & & & & & & & & \\
\hline & 58.17 & -0.98 & 0.07 & 4.24 & & & & & & & & & & & & & \\
\hline & & & & & & & & & & & & & & & & & \\
\hline
\end{tabular}




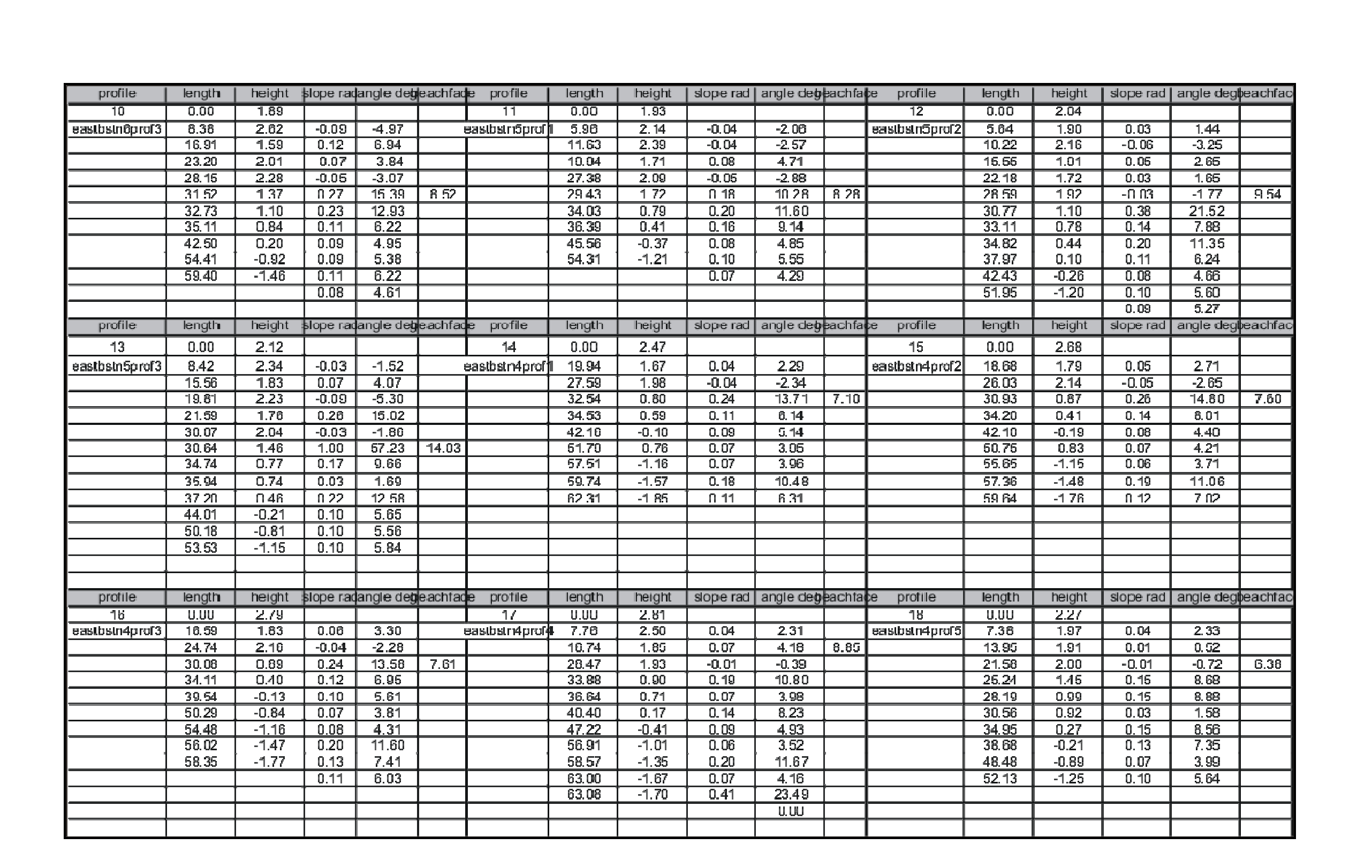




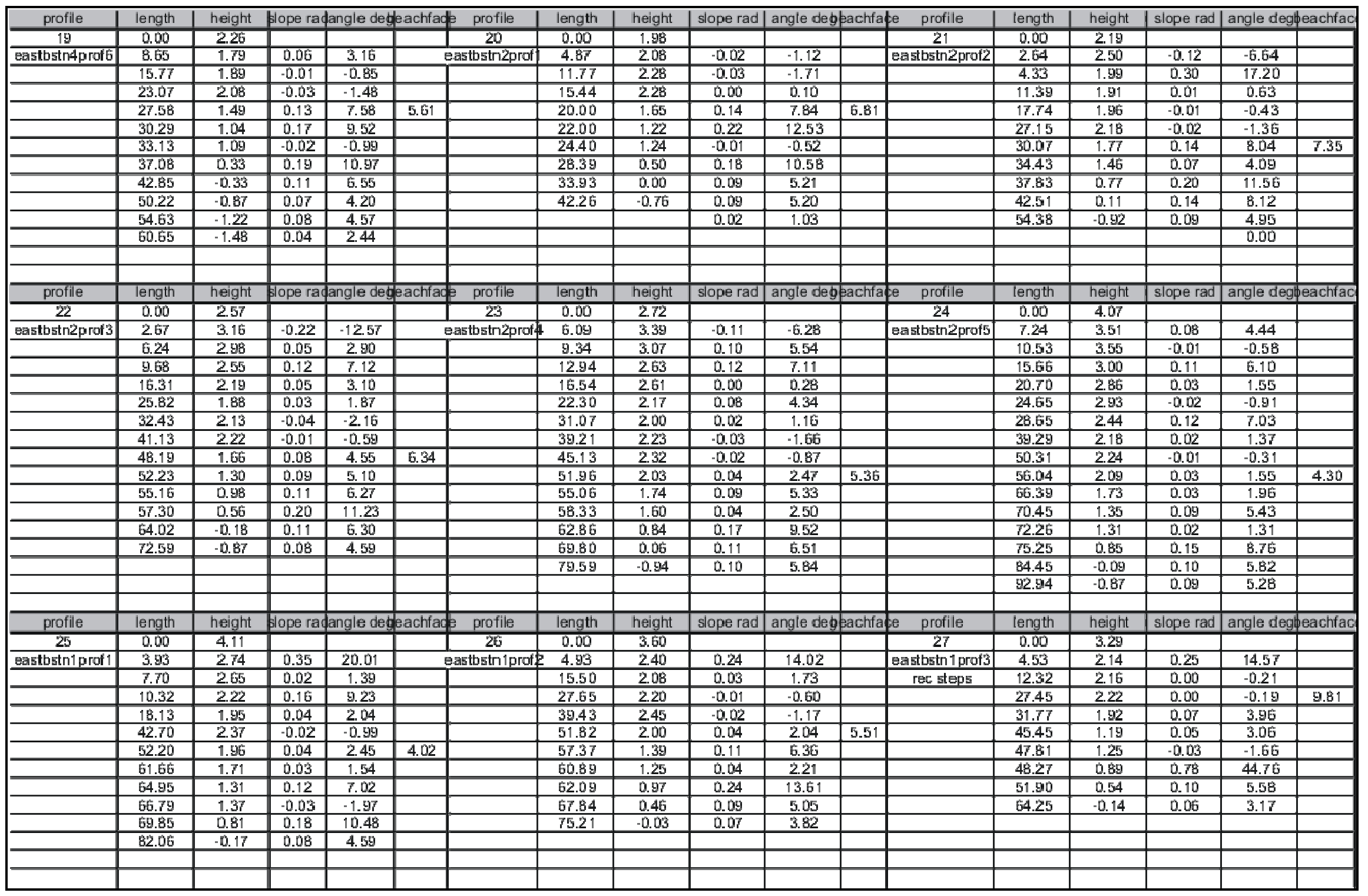




\begin{tabular}{|c|c|c|c|c|c|c|c|c|c|c|c|c|c|c|c|c|c|}
\hline profile & length & height & Hopera & Atangle det & eactia & profile & length & height & slope rad & | angle deg & pactfal & profile & length & height & slope rad & | angle deg| & foreshar \\
\hline 28 & 0.00 & 3.95 & & & & \begin{tabular}{|l|}
29 \\
\end{tabular} & 0.00 & 368 & & & & \begin{tabular}{|l|}
30 \\
\end{tabular} & $0, \infty$ & 3.17 & & & \\
\hline \multirow[t]{11}{*}{ eastostingroul } & 6.11 & 363 & 0.05 & 299 & & eastbstn3prot & 4.70 & $2 \pi]$ & 0.30 & 17.14 & & eastbosin3po/3 & 1.51 & 1.75 & 094 & 53.82 & \\
\hline & 8.30 & 222 & 0.64 & 36.90 & & & 22.67 & 1.51 & 0.04 & 241 & \multicolumn{2}{|c|}{ temp bm Sea wall } & 6.05 & 1.31 & 0.10 & 5.56 & 6.97 \\
\hline & 899 & 200 & 0.19 & 10.77 & & & 25.42 & 1.26 & 0,09 & 539 & 4.72 & & 6.95 & 1.07 & 0.26 & 14.95 & \\
\hline & 21.46 & 1.93 & 0.01 & 0.71 & & & 3263 & 0.86 & 0.05 & 312 & & & 14.29 & 046 & 0,08 & 4.76 & \\
\hline & 30.82 & 1.75 & 0.02 & 1.12 & & & 45.06 & -0.28 & 0.00 & 57 & & & 32.52 & -0.31 & 004 & 242 & \\
\hline & 38.38 & 1.31 & 0.06 & 334 & 5.22 & & 51.70 & -071 & 007 & 373 & & & 35.19 & -073 & 0.16 & 9.10 & \\
\hline & 42.20 & $1 . \bar{Q}$ & 0.08 & 4.40 & & & 55.59 & -1.13 & 0.11 & 6.11 & & & 40.23 & -1.17 & 000 & 500 & \\
\hline & 59.03 & -0.34 & 0.09 & 5.04 & & & & & & & & & & & & & \\
\hline & 64.78 & -0.78 & 0.08 & 4.36 & & & & & & & & & & & & & \\
\hline & 66.68 & -1.10 & 0.17 & 984 & & & & & & & & & & & & & \\
\hline & & & & & & & & & & & & & & & & & \\
\hline prófile & length & height & 其opé га & tenglé des & oreshă & profilé & length & height & sope rad & angle deg & presha & profile & length & héight & slope rad & anglè dèg & jeactrac \\
\hline 31 & 0.00 & 3.19 & & & & 32 & 0.00 & 312 & & & & 33 & $0 . \infty$ & 3.17 & & & \\
\hline gastbstri3prof4 & 0.27 & 1.83 & 5.01 & 287.26 & & exstbstn3prale & 0.56 & 1.73 & 254 & 145.58 & & do2sjuneprofl 1 & 0,6 & 203 & 1.75 & 10046 & \\
\hline & 4.21 & 1.24 & 0.15 & 856 & 7.55 & & 2.67 & 1.33 & 0.19 & 10.69 & 8.57 & & 1.30 & 202 & OCQ & 0.91 & 5.88 \\
\hline & 4.88 & 1.02 & 0.32 & 1847 & & & 3.35 & 1.05 & 0.41 & 23.32 & & & 5.05 & 1.66 & 0,09 & 5.40 & \\
\hline & 24.19 & -0.38 & 0.06 & 346 & & & 13.75 & 0.16 & 0.07 & 4.06 & & & 10.12 & 1.11 & 0.08 & 4.66 & \\
\hline & 34.14 & .093 & 0.06 & 315 & & & 23.78 & -0.47 & 0.06 & 359 & & & 12.85 & 0.67 & 0.16 & 9.17 & \\
\hline & 37.59 & -1.37 & 0.13 & 7.35 & & & 31.63 & -091 & 006 & 323 & & & 31.79 & -1.16 & 0.10 & 5.55 & \\
\hline & & & & & & & 35.20 & -1.43 & 0.15 & 845 & & & & & & & \\
\hline & & & & & & & & & & & & & & & & & \\
\hline profile & length & height & Sopera & tangle det & eactía & profile & length & height & sope rad & angle deb & pactfal & profile & length & height & slope rad & angle degt & beactfao \\
\hline 34 & 000 & 318 & & & & 35 & 0.00 & 322 & & & & 36 & 000 & 323 & & & \\
\hline étr25urievoll2 & 1.11 & 1.99 & 1.07 & 61.50 & & éb06auguprof & 1.30 & 1.84 & 1.06 & 60.96 & & dboGauguprula & 233 & 1.82 & 0.61 & 34.86 & \\
\hline & 8.83 & 1.83 & 0.02 & 1.20 & 659 & & 10.72 & 1.86 & 0.00 & -0.12 & & & 15.15 & 1.86 & 0.00 & -0.18 & \\
\hline & 12.87 & 1.37 & 0.11 & 6.57 & & & 13.69 & 1.42 & 0.15 & 848 & 5.71 & & 24.82 & 1.64 & 0,02 & 1.30 & \\
\hline & 16.21 & 1.20 & 0.05 & 277 & & & 21.00 & 1.64 & -0.03 & -1.78 & & & 43.46 & 1.79 & -0.01 & -0.47 & \\
\hline & 19.83 & 0.56 & 0.18 & 10.37 & & & 24.36 & 1.44 & 006 & 347 & & & 49.92 & 1.73 & 001 & 0.54 & \\
\hline & 25.67 & -0.14 & 0.12 & 6.71 & & & 26.99 & 0.94 & 0.19 & 11.01 & & & 56.29 & 1.34 & 0,06 & 3.52 & 6.84 \\
\hline & 35.39 & -1.25 & 0.11 & 6.56 & & & 30.25 & 0.54 & 0.12 & 689 & & & 59.48 & 0.91 & 0.13 & 7.67 & \\
\hline & & & & & & & 40.74 & -059 & 0.11 & 6.17 & & & 64.34 & -0.08 & 0.20 & 11.67 & \\
\hline & & & & & & & & & & & & & 71.65 & -065 & 0,08 & 4.50 & \\
\hline & & & & & & & & & & & & & & & & & \\
\hline
\end{tabular}




\begin{tabular}{|c|c|c|c|c|c|c|c|c|c|c|c|c|c|c|c|c|c|}
\hline profile & length & height & Hope raф & angle deb & eachfad: & profile & length & height & s lope rad & angle deb & pactfak & profile & length & height & slope rad & | angle degl| & beactfac \\
\hline 37 & 0.00 & 3.23 & & & & 38 & 0.00 & 322 & & & & 39 & 0.00 & 3.27 & & & \\
\hline \multirow[t]{13}{*}{ eb06auguprof 3} & 1.62 & 1.77 & 0.90 & 51.75 & \multicolumn{2}{|r|}{ eb66auguproff } & 1.43 & 206 & 0.81 & 46.67 & & Bbo6auguprof & 1.33 & 1.83 & 1.08 & 61.83 & \\
\hline & 18.26 & 1.73 & 0.00 & 0.14 & & & 16.33 & 1.26 & 0.05 & 306 & & & 19.49 & 1.80 & 0.00 & 0.09 & \\
\hline & 33.21 & 221 & -0.03 & -1.86 & & & 34.40 & 1.42 & -0.01 & -0.50 & & & 29.99 & 200 & -0.02 & -1.08 & \\
\hline & 66.54 & 1.27 & 0.00 & -0.02 & & & 59.44 & $2 \pi$ & -0.03 & -1.62 & & & 46.51 & 1.97 & 0.12 & 6.80 & \\
\hline & 7.42 & 1.97 & -0.06 & -3.67 & & & 88.76 & 250 & 0.01 & 0.51 & & & 60.44 & 243 & -0.03 & -1.90 & \\
\hline & 99.09 & $20 B$ & 0.00 & -0.17 & & & 93.76 & 210 & 0.08 & 4.66 & 4.66 & & 67.15 & 1.46 & 0.15 & 8.33 & 7.57 \\
\hline & 114.40 & 1.31 & 0.05 & 270 & 545 & & 99.36 & 214 & -0.01 & -0.46 & & & 72.83 & 0.79 & 0.12 & 6.74 & \\
\hline & 120.76 & 0.67 & 0.08 & 460 & & & 111.62 & 1.53 & -0.07 & -375 & & & 86.20 & -076 & 0.17 & 9.52 & \\
\hline & 130.89 & -0.36 & 0.10 & 585 & & & $116 \_16$ & 1.08 & 0.10 & 560 & & & & & & & \\
\hline & 143.44 & -1.60 & 0.11 & 6.04 & & & 120.15 & 0.21 & 0.22 & 12.38 & & & & & & & \\
\hline & & & & & & & 129.98 & -0.71 & 0.09 & 5.37 & & & & & & & \\
\hline & & & & & & & 134.89 & -1.38 & 0.14 & 7.80 & & & & & & & \\
\hline & & & & & & & & & & & & & & & & & \\
\hline profile & length & height & tope rad & Engle deb & eachfad & profile & length & height & slope rad & angle deb & bachfa: & be profile & length & height & slope rad & angle deg. & beachfac \\
\hline 40 & 0.00 & 326 & & & & 41 & 0.00 & 330 & & & & 42 & 0.00 & 279 & & & \\
\hline eb19septprof1 & 089 & 1.94 & 1.49 & 8514 & & eb19septprof & 1.06 & 1.56 & 1.23 & 70.67 & & eb19septprof3 & 3.79 & 252 & 0.07 & 4.14 & \\
\hline & 23.82 & 1.88 & 0.03 & 1.44 & & & 15.36 & 1.59 & $-0.0 B$ & -1.76 & & & 13.76 & 1.53 & -0.01 & -0.48 & \\
\hline & 30.76 & 231 & -0.06 & -350 & & & 18.22 & 1.58 & 0.00 & 0.16 & 8.16 & & 13.77 & 1.53 & -0.10 & -5.99 & \\
\hline & 34.20 & 1.77 & 0.16 & 9.06 & 862 & & 19.41 & 1.26 & 0.27 & 15.23 & & & 14.89 & 1.07 & 0.41 & 23.33 & 11.14 \\
\hline & 34.25 & 1.82 & -1.08 & -61.99 & & & 24.90 & 0.36 & 0.16 & 9.42 & & & 19.51 & 0.28 & 0.17 & 9.86 & \\
\hline & 40.79 & 0.81 & 0.15 & 8.85 & & & 29.88 & -0.07 & 0.00 & 500 & & & 25.12 & -0.30 & 0.10 & 5.95 & \\
\hline & 56.39 & -1.35 & 0.14 & 7.94 & & & 33.71 & -0.81 & 0.19 & 11.00 & & & 25.19 & -0.31 & 0.10 & 6.00 & \\
\hline & & & & & & & & & & & & & 27.56 & -0.75 & 0.18 & 10.57 & \\
\hline & & & & & & & & & & & & & & & & & \\
\hline & & & & & & & & & & & & & & & & & \\
\hline profile & length & height & tope rad & angle deb & eachfad & profile & length & height & slope rad & angle deb & pachfa & profile & length & height & slope rad & angle deg & eachfac \\
\hline 43 & 0.00 & 263 & & & & & & & & & & & & & & & \\
\hline eb19septprof 4 & 0.06 & 265 & -0.34 & -19.53 & & & & & & & & & & & & & \\
\hline & 1.87 & 1.96 & 0.38 & 21.81 & & & & & & & & & & & & & \\
\hline & 5.65 & 1.62 & 0.09 & 5.09 & & & & & & & & & & & & & \\
\hline & 9.65 & 1.53 & 0.02 & 1.23 & 653 & & & & & & & & & & & & \\
\hline & 16.81 & 0.89 & 0.09 & 5.16 & & & & & & & & & & & & & \\
\hline & 23.05 & -0.04 & 0.15 & 8.54 & & & & & & & & & & & & & \\
\hline & 27.01 & -0.82 & 0.20 & 11.18 & & & & & & & & & & & & & \\
\hline & & & & & & & & & & & & & & & & & \\
\hline
\end{tabular}


Appendix 2: Aerial Photo Analysis 
Aerial photo analysis data

\begin{tabular}{|c|c|c|c|c|c|c|c|c|c|c|c|c|c|c|c|c|}
\hline & & \multicolumn{6}{|c|}{ Shoreline wicth meas.red fom arials } & & \multirow[t]{2}{*}{ surveyed } & \multirow[t]{2}{*}{ distenos } & \multirow{2}{*}{\multicolumn{2}{|c|}{ per entayment|cumlatve }} & \multicolumn{4}{|c|}{ Shordine width dhange between pho } \\
\hline Location & profile & 2008 & 2001 & 1986 & 1975 & 1969 & 1954 & 1941 & & & & & $1941-1954$ & 9541969 & $1969-1975$ & $1975-1986$ \\
\hline Days Bay & 1 & 17.78 & 1318 & 2615 & $294 \mathrm{~s}$ & 252 & 21.78 & 1696 & 11.C5 & 104 & 104 & 104 & 4.32 & 3.44 & 4.27 & -334 \\
\hline & 2 & 21.71 & 1637 & 2692 & 31.04 & $27.0 \mathrm{E}$ & 283 & 1851 & 13.86 & 27 & 131 & 131 & 432 & 4.19 & 4.00 & 412 \\
\hline & 3 & 237 & 1993 & 2902 & 345 & 287 & 27.57 & 26.1 & 2297 & 36 & 167 & 167 & 1.47 & 1.2 & 5.75 & -5.5 \\
\hline & 4 & 27.5 & 17.9 & 2867 & 3037 & 322 & 3544 & 33.51 & $21 . \mathrm{CB}$ & 53 & 20 & 220 & 1.93 & -3.18 & -1.89 & -1.7 \\
\hline & 5 & 2635 & 17.11 & 2486 & 330 & 27.66 & 3233 & 2659 & 13.04 & 68 & 288 & 288 & 574 & -4.47 & 5.17 & -817 \\
\hline & 6 & 21.18 & 21.47 & 1879 & 242 & 24.21 & 2821 & 2298 & 15.82 & 32 & 320 & 320 & 523 & -4 & 0.01 & -543 \\
\hline & 7 & 1908 & 1638 & 1806 & 1980 & 1941 & 21.78 & 2099 & 1323 & 69 & 389 & 369 & 0.79 & -237 & 0.42 & -1.77 \\
\hline & 8 & 308 & 27.3 & 3059 & 2886 & 285 & 3391 & 34.7 & 35.08 & 50 & 459 & 439 & -0.79 & -5.36 & 0.3 & 1.74 \\
\hline & 9 & 37.45 & 31.35 & 3848 & 37.2 & 3505 & 43.88 & 39.63 & 36.09 & 40 & 479 & 479 & 4.25 & -8.83 & 217 & 1.26 \\
\hline & 10 & 354 & 24.79 & 34.9 & $294 \mathrm{C}$ & 27.48 & 39.22 & 2979 & 23.25 & 46 & 525 & 525 & 943 & -11.74 & 201 & 541 \\
\hline & 11 & 2613 & 2073 & 2426 & $247 \mathrm{c}$ & 253 & 3308 & 27.9 & 29.88 & 55 & 580 & 580 & 518 & -7.72 & -0.64 & -046 \\
\hline & 12 & 2261 & 1696 & 20.1 & 21.06 & 2291 & 31.46 & 27.54 & 24.93 & 25 & 605 & 605 & 392 & -855 & -1.86 & -0.95 \\
\hline & 13 & 229 & 1641 & 17.88 & 1618 & 2018 & 27.67 & 2708 & 21.92 & 55 & 660 & 660 & 0.59 & -7.49 & 4 & 1.7 \\
\hline & 14 & 2264 & 17.51 & 17.55 & 1934 & 2001 & 27.54 & 2499 & 23.59 & 44 & 704 & 704 & 255 & -7.53 & $=0.67$ & -1.79 \\
\hline & & & & & & & & & & & & 704 & & & & \\
\hline Fona Bay & 1 & 1831 & 17.68 & 3691 & 2627 & 355 & 21.04 & 1274 & 8.47 & 61 & 61 & 765 & 83 & 14.56 & -9.32 & 1064 \\
\hline & 2 & 2248 & 1841 & 31.89 & 2374 & 31.04 & 1227 & 545 & 9.72 & 31 & 9 & 796 & 6.32 & 1877 & -73 & 815 \\
\hline & 3 & 2421 & 1917 & 3211 & 21.44 & 2912 & 122 & 49 & 23.08 & 77 & 169 & 873 & 7.3 & 169 & $=7.69$ & 1067 \\
\hline & 4 & 2831 & 1616 & 27.31 & 2007 & 2371 & 6.24 & -10.96 & 13.55 & 121 & 290 & 994 & 17.2 & 17.47 & -3.64 & 7.24 \\
\hline & 5 & 337 & 2277 & 3062 & 233 & 2657 & 306 & -1296 & 47.82 & 92 & 382 & 1086 & 1602 & 2351 & -3.21 & 7.26 \\
\hline & 6 & 34.9 & 2563 & 3319 & 2684 & 2587 & 568 & $-9.6 \mathrm{~S}$ & 3581 & 60 & 42 & 1146 & 15.37 & 2019 & 0.97 & 635 \\
\hline & 7 & 482 & 41.51 & 4273 & 433 & 468 & 21.74 & -6.23 & 44.25 & 52 & 494 & 1198 & 27.97 & 2515 & -3.57 & -059 \\
\hline & 8 & 327 & 21.34 & 2695 & 2606 & 1842 & 312 & -6.88 & 45.50 & 82 & $5 / 6$ & 1280 & 10 & 153 & 7.64 & 089 \\
\hline & 9 & 2664 & 21.75 & 3006 & 2626 & 1687 & 346 & -11.15 & 34.50 & 85 & 661 & 1365 & 14.61 & 1341 & 9.39 & 38 \\
\hline & 10 & 3243 & 229 & 33.17 & 2941 & 3036 & 834 & 4.42 & 44.64 & 72 & 733 & 1437 & 392 & $220 k$ & -0.96 & 376 \\
\hline & 11 & 255 & 21.0 & 31.79 & 308 & 3271 & 1316 & 278 & 41.23 & 41 & 774 & 1478 & 10.38 & 1956 & -1.91 & 099 \\
\hline & 12 & $27 . \%$ & 2376 & 31.98 & 332 & 34.2 & 168 & 124 & 33.18 & 34 & 808 & 1512 & 15.6 & 17.3 & -1 & -1.25 \\
\hline & 13 & 2835 & 2645 & 30.8 & 3516 & 3645 & 17221 & 0.95 & 41.86 & 32 & 800 & 1544 & 16.26 & 1924 & -1.29 & -436 \\
\hline & 14 & 31.6 & 250 & 3379 & 41.64 & 37.97 & 21.1 & 648 & 41.67 & 47 & 887 & 1391 & $14.6 e^{2}$ & 1687 & 3.67 & -7.86 \\
\hline & 15 & $31.5 E$ & 2806 & 34.19 & 349 & 37.2 & 21.61 & 854 & 39.57 & 29 & 916 & 1620 & 13.07 & 1561 & -2.23 & $=0.8$ \\
\hline & 16 & 3434 & 2558 & 41.59 & 3596 & 4056 & 26.27 & 901 & 38.22 & 47 & 963 & 1667 & 17.26 & 1428 & 4.59 & 563 \\
\hline & 17 & 3224 & 355 & 4079 & $33 \pi$ & 403 & 23.63 & 1243 & 4241 & 41 & 1004 & 1708 & 11.2 & 167 & -6.56 & 701 \\
\hline & 18 & 36.6 & 34.62 & 41.57 & 3657 & 37.76 & 2661 & 9.73 & 37.04 & 27 & 1081 & 1735 & 16.88 & 11.15 & -1.19 & 5 \\
\hline & 19 & 368 & 3898 & 45.28 & 37.14 & 37.14 & 2677 & 1008 & 33.55 & 41 & $10 / 2$ & 1776 & 16.69 & 1037 & 0 & 814 \\
\hline
\end{tabular}




\begin{tabular}{|c|c|c|c|c|c|c|c|c|c|c|c|c|c|c|c|c|}
\hline Rotinson & 20 & 61.97 & 56.17 & 47.15 & 47.99 & 39.57 & 38.69 & $11 .: 1$ & 33.91 & 62 & 62 & 1838 & 27.58 & 0.38 & 8.42 & -0.84 \\
\hline & $2^{*}$ & 67.23 & 65.04 & 50.33 & AED & 45.51 & 38.16 & 9.13 & 43.73 & 36 & 98 & 1874 & 20.03 & 7.35 & 0.53 & 4.29 \\
\hline & 22 & 73.75 & 72.32 & 49 & 47.84 & 46.48 & 37.86 & 12.63 & 62.33 & 40 & $13 E$ & 1914 & 25.23 & 8.52 & $1.3 E$ & 1.16 \\
\hline & 23 & 77.59 & 76.11 & 55.83 & 4981 & 50.33 & 36.47 & 14.09 & 70.35 & 32 & 17[ & 1946 & 22.36 & 1386 & -0.52 & 6.02 \\
\hline & 24 & 78.4 & 60.88 & 40.85 & 4828 & 47.01 & 41.06 & 16.30 & 03.63 & 40 & $21 \mathrm{C}$ & 1005 & 25.67 & 5.35 & 1.27 & 1.67 \\
\hline & 25 & 73.44 & 68.32 & 30.97 & 3973 & 35.18 & 52.37 & 20.82 & 79.93 & 57 & $27 \mathrm{E}$ & 2052 & 31.55 & -17.19 & $4.5 E$ & -8.76 \\
\hline & 26 & 63.62 & 59.19 & 26.82 & 3066 & 27.07 & 49.59 & 26.84 & 74.75 & 42 & $31 E$ & 2094 & 22.75 & -22.52 & $3.5 \mathrm{I}$ & -384 \\
\hline & 27 & 56.54 & 48.15 & 21.34 & 1080 & 25.76 & 40.77 & $33 .{ }^{2} 8$ & 61.67 & 38 & $35 E$ & 2132 & B6.50 & 24.01 & 5.87 & 1.45 \\
\hline & 26 & 44.57 & 39.22 & 28.37 & 14.98 & 25.52 & 43.59 & 33.64 & 55.19 & 38 & 394 & 2170 & 395 & $-1 E .07$ & -10.54 & $1=39$ \\
\hline & 29 & 27.88 & 22.66 & 19.54 & 7.72 & 19.63 & 32.48 & 27.78 & 42.03 & 35 & 425 & 2205 & 4.7 & -12.85 & -11.91 & 11.82 \\
\hline & 30 & 23.60 & 18.06 & 10.63 & 5.00 & 16.00 & 24.00 & 24.60 & 23.77 & 13 & 442 & 2218 & 0.3 & 8 & 11 & 4.54 \\
\hline & $3^{\prime}$ & 30.2 & 21.24 & 15.78 & 82 & 15.74 & 14.78 & 17 & 17.61 & 52 & 494 & 2270 & -2.22 & 0.36 & -7.54 & 7.58 \\
\hline & 32 & 29.95 & 21.6 & 18.26 & 9.16 & 8.35 & 13.9 & $20 . * 1$ & 17.34 & 70 & 564 & 2340 & -6.21 & -5.55 & 0.81 & 5.1 \\
\hline & 33 & 35.17 & 26.00 & 20.03 & 6.83 & 6.42 & 11.64 & 14.30 & 10.13 & 83 & 647 & 2423 & $2.7 E$ & 5.22 & 0.41 & 22.2 \\
\hline & 34 & 36.38 & 19.25 & 24.7 & 17 & 18.41 & 14.82 & 12.7 & $23.4 \mathrm{~J}$ & 76 & $72 \mathrm{z}$ & 2499 & 2.65 & 3.59 & -1.41 & 7.7 \\
\hline & 35 & 36.84 & 17.24 & 20.6 & 1584 & 17.93 & 13.05 & 11.57 & $34.0]$ & 75 & $79 E$ & 2574 & 1.48 & 4.38 & -2.09 & 4.76 \\
\hline & 36 & 80.02 & $\overline{70.66}$ & 31.8 & 1262 & 10.06 & 22.10 & 0.30 & 61.64 & 182 & $\overline{08 \mathrm{C}}$ & 2766 & 12.8 & 224 & 7.33 & 10.18 \\
\hline & 37 & 104.12 & 78.35 & 15.68 & 10.2 & 19.53 & 12.23 & 8.49 & 125.70 & 128 & 1108 & 2884 & 3.74 & 73 & -9.33 & 5.48 \\
\hline & 30 & 95.68 & 83.96 & 20.36 & 18.64 & 19.96 & 23.35 & 11.92 & $121 . \mathrm{CO}$ & 106 & 1214 & 2990 & 1.43 & -3.39 & -1.32 & 1.72 \\
\hline & 39 & 74.59 & 73.33 & 20.15 & 1053 & 16.64 & 21.49 & 12.42 & 79.43 & 124 & 1330 & 3114 & 3.07 & -4.85 & -6.11 & 9.62 \\
\hline & 40 & 56.71 & 60.33 & 18.71 & 97 & 24.15 & 13.16 & 15.61 & 45.77 & 74 & 1412 & 3188 & $-2.4 E$ & 1099 & -14.45 & 9.01 \\
\hline & $4^{\prime}$ & 32.24 & 28.73 & 14.71 & 11.21 & 10.71 & 7.9 & 14.32 & 27.97 & 75 & 1487 & 3263 & -6.42 & 2.31 & 0.5 & 3.5 \\
\hline & 42 & 12.98 & 27.97 & 18.61 & 11.5 & 10.59 & 8.70 & 7.87 & $18.4 \mathrm{~J}$ & 40 & 1527 & 3303 & J.91 & 1.31 & 0.91 & 7.11 \\
\hline & 43 & 11.35 & 28.45 & 13.79 & 1291 & 12.46 & 15.64 & 11.79 & 22.72 & 38 & 1565 & 3341 & 3.85 & -3.18 & $0.4 E$ & 0.88 \\
\hline Buddarls & 44 & 51.44 & 50.37 & 27.15 & 3272 & 30.60 & 45.39 & 30.32 & FIO dalad & 319 & 315 & 3600 & 5.07 & -6.53 & -6.14 & -557 \\
\hline & 45 & 57.52 & 62.72 & 19.44 & 27.25 & 40.77 & 31.25 & 28.81 & ne data & 78 & 397 & 3738 & 244 & $9 . \overline{52}$ & -13.52 & -7.81 \\
\hline & 46 & 65.57 & 43.93 & 33.2 & 17.11 & 22.00 & 23.28 & 30.8 & no data & 394 & 791 & 4132 & -7.52 & -1.19 & -4.98 & 1E.09 \\
\hline & 47 & 39.84 & 28.35 & 24.21 & 1341 & 24.03 & 19.89 & 21.48 & no dalia & 138 & 925 & 4270 & $-1.5 \mathrm{~S}$ & 4.14 & -10.62 & 10.8 \\
\hline & 48 & 49.94 & 35.41 & 20.62 & 21.27 & 29.18 & 31.29 & 30.75 & no data & 59 & $98 \mathrm{E}$ & 4329 & 3.54 & -2.11 & -7.91 & -065 \\
\hline Camp & 1 & 69.51 & 68.88 & 60.45 & 26.29 & 28.55 & 21.72 & 17.6 & no data & 436 & $43 E$ & 4765 & 4.12 & 6.33 & -2.26 & 34.16 \\
\hline & 2 & 82.25 & 79.8 & 43.89 & 16.71 & 33.41 & 17.06 & 24.8 & no data & 103 & 535 & 4868 & -7.74 & 1635 & -16.7 & 27.18 \\
\hline & 3 & 59.41 & 47.94 & 62.78 & 14.64 & 21.49 & 10.48 & 20.31 & no data & 255 & 794 & 5123 & -9.83 & 1101 & -6.85 & $4 E .14$ \\
\hline
\end{tabular}




\begin{tabular}{|c|c|c|c|c|c|c|c|c|c|c|c|c|c|c|c|}
\hline \multirow[t]{4}{*}{ Plpes } & 4 & 63.13 & 61 & 5.6 & 1681 & 2321 & 867 & 0.86 & nc data & 1900 & 7116 & 7.79 & 14.54 & -6.4 & 34.79 \\
\hline & 5 & 6557 & 6.8 & 57.18 & 3911 & 31.87 & 24.85 & 3835 & ne data & 236 & 732 & -13.38 & 6.32 & 7.24 & 1807 \\
\hline & 6 & 584 & 5657 & 6604 & 5812 & 4004 & 17.93 & 37.97 & nc deta & 91 & 8273 & $-2 \mathrm{CD}$ & 2211 & 1806 & 6.92 \\
\hline & & & & & & & & & & & & & $1941-69$ & & \\
\hline \multirow[t]{2}{*}{ Incorstant } & $i$ & $40 \mathrm{tc}$ & 4884 & $2 / 9$ & 389 & 1981 & no data & 44.6 & nc data & $13 / 2$ & 9646 & & -24.54 & & \\
\hline & & & & & & & no data & & & & & & & & \\
\hline \multirow[t]{6}{*}{ Pencarroy } & 8 & 4010 & 48.45 & 38.9 & $5: 1$ & 46.44 & no data & 33.16 & nc data & 1025 & 10670 & & $132 \mathrm{c}$ & & \\
\hline & 9 & 66.11 & 67.73 & 4217 & 71.17 & 6201 & no data & 37.52 & nc data & 95 & 10765 & & 24.49 & & \\
\hline & 10 & bost & $9 / .44$ & dob4 & yyte & 9341 & no data & $\mathrm{b} .01$ & nc data & 126 & 106010 & & $2 b 4$ & & \\
\hline & 11 & SODS & 9821 & 7949 & 10258 & 9.77 & no data & 50,47 & nc data & 123 & $1101 \%$ & & 35.3 & & \\
\hline & 12 & 6300 & 79.16 & 4696 & 5966 & 569 & no data & 42 & nc data & 110 & $1112 \%$ & & 14.9 & & \\
\hline & & & & & & & no data & & & & & & & & \\
\hline \multirow[t]{3}{*}{ K. Eay } & 13 & $132 / b$ & $12-69$ & 12.18 & no date & 133.66 & no data & $r 34 r$ & nc data & b1/ & 11640 & & BULE & & \\
\hline & 14 & 340.37 & 36.32 & 330.28 & no data & 347.18 & no dota & 24817 & nc data & 149 & 11789 & & 9001 & & \\
\hline & 15 & 150.29 & 146.54 & 146.06 & no date & 146.96 & no data & 57.44 & nc data & 178 & 11567 & & 89.62 & & \\
\hline
\end{tabular}




\begin{tabular}{|c|c|c|c|c|c|c|c|c|c|c|c|c|c|c|c|}
\hline & & Width char & ate $n / y$ & & & & & & & Wisth chan & te $m$ 'yr & & & & \\
\hline Locat on & profile & \begin{tabular}{|l|l|} 
\\
\end{tabular} & 15 & 6 & 10 & 16 & 7 & Location & profile & 13 & 10 & o & 10 & 10 & \\
\hline$\overline{\text { Days Bay }}$ & 1 & 0.37 & 0.23 & 0.71 & -0.33 & -0.81 & 0.66 & Rokinson & 20 & 212 & o.c6 & 1.40 & -0.00 & $0.5 \mathrm{~A}$ & 0.80 \\
\hline & 2 & 0.33 & 0.28 & D.67 & $-0.4^{4}$ & -0.66 & 0.76 & & 21 & 2.23 & 0.40 & 0.00 & 0.43 & 0.92 & 0.31 \\
\hline & 3 & 0.4 & 0.08 & 0.96 & -0.55 & -0.57 & 0.55 & & 22 & 1.94 & 0.57 & 0.23 & 0.12 & “.46 & 0.20 \\
\hline & 4 & $0 .{ }^{2} 5$ & -0.21 & -0.32 & -0.17 & -0.67 & 1.37 & & 23 & 1.72 & 0.92 & -0.09 & 0.60 & .27 & 0.21 \\
\hline
\end{tabular}


Appendix 3: Grainsize Data 
Grainsize Data
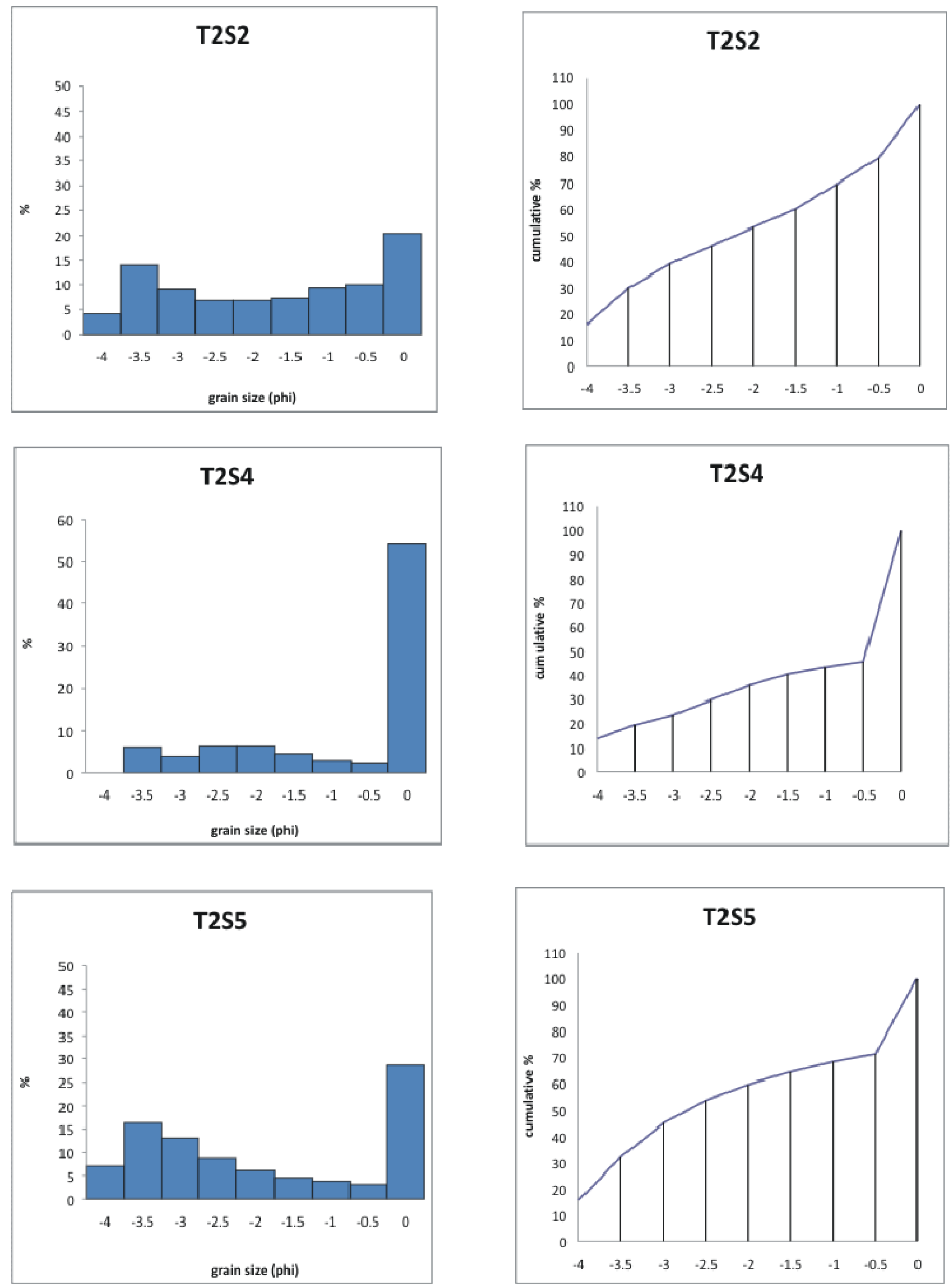

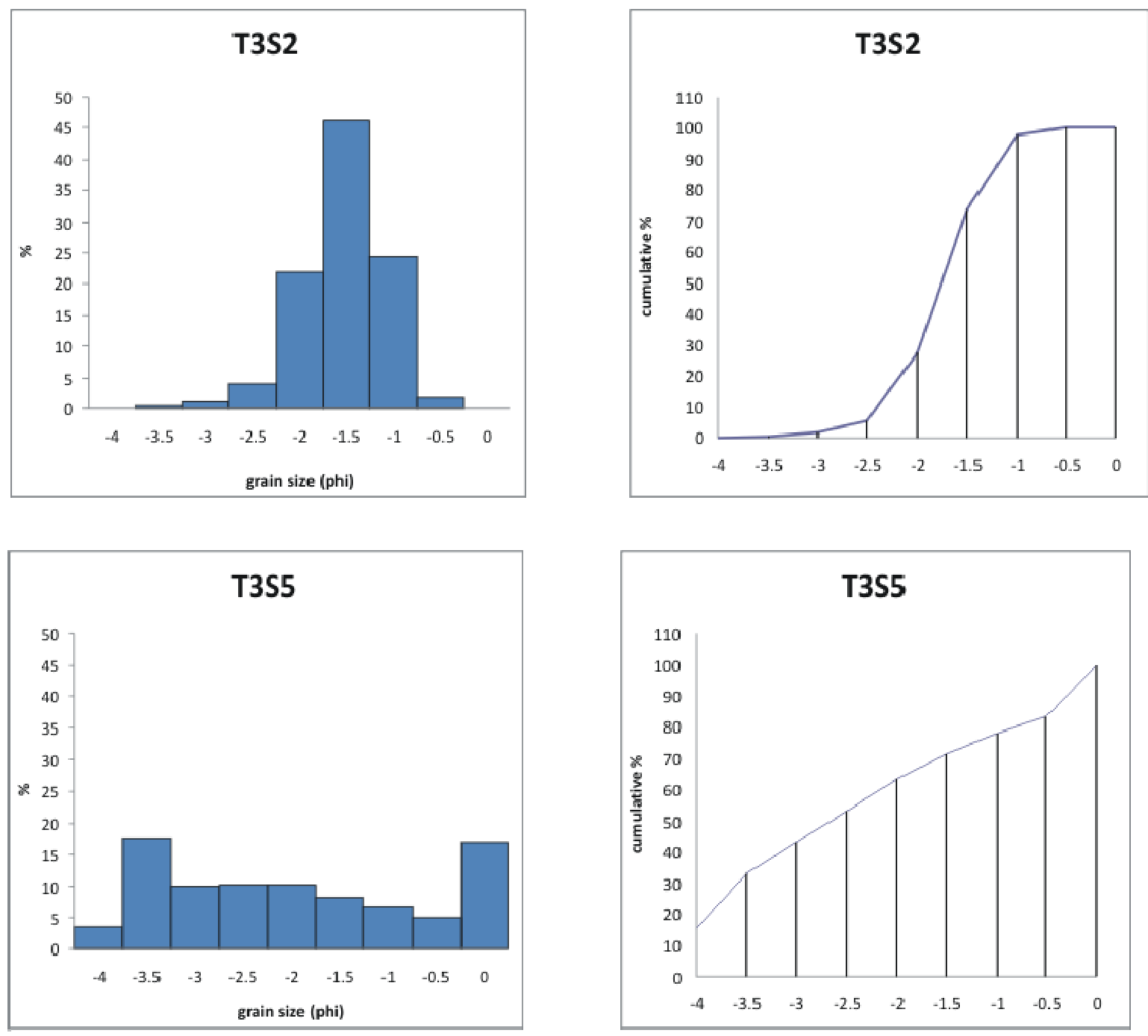

T4S1 coarse
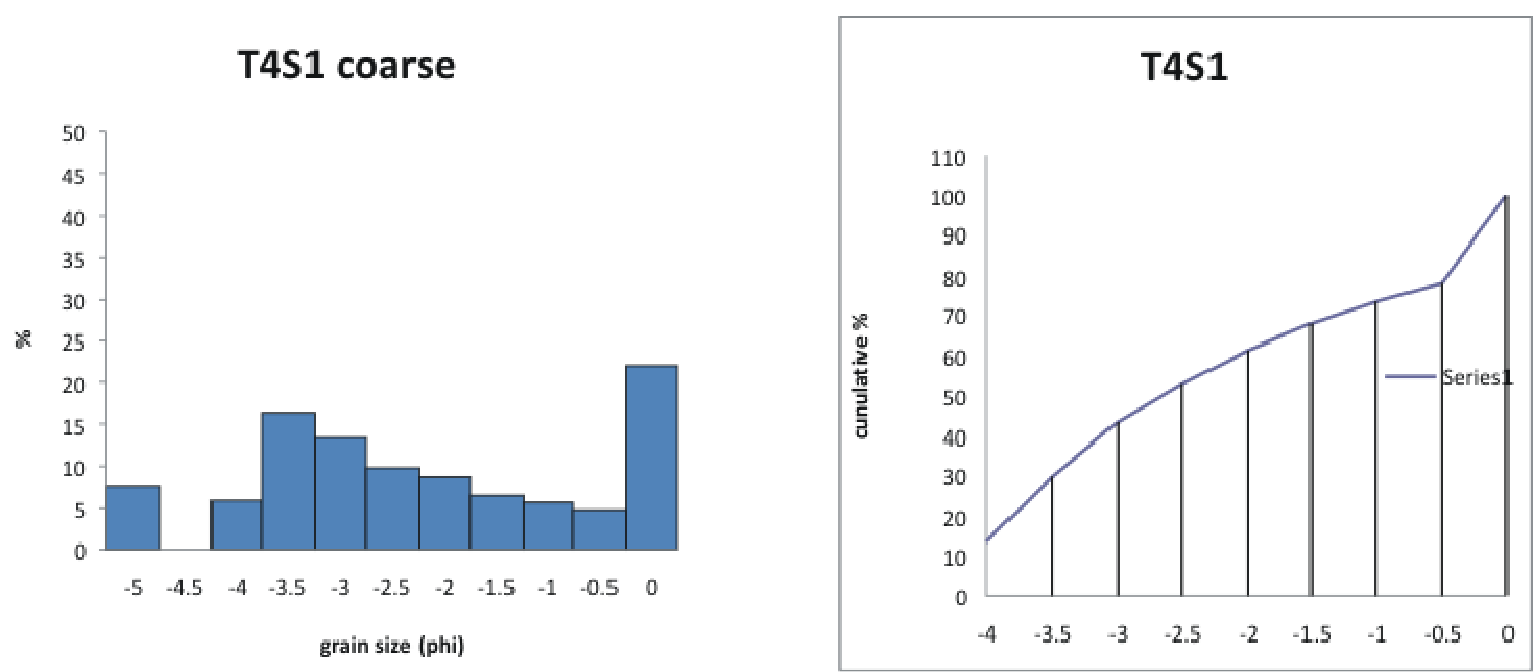
T4S2
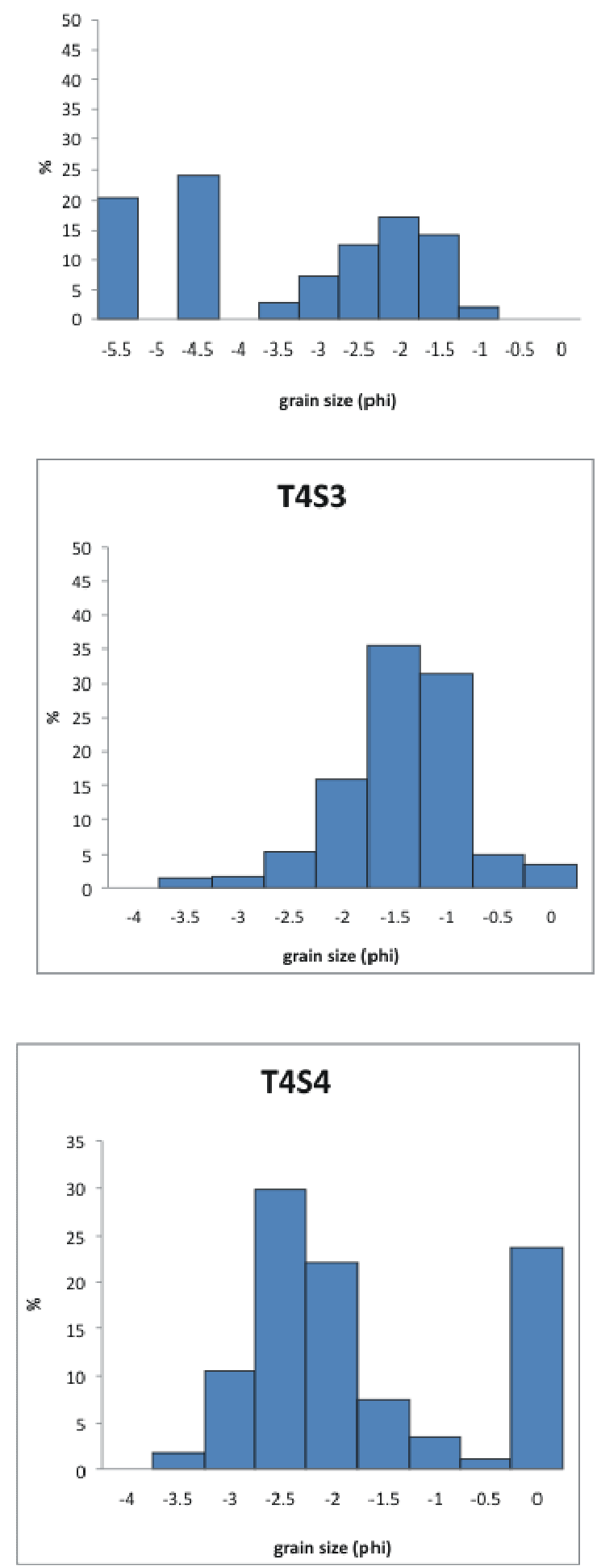

T4S2

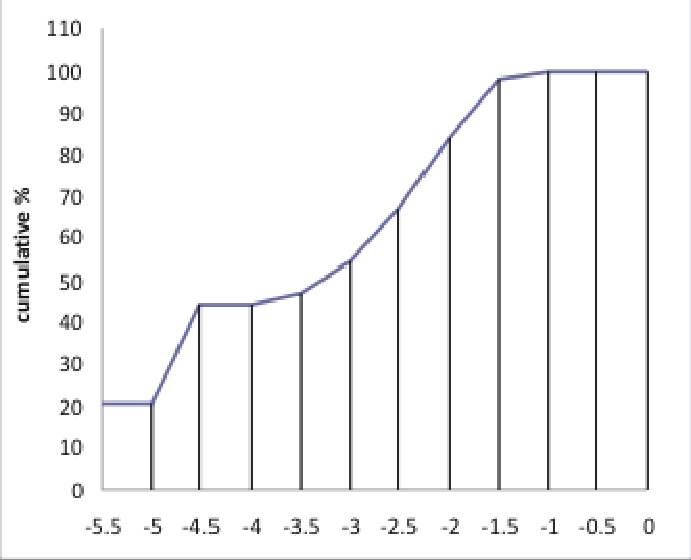

T4S3

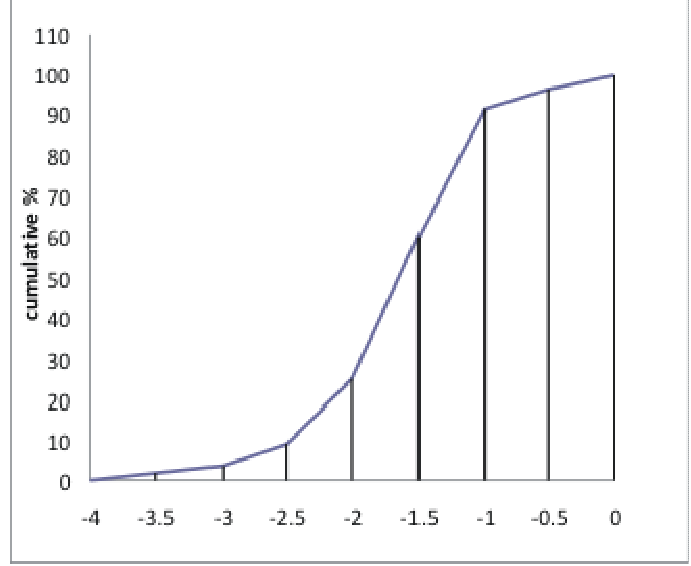

T4S4

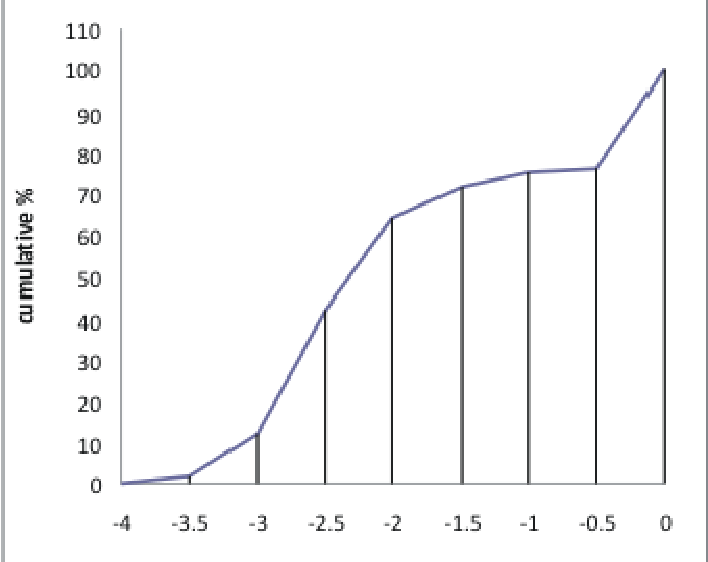




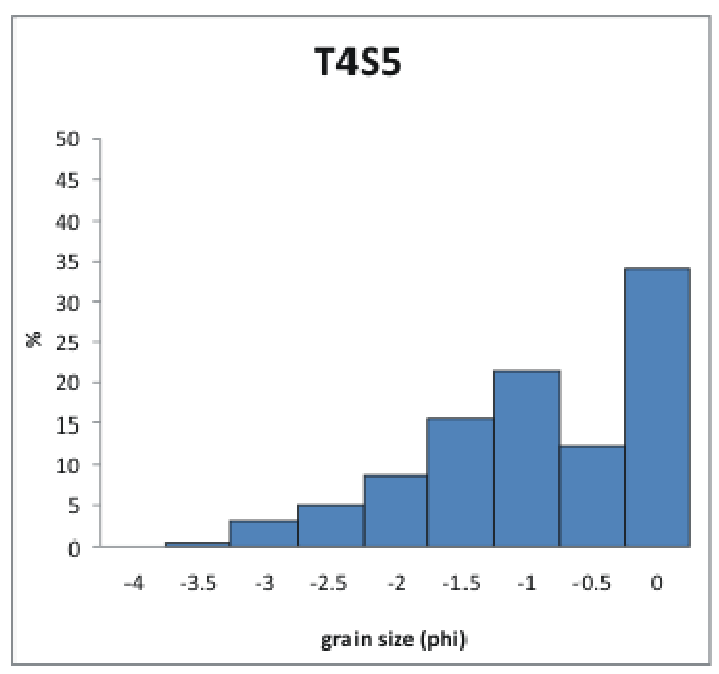

T5S2 coarse
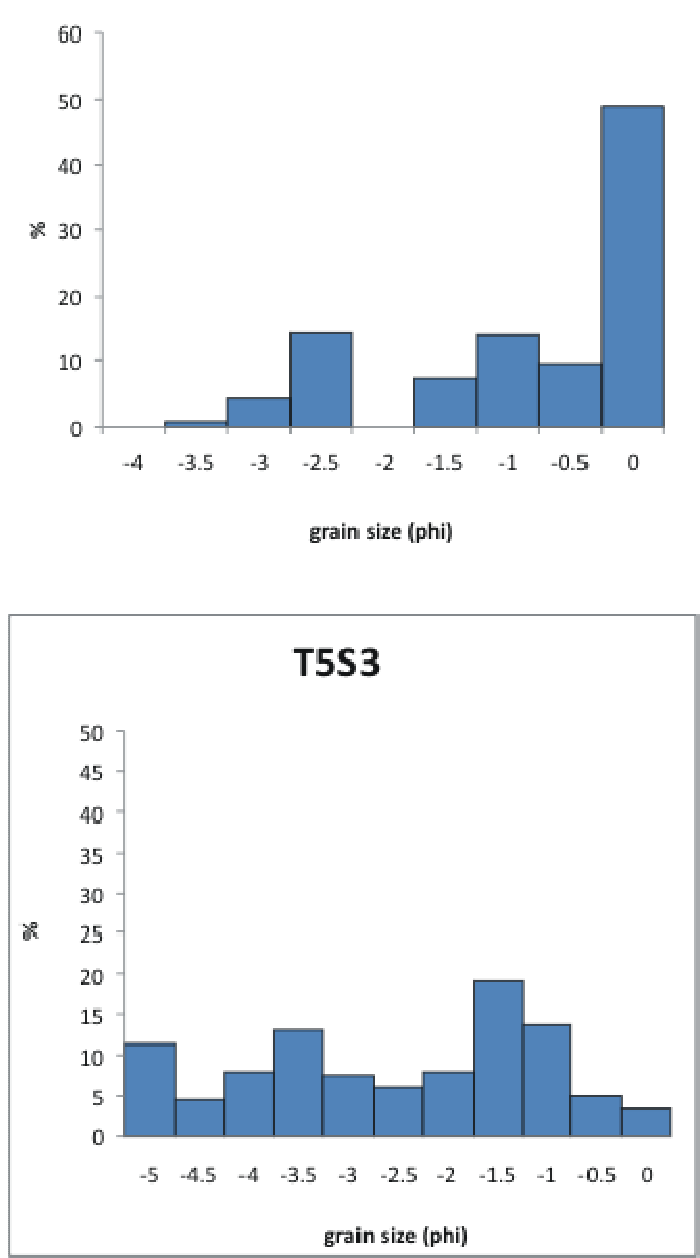

T4S5
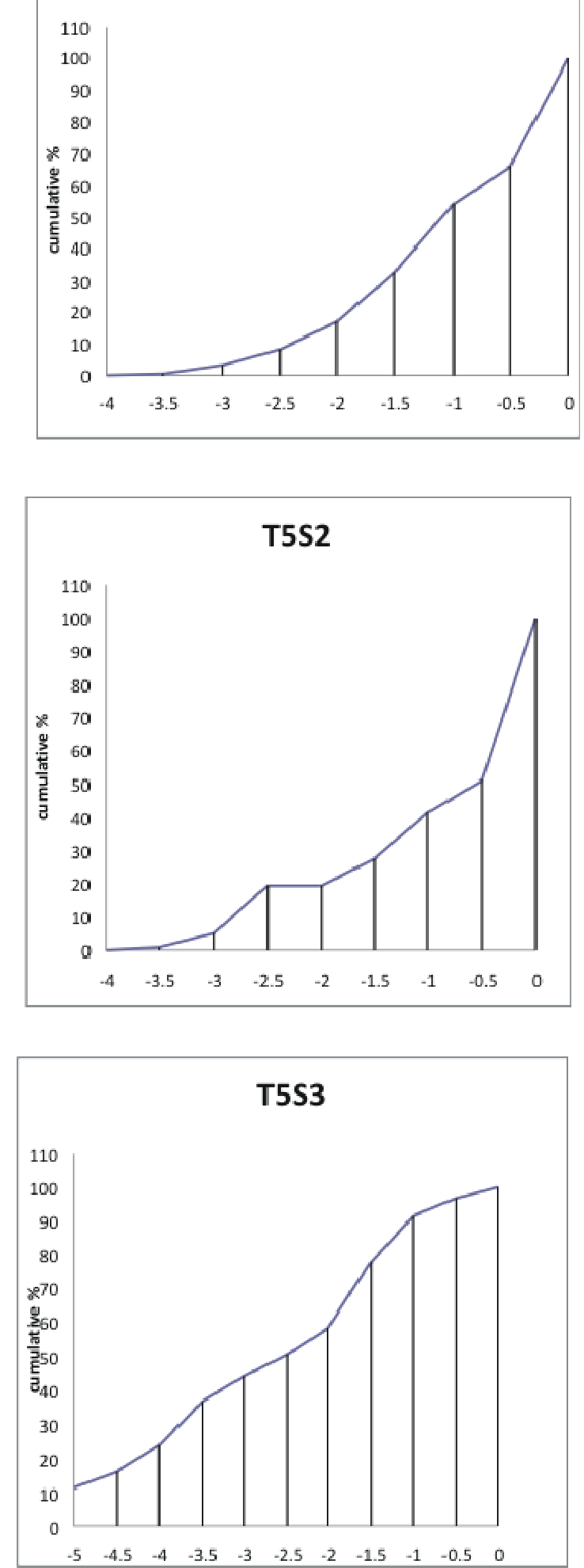

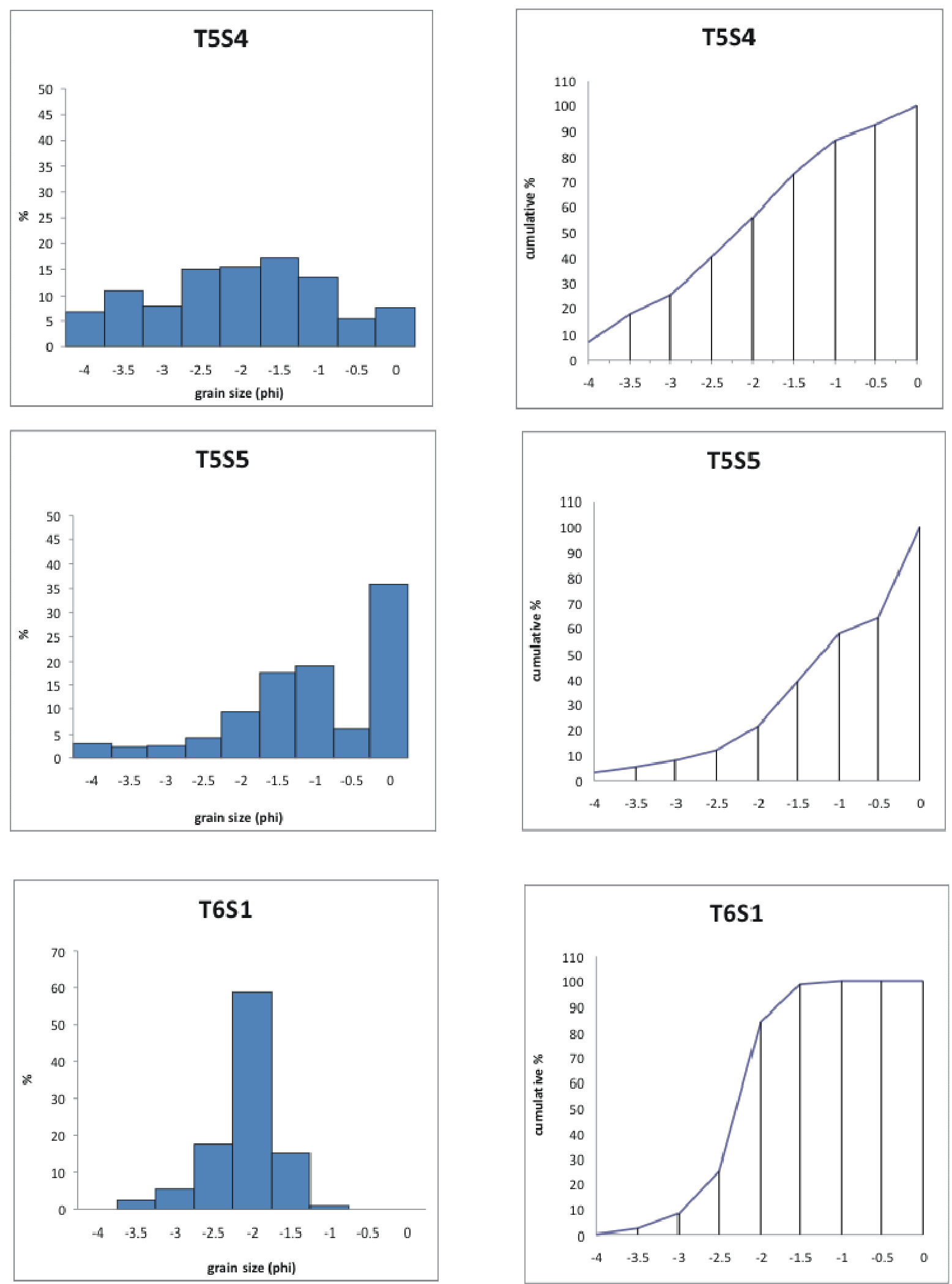

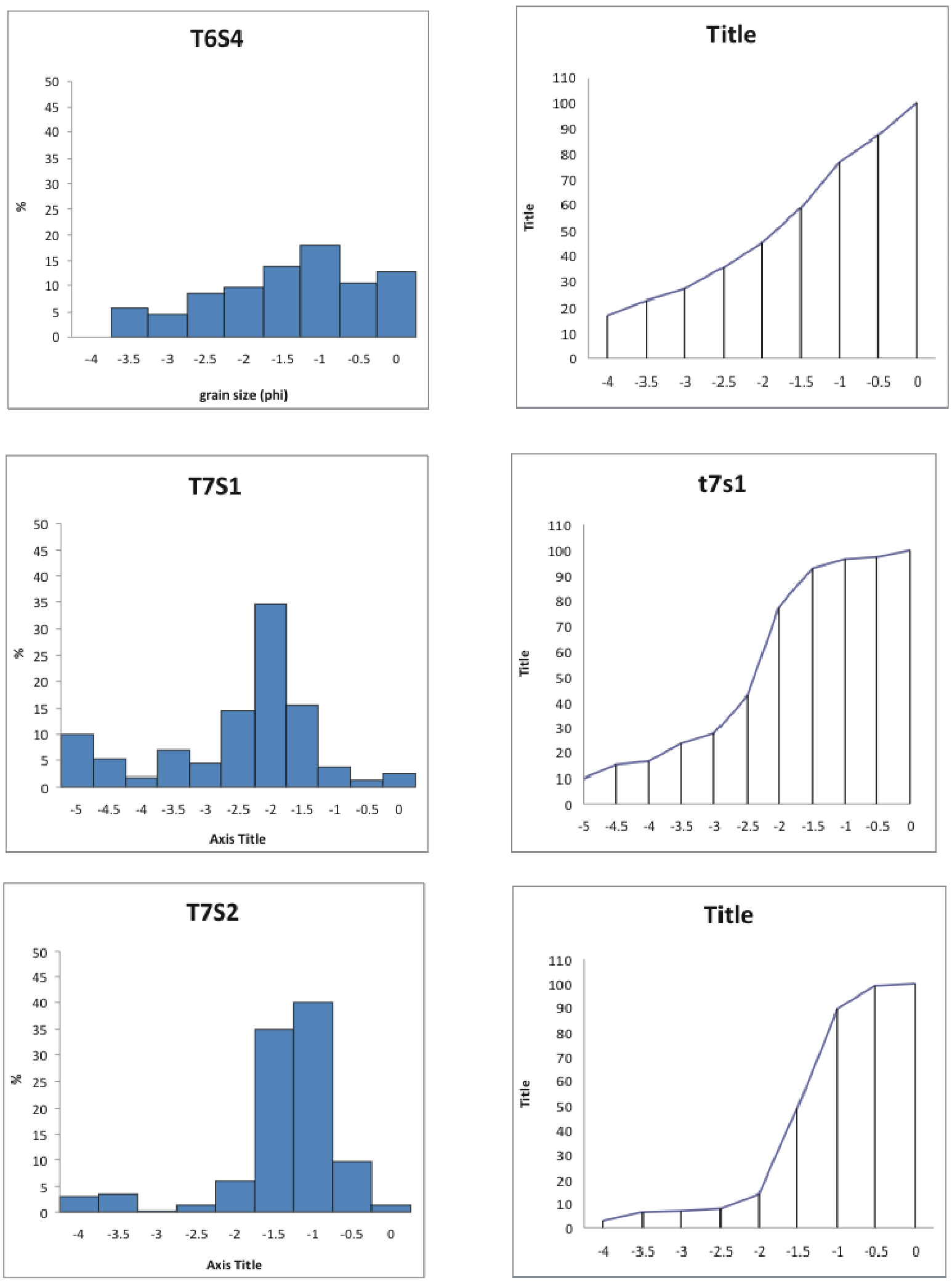

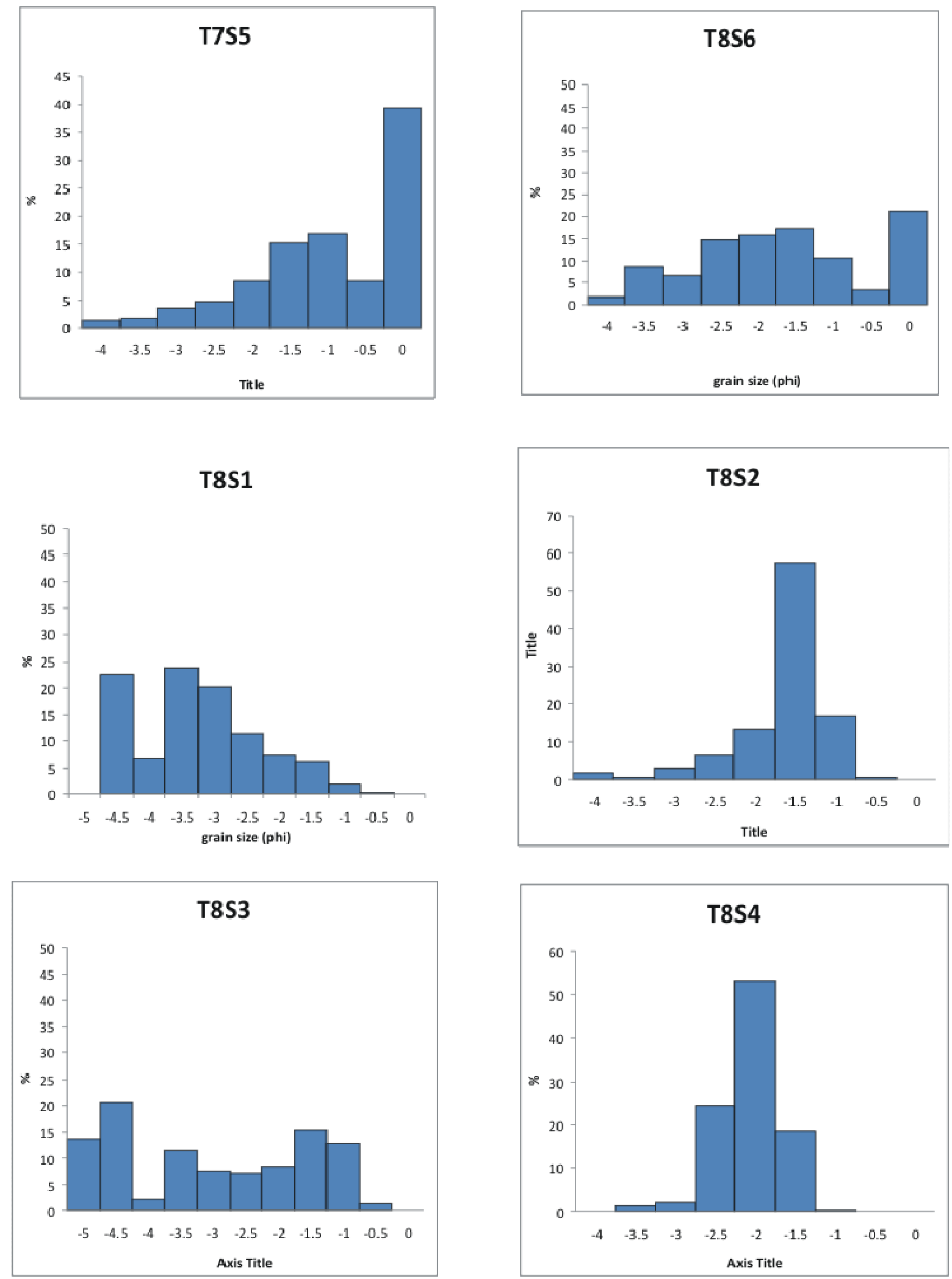

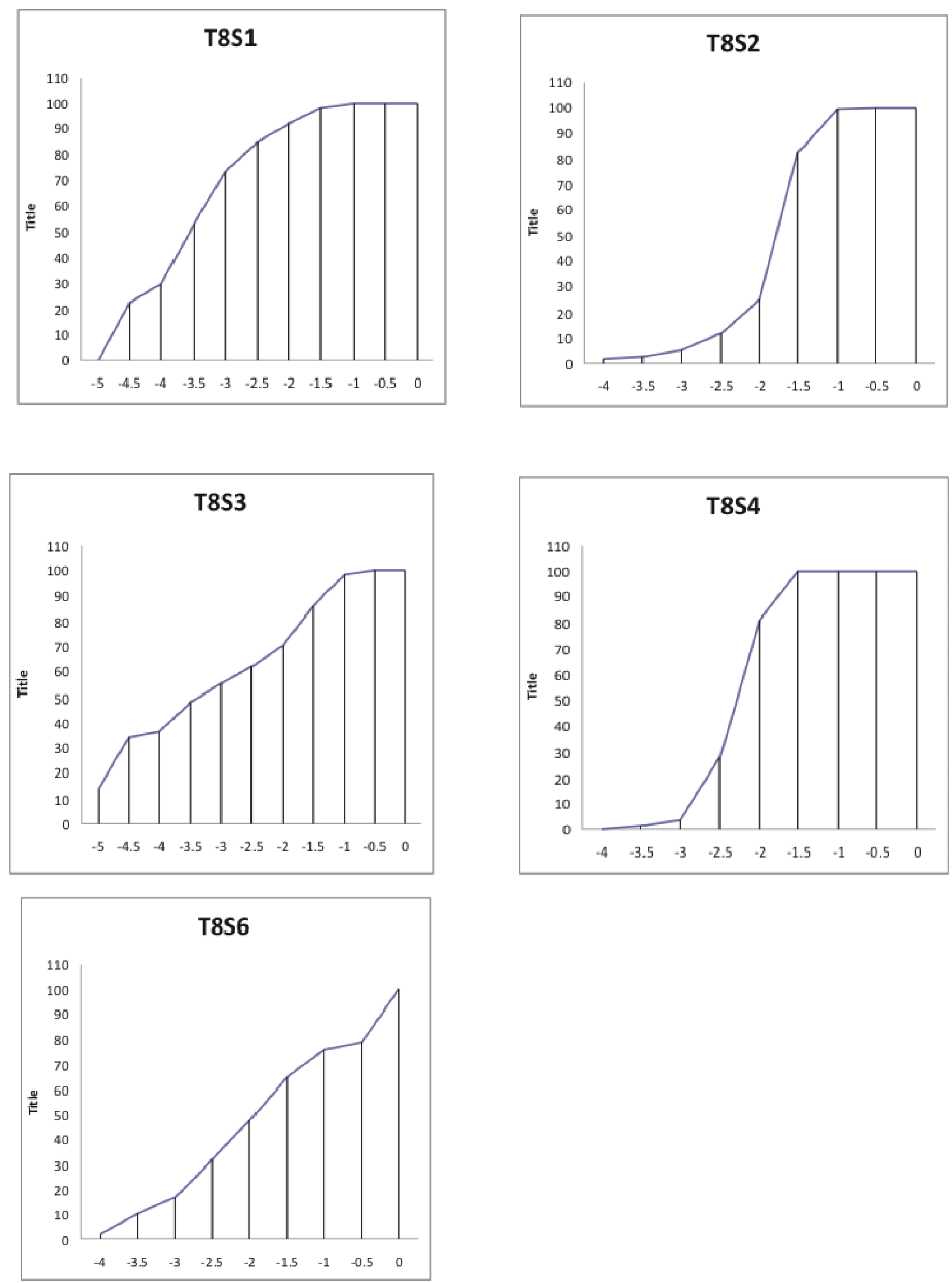

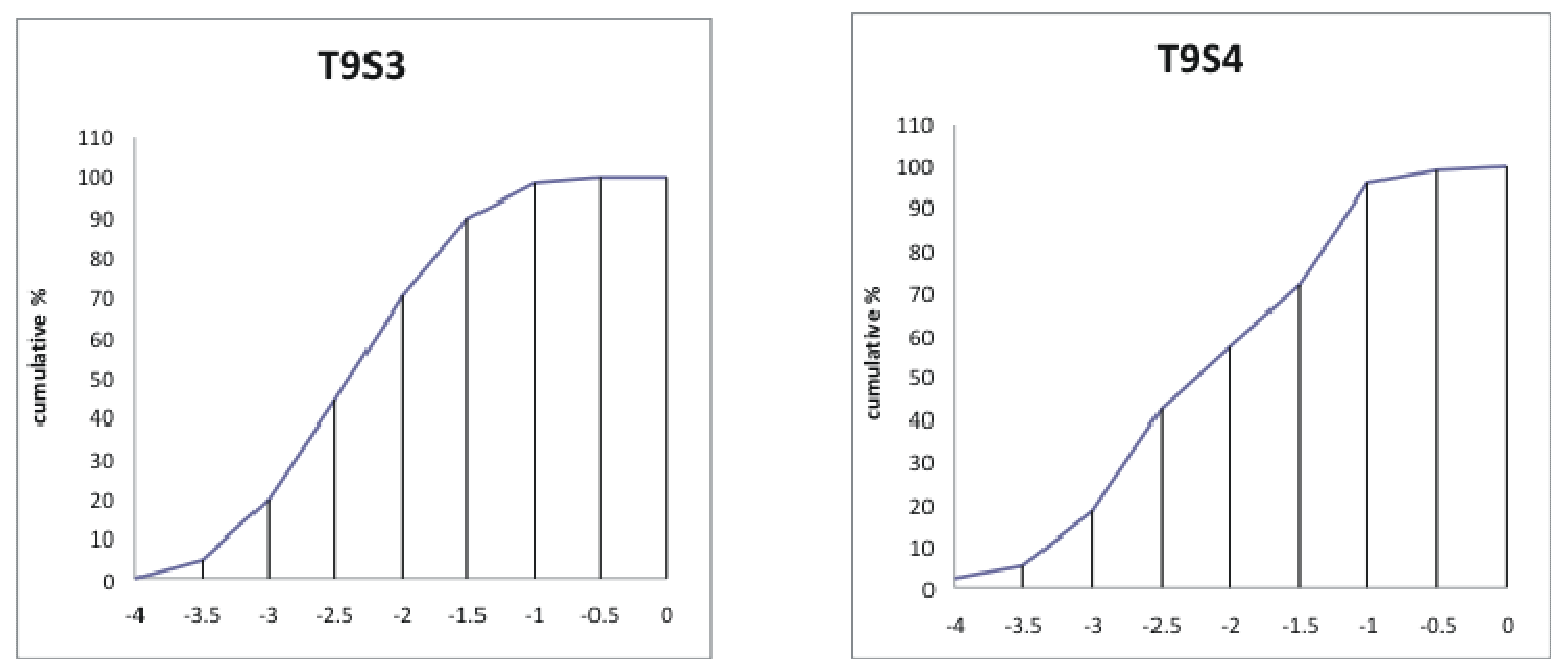